JANAINA SCHOENMAKER

\title{
CONTROLE DAS PARCERIAS \\ ENTRE O ESTADO E O TERCEIRO SETOR PELOS TRIBUNAIS DE CONTAS
}

DISSERTAÇÃO DE MESTRADO

ORIENTADORA: PROFESSORA DOUTORA ODETE MEDAUAR

FACULDADE DE DIREITO DA USP

SÃO PAULO

2009 
Janaina Schoenmaker

CONTROLE DAS PARCERIAS

ENTRE O ESTADO E O TERCEIRO SETOR PELOS TRIBUNAIS DE CONTAS

Dissertação de Mestrado, apresentada à Faculdade de Direito da Universidade de São Paulo, como requisito parcial à obtenção do título de mestre em Direito, na área de concentração Direito do Estado.

Orientadora: Professora Doutora Titular de Direito Administrativo Odete Medauar

Faculdade de Direito da USP

São Paulo

2009 
BANCA EXAMINADORA 


\section{AGRADECIMENTOS}

A elaboração de um trabalho sempre contará com o incentivo de inúmeras pessoas.

Reconhecendo o imenso apoio recebido sob as mais diversas formas e em cada uma das etapas para confecção desta dissertação, quero registrar minha gratidão a muitas pessoas, dentre elas:

Ao Leonardo Fernandes Giglio, meus pais e minhas irmãs, pelo apoio incondicional;

Àqueles sem os quais este sonho dificilmente se concretizaria: Vera Monteiro, Gustavo Justino de Oliveira, Luis Manuel Fonseca Pires e Léo Leoncy.

A todos com os quais pude contar e que me auxiliaram de forma desprendida, direta ou indiretamente: Celso Fernandes Campilongo, Rodrigo Pagani de Souza, Isabel Monteiro, Gabriela Szelest Peres Balbino, Cássia Rangel Monteiro Cascione, Lucas Cherem Camargo Rodrigues, Silvana de Rose, Everton Natal dos Santos, Ana Lucia Mazzucca Drabovicz, Silvana Macedo, Rosane Meira de Menezes, Natasha Schmitt Caccia Salinas, Paulo Henrique Quintana e Márcia Pelegrini.

Aos integrantes da banca de qualificação, pelas preciosas críticas e sugestões,

À inspiradora, dedicada e respeitosa orientadora, Odete Medauar, com eterna gratidão. 
"Se o controle tem custo, a falta de controle tem custo muito maior. $O$ que se investe na fiscalização não é despesa, mas antes, economia".

1 BRASIL. TCU. Acórdão n. 402, de 11 de março de 2009 - Plenário. Min. Relator José Jorge. Disponível em: http://www.tcu.gov.br. Acesso em: 28 jul. 2009. 


\section{RESUMO}

SCHOENMAKER, J. Controle das Parcerias entre o Estado e o Terceiro Setor pelos Tribunais de Contas. 2009. 204f. Dissertação (Mestrado). Faculdade de Direito, Universidade de São Paulo, São Paulo, 2009.

O escopo do presente trabalho consiste em examinar o controle pelos Tribunais de Contas sobre as parcerias celebradas entre o Estado e as entidades do terceiro setor envolvendo a gestão de recursos públicos. Procurou-se contextualizar o tema, abordando as novas facetas do Estado e a Administração Pública Consensual, bem como se apresentou noção de terceiro setor e suas atividades para fins de parceria. Abordou-se o fomento estatal, as espécies de transferências voluntárias de recursos públicos e os instrumentos de parceria, como convênios, contratos de repasse e de gestão e termos de parceria. Introduzindo-se a questão do controle pelos Tribunais de Contas das parcerias celebradas entre o Estado e o terceiro setor, foram examinados os seus fundamentos. Ainda, foram verificados os tipos de fiscalização, seus aspectos e as competências constitucionais do Tribunal de Contas da União aplicáveis sobre elas. Após, foram analisadas as iniciativas para o desencadeamento do controle e os momentos de incidência, examinando-se a legislação específica. $\mathrm{O}$ procedimento para a operacionalização do controle foi abordado sob a ótica do exercício das competências dos Tribunais de Contas sobre as citadas parcerias e organizações. Por fim, abordaram-se os efeitos diretos e indiretos das decisões dos referidos Tribunais sobre as entidades do terceiro setor e seus dirigentes, dentre elas as medidas cautelares e as sanções.

Palavras-chave: Administração Pública Consensual. Parcerias. Terceiro Setor. Transferência de Recursos Públicos. Controle. Tribunal de Contas. 


\begin{abstract}
SCHOENMAKER, J. Control by the Audit Courts of Partnerships involving the Government and the Third Sector. 2009. 204p. Dissertation (Masters Degree). Faculdade de Direito, Universidade de São Paulo, São Paulo, 2009.

The scope of the present dissertation concerns scrutinizing the control by the Audit Courts of the partnerships involving the State and third sector organizations, including the management of public funds. This paper has aimed to contextualize the subject, observing the new features of the State and the Consensual Public Administration. It has also sought to present the notion of third sector and its possible role in partnership purposes. Besides, it has approached the government fomentation, the types of voluntary transferences of public resources and the partnership instruments such as agreements, transfer contracts, management contracts and partnership commitments. Regarding the control by the Audit Courts of partnerships involving the third sector, its fundaments have been investigated. Additionally, the variety of inspection possibilities was verified, as well as its aspects and the constitutional competencies of the Brazilian Court Audit. Then, the initiatives for unleashing the control and the moments of incidence were analyzed, being the specific legislation considered. The procedure to enable this control was approached from the standpoint of the Audit Courts' competencies over the abovementioned partnerships and organizations. Eventually, the direct and indirect effects of the decisions of the referred Courts over the third sector organizations and their managers were analyzed by the author, including the provisional measures and the applicable punishment.
\end{abstract}

Keywords: Consensual Public Administration. Partnerships. Third Sector. Transference of Public Funds. Control. Audit Courts. 


\section{SUMÁRIO}

RESUMO

ABSTRACT

1 ESTADO CONSENSUAL E TERCEIRO SETOR

1.1 A Reforma do Estado e a Administração Pública Consensual

1.2 Terceiro setor

1.2.1 Noção de terceiro setor

1.2.2 Atividades do terceiro setor para fins de parceria com o Estado

1.2.2.1 Atividades do terceiro setor

1.2.2.2 Natureza da atividade e da relação com o Poder Público

2 OS VÍNCULOS FORMAIS DE PARCERIA ENTRE ESTADO E TERCEIRO SETOR

2.1 Atividade Estatal de Fomento

2.1.1 As transferências voluntárias de recursos públicos

2.1.1.1 Subvenção

2.1.1.2 Auxílio

2.1.1.3 Contribuição

2.1.2 Os instrumentos de parceria

2.1.2.1 Convênio

2.1.2.2 Contrato de repasse

2.1.2.3 Contrato de gestão

2.1.2.4 Termo de parceria

3 TRIBUNAL DE CONTAS E TERCEIRO SETOR: FUNDAMENTOS DO CONTROLE

3.1 Os fundamentos do controle do terceiro setor pelos Tribunais de Contas

3.2 Introdução às competências do Tribunal de Contas da União

4 TIPOS E ASPECTOS DA FISCALIZAÇÃO

4.1 Tipos de Fiscalização

4.1.1 Fiscalização contábil

4.1.2 Fiscalização operacional

4.1.3 Fiscalização patrimonial

4.1.4 Fiscalização financeira

4.1.5 Fiscalização orçamentária

4.2 Aspectos da fiscalização

4.2.1 Legalidade 
4.2.2 Legitimidade

4.2.3 Economicidade

4.3 Renúncia de receita e aplicação de subvenções

5 COMPETÊNCIAS CONSTITUCIONAIS DE CONTROLE

5.1 Competências constitucionais de controle incidente sobre o terceiro setor

5.1.1 Julgar prestação de contas

5.1.1.1 Considerações iniciais

5.1.1.2 Controvérsias sobre a competência para julgamento das contas
a) Incompetência
b) Competência direta
c) Do posicionamento intermediário à competência indireta
d) Considerações finais

5.1.2 Fiscalizar admissão de pessoal

5.1.3 Realizar inspeções e auditorias

5.1.4 Fiscalizar recursos repassados pela União

5.1.5 Aplicar sanções e determinar prazo para adoção de medidas

5.1.6 Sustar atos impugnados e representar

6 OPERACIONALIZAÇÃO DO CONTROLE

6.1 Classificação quanto ao controle

6.1.1 Quanto à iniciativa para se desencadear

6.1.1.1 Controle mediante provocação

6.1.1.2 Controle de ofício

6.1.2 Quanto ao momento

6.1.2.1 Controle prévio
a) Convênio e Contrato de Repasse
b) Termo de Parceria
c) Contrato de Gestão

6.1.2.2 Controle concomitante
a) Convênio e Contrato de Repasse
b) Termo de Parceria
c) Contrato de Gestão

6.1.2.3 Controle sucessivo ou a posteriori
a) Convênio e Contrato de Repasse
b) Termo de Parceria
c) Contrato de Gestão 
6.2.1 Fiscalização

6.2.1.1 Levantamento, auditoria, inspeção, acompanhamento e monitoramento

6.2.2 Processos de Tomada ou Prestação de Contas

6.2.3 Tomada de Contas Especial

6.2.4 Procedimentos especiais

6.2.4.1 Denúncia e consulta

7 EFEITOS DO CONTROLE

7. 1 Considerações preliminares

7.2 Efeitos diretos

7.2.1 Medidas cautelares

7.2.1.1 Aplicabilidade

7.2.1.2 Natureza

7.2.1.3 Suspensão de atos

7.2.1.4 Afastamento temporário

7.2.1.5 Indisponibilidade de bens

7.2.1.6 Arresto de bens

7.2.2 Sanções

7.2.2.1 Aplicabilidade

7.2.2.2 Multa

7.2.2.3 Inabilitação

7.2.2.4 Inidoneidade

7.2.2.5 Procedimento de aplicação de sanção decorrente de julgamento pela irregularidade de contas

7.2.2.6 Responsabilidade pessoal do agente e/ou da entidade privada

7.2.3 Condenação comportamental

7.2.4 Inscrição no CADIRREG e no CADIN

7.3 Efeitos indiretos

7.3.1 Inelegibilidade

7.3.2 Impedimento para celebração de parcerias e recebimento de recursos públicos

7.3.3 Propositura de processo criminal

7.3.4 Propositura de ação de cobrança

7.3.5 Declaração de Improbidade Administrativa

7.3.6 Efeitos indiretos diversos 
CONTROLE DAS PARCERIAS

ENTRE O ESTADO E O TERCEIRO SETOR PELOS TRIBUNAIS DE CONTAS

1 ESTADO CONSENSUAL E TERCEIRO SETOR

\subsection{A Reforma do Estado e a Administração Pública Consensual}

A questão central do presente trabalho - o controle pelos Tribunais de Contas das parcerias $^{2}$ celebradas entre o Estado e as entidades do terceiro setor ${ }^{3}$ - recebeu maior atenção durante e após a denominada "crise do Estado"4 e sua "Reforma", fenômenos que redundaram em questionamentos quanto à "noção de Estado, suas dimensões ideais e suas relações com a sociedade" ${ }^{5}$, bem como em alterações no Direito Público ${ }^{6}$ - Constitucional e Administrativo ${ }^{7}$ no Brasil e em vários países.

2 As parcerias a serem examinadas restringem-se àquelas que envolvem transferência de recursos públicos do Estado para o terceiro setor, circunstância que justifica a sujeição deste ao controle exercido pelos Tribunais de Contas. Na exposição de motivos do anteprojeto de Lei Orgânica da Administração Pública Federal, defendese que algumas entidades privadas que desenvolvem atividades de interesse público estão por isso habilitadas a atuar em parceria (nele abarcadas sob o nome de contrato público de colaboração, independentemente da nomenclatura adotada em legislação específica) com o Estado, quando podem passar a gerir verbas públicas. Estarão então sujeitas, sob alguns aspectos, às normas de direito público. No citado instrumento, optou-se por definir como entidades de colaboração aquelas integrantes do terceiro setor.

3 Em que pese o foco da presente dissertação estar no controle das parcerias, serão necessariamente abordadas questões relativas à fiscalização pelas Cortes de Contas das entidades do terceiro setor, seus fundamentos, competências e legislação aplicável, entre outras.

4 Há quem considere que a crise do Estado possui três facetas: a fiscal, a do modo de intervenção do Estado e a do modelo burocrático de gestão pública, o que se teria buscado solucionar, respectivamente, com "reformas econômicas orientadas para o mercado", reformas neoliberais e com a adoção de "um paradigma gerencial" com ênfase na eficiência, na orientação por resultados, na responsabilização e na flexibilização. Valéria Maria Trezza. O termo de parceria como instrumento de relação público/privada sem fins lucrativos: o difícil equilíbrio entre flexibilidade e controle. 2007. 198 f. Dissertação (Mestrado em Administração Pública e Governo - Escola de Administração de Empresas de São Paulo, Fundação Getúlio Vargas, São Paulo, 2007. p. 22) Disponível em: http://virtualbib.fgv.br/dspace/handle/10438/2406. Acesso em: jul. 2009.

${ }^{5}$ Regina Helena Machado. Reforma do Estado ou Reforma da Constituição? Rio de Janeiro: Lumens Júris, 2001, p. 104.

${ }^{6}$ Sabino Cassese. La arena pública: nuevos paradigmas para el Estado. In: La Crisis del Estado. Buenos Aires: Abeledo-Perrot, 2003. p. 101-106. 
Eis as razões pela quais figura importante versar a respeito de tais transformações neste tópico introdutório, a título de contextualização do escopo da presente dissertação.

Ultrapassada a predominância das concepções denominadas "Estado Mínimo" e "Estado do Bem-Estar Social”, ocorreram alterações em algumas características do Estado ${ }^{8}$ a partir da segunda metade do século XX, quando a doutrina passou a denominá-lo: Estado regulador, Estado subsidiário, Estado controlador, Estado ativador, Estado animador, Estado incitador, Estado catalisador, Estado mediador ${ }^{9}$, Estado reflexivo, Estado cooperativo, Estado contratante, Estado negociador, Estado-rede ${ }^{10}$, Estado consensual ${ }^{11}$ entre outras expressões pelas quais se buscou captar algum aspecto relevante do fenômeno estatal.

Pierre Rosanvallon ${ }^{12}$, prevendo a superação do Estado-providência, referiu-se à póssocial-democracia, propondo, como sua base, a redução, de modo não regressivo, das

Para Caio Tácito, as alterações do Direito Público são decorrentes da maior ou menor atuação do Estado (A reforma do Estado e a modernidade administrativa. Revista de Direito Administrativo, Rio de Janeiro, n. 215 , jan./mar. 1999, p.1).

${ }^{7}$ Conforme Regina Helena Machado. Reforma do Estado ou Reforma da Constituição? (cit.), p. 118-119, “[...] paralelamente às mudanças na ordem econômica, vem se transformando a ordem jurídico-institucional, cabendo ressaltar a gradativa transformação do dogma da teoria clássica do Estado, de separação de poderes da República, levados a assumir funções que não lhes eram tradicionalmente típicas".

Observa Odete Medauar, ademais, que surgem no vocábulo jurídico, termos nunca ou pouco usados até então, bem como assimilação pelo direito constitucional e administrativo de palavras de uso frequente em outras searas do Direito, como é o caso da expressão "regulação" (Regulação e Auto Regulação, Revista de Direito Administrativo, Rio de Janeiro, n. 228, p. 123-124, abr./jun. 2002)

8 A despeito de a Reforma do Estado restar mais evidente nos países nos quais se vivenciou efetivamente o Estado Liberal e o Estado Social, no Brasil também é possível perceber algumas alterações - sobretudo legislativas. De todo modo, conforme esclarece Gustavo Justino de Oliveira,“(...) revela-se extremamente difícil identificar um modelo estatal específico e unificador de todas as organizações políticas desde o início do século". (Parceria Público-Privada e Direito ao Desenvolvimento: uma abordagem necessária. Revista Eletrônica de Direito Administrativo Econômico, Salvador, n. 3, p. 1-28, ago./out. 2005b. Disponível em: <http://www.direitodoestado.com/revista/REDAE-3AGOSTO-2005-GUSTAVO\%20JUSTINO.pdf>. Acesso em: 28 jul. 2009.

9 Expressão utilizada por Gustavo Justino de Oliveira. (Governança Pública e Parcerias do Estado: a relevância dos acordos administrativos para a nova gestão pública. Revista Âmbito Jurídico, Rio Grande, n. 58, out. 2008 b. Disponível $\quad$ em: $\quad<$ http://www.ambitojuridico.com.br/site/index.php?n_link=revista_artigos_leitura\&artigo_id=5177>. Acesso em: 28 jul. 2009.), bem como por Jean-Pierre Gaudin (Gouverner par contrat: l'action publique en question. Paris: Presses de Sciences Politiques, 1999, p. 213).

${ }^{10}$ Conforme elencado por Odete Medauar. (O Direito Administrativo em Evolução. 2. ed. rev. atual. e ampl. São Paulo: Revista dos Tribunais, 2003, p. 93)

${ }^{11}$ Expressão usada por Marcos Maurício Toba. (Novos Parâmetros de Atuação da Administração Pública. 2003. 184 f. Tese (Doutorado em Direito Administrativo) - Faculdade de Direito, Universidade de São Paulo, 2003. p. 130).

${ }^{12}$ Pierre Rosanvallon, La crise de l'État-providence. 2. ed. Paris: Ed. Du Seuil, 1981, p. 130-133. 
demandas do Estado, pela transferência ${ }^{13}$ a entidades não estatais de alguns serviços públicos ${ }^{14}$ ou, simplesmente, serviços de interesse público.

A “diminuição do Estado" em face da crise, todavia, "não aponta para um Estado mais fraco, mas para um Estado mais forte, que recupere [...] a capacidade política de orientar a sociedade na direção do desenvolvimento e da democracia" ${ }^{\text {15 }}$. Para Roberto Dromi ${ }^{16}$, aquela diminuição não teria por fim negar suas responsabilidades ${ }^{17}$, a despeito de a gestão estatal passar a ser realizada cada vez mais subsidiariamente ${ }^{18}$ por meio de "novos modelos e formas jurídicas"19, deixando as atividades que não lhe são exclusivas a entes privados e públicos não-estatais ${ }^{20}$, quando as puderem desenvolver adequadamente. Assim, a administração seria pública" no sentido de não ser exclusivamente estatal ${ }^{21}$.

Segundo Gaspar Ariño Ortiz, do ponto de vista organizativo e institucional, o "Estado Contratual",22, "Consensual" ou "Estado Financiador",23, como novas feições do Estado

${ }^{13}$ Entende-se por 'transferência' em sentido lato, a que envolve a execução de serviços de interesse público por entes privados, sem redução da competência do Estado.

${ }^{14}$ Neste sentido, e em complemento ao acima citado, o autor assevera que, globalmente, esta alternativa à crise do Estado Providência se insere num triplo movimento: de redução da demanda do Estado, de solidariedade na sociedade e de produção de uma maior visibilidade social. Acrescentou, ainda, que reduzir a demanda do Estado e produzir a sociabilidade seguem em conjunto. A alternativa ao Estado Providência não decorre de uma ordem institucional, mas é principalmente social. Pierre Rosanvallon. La crise de l'État-providence. (cit.), 1981. p. 112 - tradução livre.

${ }^{15}$ Luiz Carlos Bresser Pereira. Sociedade Civil: sua democratização para a reforma do Estado. In: Luiz Carlos Bresser Pereira; Jorge Wilheim; Lourdes Sola (Org.). Sociedade e Estado em Transformação. São Paulo: UNESP, 1999, p. 75.

${ }^{16}$ Roberto Dromi. Modernización del Control Público. Madrid: Hispania Libros, 2005, p. 10. Tradução livre.

17 Segundo Gustavo Justino de Oliveira, “[...] mesmo diante da escassez de recursos públicos, o Estado não poderá isentar-se de suas responsabilidades nesse campo. A ele cumprirá promover uma série de outras ações (v.g. fomento, regulação, parcerias), as quais igualmente visam promover os valores fundamentais constitucionalmente consagrados". (Estatuto Jurídico do Terceiro setor e Desenvolvimento: conectividade essencial ao fortalecimento da cidadania, à luz dos 20 anos da constituição de 1988. In: CONGRESSO NACIONAL DO CONPEDI, 17., Brasília, DF, 2008a. Anais eletrônicos. Brasília, DF, 2008a. p. 1084-1109. Disponível em: http://www.conpedi.org/manaus/arquivos/anais/brasilia/10 169.pdf. Acesso em: 28 jul. 2009.)

${ }^{18}$ A subsidiariedade será objeto de análise ainda neste tópico.

19 Silvia Faber Torres. O Princípio da Subsidiariedade no Direito Público Contemporâneo. Rio de Janeiro: Renovar, 2001, p. 150.

20 “A palavra público é utilizada nesta expressão no sentido teleológico de toda atividade que alcança, afeta ou interessa a todos ou à maioria, e não no sentido de um determinado regime jurídico", na esteira de Paulo Modesto (Reforma administrativa e marco legal das organizações sociais no Brasil. Jus Navigandi, Teresina, ano 3, n. 30, abr. 1999. Disponível em: http://jus2.uol.com.br/doutrina/texto.asp?id=473. Acesso em: 06 mar. 2008. p. 8).

21 “Definitivamente, público e estatal não se identificam. Atualmente existem entidades que não são do Estado, mas que cumprem atividades idênticas às deste e se regulam primordialmente pelo direito público" - tradução livre. Roberto Dromi. Derecho Administrativo. 5. ed. Buenos Aires: Ciudad Argentina, 1996. p. 131.

22 “Assim, fala-se de uma das características mais importantes do Estado atual: sua condição de 'Estado contratual', apontando a utilização pelo Estado de organizações privadas, com ou sem fins lucrativos, para alcançar os seus fins públicos." (El retorno a lo privado: ante una nueva encrucijada histórica. In. Gaspar Ariño 
contemporâneo, substitui o antigo modelo de Estado administrativo-burocrático, hierárquico, unitário, centralizador e gestor direto por um novo tipo de Administração, gerencial, no qual uma multiplicidade de organizações, dentre elas as de natureza privada sem fins lucrativos, assume a gestão de serviços com a possibilidade de financiamento ${ }^{24}$ e controle de resultados pelo Estado ${ }^{25}$. Isto porque, ressalta Diogo de Figueiredo Moreira Neto, a "administração pública gerencial importa-se menos com os processos e mais com os resultados, para que sejam alcançados com o menor custo, no mais curto lapso de tempo e com a melhor qualidade possíveis" ${ }^{\prime 26}$.

Neste "novo modelo"27, que visa, dentre outros, a maior flexibilidade, descentralização, individualização das responsabilidades ${ }^{28}$, eficiência e economicidade ${ }^{29}$, destaca-se a direção no sentido da alteração da própria forma de gestão do Estado ${ }^{30}$, na qual a Administração busca substituir o mecanismo clássico da coerção pelo da colaboração, e da imperatividade $^{31}$ pela consensualidade ${ }^{32}$.

Ortiz (Org). Privatización y liberalización de servicios. Madrid: Universidad Autônoma de Madrid, 1999, p. 19-35. p. 26)

23 “(...) enfatiza a concepção do Estado financiador, concentrado na atividade de fomento, entendida como atividade de estímulo e pressão, realizada de modo não coativo, sobre os cidadãos e grupos sociais, para imprimir um determinado sentido a suas atuações. Para o autor, por meio de subvenções, isenções fiscais e créditos, o Estado não obriga nem impõe; oferece e necessita de colaboração do particular para que a atividade fomentada seja levada a cabo". (Gaspar Ariño Ortiz. Principios de derecho público económico: modelos de Estado, gestión pública, regulación económica. Granada: Comares, 1990, p. 290).

${ }^{24}$ Segundo pesquisa do IBGE, $32,6 \%$ das entidades sem fins lucrativos são financiadas majoritariamente por recursos públicos. http://www.ibge.gov.br. Acesso em: 19 out. 2008.

${ }^{25}$ Gaspar Ariño Ortiz. Privatización y liberalización de servicios (cit.), p. 19-35. p. 26.

${ }^{26}$ Diogo de Figueiredo Moreira Neto. Coordenação Gerencial na Administração Pública: Administração pública e autonomia gerencial. Contrato de gestão. Organizações sociais. A gestão associada de serviços públicos: consórcios e convênios de cooperação. Revista de Direito Administrativo, Rio de Janeiro, n. 214, out./dez. 1998. p. 39.

${ }^{27}$ A expressão está entre aspas por acreditar-se que as noções de Estado Mínimo e Estado do Bem Estar Social ainda influenciam e convivem com o modelo que se tem adotado, não se configurando, portanto, absolutamente "novo".

${ }^{28}$ Valéria Maria Trezza. O termo de parceria como instrumento de relação público/privada sem fins lucrativos. (cit.), p. 24.

${ }^{29}$ Sílvio Luís Ferreira da Rocha. Terceiro Setor. São Paulo: Malheiros, 2003. (Coleção Temas de Direito administrativo, n. 7.)

${ }^{30}$ Rochelle Pastana Pereira. O Terceiro setor no contexto da democracia e da reforma administrativa do aparelho do Estado. In: Cláudia Fernanda de Oliveira Pereira (Org.). O Novo Direito Administrativo Brasileiro - O Estado, as Agências e o Terceiro Setor. Belo Horizonte: Fórum, 2003, p. 292.

${ }^{31}$ Diogo de Figueiredo Moreira Neto lembra que a imperatividade continuará a existir, mas somente quando for absolutamente necessária e indispensável. (Novos institutos consensuais da ação administrativa. Revista de Direito Administrativo, Rio de Janeiro, n. 231, jan.-mar. 2003. p. 156).

${ }^{32}$ Gustavo Justino de Oliveira. Estatuto Jurídico do Terceiro setor e Desenvolvimento: conectividade essencial ao fortalecimento da cidadania, à luz dos 20 anos da constituição de 1988 (cit.) n. 89, p.431, dez. 2008 a.

Vera Cristina Caspari Monteiro, ao versar sobre a consensualidade, asseverou: "Já se afirmou que a década de 
Sem ruptura com o acima exposto, para Joan Prats I Català, desde meados da década de 90, desponta, especialmente na Europa, "um consenso crescente em torno da eficácia e legitimidade do atuar público, que se fundamenta na qualidade da interação entre os distintos níveis de governo e entre estes e as organizações empresariais e a sociedade civil $^{\prime 33}$. Segundo o autor, os novos modos de governar em que isso se plasma tendem a ser reconhecidos como governança.

A governança não é formada por um único modelo, sendo multifacetada e plural, em busca da eficiência adaptável, que exige flexibilidade, experimentação e aprendizagem por tentativa e erro. Todavia, a despeito de possuir foco diferenciado da administração gerencial, não visa anular, senão reequilibrar os modelos de administração anteriores, incrementando a função de governo como facilitador e cooperador, sem determinar a 'extinção' de suas funções tradicionais $^{34}$. A governança voltar-se-ia mais à efetividade do que à eficiência da administração gerencial, sem, no entanto, deixar de observá-la.

A good governance significaria, ainda, "a condução responsável dos assuntos do Estado", recuperação dos mecanismos de parcerias público-privadas não sob enfoque meramente econômico, insistindo em questões politicamente fortes como governabilidade, responsabilidade e legitimação ${ }^{35}$.

Nesta esteira, para Jacques Chevallier, no cenário do Estado Pós-Moderno, desponta a questão das condições do exercício de poder estatal. Surge o tema da governabilidade, a demandar métodos modernos para tomadas de decisão e de ação ${ }^{36}$, diversos das técnicas governamentais clássicas ${ }^{37}$.

\footnotetext{
90 trouxe novos elementos no campo dos contratos públicos, entre os quais está a tendência segundo a qual as relações contratuais - principalmente as de longo prazo -, sejam elaboradas com base no consenso, em instrumentos jurídicos negociados, que sejam capazes de absorver as crises que sobrevirão durante a sua execução. Isso traz consigo a dificuldade de antecipação dos problemas futuros, com a previsão de mecanismos internos ao contrato para sua solução." (A caracterização do contrato de concessão após a edição da Lei 11.079/2004. 2009. 226 f. Tese [Doutorado em Direito Administrativo] - Faculdade de Direito, Universidade de São Paulo, São Paulo, 2009, p. 67.)

${ }^{33}$ Joan Prats I Català. La construcción social de la gobernanza. In: ; José María Vidal Beltrán (Coords.); et al. Gobernanza: diálogo europeu-iberoamericano sobre el buen gobierno. p. 21-78 Madrid: Editorial Constitución y Leyes; Colex, 2005. p 65.

${ }^{34}$ Ibid., p. 66-67.

35 J. J. Gomes Canotilho. Constitucionalimo e geologia da good governance. In: Brancosos e interconstitucionalidade: itinerários dos discursos sobre a historicidade constitucional. Coimbra: Almedina, 2006. p. 327.

${ }^{36}$ Jacques Chevallier. L'État post-moderne. 2. ed. Paris: LGDJ, 2004, p. 205.

${ }^{37}$ Ibid., p. 203.
} 
Assim, além do Estado, outros atores passam a cooperar na decisão de variados e relevantes temas do governo ${ }^{38}$, "incluindo os cidadãos no processo de determinação do interesse público" 39 com a consequente perda do "monopólio do público" "40. Fortalece-se um sistema de gestão pública baseada em instrumentos consensuais ${ }^{41}$ e negociais contextualizado em um "novo contratualismo administrativo"42 - com utilização de contratos administrativos, acordos, consórcios, termos de parceria, convênios, compromissos de ajustamento de conduta e contratos de gestão.

Não por outra razão, a doutrina aponta o prestígio à cultura do diálogo, a expansão da política de contratualização, utilizando-se das expressões 'governar por contrato', 'administrar por acordos', 'administrar por contrato', 'Administração concertada,43, 'Administração paritária', 'Administração Consensual'44 ou 'Administração Pública

${ }^{38}$ Ibid., p. 205.

${ }^{39}$ Gustavo Justino de Oliveira, ao versar sobre o Estado Mediador, atribui à Administração a tarefa principal de "compor conflitos envolvendo interesses estatais e interesses privados, definitivamente incluindo os cidadãos no processo de determinação do interesse público, que deixa de ser visto como um monopólio estatal, com participação exclusiva de autoridades, órgãos e entidades públicos, e passa a ser compreendido como resultado de processos de harmonização e de ponderação de diversos interesses públicos, interesses privados e interesses das organizações da sociedade civil. Governança pública e parcerias do Estado: a relevância dos acordos administrativos para a nova gestão pública. Revista Ámbito Jurídico, Rio Grande, n. 58, out. 2008b. Disponível

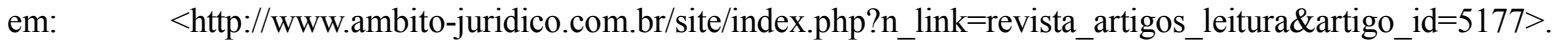
Acesso em: 28 jul. 2009.

Segundo Odete Medauar, o Estado deixa de deter a exclusividade no estabelecimento do interesse público. ( $O$ Direito Administrativo em Evolução [cit.], 2003, p. 211).

${ }^{40}$ Diogo de Figueiredo Moreira Neto. Mutações do Direito Administrativo. 2 ed. Rio de Janeiro: Renovar, 2001. p. 25.

41 “As parcerias firmadas pelo Estado retratam essa nova realidade, e sua compreensão e finalidades não podem ser apreendidas a partir das tradicionais concepções de formalização dos contratos administrativos, pois estamos diante de uma nova forma de administrar, moldada a partir da Governança Pública e da Administração Pública Consensual". Gustavo Justino de Oliveira. Governança pública e parcerias do Estado: a relevância dos acordos administrativos para a nova gestão pública. (cit.), 2008b, p. 433.

42 "Daí a expressão governar por contrato, a qual evocaria a necessidade de o Estado continuamente estabelecer vínculos com a sociedade, como meio para a melhor consecução de suas ações". (Gustavo Justino de Oliveira. Contrato de Gestão. São Paulo: Revista dos Tribunais, 2008c, p. 42.)

O tema também é abordado pelo autor em Governança pública e parcerias do Estado: a relevância dos acordos administrativos para a nova gestão pública. (cit.), $2008 \mathrm{~b}$.

${ }^{43}$ Odete Medauar. O Direito Administrativo em Evolução. (cit.), 2003, p. 209.

${ }^{44}$ Expressões elencadas por Gustavo Justino de Oliveira em Contrato de Gestão (cit.), 2008c, p. 33.

A consensualidade, todavia, não se restringe às parcerias entre o Estado e entes privados, conforme observado por Diogo de Figueiredo Moreira Neto em Mutações do Direito Administrativo (cit., 2001, p. 27): "Expandemse e diversificam-se, em consequência, as formas coordenadas de atuação consensual, tanto pela via da cooperação, que se processa entre entes públicos, como da colaboração, que se dá entre entes públicos e particulares". 
Coordenativa ${ }^{45}$, para traduzir a "necessidade de o Estado estabelecer vínculos mais robustos e permanentes com a sociedade, como meio para a melhor consecução de suas ações"46.

Para tanto, todavia, há de se combater a opacidade e arcana praxis ${ }^{47}$ da Administração Pública, "internalizando" a nova realidade social ${ }^{48}$ e criando zona de intermediação com a sociedade. Estas alterações, no entanto, não implicam em assumir que todas as ações públicas passarão a ser produto de ajuste espontâneo, em total substituição ou ruptura às técnicas tradicionais de governo ${ }^{49}$.

Parte-se, então, de uma visão Estadocêntrica para outra focada nos interesses da sociedade; adotam-se novos procedimentos, compromissos formais e informais do Estado; discute-se o exercício de poder de forma mais aberta, transparente, incluindo novos instrumentos de participação da sociedade sob bases não relacionadas diretamente à proteção do próprio Estado.

Neste cenário, as parcerias entre o primeiro, o segundo e o terceiro setor são cada vez mais presentes e os limites do Estado iniciam processo de redefinição interna, ainda não concluído $^{50}$, passando pela “"despolitização” de uma série de funções estatais”, ${ }^{\text {"51 }}$, criação de órgãos (descentralização), redistribuição de competências e o reconhecimento de entidades privadas para gestão da coisa pública ${ }^{52}$ (privatização e parcerias com a sociedade civil).

No Brasil, também se fizeram sentir muitas das transformações expostas nos parágrafos anteriores, em convício com estruturas e práticas arraigadas de Administração sob outras modalidades de gestão.

A Reforma do Estado no Brasil iniciou-se antes ${ }^{53}$ mesmo da criação do Ministério da Administração e Reforma do Estado (MARE) na década de 90 do século XX, refletindo o

\footnotetext{
45 “[...] a administração pública coordenativa é multilateral, equiordenada e radial, apresentando manifestações consensuais novas e em plena expansão". Diogo de Figueiredo Moreira Neto. Mutações do Direito Administrativo (cit.), 2001, p. 26.

${ }^{46}$ Gustavo Justino de Oliveira. Contrato de Gestão (cit.), 2008c, p. 25.

${ }^{47}$ J.J. Gomes Canotilho. Constitucionalimo e geologia da good governance. (cit.), 2006, p. 332.

48 Esta ausência de internalização pode mesmo impedir a efetivação da governança, a despeito de previsões legislativas favoráveis.

49 Jacques Chevallier. L'État post-moderne (cit.), 2004, p. 207.

${ }^{50}$ Maria João Estorninho. A Fuga para o Direito Privado - Contributo para o estudo da actividade de direito privado da administração pública. Coimbra: Livraria Almedina,1996. p. 96.

${ }^{51}$ Alexandre Santos de Aragão. Administração Pública Pluricêntrica. Revista de Direito Administrativo, Rio de Janeiro, n. 227, p. 131-150, jan./mar. 2002.

${ }^{52}$ Roberto Dromi. Modernización del Control Público (cit.), 2005. p. 10.

${ }^{53}$ Francisco Gaetani lembra-nos que a reforma administrativa de 1967 foi a precursora de muitas ideias no Brasil, "que quase vinte anos depois, viriam a ser apresentadas como parte de uma revolução gerencial". (O recorrente
} 
Direito Público vertentes específicas: "política de privatização ${ }^{54}$ e de desburocratização ${ }^{55}$ da máquina estatal" $" 56$.

Todavia, foi principalmente a partir da década de 90 do século passado que se buscou formatar estruturas burocráticas da Administração em outras mais eficientes, gerenciais, tendo à frente o citado Ministério e Luiz Carlos Bresser Pereira, cuja proposta visou a flexibilização da Administração Pública ${ }^{57}$, participação popular, impressão de maior eficiência na máquina estatal e nos servidores públicos ${ }^{58}$.

Para Diogo de Figueiredo Moreira Neto, a reforma em comento, a despeito de não ter alcançado todos os fins pretendidos ${ }^{59}$, deu-se em duas fases: constitucional, "necessária para a afirmação e reformulação dos novos conceitos e princípios aplicáveis" - a exemplo da

apelo das reformas gerenciais: uma breve comparação. Revista do Serviço Público, Brasília, n. 4, p. 24-25).

${ }^{54}$ Após a Constituição Federal de 1988, a Medida Provisória n. 155/90, convertida na Lei n. 8031/90, por sua vez revogada e substituída pela Lei n. 9491/97, consolidou o Programa Nacional de Desestatização. (Marcos Jordão Teixeira do Amaral Filho. Privatização no Estado Contemporâneo. São Paulo: Ícone, 1996. p. 45).

55 Já com o Programa Nacional de Desburocratização (Decreto n. 83.740/79), deu-se início a processo descentralizador, visando a "dinamizar e simplificar o funcionamento da Administração Federal". Caio Tácito. A reforma do Estado e a modernidade administrativa (cit.), 1999, p. 2.

${ }^{56}$ Caio Tácito. O Retorno do Pêndulo: Serviço Público e Empresa Privada. O Exemplo Brasileiro. Revista Forense, Rio de Janeiro, n. 334, abr./jun. 1996. p. 16.

${ }^{57}$ Francisco Gaetani. O recorrente apelo das reformas gerenciais: uma breve comparação. (cit.), 2003, p. 28.

${ }^{58}$ Paulo Modesto. Reforma Administrativa e marco legal das organizações sociais no Brasil. (cit., ano 3, n. 30, abr. 1999) sintetizou os objetivos práticos que serviram de base finalista aos projetos mais conhecidos de Reforma do Estado:

a) objetivo econômico: diminuir o "déficit" público, ampliar a poupança pública e a capacidade financeira do Estado para concentrar recursos em áreas em que é indispensável a sua intervenção direta;

b) objetivo social: aumentar a eficiência dos serviços sociais oferecidos ou financiados pelo Estado, atendendo melhor o cidadão a um custo menor, zelando pela interiorização na prestação dos serviços e ampliação do seu acesso aos mais carentes;

c) objetivo político: ampliar a participação da cidadania na gestão da coisa pública; estimular a ação social comunitária; desenvolver esforços para a coordenação efetiva das pessoas políticas no implemento de serviços sociais de forma associada;

d) objetivo gerencial: aumentar a eficácia e efetividade do núcleo estratégico do Estado, que edita leis, recolhe tributos e define as políticas públicas; permitir a adequação de procedimentos e controles formais e substituílos, gradualmente, porém de forma sistemática, por mecanismos de controle de resultados.

${ }^{59}$ Quiçá uma das respostas para tal 'frustrada' reforma possa ser explicada por ter sido concebida "como um processo de produção de leis e estruturas organizacionais, sob o pressuposto de que sua existência leva de forma espontânea a melhorar a eficiência e a eficácia. Hoje temos que reconhecer que, apesar das reformas promovidas, os resultados favoráveis têm sido isolados e parciais." (Mario Mora Quirós. Responsabilização pelo controle de resultados. In: Luiz Carlos Bresser Pereira; Nuria Cunill Grau (Coords). Responsabilização na Administração Pública. São Paulo: CLAD/Fundap, 2006. p. 193). 
Emenda Constitucional n. 19/98 60 - e legislativa ordinária, a fim de "complementá-la e darlhe exequibilidade" $" 61$.

Neste contexto, foi editada a Lei n. 9.637/98, que permitiu a entidades tituladas como organizações sociais - OSs o desempenho de atividades de interesse público por meio de contrato de gestão ${ }^{62}$ celebrado com a Administração.

Criou-se, então, um Plano Diretor de Reforma do Aparelho do Estado ${ }^{63}$, duramente criticado sob o mote de que teria por único fim reduzir o seu tamanho ${ }^{64}$ e despir-lhe de suas responsabilidades intrínsecas. Naquele Plano, buscou-se atribuir competências e responsabilidades, com a distinção de quatro setores específicos de ação estatal (núcleo estratégico, setor de atividades exclusivas, setor de serviços não exclusivos e setor de produção de bens e serviços para o $\operatorname{mercado}^{65}$ ), conforme a natureza de suas atividades, associando-os a três modalidades de propriedade (pública, pública não-estatal e privada) e formas de gestão ${ }^{66}$. O terceiro setor encontrar-se-ia no setor de serviços não-exclusivos ${ }^{67}$ do

${ }^{60}$ Acerca do conteúdo da Emenda Constitucional, verificar artigo de Carlos Alberto Menezes Direito: "Reforma Administrativa: A Emenda n. 19/98" (Revista de Direito Administrativo, Rio de Janeiro, n. 213, p. 133-139, jul./set. 1998).

${ }^{61}$ Diogo de Figueiredo Moreira Neto. Mutações do Direito Administrativo, (cit.), 2001. p. 17.

De acordo com Paulo Modesto: "A reforma administrativa do aparelho do Estado no Brasil tem na introdução e alteração de normas no âmbito da Constituição da República e das leis uma de suas etapas necessárias". Reforma Administrativa e marco legal das organizações sociais no Brasil. (cit.), ano 3, n. 30, abr. 1999.

${ }^{62}$ Analisaremos oportunamente o contrato de gestão e as organizações sociais.

${ }^{63}$ BRASIL. Presidência da República. Câmara da Reforma do Estado. Plano Diretor da Reforma do Aparelho do Estado. Brasília, DF, nov. 1995. Disponível em: http://www.planalto.gov.br/publi_04/COLECAO/PLANDI.HTM. Acesso em: set. 2008.

${ }^{64}$ Rochelle Pastana Ribeiro. O Terceiro setor no contexto da democracia e da reforma administrativa do aparelho do Estado, (cit.), 2003. p. 295.

${ }^{65}$ Em linhas gerais, o núcleo estratégico seria aquele correspondente ao Estado, em sentido lato, que define as leis e as políticas públicas. As atividades exclusivas, ao setor no qual os serviços prestados somente o podem ser pelo Estado, como regulamentar, fiscalizar e fomentar. Já os serviços não exclusivos, corresponderiam ao que simultaneamente poderia atuar com outras organizações públicas não-estatais, como universidades, hospitais, centro de pesquisas e os museus. Por fim, a produção de bens e serviços para o mercado, que corresponderia à área de atuação de empresas, como atividades econômicas voltadas para o lucro. BRASIL. Presidência da República. Câmara da Reforma do Estado. Plano Diretor da Reforma do Estado. (cit.), 1995. Disponível em: http://www.planalto.gov.br/publi 4/COLECAO/PLANDI2.htm. Acesso em: 23 set. 08.

${ }^{66}$ Fernando Borges Mânica. Panorama histórico-legislativo do Terceiro setor no Brasil: do conceito de Terceiro setor à Lei das OSCIPs. In: Gustavo Justino de Oliveira (Coord.). Terceiro setor, Empresas e Estado: novas fronteiras entre o público e o privado. Belo Horizonte: Fórum, 2007b. p. 182.

${ }^{67}$ Para Joaquim Falcão, pela Reforma do Estado tenta-se "restringir as atividades diretas àquelas que seriam 'atividades exclusivas do Estado'. Atividades não-exclusivas, que podem ser delegadas sem prejuízo para o interesse público, desde que reguladas e fiscalizadas, ficariam para o setor privado" Democracia, Direito e Terceiro setor. Rio de Janeiro: Fundação Getulio Vargas, 2004. (p 141. 
Estado $^{68}$, para o qual "a proposta da reforma levada a cabo defendia que a modalidade mais adequada à eficiência na prestação de tais serviços seria a propriedade pública não-estatal"69.

Também no Brasil, lembra Gustavo Justino de Oliveira, "surge uma nova e importante noção para a gestão pública brasileira: a Governança Pública",70, visando a "efetividade da ação governamental",71, à qual se coadunam previsões legais voltadas ao consenso, à negociação, à participação efetiva da sociedade na definição do conteúdo de instrumentos e políticas públicas $^{72}$.

Assim, diante da complexidade da sociedade, da heterogeneidade de interesses, da afirmação pluralista ${ }^{73}$ e das demandas sociais $^{74}$, combinadas com a ineficiência, a incapacidade de atender satisfatoriamente a sociedade em todos os aspectos e a escassez de recursos públicos ${ }^{75}$, o Estado passou a desempenhar função fomentadora de modo mais intenso. Destaca-se a celebração de parcerias com as entidades privadas sem fins lucrativos (não limitadas às OSs do "Plano Diretor"), incentivando-as mediante transferências de recursos públicos, titulações, qualificações, certificações e incentivos fiscais, dentre outros.

Ademais, maximiza-se a ideia de "subsidiariedade" - ainda que despida de definição unívoca. Alguns autores consideram-na semelhante a uma repartição de competência entre sociedade e Estado $^{76}$, com a valorização das atribuições daquela, não no sentido estrito e

${ }^{68}$ De certa forma, as ideias propostas no "Plano de Reforma" acerca dos serviços não-exclusivos 'contaminaram' a visão de diversos autores, que passaram a atribuir ao terceiro setor e às parcerias a noção de que seriam exclusivamente instrumentos do Estado para diminuir sua estrutura e responsabilidades.

${ }^{69}$ Fernando Borges Mânica. Panorama histórico-legislativo do Terceiro setor no Brasil: do conceito de Terceiro setor à lei das OSCIPs (cit.), 2007, p. 183.

${ }^{70}$ Gustavo Justino de Oliveira. Governança pública e parcerias do Estado: a relevância dos acordos administrativos para a nova gestão pública (cit.), 2008b, p. 429.

${ }^{71}$ Gustavo Justino de Oliveira. Contrato de Gestão (cit.), 2008c, p. 26.

${ }^{72}$ Cita-se a Lei Municipal n.14.667/08, da Prefeitura de São Paulo, que criou a Secretaria Municipal de Participação e Parceria, cabendo-lhe em especial "garantir a participação da sociedade civil e de segmentos sociais específicos da população na construção e implementação de políticas públicas destinadas ao desenvolvimento e à melhoria das condições de vida no Município".

${ }^{73}$ Odete Medauar. O Direito Administrativo em Evolução. (cit.), 2003, p. 210.

${ }^{74}$ Neste sentido, Karina Brunet (Crise do Estado: participação e solidariedade. Revista de Informação Legislativa, Brasília, n. 152, out.-dez. 2001. p. 207) e Lucas Rocha Furtado (Curso de Direito Administrativo. Belo Horizonte: Fórum, 2007. p. 226).

${ }^{75}$ Carlos Eduardo Vieira de Carvalho. Os novos caminhos do direito administrativo no contexto evolutivo do Estado de direito. In: Cláudia Fernanda de Oliveira Pereira. (Org.) O Novo Direito Administrativo Brasileiro: O Estado, as Agências e o Terceiro Setor. Belo Horizonte: Fórum, 2003. p. 336.

${ }^{76}$ José Alfredo de Oliveira Baracho. O Princípio de Subsidiariedade: Conceito e Evolução. Rio de Janeiro: Forense, 2000. p. 48. 
exclusivo de maior eficiência e economicidade ${ }^{77}$, mas como "critério nas relações entre esfera de atuação estatal e a iniciativa privada, para conferir primazia a esta e caráter residual àquela"78.

Para José Alfredo de Oliveira Baracho, a subsidiariedade, apesar "de sugerir uma função de suplência ${ }^{79}$, [...] compreende, também, a limitação da intervenção de órgão ou coletividade superior" $" 80$, sendo que "as competências completam-se em função das necessidades e das suplências, possibilitando que o princípio de subsidiariedade realize-se através do instrumento de participação ou mesmo de parceria" ${ }^{\sharp 1}$.

A subsidiariedade não serve à intenção de excluir do Estado suas atribuições, cujo exercício é indispensável para a maior parte da população ${ }^{82}$. Isto porque, apesar de 'perder' alguns de seus poderes em favor da sociedade, o Estado, ressalta Joan Prats I Català, continua relevante ${ }^{83}$.

Neste cenário e como um dos efeitos correlatos das transformações pelas quais o Estado passou - e ainda passa, houve no Brasil notável "redescoberta ${ }^{84}$ da sociedade civil, rebatizando-a, como se viu, de setor público não-estatal" ${ }^{85}$ ou esfera pública não-estatal ${ }^{86}$.

${ }^{77}$ Segundo Roberto Dromi, “o princípio da subsidiariedade é um princípio jurídico, fundado na justiça, não é um princípio 'técnico' fundado na eficácia ou melhor rendimento, senão uma garantia e tutela dos direitos essenciais da pessoa humana" - tradução livre. Derecho Administrativo (cit.), 1996. p. 25.

${ }^{78}$ Odete Medauar. O Direito Administrativo em Evolução (cit.), 2003, p. 245.

79 De acordo com Roberto Dromi: “O Estado intervém para suprir, dos mais diversos modos, a todas as comunidades intermédias, inseridas entre ele e o indivíduo. Esses modos de ação podem ser: 'fomentar', 'estimular', 'coordenar', 'suprir', 'completar' e 'integrar' a iniciativa particular e grupal, nos âmbitos social, econômico, laboral, profissional etc.” Derecho Administrativo (cit.), 1996. p. 25-26.

${ }^{80}$ José Alfredo de Oliveira Baracho. O Princípio de Subsidiariedade: Conceito e Evolução. (cit.), p. 26.

${ }^{81}$ Ibid., p. 50.

${ }^{82}$ Critica Tarso Cabral Violin no sentido de que: “[...] a aplicação do princípio da subsidiariedade nos países subdesenvolvidos nos remete à necessidade de um Estado interventor e prestador de serviços, uma vez que o 'terceiro setor' e o mercado não são suficientes para garantir a emancipação do indivíduo, o fim das desigualdades, uma sociedade justa. Assim, exemplificativamente, se na Europa Ocidental a aplicação do princípio da subsidiariedade nos leva à diminuição direta do Estado e repasse dos serviços sociais ao "terceiro setor', não há como esta regra ser seguida, ipisis litteris, em nosso tão desigual país”. (Terceiro setor e as Parcerias com a Administração Pública - Uma Análise Crítica. Belo Horizonte: Fórum, 2006. 287).

${ }^{83}$ Joan Prats I Català. La construcción social de La gobernanza. (cit.), 2005, p. 29.

84 Em pesquisa realizada pelo IBGE e o Instituto de Pesquisa Econômica Aplicada (Ipea), em parceria com a Associação Brasileira de Organizações Não-Governamentais (Abong) e o Grupo de Institutos, Fundações e Empresas (Gife), tendo por ano-base 2005, estimou-se que as fundações e associações sem fins lucrativos (Fasfil) em atividade no Brasil são em torno de 338.000 (trezentas e trinta e oito mil). Segundo consta, todavia, apesar de, entre 2002 a 2005, o número de Fundações Privadas e Associações sem Fins Lucrativos ter crescido 22,6\%, esse crescimento foi de 157,0\% entre 1996 e 2002 o que sinaliza uma desaceleração no crescimento dessas instituições em todo o país. (IBGE, 2008. Disponível em: http://www.ibge.gov.br. Acesso em: 07 out. 08).

De todo modo, é inegável o crescimento constante do setor. Tal fato, além dos dados governamentais disponíveis, também tem sido percebido pela doutrina, como, por exemplo, por Rodrigo Pironti Aguirre de Castro (O sistema de controle interno e as entidades do Terceiro setor: perspectiva gerencial e o princípio da eficiência. In: Gustavo Justino de Oliveira (Coord.). Direito do Terceiro Setor. Belo Horizonte: Fórum, 2008. p. 167) e José Roberto 
A gestão privada de recursos públicos para fins públicos decorrentes de política fomentadora estatal e da aplicação do princípio da subsidiariedade suscitou debates intensos no que tange à determinação dos princípios, das regras e dos procedimentos a que devam sujeitar-se as entidades do terceiro setor que os recebam com a obrigação de realizar atividades de "benefício comum" 87 , com reflexos imediatos na determinação do seu controle e respectivos órgãos controladores.

A própria noção do que seja "público" ou "privado" passa a ser discutida ${ }^{88}$, "como um dos reflexos do convívio entre o Estado e as entidades do terceiro setor", segundo Odete Medauar, "para se cogitar não mais uma separação rígida, mas a flexibilização das relações, o intercâmbio, a busca de critérios de coexistência" ${ }^{89}$. Neste sentido, para Arnoldo Wald, viu-se

Pimenta Oliveira, que critica tal fenômeno e a destinação de recursos públicos a título de fomento estatal como um dos motivos deste crescimento: "Muito mais que fomentar, assiste-se, acriticamente, ao sustentar, por parte da Administração, de entidades privadas sem fins lucrativos, no desempenho de atividades que passam a contar com significativos recursos e bens, incluindo servidores estatais, na sua atividade ou custeio.

Tudo isso sem o correlativo incremento de estruturas fiscalizatórias das relações jurídico-administrativas travadas." (José Roberto Pimenta Oliveira. Improbidade administrativa e Terceiro setor. In: Renata Porto Adri; Luis Manuel Fonseca Pires; Maurício Zockun (Coords.); et al. Corrupção, ética e moralidade administrativa. Belo Horizonte: Fórum, 2008. p.168).

${ }^{85}$ Expressão utilizada por Maria Tereza Fonseca Dias. Terceiro setor e Estado: Legitimidade e Regulação - por um novo marco jurídico. Belo Horizonte: Fórum, 2008a. p. 96.

${ }^{86}$ Segundo Gustavo Justino de Oliveira: "Nesse cenário, parece ser possível identificar, de um lado, a existência de uma esfera pública ou esfera pública estatal; de outro, a existência de uma esfera pública não-estatal, espaço no qual desponta, no Brasil, o denominado Terceiro setor. [...]. É possível afirmar que o recente interesse pelo Terceiro setor é uma das decorrências das políticas reformistas de Estado, ocorridas nas últimas décadas do século XX, as quais provocaram, em muitos casos, o desmantelamento das estruturas públicas voltadas à prestação de serviços sociais à comunidade.”. Estatuto Jurídico do Terceiro setor e Desenvolvimento: Conectividade Essencial ao Fortalecimento da Cidadania, à Luz dos 20 anos da Constituição de 1988. (cit.), 2008a, p. 1087.

${ }^{87}$ Expressão de Gustavo Justino de Oliveira. OSCIPS e Licitação: ilegalidade do Decreto n. 5.504, de 05.08.05. (Parecer). Revista Eletrônica sobre a Reforma do Estado - RERE, Salvador, Instituto Brasileiro de Direito Público, n. 12, dez.-fev, 2008d. Disponível em: http://www.direitodoestado.com.br/redae/asp. Acesso em: 10 out. 2008.

88 "E pergunta-se então: qual o direito aplicável, público, privado, a mescla de ambos, ou se utiliza de modo indiferente o privado ou o público?". Odete Medauar. O Direito Administrativo em Evolução (cit.), 2003, p. 212.

A questão não foi ainda equacionada, podendo pender para a estatização das entidades do terceiro setor ou para ausência de sua disciplina: "A disciplina das entidades que compõem o terceiro setor é extremamente complexa, especialmente em suas relações com o Estado, já que, ao passo em que colaboradoras na consecução dos direitos fundamentais, tais entidades devem ser fiscalizadas e controladas a fim de que se garanta a efetiva concretização de tais direitos sem que com isso se imponha um regime idêntico àquele aplicado sobre o próprio Estado. [...]. Se, de um lado, com a projeção da disciplina que regulamenta a atividade estatal às entidades do terceiro setor corre-se o risco de estatizar e, em última análise, aniquilar tais entidades da sociedade civil, de outro, deixar de disciplinar a atuação do terceiro setor, em especial nos casos em que haja alguma modalidade de apoio estatal ao desempenho de suas atividades, implica a possibilidade de esvaziamento da Administração Pública, do Direito Administrativo e do próprio Estado." Fernando Borges Mânica. Participação privada na prestação de serviços públicos de saúde. Tese (Doutorado). Faculdade de Direito, Universidade de São Paulo, 2009. p. 188.

89 Entendimento esposado pela doutrinadora na introdução à obra de Gustavo Justino de Oliveira. (cit.), 2007b, p. 12. 
diminuída a distinção entre o público e o privado, visualizando situações tangentes entre os dois direitos, sendo semi-públicas e semi-privadas ${ }^{90}$.

Também o Direito Administrativo sofreu modificação em suas antigas concepções e atributos tradicionais ${ }^{91}$, com introdução de novos paradigmas $^{92}$, renovando-se $^{93}$, enriquecendo-se ${ }^{94}$, evoluindo ${ }^{95}$, reformulando-se ${ }^{96}$, atualizando-se e revitalizando-se ${ }^{97}$ para entrar em sintonia com o novo cenário de "complexização da sociedade" 98 , tendendo a revelar uma feição mais democrática ${ }^{99}$, participativa ${ }^{100}$, flexível $^{101}$. Passou a receber denominações como "direito administrativo pactualista, direito administrativo cooperativo"102, "direito administrativo participativo"103 num contexto no qual se questiona se há de fato "crise do direito administrativo' ou mera 'metamorfose, 104 , se o "direito administrativo atual está

${ }^{90}$ Arnoldo Wald. As novas tendências do Direito Administrativo. Revista do Ministério Público, Rio de Janeiro, n. 17, 2003.p. 97.

${ }^{91}$ Jacques Chevallier. L'État de droit. Paris: Montchrestien, 2003. p. 143-144.

92 Como o "fortalecimento da negociação na esfera da Administração Pública, expressada por via de acordos", segundo Gustavo Justino de Oliveira. Contrato de Gestão (cit.), 2008c, p. 24.

${ }^{93} \mathrm{Na}$ opinião de Luís Roberto Barroso, no prefácio de obra de Gustavo Binenbojm (Uma Teoria do Direito Administrativo - Direitos Fundamentais, Democracia e Constitucionalização. 2 ed. São Paulo: Renovar, 2008).

${ }^{94}$ Para Diogo de Figueiredo Moreira Neto, por exemplo, a consensualidade seria um enriquecimento do Direito Administrativo. (Mutações do Direito Administrativo. Rio de Janeiro: Renovar, 2001. p. 41).

${ }^{95}$ Alexandre Santos de Aragão. Administração Pública Pluricêntrica, (cit.), 2002. p. 132.

${ }^{96}$ Arnoldo Wald. As novas tendências do Direito Administrativo, (cit.), 2003, p. 93.

${ }^{97}$ Odete Medauar. O Direito Administrativo em Evolução (cit.), 2003, p. 267.

${ }^{98}$ Alexandre Santos de Aragão. Administração Pública Pluricêntrica, (cit.), 2002, p. 132.

${ }^{99}$ Carlos Eduardo Vieira de Carvalho. Os Novos Caminhos do Direito Administrativo no Contexto Evolutivo do Estado de Direito (cit.), 2003, p. 337.

${ }^{100}$ Ibid., p. 342.

${ }^{101}$ Segundo Arnoldo Wald, há duas tendências paralelas e complementares: "De um lado, flexibiliza-se o direito administrativo, nele incluindo-se fórmulas de direito privado com as adaptações necessárias. De outro, delegase aos particulares a realização de determinados serviços públicos, de acordo com a regulamentação e sob a fiscalização do Estado, multiplicando-se as parcerias”. As novas tendências do Direito Administrativo, (cit.), 2003, p. 93.

102 Odete Medauar. O Direito Administrativo em Evolução (cit.), 2003, p. 212.

${ }^{103}$ Caio Tácito. Transformações do Direito Administrativo. Revista de Direito Administrativo, Rio de Janeiro, $\mathrm{n}$. 214, p. 27-34, out./dez. 1998. p. 30.

${ }^{104}$ Odete Medauar. O Direito Administrativo em Evolução (cit.), 2003, p. 268. 
fadado a morrer"105, se há retração ou encolhimento"106, "construção, desconstrução e reconstrução do Direito Administrativo brasileiro" ${ }^{107}$.

A demonstrar as transformações pelas quais passa o Direito Administrativo e a importância das parcerias celebradas com entidades sem fins lucrativos, cogita-se de um Direito do terceiro setor ${ }^{108}$, autônomo àquele ${ }^{109}$.

Em apertada síntese, certas tendências podem ser extraídas deste contexto: a evidência de "abertura de consideráveis espaços para a consensualidade"110, a assimilação da novel realidade do relacionamento Estado-sociedade ${ }^{111}$ e a ampliação $^{112}$ dos limites do ramo do Direito Público para alcançar entidades privadas fora do espaço puramente estatal, ao disciplinar atividades de cunho social por elas prestadas ${ }^{113}$ e para versar sobre outros temas que não os clássicos ${ }^{114}$.

Ainda, percebe-se a tendência de maior fiscalização (social e estatal) ${ }^{115}$ das referidas entidades, sobretudo ao receberem recursos públicos a título de fomento ${ }^{116}$, por meio das

${ }^{105}$ Carlos Ari Sundfeld. A administração pública na era do direito global. Revista Diálogo Jurídico, Salvador, CAJ - Centro de Atualização Jurídica, ano I, vol. 1, n. 2, maio, 2001. Disponível em: http://www.direitopúblico.com.br. Acesso em: 06 mar. 2008.

${ }^{106}$ Odete Medauar. O Direito Administrativo em Evolução (cit.), 2003, p. 270.

${ }^{107}$ Egon Bockmann Moreira. Terceiro setor da administração pública. Organizações sociais. Contrato de gestão. - Organizações sociais, organizações da sociedade civil de interesse público e seus "vínculos contratuais" com o Estado. Revista de Direito Administrativo, Rio de Janeiro, n. 227, p. 309-320, jan.-mar. 2002. p. 309.

108 Conforme percebido por Joaquim Falcão, o marco legal das entidades em comento constitui-se de um conjunto heterogêneo e complexo de normas juridicamente diferenciadas. (Democracia, Direito e Terceiro setor. Rio de Janeiro: Fundação Getúlio Vargas, 2004. p 148). Basta verificar o poder normativo da IN n. 01/97, do Decreto Federal n. 5.504/05, dentre outros incidentes sobre as entidades privadas sem fins lucrativos.

109 “[...] o ramo do Direito que estuda o Terceiro setor, disciplinando, em especial, a organização e o funcionamento das entidades privadas sem fins lucrativos, as atividades de interesse público por elas levadas a efeito e as relações por elas desenvolvidas entre si, com órgãos e entidades integrantes do aparato estatal (Estado), com entidades privadas que exercem atividades econômicas eminentemente lucrativas (mercado) e com pessoas físicas que para elas prestam serviços remunerados ou não remunerados (voluntariado), segundo Gustavo Justino de Oliveira. Direito do Terceiro Setor. Revista de Direito do Terceiro Setor - RDTS, Belo Horizonte, ano 1, n. 1, p. 35, jan./jun. 2007a.

${ }^{110}$ Gustavo Justino de Oliveira. Contrato de Gestão (cit.), 2008c, p. 32.

${ }^{111}$ Como destacam Odete Medauar (O Direito Administrativo em Evolução. 2.ed. rev. atual. e ampl. São Paulo: Revista dos Tribunais, 2003. p. 266) e Gustavo Justino de Oliveira (Direito do Terceiro Setor. Belo Horizonte: Fórum, 2008e. p. 35.

112 Roberto Dromi, ao versar sobre “entes públicos não-estatais”, assim se manifesta: "A aplicação dos conceitos expostos amplia o campo do direito público, incorporando muitas instituições que de outro modo, por não serem estatais, restariam reservadas à exclusiva regulação do direito privado". - tradução livre. Derecho Administrativo (cit.), 1996. p. 131.

${ }^{113}$ Conforme entendimento de Marçal Justen Filho. Curso de Direito Administrativo, 3. ed. rev. atual. São Paulo: Saraiva, 2008. p. 04.

${ }^{114}$ Odete Medauar. O Direito Administrativo em Evolução, (cit.), 2003, p. 268.

115 Observou Maria Tereza Fonseca Dias que metade das decisões e acórdãos proferidos pelo TCU em matéria de 
parcerias inseridas no "fenômeno da nova contratualização administrativa"117 e expansão do consensualismo, que "confere novos usos à categoria jurídica contrato no setor público"118 e ao próprio controle ${ }^{119}$.

Para Pedro Gonçalves, porque as entidades do terceiro setor dedicam-se ao bem comum desenvolvendo atividades de interesse público (não tipicamente privadas), a dimensão do Estado regulador tem o dever de garantir (responsabilidade pública de garantia) ou de responder "pelos resultados da cooperação entre Estado e privados", de satisfazer o interesse público e as necessidades da coletividade. Não por outra razão, tem regulado o setor, reconhecendo oficialmente as entidades por meio de titulações, qualificações, certificações e atribuindo regime particular de controle e fomento, regulação essa "dirigida aos actores privados (regulação de direito privado) [que] deverá aparecer, em muitos casos, inspirada por valores de direito público" $" 120$.

Aprofundando-se a questão da fiscalização neste contexto, verifica-se a tendência ${ }^{121}$

parceria entre a Administração Pública e o terceiro setor foi posterior a 2007. Acrescentamos que é de se notar a defasagem entre a edição das leis das OSs e OSCIPs e o volume de decisões no TCU a respeito. Apesar de o título de utilidade pública existir desde 1935 e de os convênios com o terceiro setor para transferência de recursos públicos também serem anteriores às referidas leis, ao que parece, a celebração de parcerias (em especial os convênios) se intensificou, bem como o volume de recursos transferidos após as suas edições, com o correlato aumento da atuação de controle pelo TCU. (O Exercício do Papel Regulador do Tribunal de Contas da União sobre as parcerias da Administração pública com as entidades do Terceiro setor na execução de Políticas públicas. In: CONGRESSO NACIONAL DO CONPEDI, 17., Brasília, DF, 2008. Anais eletrônicos. Brasília, DF, 2008b. p. 3456-3486. Disponível em: http://www.conpedi.org/manaus/arquivos/anais/brasilia/10_598.pdf. Acesso em: 28 jul. 2009.

${ }^{116}$ Consigna Célia Cunha Mello: "De fato, o particular é livre para aderir ou não aos propósitos do Estado, mas, a partir do momento em que manifesta sua vontade de assumir a posição de agente fomentado, obriga-se a atender a todas as condições impostas pelo Estado, ficando inteiramente vinculado aos fins públicos pretendidos, pois são eles os responsáveis pelos privilégios e vantagens que lhe foram outorgados." ( $O$ Fomento da Administração Pública. Belo Horizonte: Del Rey, 2003, p. 30).

A título de exemplo de fomento: "Este ano, a Secretaria da Saúde enviará R\$ 1,75 bilhão para 49 hospitais, centros de saúde e Ambulatórios Médicos de Especialidades (AMEs) gerenciados por Organizações Sociais de Saúde (OSS), entidades sem fins lucrativos do terceiro setor. A assinatura dos contratos de gestão aconteceu no dia 23 dezembro de 2008." (PORTAL DO GOVERNO DO ESTADO DE SÃO PAULO. Organizações Sociais de Saúde receberão R\$ 1,75 bilhão em 2009. 02/01/09. Disponível em: $<$ http://www.saopaulo.sp.gov.br/spnoticias/lenoticia.php?id=101861\&c=6>. Acesso em: mar. 2009.).

${ }^{117}$ Gustavo Justino de Oliveira. Contrato de Gestão (cit.), 2008c. p. 45.

${ }^{118}$ Ibid., p. 46

119 “[...] o papel reservado ao contrato de gestão é o de substituir o sistema de controle baseado no princípio da legalidade e na supremacia do interesse público sobre o privado pelo controle baseado no princípio da consensualidade, na cooperação, no qual as metas são negociadas e preestabelecidas pelas partes". Sílvio Luís Ferreira da Rocha. Terceiro Setor. (cit.), 2003. p. 38.

120 "Na medida em que, no processo de activação de responsabilidades privadas, estão envolvidos interesses e objetivos incluídos no dever estadual de garantia, o Estado não pode deixar de assumir o dever de assegurar o cumprimento das responsabilidades privadas". Pedro Gonçalves. Entidades Privadas com Poderes Públicos: o exercício de poderes públicos de autoridade por entidades privadas com funções administrativas. Coimbra: Almedina, 2005. p. 163-169.

121 Segundo Márcia Pelegrini. A competência sancionatória do Tribunal de Contas no exercício da função 
de controle da eficiência ${ }^{122}$ do manejo dos recursos públicos transferidos e do alcance das metas estabelecidas para a prestação dos serviços de interesse social pelas entidades em exame, controle este que se pretende "de garantia""123, "de gestão"124, "de alcance de resultado" "125, de satisfação do usuário e não "eminentemente formalista"126, legalista,

controladora: contornos constitucionais. Tese (Doutorado em Direito do Estado) - Departamento de PósGraduação em Direito, Pontifícia Universidade Católica de São Paulo, São Paulo, 2008. Disponível em: http://www.sapientia.pucsp.br//tde busca/arquivo.php?codArquivo=7957. Acesso em: mar. 2009.

122 Para Rodrigo Pironti Aguirre de Castro: “[...] o princípio da eficiência preocupa-se com os meios empregados e com o atingimento de seus resultados, uma vez que não constitui um fim em si mesmo e deve estar corroborado por todos os demais princípios do texto constitucional." (O sistema de controle interno e as entidades do Terceiro setor: perspectiva gerencial e o princípio da eficiência. In: Gustavo Justino de Oliveira (Coord.). Direito do Terceiro Setor. Belo Horizonte: Fórum, 2008e. p. 168).

Emerson Gabardo, ao versar sobre o princípio da eficiência administrativa, tece a seguinte crítica: "Bem se sabe que no Plano Diretor da Reforma do Aparelho do Estado, que deu origem à tal inclusão, a ideia predominante era a desconstitucionalização, rumo a um neoliberalismo debilitado na forma de Administração Gerencial. [...]. Dessa forma, tão importante quanto a relação com os demais princípios da Administração Pública, que não é só externa, mas intrínseca, é a submissão do princípio da eficiência aos princípios estruturantes (ou fundamentais) do sistema constitucional, entre os quais se destaca o Princípio do Estado Social e Democrático de Direito." (Princípio constitucional da eficiência administrativa. São Paulo: Dialética, 2002. p. 89-90).

${ }^{123}$ Conforme Pedro Gonçalves: “[...] impõe-se que o Estado assuma um grau de responsabilidade compatível com o seu dever constitucional. [...] É neste contexto que se fala de 'responsabilidade pública de garantia' [...] o Estado não se demite do dever geral de assegurar ou garantir que os actores privados produzem aqueles bens e, em geral, cumprem as incumbências que lhes são cometidas para se alcançarem os resultados pretendidos [...]”. Entidades Privadas com Poderes Públicos: o exercício de poderes públicos de autoridade por entidades privadas com funções administrativas (cit.), 2005. p. 166-168.

124 Segundo Massimo Severo Giannini, mostram-se cada vez mais eficazes os controles como o de gestão. (Diritto Amministrativo. 3. ed. Milão: Giuffre, 1993. Vol. I. p. 331-332). Em termos práticos, esclarece-se que o controle de gestão visa aferir o alcance de metas ou de resultados mediante a aplicação de recursos, sendo mais relacionado aos termos de parceria e contrato de gestão, enquanto que o controle da aplicação de recursos é o que analisa se estes foram aplicados nos fins previstos, independentemente do exame de se ter atingido os fins almejados.

A respeito do controle de gestão, Odete Medauar assevera: "Evidente que um controle tão abrangente como o de gestão, que recai sobre um conjunto de atividades desenvolvidas para o atingimento de um objetivo, absorve o de legalidade e o de mérito e tem a vantagem, segundo se depreende do acompanhamento simultâneo da atuação, com medidas corretivas a cada passo, impedindo a dispersão e o mau uso dos recursos alocados; por outro lado, quebra a rigidez da estrutura hierarquizada, sem deixar, no entanto, de observar certo escalonamento, pela existência de um agente controlador e de um chefe de projeto". Controle da Administração Pública. São Paulo: Revista dos Tribunais, 1993. p. 47.

A doutrina aponta para novas tendências de fiscalização: “As demandas por melhores serviços e busca de economicidade e efetividade no uso dos recursos públicos, têm pautado as ações dos cidadãos, que progressivamente vêm exigindo transparência, honestidade, moralidade e excelência na Administração Pública. Por essas razões, no exercício do seu papel constitucional, o TCU tem se voltado para a realização de fiscalizações focadas no desempenho da entidade auditada, bem como na eficiência, na eficácia e na efetividade das ações governamentais. Essas tendências têm se revelado por meio dos instrumentos de fiscalização" assim elencados: auditoria de desempenho, auditorias ambientais, acompanhamento da desestatização e fiscalização de obras, na esteira de Jair Lima Santos. Tribunal de Contas da União \& controles estatal e social da administração pública. Curitiba: Juruá, 2003. p. 82-86.

125 “A responsabilização pelos resultados na administração pública sustenta-se na avaliação ex post das políticas e programas como meio para medir seu desempenho e exigir a prestação de contas dos diretores e funcionários públicos responsáveis, tanto por sua execução como pelos resultados obtidos. Pressupõe a confrontação entre as metas estabelecidas (compromissos adquiridos) e os resultados finalmente obtidos (realizações), de maneira tal que o grau de consistência entre 'metas' e 'resultados' gere a informação requerida para aproximar o nível 
procedimental, a posteriori ou de mera aplicação de recursos. Não se nega, com isso, o uso simultâneo de mecanismos de fiscalização que se complementam ${ }^{127}$, como controle de gestão e controle hierárquico ${ }^{128}$, prévio e concomitante.

Não existe, no entanto, um modelo ideal para a gerência pública de uma sociedade democrática $^{129}$, mas o controle de gestão aplicar-se-ia com muito mais propriedade a um cenário no qual desponta a gestão privada de recursos públicos, em razão de parceria celebrada com o Estado para fins públicos. Com o exame pari passo da gestão do recurso público transferido, seria examinada, assim, a escorreita atuação do privado parceiro na sua aplicação e alcance dos resultados almejados.

Ademais, a responsabilização por resultados "constitui um sinal de maturidade política" e pressupõe a consolidação "de um modelo de gestão pública flexível e criativo, que outorgue aos responsáveis pelos programas maior liberdade para tomar decisões e administrar

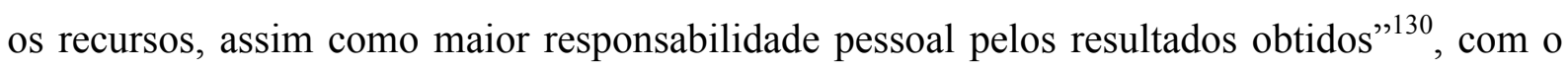
estabelecimento de um sistema de programação ${ }^{131}$, execução e avaliação ${ }^{132}$.

de desempenho do governo e dos governantes". Mario Mora Quirós. Responsabilização pelo controle de resultados. In: Luiz C. Bresser Pereira; Nuria C. Grau (Coords); et al. Responsabilização na Administração pública: coletânea. São Paulo: CLAD/Fundap, 2006. p. 166.

${ }^{126}$ Rodrigo Pironti Aguirre de Castro é incisivo: "importa uma análise do controle das ações das entidades do Terceiro setor pelo Sistema de Controle Interno da Administração, mormente em relação a sua eficiência e análise de resultados." O sistema de controle interno e as entidades do Terceiro setor: perspectiva gerencial e o princípio da eficiência. (cit), 2008. p. 167.

${ }^{127}$ Mario Mora Quirós. Responsabilização pelo controle de resultados (cit.), 2006, p. 178.

${ }^{128} \mathrm{O}$ controle de gestão “(...) recai sobre um conjunto de atividades desenvolvidas para atendimento de um objetivo, absorve o de legalidade e de mérito e tem a vantagem [...] do acompanhamento simultâneo da atuação, com medidas corretivas a cada passo, impedindo a dispersão e o mau uso dos recursos alocados; por outro lado, quebra a rigidez da estrutura hierarquizada, sem deixar, no entanto, de observar certo escalonamento, pela existência de um agente controlador e de um chefe de projeto". Odete Medauar. Controle da Administração Pública (cit.), 1993. p. 49.

${ }^{129}$ Mario Mora Quirós. Responsabilização pelo controle de resultados, (cit.), 2006, p. 178.

${ }^{130}$ Mario Mora Quirós. Responsabilização pelo controle de resultados, (cit.), 2006, p. 170-171.

131 “O êxito da responsabilização pelos resultados inicia-se durante a etapa de programação orçamentária. Nela são estabelecidas as prioridades, desenham-se as políticas e os programas, são fixadas as metas e atribuídos os recursos correspondentes para o seu funcionamento. Para impulsionar uma prestação de contas efetiva, o vínculo entre políticas, recursos e metas deve refletir-se de maneira clara e transparente no orçamento. [...] Considera-se usualmente que a avaliação ex post é de pouca utilidade, argumentando-se que tem um alcance muito limitado e que detecta erros quando já é tarde demais para enfrentá-los. No entanto, esse aparente fracasso é explicado por duas razões fundamentais: primeiro, a inadequada programação das políticas e dos programas; segundo, a ausência de acompanhamento durante sua fase de execução”. (Ibid., p. 171)

132 “A responsabilização pelos resultados resgata a avaliação como um instrumento de gerência pública e não só como uma ferramenta de controle ex post. Em uma perspectiva ampla e dinâmica, a avaliação adquire uma dupla dimensão: por um lado apóia a tomada de decisões para cumprir as metas estabelecidas e melhorar o desempenho e, por outro lado, avalia os resultados obtidos a fim de medir o desempenho e promover a prestação de contas dos diretores e funcionários públicos". E em "geral, a avaliação tem sido entendida como um mecanismo de controle externo e não como uma ferramenta gerencial para a tomada de decisões”. (Ibid., p. 175 e 196). 
Para a doutrina, "os controles tradicionais perderam efetividade à medida que o setor público tornou-se mais complexo e foram sendo redefinidas as relações Estado-sociedade". Entretanto, "os novos controles de gestão por resultados acabam por não se implantar e mostrar-se limitados, o que dispara as possibilidades de corrupção e não de uma boa gestão" 133 , pois "a experiência tem demonstrado que os controles estatais estão longe de serem suficientes para garantir uma reta administração pública"134. A "manifestação crescente de atos de corrupção [por sua vez] fez com que as reformas neste campo se movessem na outra direção, ou seja, focalizando a atenção na quantidade e não na qualidade dos controles", limitando o avanço em curto prazo para esquemas de controle modernos ${ }^{135}$.

Também como motivos apontados para tais assertivas acerca dos controles, para Diogo de Figueiredo Moreira Neto, eles também tendem a se burocratizar; mostraram ser pouco eficientes e tornaram-se cada vez mais dispendiosos ${ }^{136}$.

Segundo Joan Prats I Català, a imperfeição do controle de gestão provém da ignorância da dependência dos interesses gerais da colaboração e coordenação entre uma pluralidade de atores públicos, privados e civis ${ }^{137}$. Ainda que desejável um governo mais eficiente, só a eficiência, aduz, não garante um governo melhor ${ }^{138}$. Neste sentido, Mario Mora Quirós alerta que "a transformação do Estado como um processo integral que procure níveis crescentes de eficiência faz sentido somente se as ações executadas conduzirem a um maior bem-estar social, refletindo melhorias sustentadas na qualidade de vida dos indivíduos e das comunidades" ${ }^{\text {139 }}$.

Ademais, Mario Mora Quirós, ao versar sobre o controle de resultado, consigna que:

Sua implementação pressupõe vontade política para incentivar reformas múltiplas e simultâneas voltadas para modernizar o processo orçamentário, os sistemas de controle interno e externo, assim como a administração geral dos recursos públicos (humanos, físicos e financeiros). Pressupõe também o desafio de redefinir o papel e as responsabilidades de todas as entidades que intervêm na atribuição, na execução, no controle e na avaliação dos recursos públicos, assim como fortalecer os mecanismos que permitem a participação social na fiscalização e no controle da ação governamental ${ }^{140}$.

\footnotetext{
${ }^{133}$ Joan Prats I Català. La construcción social de la gobernanza, (cit.), 2005, p. 28.

${ }^{134}$ Diogo de Figueiredo Moreira Neto. Mutações do Direito Administrativo (cit.), 2001. p. 25.

${ }^{135}$ Mario Mora Quirós. Responsabilização pelo controle de resultados (cit.), 2006. p. 174

${ }^{136}$ Diogo de Figueiredo Moreira Neto. Mutações do Direito Administrativo (cit.), 2001, p. 25.

${ }^{137}$ Joan Prats I Català. La construcción social de la gobernanza, (cit.), 2005, p. 63.

${ }^{138}$ Ibid, p. 64.

${ }^{139}$ Mario Mora Quirós. Responsabilização pelo controle de resultados (cit.), 2006. p. 165.

${ }^{140}$ Ibid, p. 166.
} 
Outrossim, a "multiplicidade e duplicidade de controles, excessivos e irrelevantes, contribuíram para a conformação de aparatos públicos rígidos, fragmentados, dispersos e menos efetivos, construídos sobre estruturas verticais pouco funcionais"141. Apesar de o autor reconhecer o esforço empreendido no Brasil com a reforma gerencial, aduz: "em geral, prevaleceu um enfoque centrado no controle externo" e, "embora desde 1988 o âmbito de ação de Tribunais de Contas tenha se ampliado para incluir o controle e a fiscalização contábil, financeira e orçamentária, operacional e patrimonial, na prática ele ainda concentra a maior parte de seus esforços no controle da legalidade"142, fazendo-se necessário "simplificar e modernizar os sistemas de controle externo, como parte integral de uma nova gestão pública baseada no princípio de maior delegação, maior flexibilidade no uso dos recursos públicos e maior responsabilização pelos resultados obtidos"143.

Concernente às entidades do terceiro setor gestoras de recursos públicos para fins públicos, há tendência no sentido de sua sujeição a idênticos mecanismos de controle aplicados à atuação estatal. Sobretudo quando os críticos da reforma administrativa gerencial apontam como um dos motivos de seu crescimento a fuga às vinculações jurídico-públicas a que a Administração de outro modo estaria sujeita ${ }^{144}$, os argumentos para aplicação do direito público a essas entidades têm sido acatados sem muitas ressalvas.

Constata-se propensão legal, doutrinária e jurisprudencial, de entendimento no sentido de haver tentativa de "fuga" 145 para o regime privado a ser parcialmente "impedida" pela

\footnotetext{
${ }^{141}$ Ibid., p. 174.

142 Ibid., p. 203.

${ }^{143}$ Ibid., p. 212.

${ }^{144}$ De acordo com Maria Tereza Fonseca Dias. Terceiro setor e Estado: Legitimidade e Regulação - por um novo marco jurídico (cit.), 2008a. p. 93.

145 A “questão da fuga" ao regime privado é tratada por muitos autores, dentre os quais, Lucas Rocha Furtado: "A rigor, a criação pública, por meio de lei, de entidades instrumentais estranhas à Administração do Estado está ligada a uma única verdade: busca-se fugir aos controles a que se sujeita a Administração Pública. Sob o argumento de que a gestão privada dos recursos públicos importa em solução mais efetiva, abrem-se as portas para todo tipo de malversação e abuso com os recursos públicos.” Curso de Direito Administrativo (cit.), 2007. p. 234.
}

Tarso Cabral Violin, por sua vez, consigna: “[...]. Ora, se há dinheiro para ser transferido às entidades do 'terceiro setor', via parcerias, este poderia ser aplicado na prestação direta dos serviços sociais pelo Estado. Os argumentos do gerencialismo-neoliberal apenas tentam esconder um dos motivos para a desresponsabilização do Estado na questão social, que é a fuga do regime jurídico administrativo, principalmente da realização de concurso público e licitação, procedimentos tão importantes para o atendimento aos princípios da moralidade, isonomia, entre outros, mas tão criticados pelos gerencialistas que defendem os controles de resultados e não de meios, além da preponderância do princípio da eficiência." Terceiro setor e as Parcerias com a Administração Pública - Uma Análise Crítica (cit.), 2006. p. 283.

Também José Roberto Pimenta Oliveira adota este posicionamento: “Observa-se, pois, em realidade, é uma tendência de uma monumental fuga da organização administrativa através do desproporcional crescimento da atuação de entidades privadas sem fins lucrativos integradas à função administrativa do Estado. Como fenômeno 
aproximação ao regime ${ }^{146}$ e pelos instrumentos de controle incidentes sobre as entidades da Administração Pública às privadas sem fins lucrativos em comento. Alternativamente, alguns defendem a manutenção do regime jurídico público $^{147}$ à gestão de recursos públicos do particular, como proposta de solução adotada para sanar as dificuldades envolvidas no novo fenômeno que se vivencia.

Em outras palavras, se de um lado, as pretendidas transformações do Estado e do Direito Administrativo buscam abarcar novos paradigmas, dentre eles a consensualidade ${ }^{148}$ na formação de vínculos, a regulação do fomento por meio de instrumentos legais e a flexibilização das regras de gestão, por outro, sofrem limitações quando do advento do controle, realizado pelos tradicionais órgãos de fiscalização e pela própria Administração Pública, com fundamento em legislação infraconstitucional ou infralegal que, aos poucos, equiparam as entidades privadas sem fins lucrativos, gestoras de recursos públicos, aos órgãos estatais ${ }^{149}$.

social, este fenômeno busca seu amparo ideológico na Reforma (redutora) do Estado exigida pelo ideário neoliberal, em cujo bojo se pretende implantar um Estado Regulador (não mais Estado Prestador), disseminando, em seu seio, um amplo arsenal de técnicas de privatização, sob alegação de maior eficiência e necessidade de redução da burocracia governamental”. Improbidade Administrativa e Terceiro setor (cit.), 2008, p.166.

Também Maria Sylvia Zanella Di Pietro. Parcerias na Administração Pública - concessão, permissão, franquia, terceirização, parceria público-privada e outras formas. 6 ed. São Paulo: Atlas, 2008. p. 264.

Roberto Dromi, no entanto, aduz que: "Nos antecipamos às respostas, concluindo que se está figurando uma nova relação entre o Estado e o indivíduo, mas ela de nenhum modo significa uma fuga do direito administrativo; pelo contrário, há sim uma transformação do direito administrativo, pois ele é peça chave entre Estado e indivíduo." - tradução livre. Derecho Administrativo (cit.), 1996. p. 58.

${ }^{146}$ Para Maria João Estorninho: "Na minha opinião, [...] o '1. round' do 'combate' à fuga para o Direito Privado ganha-se no momento em que a doutrina, numa era de grandes incertezas e a propósito de um tema cujas fronteiras não estão sequer bem definidas, toma consciência de forma relativamente unânime do próprio fenómeno e passa a afirmar a necessidade de evitar tal 'fuga'. [...]. Julgo poder concluir-se ser hoje indiscutível a necessidade de impor tais vinculações jurídico-públicas, como única maneira eficaz de evitar a 'fuga' para o Direito Privado [...].”.A Fuga para o Direito Privado - Contributo para o estudo da actividade de direito privado da administração pública (cit.),1996. p. 160-161.

${ }^{147}$ Foi esta a constatação de Natasha Schmitt Caccia Salinas: "Nas parcerias entre o poder público e o terceiro setor aqui examinadas, embora os gestores de recursos públicos sejam instituições privadas, a gestão propriamente dita do dinheiro repassado permanece pública. As regras de emprego, gestão e controle de recursos acabam por condicionar ou mesmo restringir o regime privado ao qual as entidades sem fins lucrativos estão originalmente submetidas". Avaliação Legislativa no Brasil: um estudo de caso sobre as normas de controle das transferências voluntárias de recursos públicos para entidades do terceiro setor. 2008. 256 f. Dissertação (Mestrado em Direito) - Faculdade de Direito, Universidade de São Paulo, São Paulo, 2008. p. 107.

${ }^{148}$ Lembre-se que a preferência pela consensualidade decorre das seguintes razões elencadas por Diogo de Figueiredo Moreira Neto: colaboração, cooperação, economicidade, agilidade, publicização, modernização, generalidade e subsidiariedade. Mutações do Direito Administrativo. (cit.), 2001, p. 28.

${ }^{149}$ Neste sentido, são exemplos as alterações introduzidas até mesmo por recomendação do Tribunal de Contas da União na Instrução Normativa n. 01/97; a edição do Decreto n. 5.504/05 (que instituiu a obrigação de adoção de pregão preferencialmente eletrônico pelas entidades que celebrarem convênios, contratos de gestão e termos de parceria com o Poder Público); do Decreto n. 6.170/07 (que estabeleceu novas regras para a celebração de convênios e contratos de repasse); do Decreto n. 6.428/08 (pelo qual as entidades privadas interessadas em celebrar convênio e contrato de gestão deverão realizar cadastro prévio no Sistema de Gestão de Convênios e Contratos de Repasse-SICONV); do Decreto n. 6.497/08 (que alterou em parte o Decreto n. 6.428/08); do 
Nesta esteira, "se os efeitos da bilateralidade encontram-se fortes na formação dos contratos administrativos, eles vão sendo relativamente diluídos ou enfraquecidos no transcurso da relação instaurada pelo ajuste", "na execução dos contratos administrativos". Até mesmo na "formação dos contratos administrativos, visualiza-se um abrandamento dos efeitos oriundos dessa bilateralidade, pois uma das características de tais ajustes encontra-se no fato de representarem autênticos contratos de adesão" ${ }^{150}$, fenômeno presente nos instrumentos de parceria com o terceiro setor, que pouco ou nada pode interferir na sua redação.

Ainda, verifica-se a imposição pelos Tribunais de Contas de regras tradicionais de fiscalização a serem exercidas pela administração pública sobre o terceiro setor - cerceandolhe em parte a competência para determinação e flexibilização da gestão dos bens públicos, quando justamente uma das medidas que desencadearia processo contínuo de reformas seria a implantação de controle de resultados e de gestão, segundo Odete Medauar ${ }^{151}$. No entanto, a questão torna-se, sobretudo complexa ao se constatar a "ineficácia dos controles institucionais implementados para o acompanhamento estatal das entidades"152.

Desta forma, para alguns, "a pretendida flexibilização das regras de gestão de recursos em prol do controle de resultados ${ }^{153}$ das ações desenvolvidas pelos entes parceiros não se tornou realidade" 154 , bem como, na contramão da proposta inserida na Reforma Administrativa do Estado, tem-se estabelecido instrumentos normativos de controles burocráticos ${ }^{155}$, com a aplicação praticamente integral do direito público às entidades privadas gestoras de recursos públicos.

Pedro Gonçalves identificou o fenômeno como ausência de clara distinção entre os tratamentos regulatórios, em especial jurídicos, que merecem os casos nos quais há efetiva transferência aos entes privados das tarefas tradicionalmente atribuídas ao Estado, daquela de complementaridade dos papéis desempenhados pelo Estado e pelos privados:

Decreto n. 6.170/07 e da Portaria Interministerial n. 127/2008 (que alterou algumas regras destes últimos decretos e regulamentou a relação dos controles interno e externo), em flagrante inversão de hierarquia legislativa.

${ }^{150}$ Todas as citações extraídas da obra de Gustavo Justino de Oliveira. Contrato de Gestão (cit., 2008c. p. 31).

${ }^{151}$ Odete Medauar. Direito Administrativo Moderno. 11.ed. São Paulo: Revista dos Tribunais, 2007a, p. 28.

${ }^{152}$ Maria Tereza Fonseca Dias. Terceiro setor e Estado: Legitimidade e Regulação - por um novo marco jurídico. (cit.), 2008a. p. 94.

153 Odete Medauar. Direito Administrativo Moderno (cit.), 2007a, p. 28.

${ }^{154}$ Natasha Schmitt Caccia Salinas. Avaliação legislativa no Brasil: um estudo de caso sobre as normas de controle das transferências voluntárias de recursos públicos para entidades do terceiro setor (cit.), 2008. p. 109.

${ }^{155}$ Márcia Pelegrini. Terceiro setor: gestão privada de recursos públicos. Revista de Direito do Terceiro Setor, Belo Horizonte, ano 1, n. 2, p. 63, jul./dez. 2008. 
[...] as novas formas de auto-regulação privada regulada não reclamam a ruptura com a tradicional dicotomia entre público e privado, não estão na génese de uma nova 'tricotomia', nem identificam uma zona de concurso ou de 'competência conjunta do Estado e da Sociedade'. Ao contrário, a auto-regulação privada publicamente regulada pretende representar uma zona do espaço social caracterizada pela complementaridade e pela cooperação entre público e privado, cooperação, todavia, em que cada sector actua na sua esfera de responsabilidades, com funções próprias e diferenciadas: os actores públicos no exercício de funções públicas legislativas e administrativas (regulação pública), os actores privados na execução de actividades privadas e no exercício dos seus direitos e deveres (auto-regulação privada).

[...] Embora possa reconhecer-se que o facto de os particulares terem sido envolvidos na execução de tarefas tradicionalmente consideradas típica e irredutivelmente públicas pode diluir as fronteiras, outrora nítidas, entre público e privado, deve contudo sublinhar-se que, no âmbito da auto-regulação privada regulada, é pública apenas a regulação que disciplina e que se aplica à actuação dos particulares; a actividade que estes exercem pertence à esfera privada. Remeter, neste caso, a acção dos particulares para a esfera pública (e do direito público) traduz ainda o resultado de uma desactualizada visão dualista ${ }^{156}$, segundo o qual onde há prossecução de interesses públicos, há necessariamente actuação pública, regulada pelo direito público ${ }^{157}$

Parece-nos que, não obstante a regra geral seja a de as entidades em comento submeterem-se ao regime privado, ao se tornarem parceiras do Estado e receberem recursos públicos, passam a incidir-lhes alguns princípios e regras de direito público ${ }^{158}$, resultante “de bases normativas postas pelo ordenamento jurídico pátrio", como é o caso da obrigação constitucional de prestação de contas (art. 70, parágrafo único da $\mathrm{CF})^{159}$. Não se trata de um terceiro regime jurídico, mas da aplicação de preceitos de direito privado e de direito público, conforme previsão expressa na legislação.

Contextualizado o tema do presente trabalho, entende-se pertinente delimitar o que seja o terceiro setor para os seus fins.

\footnotetext{
156 “[...] a dicotomia entre Estado e Sociedade estava associada a uma clara repartição das titularidades sobre as tarefas públicas e as tarefas privadas e uma distinção clara entre as respectivas naturezas: as primeiras, confundidas com tarefas de interesse público, pertenciam ao Estado; as segundas, ligadas à satisfação de interesses privados, competiam à Sociedade e aos cidadãos. Ora, também essa dicotomia liberal entrou em crise, sendo indiscutível que o Estado perdeu o monopólio do "público"'. Pedro Gonçalves. Entidades Privadas com Poderes Públicos: O Exercício de Poderes Públicos de Autoridade por Entidades Privadas com Funções Administrativas (cit.), 2005. p. 142.

${ }^{157}$ Pedro Gonçalves. Entidades Privadas com Poderes Públicos: O Exercício de Poderes Públicos de Autoridade por Entidades Privadas com Funções Administrativas (cit.), 2005. p. 174-175.

${ }^{158}$ Para Márcia Pelegrini: “[...] quando as entidades do terceiro setor os prestam [serviços de interesse públicos], o fazem sob o regime de direito privado, mas de forma diferenciada dos particulares que prestam tais serviços, eis que, sendo elas entidades sem fins lucrativos, recebem repasses de dinheiro público para atuarem ao lado do Estado, desempenhando de forma complementar atividades de responsabilidade deste. Assim, é de se considerar que o regime de direito público deve necessariamente incidir, uma vez que estão envolvidos recursos públicos, estando tais entidades necessariamente sujeitas ao controle do Tribunal de Contas." Terceiro setor: gestão privada de recursos públicos. Revista de Direito do Terceiro Setor, Belo Horizonte, ano 1, n. 2 , jul./dez. 2008. p. 61.

${ }^{159}$ Segundo Gustavo Justino de Oliveira. Estatuto Jurídico do Terceiro setor e Desenvolvimento: Conectividade Essencial ao Fortalecimento da Cidadania, à Luz dos 20 anos da Constituição de 1988 (cit.), 2008a.
} 


\subsection{Terceiro setor}

\subsubsection{Noção de terceiro setor}

A despeito de alguns autores entenderem equivocada a utilização da expressão "terceiro setor" no Brasil, não se pode negar sua corriqueira aplicação ${ }^{160}$ e coadunar-se ao sistema constitucional pátrio, possuindo como vantagem adicional a aceitação no meio acadêmico e social ${ }^{161}$.

Fernando Borges Mânica, sem adotar conceito amplo e residual do Terceiro setor ${ }^{162}$, esclarece a respeito:

[t]raduzido do inglês third sector, essa nova expressão, difundida a partir da década de 60 do século passado, tem sido utilizada genericamente para se referir às organizações formadas pela sociedade civil, cujo objetivo não é a busca pelo lucro, mas a satisfação do interesse público. Situa-se ao lado do primeiro setor, ocupado pelo Estado, e do segundo setor, do qual fazem parte as entidades privadas com finalidade lucrativa ${ }^{163}$.

Para Vital Moreira, o terceiro setor compartilha de traços do primeiro e do segundo setores, sendo intermediário entre o Estado e o mercado, entre o setor público e o privado ${ }^{164}$.

O "terceiro setor" não possui definição jurídica ${ }^{165}$, tampouco conceito unívoco ${ }^{166}$, podendo-se a ele referir-se genericamente como constituído por entidades sem fins

${ }^{160}$ Alexandre Ciconello. O conceito legal de público no Terceiro setor. In: Eduardo Szazi (org.). Terceiro setor Temas Polêmicos 1. São Paulo: Peirópolis, 2004. p. 51.

161 Luis Eduardo Patrone Regules. Notas sobre os princípios constitucionais da Administração pública e as Organizações do Terceiro setor. In: Darlan Barroso; et al. Direito Constitucional: temas atuais. São Paulo: Método, 2007. p. 109.

${ }^{162}$ A consagração da noção de que tudo o que não for primeiro nem segundo constituirá o terceiro setor não recebe tranquila acolhida na doutrina: "[...] para a dogmática jurídica, a adoção de um conceito de Terceiro setor correspondente à totalidade das entidades sem fins lucrativos é inútil, pois a tal categoria não corresponde um regime jurídico próprio, já que o universo das entidades constituídas sem fins lucrativos envolve uma multiplicidade de ações, objetivos e interesses, cada qual sujeito a determinado conjunto de normas jurídicas". Fernando B. Mânica. Panorama histórico-legislativo do Terceiro setor no Brasil: do conceito de Terceiro setor à Lei das OSCIP (cit.), 2007b, p. 167.

${ }^{163}$ Fernando Borges Mânica. Terceiro setor e Imunidade Tributária - Teoria e Prática. Belo Horizonte: Fórum, 2005.p. 57

${ }^{164}$ Vital Moreira. Auto-regulação profissional e Administração Pública. Coimbra: Almedina, 1997. p. 33.

165 José Eduardo Sabo Paes. Fundações, associações e entidades de interesse social: aspectos jurídicos, administrativos, contábeis, trabalhistas e tributários. 6. ed. Brasília: Brasília Jurídica, 2006. p. 123.

${ }^{166}$ Gustavo Justino de Oliveira. Contrato de Gestão (cit.), 2008c. p. 278. 
lucrativos $" 167$, voltadas ao interesse público e não ao interesse corporativo ${ }^{168}$.

A doutrina nacional, ainda, ora delimita o terceiro setor como conjunto de entidades que desenvolvem atividades de pressão sobre órgãos e poderes estatais, voltadas a finalidades públicas ou sociais, ora leva em conta o aspecto específico da prestação de certos serviços ${ }^{169}$.

Leandro Marins de Souza ${ }^{170}$, por entender que "[a]s denominações encontradas nos textos legais são as mais diversas, apesar de muitas vezes estarem se referindo à mesma situação jurídica", adotou definição ampla, considerando a área de atuação das entidades:

O terceiro setor é, a nosso sentir, de acordo com o percurso evolutivo dos movimentos constitucionais brasileiros e, sobretudo, com a Constituição Federal de 1988, toda ação, sem intuito lucrativo, praticada por pessoa física ou jurídica de natureza privada, como expressão da participação popular, que tenha por finalidade a promoção de um direito social ou seus princípios ${ }^{171}$.

Abraçando definição mais restrita de terceiro setor, em razão do universo das entidades consideradas nele integrantes e sem limitação à esfera de sua atuação, Gustavo Justino de Oliveira, por sua vez, estabelece-o como sendo:

o conjunto de atividades voluntárias, desenvolvidas por organizações privadas nãogovernamentais e sem ânimo de lucro (associações ou fundações), realizadas em prol da sociedade, independentemente dos demais setores (Estado e mercado), embora com eles possa firmar parcerias e deles possa receber investimentos (públicos e privados ${ }^{172}$.

Segundo esta definição, para dada pessoa jurídica de direito privado integrar o terceiro setor, não se faz necessário decorrer de lei (é voluntária), deter qualquer titulação ou qualificação pelo Estado, ou com ele celebrar parceria. Tampouco limita as atividades que dada entidade possa desenvolver, se realizadas em prol da sociedade (e não de associados, por exemplo) e sem ânimo de lucro, o que não impede de tê-lo (lucro). Em outras palavras, o conceito transcrito não delimitou o terceiro setor a partir de uma visão Estadocêntrica, voltada para a qualificação, certificação, titulação ou transferência de recursos públicos por meio de parcerias.

\footnotetext{
${ }^{167}$ Fernando Borges Mânica. Panorama histórico-legislativo do Terceiro setor no Brasil: do conceito de Terceiro setor à Lei das OSCIP (cit.), 2005. p. 59.

${ }^{168}$ Fernando Borges Mânica. Terceiro setor e Imunidade Tributária - Teoria e Prática (cit.), 2007b. p. 170.

${ }^{169}$ Ibid., p. 171-173.

${ }^{170}$ Leandro Marins de Souza. Tributação do Terceiro setor no Brasil. São Paulo: Dialética, 2004. p. 95.

${ }^{171}$ Ibid., p. 96.

${ }^{172}$ Gustavo Justino de Oliveira. Estado contratual, direito ao desenvolvimento e parceria público-privada. p. 86. In: Eduardo Talamini (Coord.); et al. Parceria público-privada: uma abordagem multidisciplinar. São Paulo: RT, 2005a, p. 83-119.
} 
A Lei federal das organizações da sociedade civil de interesse público - OSCIPs, considerada por muitos como "a lei do terceiro setor" de modo ainda mais estrito, para fins de concessão daquela titulação: "a pessoa jurídica de direito privado que não distribui, entre os seus sócios ou associados, conselheiros, diretores, empregados ou doadores, eventuais excedentes operacionais, brutos ou líquidos, dividendos, bonificações, participações ou parcelas do seu patrimônio, auferidos mediante o exercício de suas atividades, e que os aplica integralmente na consecução do respectivo objeto social" (art. 1, §1). Para alguns, "a Lei da OSCIP oferece critérios legais para a definição do terceiro setor", ainda que este não se limite às entidades qualificadas como $\operatorname{OSCIP}^{174}$, sobretudo por excluir instituições voltadas para a defesa de interesses restritos a dada categoria de pessoas (por exemplo, sindicatos) e ser-lhe intrínseca a ideia de colaboração com o Estado.

O Anteprojeto de Lei que institui o estatuto do terceiro setor considerou este como sendo formado por pessoas jurídicas de direito privado, de caráter voluntário e sem fins lucrativos que (i) desenvolvam atividades de promoção e defesa de direitos, principalmente os coletivos e difusos; (ii) realizem atividades de interesse público, assistência social ou utilidade pública, nos termos definidos em lei; ou (iii) prestem serviços sociais diretamente à população, em caráter complementar ou suplementar aos serviços prestados pelo Estado (art. 2) ${ }^{175}$.

Ao Tribunal de Contas do Estado de São Paulo - TCESP, por sua vez, o terceiro setor seria "representado por cidadãos integrados em organizações sem fins lucrativos, nãogovernamentais, voltados para a solução de problemas sociais e com o objetivo de gerar serviços de caráter público" $" 176$.

Segundo o Instituto Brasileiro de Geografia e Estatística - IBGE, as "entidades sem fins lucrativos" restringem-se às organizações sociais, organizações da sociedade civil de interesse

\footnotetext{
173 “A Lei das OSCIPs surgiu com o objetivo de transpor uma barreira: a inadequação da legislação disciplinadora das entidades do Terceiro setor, em especial no que se refere às suas relações com o Poder Público”. Fernando Borges Mânica. Panorama histórico-legislativo do Terceiro setor no Brasil: do conceito de Terceiro setor à Lei das OSCIP. [cit.], 2007c. p. 186.

174 Ibid., p. 188.

${ }^{175}$ No art. 4, indicou as entidades que não podem ser enquadradas como terceiro setor aquelas:

(i) Autorizadas ou criadas por lei;

(ii) Aquelas em cujos órgãos de direção, deliberação e administração haja representantes do Poder Público;

(iii) Aquelas mantidas por contribuições fiscais e parafiscais do Poder Público, como as entidades do Sistema $\mathrm{S}$;

(iv) As entidades destinadas a proporcionar bens ou serviços a um segmento restrito de associados ou sócios, em regime de mutualidade; e

(v) Aquelas com natureza de sindicatos, associações de classe ou de representação de categoria profissional.

${ }^{176}$ BRASIL. TCE-SP. MANUAL BÁSICO - Repasses Públicos ao Terceiro Setor. 2007.p 12.
} 
público, outras fundações mantidas com recursos privados, filiais no Brasil de fundações ou associações estrangeiras e outras formas de associação, excluindo expressamente os sindicatos e serviços sociais autônomos, dentre outros ${ }^{177}$. Tal delimitação foi configurada a partir do exame do Cadastro Central de Empresas - CEMPRE e do estabelecimento dos seguintes critérios: entidades privadas não integrantes do Estado, sem fins lucrativos, legalmente constituídas, capazes de gerenciar suas próprias atividades e voluntárias.

Verifica-se nos dados do IBGE a importância de ser a entidade legalmente constituída e autônoma ao Estado (voluntária), independentemente dos fins visados (de interesse público ou mútuo) ou de seu objeto (prestação de serviços, fomento, defesa de direitos etc.).

A Constituição Federal, por sua vez, sem mencionar a expressão "terceiro setor", utiliza-se de sete denominações de entidades privadas colaboradoras: instituições privadas (particulares) de educação (ensino) - arts. 150, VI, c; 206, III; 209 e 213; instituições de assistência social (entidades beneficentes, de assistência social, filantrópicas) - arts. 150, VI, c; $195, \S 7^{\circ} ; 199, \S 1^{\text {o }} ; 204$, I; terceiros e pessoas de direito privado na área de saúde - arts. 197 e 199, § 1ºn ; entidades filantrópicas e aquelas sem fins lucrativos - art. 199, § $1^{\text {o }}$; organizações representativas da população ou de segmentos dessa - arts. $5^{\circ}$, XVIII, LXX, b; $58, \S 2^{\circ}$, II; $74, \S 2^{\circ}$ e 204, II; escolas comunitárias - art. 213, e entidades de previdência - art. 21, VIII; o que não impede a previsão de outras em legislação infraconstitucional.

A respeito das definições de terceiro setor transcritas, cabem, ainda, derradeiras considerações.

Acerca da formatação jurídica, as entidades do terceiro setor seriam aquelas estruturadas sob a forma de associação - constituídas para fins não-econômicos ${ }^{178}$ - ou fundação ${ }^{179}$, conforme o Código Civil ${ }^{180}$. Não nos parece possível defender o terceiro setor composto por entidades não institucionalizadas, independentemente de possuírem ou não relação com o Estado.

\footnotetext{
${ }^{177}$ Segundo consta, o número em 2005 era de 338.162 organizações, situadas principalmente na região sudeste e criadas após 1990 (41,5\%), sendo novas, em sua maioria, voltadas para a promoção do desenvolvimento e defesa de direitos e interesses dos cidadãos (associações de moradores, centros e associações comunitárias, defesa de direitos de grupos e minorias, desenvolvimento rural, emprego e treinamento, associações patronais e empresariais, associações profissionais etc.), inclusive o grupo das associações patronais e profissionais. BRASIL. As fundações privadas e associações sem fins lucrativos no Brasil 2005/IBGE, Rio de Janeiro: IBGE, 2008. p. 7-61.

${ }^{178}$ Lucas Rocha Furtado. Curso de Direito Administrativo, (cit.), 2007. p. 227.

179 José Eduardo Sabo Paes. Fundações, associações e entidades de interesse social: aspectos jurídicos, administrativos, contábeis, trabalhistas e tributários (cit.), 2006. p. 131.

${ }^{180}$ Art. 45 e seguintes para associação e artigos 62 a 69 para fundação. Não pretendemos aprofundar as eventuais restrições impostas pelo Código Civil por serem impertinentes ao tema.
} 
Reflexo do amadurecimento da noção de terceiro setor na Administração Pública gerencial e governança é a tendência da doutrina adotar como critério definidor das pessoas jurídicas sem fins lucrativos dele integrantes, o fim público ou fim comunitário ${ }^{181}$ - e não o benefício mútuo ${ }^{182}$ ou favorecimento mútuo ${ }^{183}$, previsto na Lei Federal n. 9.790/99, que exclui as de benefício mútuo do rol de organizações passíveis de qualificação como OSCIP ${ }^{184}$. Isto porque o interesse mútuo, a princípio, não coadunaria com o ideal da colaboração entre Estado e sociedade, sendo sua atuação específica, não geral, pública.

Na mesma esteira, o Tribunal de Contas da União - TCU exclui do terceiro setor "as entidades civis sem fins lucrativos de beneficio mútuo, ou seja, aquelas que se dirigem apenas para seus associados, de natureza endógena, de interesses coletivos, mas não públicos" ${ }^{\text {"185 }}$, entendimento este adotado por outras Cortes. ${ }^{186}$

Outra questão diz respeito à expressão "organização não-governamental" - ONG, também utilizada para designar as entidades integrantes do terceiro setor, não representando no direito brasileiro, uma forma de organização jurídica específica de entidades privadas. Por isso, não é disciplinada em nenhum texto legislativo ou ato normativo, a despeito de lhe fazerem referência ${ }^{187}$.

Para o TCESP, do ponto de vista jurídico, o termo ONG não é aplicável, pois a legislação apenas reconhece dois formatos institucionais: as associações e fundações privadas.

\footnotetext{
${ }^{181}$ Paulo Modesto. Reforma do marco legal do Terceiro setor no Brasil (cit.), ano 3, n. 30, abr. 1999, p. 8.

${ }^{182}$ Expressão utilizada por José Eduardo Sabo Paes. Fundações, associações e entidades de interesse social: aspectos jurídicos, administrativos, contábeis, trabalhistas e tributários (cit.), 2006. p. 123-124.
}

Ressalte-se que, para autores como Lucas Rocha Furtado, a exclusão das cooperativas do terceiro setor teria como fundamento justamente o fato de visarem interesses privados de seus cooperados ou sócios e por terem escopo empresarial, sob o argumento de que, a despeito de o acesso ao trabalho ser um interesse coletivo e do Estado, este não se confunde com o interesse individual dos cooperados por trabalho e com o fato de serem remunerados, como é visado pelas cooperativas. Lucas Rocha Furtado. Curso de Direito Administrativo, (cit.), 2007. p. 227.

${ }^{183}$ Paulo Modesto. Reforma do marco legal do Terceiro setor no Brasil (cit.), ano 3, n. 30, abr. 1999, p. 8.

${ }^{184}$ A distinção serviria, dentre outros motivos, para legitimar o repasse de recursos públicos: se os fins visados forem de interesse geral, tanto mais legítimo o recebimento de recursos para atendê-los.

${ }^{185}$ Cf. BRASIL. TCU, Acórdão n 1331, de 09 de julho de 2008. Plenário. Disponível em: http://www.tcu.gov.br. Acesso em: 03 out. 2008

${ }^{186}$ No Estado de Pernambuco, há vedação à celebração de contrato de gestão e termo de parceria - que serão objeto de explanação neste trabalho - com organizações de ajuda mútua, "que objetivam a defesa de interesses de um círculo restrito de pessoas, associados ou sócios, a exemplo de associações de classe e sindicatos". BRASIL. TCE-PE, Resolução n. 0020/2005, 2005. Disponível em: http://www.tce.pe.gov.br/resolucaovirtual/2005/r202005.htm. Acesso em: 29 set. 2008.

${ }^{187}$ É o caso da Lei Orgânica de Assistência Social (Lei n. 8.742/1993) em seu art. 26, conforme lembrado por Gustavo Justino de Oliveira, autor das citações supra. Direito do Terceiro Setor. Revista de Direito do Terceiro Setor, Belo Horizonte, ano 1, n. 1, jan./jun. 2007a. p. 18-19. 
Delimita o termo, todavia, como sendo organização privada não lucrativa, independente, prestadora de serviços sociais em geral de modo voluntário ${ }^{188}$.

Por ser "ONG" e organização não governamental" expressões, assim como "terceiro setor", aceitas e aplicadas pela doutrina e Tribunais de Contas, serão utilizadas neste trabalho indistintamente, a fim de designar o mesmo conteúdo.

Quanto à expressão "entidades paraestatais", também utilizada para se referir ou integrar as entidades do terceiro setor, não se encontra na doutrina nacional definição unânime. Para Odete Medauar, alguns autores dela se utilizam para abranger o que define como "entes com situação peculiar", entendidos como "dotados de características que não se enquadram exatamente nos moldes previstos legalmente para identificar as entidades componentes da Administração indireta, nem permitem situá-los como órgãos da Administração direta" (as ordens e conselhos profissionais, as fundações de apoio, as empresas controladas pelo Poder Público, os serviços sociais autônomos, as OSs e as OSCIPs). Na esteira da autora, todavia, "é difícil classificar tais entes ou conferir-lhes nome genérico" ${ }^{189}$, motivo pelo qual não adota tal expressão.

Para Lucas Rocha Furtado, em sentido diverso, o "terceiro setor" e "paraestatais" não apresentam conceitos excludentes ${ }^{190}$, pois a entidade do terceiro setor passará a ser também paraestatal quando e se qualificar-se como organização social, OSCIP ou serviços sociais autônomos $^{191}$ (SESI, SENAI, SENAC, SES, SEBRAE ${ }^{192}$ ).

Sem adotar especificamente qualquer das definições supra, interessa-nos verificar as entidades sem fins lucrativos, de interesse público, receptoras de recursos públicos por meio da celebração de parcerias com o Poder Público.

Serão objeto de exame nesta dissertação, portanto, independentemente da titulação ou

\footnotetext{
${ }^{188}$ BRASIL. TCE-SP. MANUAL BÁSICO - Repasses Públicos ao Terceiro Setor. 2007. p 10.

${ }^{189}$ Odete Medauar. (cit.), 2007a. p. 93.

${ }^{190}$ Lucas Rocha Furtado. Curso de Direito Administrativo, (cit.), 2007. p. 227.

${ }^{191}$ Ibid., p. 228.

192 “São pessoas de Direito Privado, sem fins econômicos, criadas por lei para desempenhar atividades assistenciais ou de ensino a determinadas categorias profissionais, e são mantidas com recursos públicos, normalmente arrecadados por meio de contribuições parafiscais. A maior particularidade dessas entidades reside no fato de que são criadas pelo Estado, mas não integram a Administração Pública direta ou indireta. Haja vista serem públicos os recursos que as mantêm, devem prestar contas ao TCU. [...] Como não integram a Administração Pública, não se submetem às exigências da Lei n. 8.666/93; o TCU, todavia, tem obrigado referidas entidades a aprovarem regulamentos próprios que devem ser utilizados para disciplinar suas licitações e contratações". Lucas Rocha Furtado. 2007, p. 232.
}

Este entendimento não é unânime, podendo-se citar Diógenes Gasparini, que entende que estas estão sujeitas ao Tribunal de Contas e "que devem, para realização de seus negócios, observar os princípios da licitação". Direito Administrativo. 7 ed. São Paulo: Saraiva, 2002. p. 384. 
qualificação, todas as entidades privadas sem fins lucrativos voltadas aos interesses nãomútuos e receptoras de recursos públicos por meio de parcerias.

O foco do trabalho, todavia, estará nas parcerias celebradas com as entidades do terceiro setor, pois, por meio delas, muitos recursos públicos são transferidos voluntariamente $^{193}$ e inicia-se o momento de incidência da competência de fiscalização dos Tribunais de Contas sobre elas ${ }^{194}$.

Examinar como o TCU fiscaliza as parcerias e as entidades privadas por sua vez, permite averiguar, em termos práticos, os ideais de contratualização de resultados e a "administração por contratos".

Assim, serão examinados os contratos de gestão, os termos de parceria, o contrato de repasse ou convênio, celebrados respectivamente com as entidades qualificadas como OSs, OSCIPs e outras, pois para as últimas duas espécies de parcerias, não se exige titulação específica, podendo, ainda, as OSs e OSCIPs firmarem estes dois instrumentos.

Utilizar-se-á a legislação federal para versar sobre o tema, por ser a mais debatida na doutrina e por ter maior alcance didático.

No curso da dissertação, serão utilizadas indistintamente as expressões terceiro setor, entidades privadas parceiras, entidades privadas sem fins lucrativos, ONGs, dentre outras, enfocando aquelas receptoras de recursos públicos.

\subsubsection{Atividades do terceiro setor para fins de parceria com o Estado}

\subsubsection{Atividades do terceiro setor}

Em geral, as atividades ${ }^{195}$ desenvolvidas pelo terceiro setor dizem respeito àquelas previstas na Constituição Federal, na qual há previsão de incentivo à colaboração no âmbito social e reconhecimento de inúmeros instrumentos de colaboração participativa com as entidades em comento: no âmbito da saúde (arts. 197 e 198, III), da assistência social (art. 204, I), da educação (arts. 205 e 206), da cultura (art. 216, parágrafo primeiro), do meio

\footnotetext{
${ }^{193}$ Cumpre destacar que as transferências voluntárias a entidades do terceiro setor também poderão se dar por meio de destinação orçamentária específica.

${ }^{194}$ Como se verificará adiante, o controle pelo TCU alcança, muitas vezes, momentos anteriores à celebração de parcerias. Todavia, este controle somente pode ocorrer, a nosso ver, se previamente transferidos recursos públicos à entidade, quando passa a ser gestora de recursos públicos e vincula-se a preceitos de direito públicoadministrativo.

${ }^{195}$ As entidades do terceiro setor não se limitam a prestar serviços, desenvolvendo outras atividades.
} 
ambiente (art. 225), da criança e do adolescente (art. 227, parágrafo primeiro), para mencionar os mais relevantes.

Neste sentido e a título de exemplo, a Lei Federal n. 9.790/99 disciplinou as atividades genericamente previstas na $\mathrm{CF} / 88$ desenvolvidas pelas OSCIPs:

I - promoção da assistência social; II - promoção da cultura, defesa e conservação do patrimônio histórico e artístico; III - promoção gratuita da educação, observando-se a forma complementar de participação das organizações de que trata esta Lei; IV promoção gratuita da saúde, observando-se a forma complementar ${ }^{196}$ de participação das organizações de que trata esta Lei; V - promoção da segurança alimentar e nutricional; VI - defesa, preservação e conservação do meio ambiente e promoção do desenvolvimento sustentável; VII - promoção do voluntariado; VIII - promoção do desenvolvimento econômico e social e combate à pobreza; IX - experimentação, não lucrativa, de novos modelos sócio-produtivos e de sistemas alternativos de produção, comércio, emprego e crédito; X - promoção de direitos estabelecidos, construção de novos direitos e assessoria jurídica gratuita de interesse suplementar; XI - promoção da ética, da paz, da cidadania, dos direitos humanos, da democracia e de outros valores universais; XII - estudos e pesquisas, desenvolvimento de tecnologias alternativas, produção e divulgação de informações e conhecimentos técnicos e científicos que digam respeito às atividades mencionadas neste artigo ${ }^{197}$.

Ressalta-se não haver obstáculo ao desenvolvimento, pelo terceiro setor, de outras atividades não previstas explicitamente na legislação específica relativa a certificações, qualificações, titulações ou fomento. A organização poderá, inclusive, prestar serviços de natureza econômica ${ }^{198}$, não sendo esta sua atividade principal.

\subsubsection{Natureza da atividade e da relação com o Poder Público}

Muito se discute, doutrinariamente, sobre o enquadramento das atividades realizadas pelas entidades privadas sem fins lucrativos em estreita relação com o Poder Público.

Na esteira de Pedro Gonçalves:

[...] a doutrina se questiona, com alguma freqüência, sobre se, no exercício das

\footnotetext{
${ }^{196}$ Em suas auditorias, o TCU tem apontado a distorção da ideia de complementaridade entre a ação pública e de entidades privadas, ao verificar a ocorrência de terceirização ou quarteirização de mão-de-obra. BRASIL. TCU, Acórdão no 402, de 11 de março de 2009. Plenário, p. 17.

${ }^{197}$ Com algumas divergências, nos Estados e Municípios também foram regulamentadas as organizações sociais e OSCIPs. No Estado de São Paulo, por exemplo, as organizações sociais podem desenvolver as atividades de saúde e cultura - em tom mais restritivo que a Lei Federal - e obterem fomento por parte do Estado.

198 “(...) deve ser ressaltado que as entidades sem fins lucrativos podem, evidentemente, obter resultados financeiros positivos; o que lhes é vedado é a transformação de tal resultado, denominado 'superávit', em lucro a ser distribuído a quem quer que seja. Todo o resultado positivo deve ser investido nas finalidades sociais da entidade." Fernando Borges Mânica. Participação privada na prestação de serviços públicos de saúde (cit.), 2009. p. 185
} 
novas tarefas que lhe são confiadas [...] os particulares actuam, por delegação estadual, na execução de uma função pública, ou, antes, no âmbito de uma responsabilidade própria que o ordenamento jurídico lhes comete e, por conseguinte, no exercício de uma actividade privada ${ }^{199}$.

Para Paulo Modesto, as entidades denominadas 'organizações sociais' e de 'utilidade pública ${ }^{200}$, assim como as demais integrantes do terceiro setor a nosso ver, "conquanto privadas, possuem atuação 'pública', 'pública não estatal', 'para-estatal', 'de interesse coletivo', 'de realização do bem comum,"201.

No contexto da "gestão partilhada dos interesses públicos",202 e da perda do monopólio estatal da efetivação dos interesses públicos ${ }^{203}$, as atividades desenvolvidas pelo terceiro setor classificam-se ou integram os "serviços de interesse público"204, "tarefas de interesse público"205 ou "serviços de relevância pública"206 , passíveis de ser prestados pelo privado sem delegação, concessão ou permissão para sua consecução, pertinentes aos serviços públicos,

199 Pedro Gonçalves. Entidades privadas com poderes públicos: o exercício de poderes públicos de autoridade por entidades privadas com funções administrativas (cit.), 2005. p. 140.

${ }^{200}$ Antes da edição da Lei das OSs, “as únicas certificações conferidas às organizações sem fins lucrativos no Brasil eram o Título de Utilidade Pública Federal e o Certificado de Entidade Beneficente de Assistência Social" - CEBAS. O primeiro foi criado pela Lei n. 91 de 1935 e "é concedido às organizações que tenham o fim exclusivo de servir desinteressadamente à coletividade e que promovam a educação ou exerçam atividades científicas, culturais, artísticas ou filantrópicas" e em razão do qual a entidade obtém alguns benefícios. Já o CEBAS é concedido a entidades de assistência social, "assim consideradas as que atuam no sentido de proteger a família, a maternidade, a infância, a adolescência e a velhice; amparar crianças e adolescentes carentes; promover ações de prevenção, habilitação e reabilitação de pessoas portadoras de deficiências; promover, gratuitamente, assistência educacional ou de saúde; e promover a integração ao mercado de trabalho", com o qual a entidade obtém o benefício de isenção de contribuições sociais, dentre elas a do INSS. Valéria Maria Trezza. O termo da parceria como instrumento de relação público/privado sem fins lucrativos: o difícil equilíbrio entre flexibilidade e controle [cit.], 2007, p. 27-29.

Em linhas gerais, o CEBAS é regulado pela seguinte legislação: Art. 195 da Constituição Federal; Lei ${ }^{\circ}$ 8.742, de 7 de dezembro de 1993 (Lei Orgânica da Assistência Social); Art. 55 da Lei no 8.212, de 24 de julho de 1991(Organização e Custeio da Seguridade Social); Lei no 11.096, de 13 de janeiro de 2005 (Lei do Prouni); Lei n ${ }^{\circ} 12.101$ de 27 de novembro de 2009 (Dispõe sobre a certificação das entidades beneficentes de assistência social; regula os procedimentos de isenção de contribuições para a seguridade social e altera legislação correlata); Decreto $\mathrm{n}^{0}$ 2.536, de 6 de abril de 1998 (Dispõe sobre concessão/renovação do certificado) e respectivas alterações previstas nos Decretos n. ${ }^{\circ}$ 3.504/2000, 4.325/2002, 4.381/2002 e 4.499/2002; Resolução CNAS nº 177, de 10 de agosto de 2000 (regras e critérios para concessão/renovação do certificado).

${ }^{201}$ Paulo Modesto. Reforma administrativa e marco legal das organizações sociais no Brasil (cit.), ano 3, n. 30, abr. 1999, p. 7.

202 Pedro Gonçalves. Entidades privadas com poderes públicos: o exercício de poderes públicos de autoridade por entidades privadas com funções administrativas (cit.), 2005. p. 137.

203 Ibid., p. 140.

${ }^{204}$ Fernando Borges Mânica. Terceiro setor e imunidade tributária: teoria e prática (cit.), 2005, p. 63.

${ }^{205}$ Pedro Gonçalves. Entidades privadas com poderes públicos: o exercício de poderes públicos de autoridade por entidades privadas com funções administrativas (cit.), 2005. p. 145.

${ }^{206}$ Márcia Pelegrini. Terceiro setor: gestão privada de recursos públicos. (cit.), jul./dez. 2008, p. 54. 
por não se configurarem como serviço público. O entendimento não é pacífico ${ }^{207}$.

Como lembra Paulo Modesto, não basta prestar serviços ao público, inclusive sem objetivo de lucro, para configurar-se como serviço público ${ }^{208}$. Tampouco "podem ser nomeadas de serviço público atividades desempenhadas por particulares ou por pessoas de direito privado, ainda quando afetem relevantes interesses coletivos, se não foram reservadas pela Constituição da República ou por leis ordinárias ao Estado ou aos seus empregados"209.

O modo de caracterizar a natureza da atuação ${ }^{210}$ dessas entidades em relação ao Estado também é questionado. Uns adjetivam com o vocábulo co-responsável ${ }^{211}$. Outros mencionam o caráter complementar. Há aqueles que utilizam a palavra instrumental ${ }^{212}$, enquanto outros, ainda, adotam o termo substitutivo ${ }^{213}$.

Na senda de Pedro Gonçalves, “o crescimento das missões privadas de prossecução de interesses públicos não se apresenta sempre como o resultado de uma deslocação e privatização

${ }^{207}$ Fernando Borges Mânica, em outra oportunidade, ao versar sobre o contrato de gestão no modelo federal para fins de prestação de serviços de saúde, adotou entendimento diverso do acima exposto: nestes casos haveria a prestação de serviço público como contrato de concessão e não mera prestação de serviço, se as atividades fomentadas forem qualificadas pela Constituição Federal ou lei como serviços públicos e se mantiverem na disciplina contratual as características que as qualificam como tais. Participação privada na prestação de serviços públicos de saúde [cit.], 2009, p. 253.

208 Paulo Modesto. Reforma administrativa e marco legal das organizações sociais no Brasil (cit.), ano 3, n. 30, abr. 1999, p. 12.

${ }^{209}$ Ibid., p.13.

${ }^{210}$ Para Juarez Freitas, “[...] cercadas dos devidos cuidados em termos de controle, as organizações do terceiro setor (é dizer, em sentido amplo, as organizações privadas sem finalidade lucrativa e voltadas a finalidades socialmente relevantes) podem desempenhar um papel precioso na colmatação de lacunas da ação estatal. Todavia, não devem agir de maneira substitutiva ou excludente. Vale dizer, não devem alijar o Estado do cumprimento de suas funções indelegáveis na promoção do núcleo dos direitos fundamentais, mas, sim, desempenhar as tarefas atinentes à esfera de autonomia da sociedade". O controle dos atos administrativos e os princípios fundamentais. 3. ed., rev. ampl. São Paulo: Malheiros, 2004. p. 281.

Ainda, critica José Roberto Pimenta Oliveira: “A utilização do 'terceiro setor' não autoriza, por outro lado, a desconfiguração do Estado Social de Direito consagrado na Constituição Federal, verificada se a atividade de particulares sem finalidade lucrativa assumir velado caráter de substitutividade integral da ação administrativa no setor de atuação, e não verdadeira índole de subsidiariedade. [...] A atividade de fomento é legítima tãosomente se juridicamente estruturada revelar uma técnica de estímulo, não uma técnica de substituição inconstitucional do aparelho administrativo, cuja arquitetura foi delicadamente montada pelo Texto Constitucional". Improbidade Administrativa e Terceiro setor. (cit.), 2008, p.166-167.

211 Segundo Gustavo Justino de Oliveira: "Se é incorreto afirmar que a responsabilidade estatal na execução dessas atividades socialmente relevantes foi integralmente transferida ao setor privado, certo é que ao menos foi incentivada a co-responsabilidade das entidades privadas (mormente as não-lucrativas) para a prática dessas atividades." Estatuto jurídico do Terceiro setor e desenvolvimento: conectividade essencial ao fortalecimento da cidadania à luz dos 20 anos da constituição de 1988 (cit.), 2008a.

212 “[...] seriam somente instrumento do Estado e não seu amplificador ou parceiro”, conforme Maria Tereza Fonseca. Dias. Terceiro setor e Estado: legitimidade e regulação: por um novo marco jurídico, 2008a, p. 93.

${ }^{213}$ Luiz Carlos Bresser Pereira, idealizador do Plano de Reforma do Estado propôs de fato substituição - e não mera complementaridade - do Estado pela sociedade civil naquelas que não sejam de sua atividade exclusiva, ainda que afirme que a "sociedade civil não substitui o Estado, mas cresce e se fortalece com ele". Sociedade e Estado em transformação. (cit.), 1999, p. 91-92. 
material de tarefas públicas". Teoricamente ${ }^{214}$, não substitui a ação do Estado - o que ocorre, na realidade, é um "alargamento das tarefas de proteção de interesses públicos"215.

Não por outra razão, quando desenvolvidas estas tarefas pelo terceiro setor, podem ser objeto de fomento por parte do Estado, inclusive mediante transferência de recursos públicos, em abordagem a ser referida no tópico a seguir.

\footnotetext{
214 “Teoricamente", pois na prática não se pode afirmar com segurança.

215 Pedro Gonçalves. Entidades privadas com poderes públicos: o exercício de poderes públicos de autoridade por entidades privadas com funções administrativas (cit.), 2005. p. 162.
} 


\section{SETOR}

\subsection{Atividade Estatal de Fomento}

O fomento, como "forma de atuação estatal" ${ }^{216}$, tem sido exercido junto ao terceiro setor com o propósito da realização voluntári $a^{217}$ de atividades de interesse público, induzindoo mediante estímulos e incentivos, além de facilitar e orientar sua ação ${ }^{218}$. Das "funções do Estado, a mais afeta ao princípio da subsidiariedade é, por certo, o fomento público ${ }^{219}$."

Dentre as atividades de fomento do $\operatorname{Estado}^{220}$, destacam-se: concessão de títulos honoríficos (utilidade pública), concessão de vantagens tributárias (imunidades e isenções) ${ }^{221}$ e transferência de recursos mediante autorização em lei (por exemplo, orçamentária) ou celebração de parcerias (como convênios, contratos de gestão etc.).

Maria Sylvia Zanella Di Pietro classifica as formas de fomento como: jurídicos (privilégios próprios do Poder Público), honoríficos (títulos, menções honrosas, prêmios, recompensas) e econômicos (isenções fiscais, desapropriações por interesse social, auxílios, subvenções e financiamentos).

Nesta dissertação, serão objeto de exame apenas os instrumentos de fomento pertinentes ao tema, denominados convênios, contratos de repasse, contratos de gestão e termos de parceria, quando envolverem transferências voluntárias de recursos públicos às entidades do terceiro setor a título de subvenção, auxílio ou contribuição.

\footnotetext{
${ }^{216}$ Célia Cunha Mello. O Fomento da Administração Pública. Belo Horizonte: Del Rey, 2003. p. 24.

217 Para Célia Cunha Mello (Ibid., p. 26-27), “A exata compreensão da administração fomentadora demanda, assim, que fiquem evidenciados seus caracteres fundamentais:

a) trata-se de exercício de função administrativa;

b) está voltada à proteção e/ou promoção de seu objeto;

c) há ausência de compulsoriedade;

d) visa a satisfação indireta das necessidades públicas"

218 Silvia Faber Torres. O princípio da subsidiariedade no direito público contemporâneo. Rio de Janeiro: Renovar, 2001. p. 131.

${ }^{219}$ Ibid., p. 164.

220 “Inúmeros são os meios pelos quais a Administração pode realizar a atividade de fomento, sendo, por isso, inviável proceder-se a uma análise exaustiva de todos eles, que podem se revestir de formas as mais variadas, como, por exemplo, isenções e desgravações fiscais, desembolso efetivo, subvenções (meios financeiros), concessão de prêmios (meios honoríficos), propagandas (meios psicológicos) etc.”. (Ibid., p. 167).

${ }^{221}$ Conferir a respeito obra de Célia Cunha Mello. O Fomento da Administração Pública. Belo Horizonte: Del Rey, 2003. p. 107-131.
} 
O conteúdo deste tópico será aprofundado no decorrer da dissertação, já sob a ótica do controle exercido pelo TCU.

\title{
2.1.1 As transferências voluntárias de recursos públicos
}

A transferência de recursos financeiros é de competência do Poder Público, em especial do Poder Executivo, podendo ser diferenciada em transferência voluntária ${ }^{222}$ e transferência obrigatória, esta última decorrente de obrigação constitucional ou legal, segundo Gustavo Justino de Oliveira. ${ }^{223}$

Os títulos sob o quais os recursos são repassados como fomento às entidades em exame são denominados auxílios, contribuições e subvenções sociais, e nem sempre decorrem de instrumentalização de parceria ${ }^{224}$. Tampouco exigem, para sua concessão, qualificação ou titulação específica das entidades sem fins lucrativos.

O "Relatório e Pareceres Prévios sobre as Contas do Governo da República Exercício 2006" 225 , versou sobre o assunto sob o título "Áreas Temáticas 6.1 Transferências voluntárias da União: aspectos relacionados ao controle, programação e execução", dele extraindo-se a seguinte conclusão:

\begin{abstract}
Atualmente, em face do alto grau de vinculações das receitas públicas e da quantidade e valor das despesas obrigatórias em vigor, em torno de $90 \%$ do orçamento da União tem caráter impositivo, apesar do mecanismo de contingenciamento imposto pela LRF (art. $9^{\circ}$ ) ter reforçado explicitamente a opção por um orçamento autorizativo. Os valores de livre alocação, no entanto, não são desprezíveis, situando-se entre R\$ 50 bilhões e R\$ 60 bilhões a cada ano, aproximadamente $11 \%$ do OGU. É nessa fração do orçamento que se acomodam as transferências voluntárias para estados, municípios e ONG, quer as decorrentes de emendas parlamentares quer as integrantes da proposta do Executivo.
\end{abstract}

${ }^{222}$ A Lei de Responsabilidade Fiscal define transferências voluntárias como "a entrega de recursos correntes ou de capital a outro ente da Federação, a título de cooperação, auxílio ou assistência financeira, que não decorra de determinação constitucional ou legal ou se destine ao Sistema Único de Saúde” (art. 25).

${ }^{223}$ Gestão privada de recursos públicos para fins públicos: o modelo das OSCIP. Gustavo Justino de Oliveira. Terceiro setor, empresas e Estado: novas fronteiras entre o público e o privado, 2007b, p. 235.

${ }^{224}$ Ressalta Natasha Salinas que, dentre outras formas de seleção de entidade para recebimento de recursos, pode-se citar a "apresentação de emenda ao OGU por deputado federal ou senador. Neste caso, o nome da entidade e do respectivo projeto a ser custeado com transferências voluntárias já está contemplado no próprio OGU, cabendo ao órgão gestor dos recursos do programa efetuar as referidas análises técnicas em total ausência de competição" Natasha Schmitt Caccia Salinas. Avaliação legislativa no Brasil: um estudo de caso sobre as normas de controle das transferências voluntárias de recursos públicos para entidades do terceiro setor. 2008 [cit.], 2008. p. 78.

${ }^{225}$ Disponível em:

http://portal2.tcu.gov.br/portal/page/portal/TCU/comunidades/contas/contas_governo/CONTAS_ARQUIVOS 2006/CG2006_B1.htm. Acesso em: maio 2009. 


\subsubsection{Subvenção}

As subvenções sociais são conhecidas como transferências correntes, destinadas a instituições públicas ou privadas de caráter assistencial ou cultural, sem finalidade lucrativa, para prestação de serviços essenciais de assistência social, médica ou educacional, em caráter suplementar e unicamente para seu custeio, se as atividades se revelarem mais econômicas.

O valor das subvenções, sempre que possível, será calculado com base em unidades de serviços efetivamente prestados ou postos à disposição dos interessados, obedecidos os padrões mínimos de eficiência previamente fixados (art. 16 da Lei Federal n. 4.320/64). Tais subvenções somente poderão ser concedidas a instituição cujas condições de funcionamento forem julgadas satisfatórias pelos órgãos oficiais de fiscalização, a depender da aferição e certificação pelo poder público, do pleno e regular funcionamento (art. 17).

Dentre outras exigências, o Decreto n. 93.872/86 previu o repasse por meio de rede bancária oficial, e a Instrução Normativa STN n. 01/97 estabeleceu independência da transferência em comento de lei específica, podendo ser efetivada via parceria.

As Leis de Diretrizes Orçamentárias - LDOs também cuidam do assunto e têm sistematicamente alterado o regime do repasse de recursos, como será oportunamente examinado.

Por fim, vale transcrever pensamento de Célia Cunha Mello no contexto deste trabalho:

[...] com a outorga da subvenção, nascem direitos e deveres para o subvencionado, podendo-se destacar como direito principal receber a subvenção na forma outorgada ou contratada, dependendo de sua natureza. [...] Os deveres que, por sua vez, surgem para o subvencionado variam segundo a finalidade que a medida de fomento persegue [...]. Parece, portanto, imprescindível que a administração organize instrumentos mais eficazes de controle da subvenção, de maneira a assegurar a correta utilização dos créditos públicos, sob pena de banir o instituto do ordenamento jurídico pátrio em razão das inúmeras irregularidades que essa técnica tem propiciado na prática administrativa. ${ }^{226}$

\subsubsection{Auxílio}

A Lei Federal n. 4.320/64 (art.12) definiu auxílio como espécie de transferência de capital, que deriva diretamente da Lei do Orçamento, prescindindo de lei especial, com o objetivo de investimentos financeiros e independentemente de contraprestação direta em bens e serviços pela entidade receptora. Já o Decreto Federal n. 93.872/86 (art.63 e seguintes)

\footnotetext{
${ }^{226}$ Célia Cunha Mello. Ofomento da Administração pública (cit.), 2003, p. 104 -107.
} 
previu poder ser destinados a entidades de direito público ou privado, sem finalidade lucrativa, diretamente da Lei de Orçamento.

Além das condições gerais expostas na LDO de 2008, foram previstas condições específicas para concessão de auxílio, como: a) aquisição e instalação de equipamentos, e obras de adequação física necessárias à instalação dos referidos equipamentos; b) aquisição de material permanente; c) reformas e conclusão de obra em andamento, cujo início tenha ocorrido com recursos dos Orçamentos Fiscal e da Seguridade Social, vedada a destinação de recursos para ampliação do projeto original.

\subsubsection{Contribuição}

Para o TCE/SP ${ }^{227}$, a contribuição destina-se a entidades de direito público ou privado, sem finalidade lucrativa, concedida em virtude de lei especial, destinando-se a atender a ônus ou encargo assumido pelo Poder Público, sendo despesa não correspondente à contraprestação direta em bens e serviços, ou seja, reembolsável pelo recebedor.

A Lei Federal $n^{\circ}$ 4.320/64 (art. 12) distinguiu transferência corrente da transferência de capital. Enquanto a primeira se refere às dotações para despesas às quais não corresponda contraprestação direta em bens ou serviços e para atender à manutenção de outras entidades de direito público ou privado, a segunda deriva de lei de orçamento ou de lei especial anterior, para investimento, independentemente de contraprestação direta em bens ou serviços.

Já a LDO 2008 (art. 36) estabeleceu como regra básica a necessidade de autorização legislativa específica (para a contribuição corrente), salvo se tratar-se de transferência a entidades sem fins lucrativos selecionadas para execução, em parceria com a administração pública federal, de programas e ações prioritários que contribuam diretamente para o alcance de diretrizes, objetivos e metas previstas no plano plurianual. Esta seleção deverá ser justificada em ato de autorização da unidade orçamentária transferidora, para cada entidade beneficiária, demonstrando-se o atendimento a todas as exigências legais, e também que a entidade selecionada é a melhor a atender aos critérios estabelecidos para a escolha. Acerca da exigência de lei específica anterior, restringiu para os casos de relativamente às contribuições de capital.

A LDO 2009 alterou o conteúdo da LDO 2008 para estabelecer a obrigação de o ato de autorização conter o critério de seleção, o prazo do convênio ou outro instrumento

\footnotetext{
${ }^{227}$ BRASIL. TCE-SP. Manual básico: repasses públicos ao Terceiro setor, 2007.
} 
congênere, a justificativa para escolha da entidade e as condições aplicáveis aos casos de renovação e prorrogação do acordo.

Em síntese e se somente analisada a Lei n. 4.320, para Sílvio Luís Ferreira da Rocha, enquanto a subvenção destina-se a cobrir despesas de custeio de atividades públicas ou privadas, o auxílio e as contribuições "servem para custear despesas de capital, isto é, aquelas que podem gerar serviços, riquezas, e produzir um incremento ao Produto Nacional”. Já o "auxílio difere das contribuições no que diz respeito ao diploma legislativo. O auxílio deriva diretamente da lei de orçamento ( $\$ 6$ do art. 12 da Lei 4.320) e a contribuição deriva de lei especial". ${ }^{228}$

\subsubsection{Os instrumentos de parceria}

Além das previsões orçamentárias ou leis específicas, a transferência de recursos públicos poderá se dar por meio de parcerias entre o primeiro e o terceiro setor.

As considerações adiante expostas terão por foco esboçar panorama geral sobre os instrumentos de parceria e seus partícipes, sem qualquer pretensão de esgotar o assunto, aprofundando-se o tema oportunamente, quando do exame do exercício do controle pelo TCU.

\subsubsection{Convênio}

Dentre os instrumentos a serem examinados, o convênio configura-se como o mais tradicional e utilizado pela União para viabilizar as transferências voluntárias ao terceiro setor.

O convênio pode ser celebrado entre entes estatais, (art. 71, VI, CF), e entre um destes e entidade privada ( $\operatorname{art} .199, \S 1, \mathrm{CF}$ ), podendo "ter por objeto qualquer coisa (obra, serviço, uso de certo bem), desde que encarne, relacionado a cada partícipe, um interesse público",229. A legislação aplicável, inclusive, é praticamente idêntica para um ou outro caso.

Segundo Gustavo Justino de Oliveira, "no sistema administrativo brasileiro, resta evidenciada a multifuncionalidade do convênio, o qual pode ser encarado tanto como um acordo administrativo organizatório como um acordo administrativo colaborativo" ${ }^{230}$ : o primeiro representa "descentralização de atividades de um órgão ou ente administrativo para outros órgãos ou entes administrativos, da mesma esfera federativa ou de esfera federativa

\footnotetext{
${ }^{228}$ Sílvio Luís Ferreira da Rocha. Terceiro Setor (cit.), 2003. p. 36.

${ }^{229}$ Diógenes Gasparini. Direito Administrativo (cit.), 2002, p. 370.

${ }^{230}$ Gustavo Justino de Oliveira. Contrato de Gestão (cit.), 2008c, p. 269.
} 
distinta"231; o segundo expressa "acordo administrativo colaborativo - firmado entre Administração Pública e particular -, [e] é largamente utilizado para a formação de vínculos de colaboração com quaisquer tipos de entidades privadas, com ou sem fins lucrativos, independentemente de serem detentoras de uma qualificação especial prévia"232.

Debate-se na doutrina se os convênios são $\operatorname{contratos}^{233}$, se, de alguma forma, o regime jurídico destes aplica-se àqueles, ou ainda, se são meros acordos ou "ajustes administrativos" ${ }^{\text {234 }}$ despidos daquela natureza.

Rodrigo Pagani de Souza identificou que os convênios administrativos são definidos na doutrina sob visão "tradicional" 235 (encabeçada por Hely Lopes Meirelles) e outra, por nós denominada, "atual". Segundo o autor, a primeira visão contrasta convênio e contrato ${ }^{236}$, e a segunda amplia a noção de contrato para contemplar convênios, configurando-se relação de "espécie" e "gênero" 237.

Tradicionalmente, na esteira do referido autor e do Tribunal de Contas do Estado de São Paulo (TCE-SP), haveria no convênio: 1) partícipes com interesses, competências ou objetivos institucionais comuns; 2) igualdade jurídica de todos os signatários; 3) ausência de preço ou remuneração ${ }^{238}$; 4) ausência de obrigações recíprocas; 5) possibilidade de denúncia unilateral a qualquer tempo, mantidas as vantagens e responsabilidades existentes até esse momento; 6) ausência de sanções pela inadimplência ${ }^{239}$. Os contratos, por sua vez, tutelariam interesses opostos, um que pretende o objeto do ajuste e o outro meramente a contraprestação.

Como representante da visão "atual" de convênios, cita-se Odete Medauar ${ }^{240}$, Floriano

\footnotetext{
${ }^{231}$ Ibid., p. 269-270.

232 Ibid., p. 269-271.

${ }^{233}$ Tarso Cabral Violin. Terceiro setor e as parcerias com a Administração pública: uma análise crítica. (cit.), 2006. p. 243.

${ }^{234}$ Para Diógenes Gasparini, convênios são ajustes administrativos, e não contratos. Direito Administrativo, cit., 2002, p. 369.

${ }^{235}$ Neste sentido, Lucas Rocha Furtado. Curso de Direito Administrativo, (cit.), 2007. p. 342.

${ }^{236}$ Segundo Paulo Modesto (Reforma administrativa e marco legal das organizações sociais no Brasil $1_{2} 1999$ ) e Diógenes Gasparini (Direito Administrativo, 2002, p. 371).

${ }^{237}$ Conferir a respeito obra de Tarso Cabral Violin. Terceiro setor e as Parcerias com a Administração PúblicaUma Análise Crítica. Belo Horizonte: Fórum, 2006. p. 246.

${ }^{238}$ Domingos Roberto Todero destaca, ainda, que a despeito de não haver preço ou remuneração, poderá ocorrer incremento de aquisição de vantagem, benefício. Dos Convênios da Administração Pública. Dissertação (Mestrado em Direito) - Faculdade de Direito, Pontifícia Universidade Católica do RS, Porto Alegre, 2006. p. 40.

239 Rodrigo Pagani de Souza. Convênios Administrativos de Delegação de Serviço Público de Saneamento Básico: Regime Jurídico. 2006. 200p. Dissertação (Mestrado em Direito) - Faculdade de Direito, Universidade de São Paulo, São Paulo, 2006. p. 71.

${ }^{240}$ Odete Medauar. Convênios e Consórcios Administrativos. Boletim de Direito Administrativo. n. 8, 1995, p. 456.
} 
Azevedo Marques Neto ${ }^{241}$ e Fernando Borges Mânica ${ }^{242}$. Para a autora, haveria no Direito Administrativo "visão genérica do módulo contratual", que abarcaria, dentre outros, os contratos e os convênios, distinguindo-se este daquele pela sua especificidade, "ou por envolver duas ou mais entidades ou órgãos públicos, ou pelo tipo de resultado que se pretende atingir com o acordo firmado". Fernando Borges Mânica classifica os convênios como contratos de fomento, submetendo-os integralmente à Lei Federal n. 8.666/93.

Parece-nos que, aos Tribunais de Contas, a distinção é, sobretudo oportuna, se e na medida em que a utilização da nomenclatura 'convênio' visar burlar a obrigatoriedade de realização de certame para contratação de prestação de serviços, por exemplo. Isto porque a doutrina tem como certa a relevância da distinção entre convênio e contrato, pois “a celebração de convênio não exige a prévia realização de licitação" ${ }^{243}$ - ainda que alguns órgãos realizem "chamadas públicas para selecionar organizações que receberão recursos para execução de algum projeto" 244 . A justificativa para essa assertiva consiste no fato de, "tratando-se de interesses comuns e atendimento de expectativas individuais, não há que se falar em 'melhor proposta', mas apenas em rateio de custos e benefícios entre todos os partícipes" ${ }^{245}$.

Pelo exposto, não nos parece útil adotar cegamente o posicionamento tradicional de

\footnotetext{
241 “Os convênios também são acordos de vontade (contratos em sentido amplo), na medida em que criam obrigações relativas para as partes conveniadas. [...] O que falta aos convênios, e isso os faz distintos dos contratos em espécie e frontalmente diferentes dos contratos administrativos, é a ausência de caráter sinalagmático, de reciprocidade e antagonismo obrigacional. [...] Ainda que possua caráter bilateral, pactual e obrigacional (que os faz integrar uma categoria de atos jurídicos de natureza contratual), os convênios não serão confundíveis com os contratos stricto sensu e muito menos como espécie de contrato administrativo. Se os convênios estabelecem obrigações (ou compromissos) para as partes convenentes, tais obrigações não são tecidas como contrapartidas recíprocas e sim ambas com vistas ao objetivo comum (convenial). Floriano Azevedo Marques Neto. Público e privado no setor de saúde. Revista de Direito Público da Economia RDPE, Belo Horizonte, ano 3, n. 9, p. 105-154, jan./mar. 2005. p. 117.
}

242 “A natureza contratual dos convênios pode ser comprovada por meio da análise da 'teoria dos contratos', tal qual sua construção originaria no direito privado, sua transposição para o direito público e sua atual alocação como categoria da teoria geral do direito. A dicotomia entre contratos e convênios na doutrina brasileira parece ter origem em uma distinção insuficientemente importada do direito privado. [...]. Nesse prisma, entendimentos segundo os quais 'nos contratos há oposição e interesses enquanto nos convênios há convergência de interesses' não revelam visão integral da questão e partem de um pressuposto inexistente, e, porque não dizer, mítico. [...] convênio é, em qualquer hipótese, modalidade de contrato, sua regulamentação deve ocorrer de lei, conforme o já mencionado art. 22, inciso XXVII da Constituição Federal. [...] os convênios como modalidade de 'contratos de fomento' são submetidos à Lei n. 8.666/93”. Fernando Borges Mânica. Participação privada na prestação de serviços públicos de saúde (cit.), 2009, p. 226-231.

${ }^{243}$ Lucas Rocha Furtado. Curso de Direito Administrativo, (cit.), 2007, p. 344.

Maria Sylvia Zanella Di Pietro também esposa entendimento no sentido da inviabilidade de competição e, portanto, da realização de licitação, para fins de celebração de convênio. Temas polêmicos sobre licitações e contratos, (cit.), 2008, p. 344.

${ }^{244}$ Valéria Maria Trezza. O termo de parceria como instrumento de relação público/privado sem fins lucrativos: o difícil equilíbrio entre flexibilidade e controle. (cit.), 2007, p. 59.

${ }^{245}$ Lucas Rocha Furtado. Curso de Direito Administrativo, (cit.), 2007. p. 344. 
efetiva distinção entre convênio e contrato administrativo no novo contexto da administração pública consensual, sobretudo quando constatadas semelhanças do 'contrato de gestão' e 'contrato de repasse' - até mesmo sob alguns aspectos legais - com o 'termo de parceria' e 'convênios'. Há de se verificar, sim, o tratamento jurídico sobre eles incidente, para averiguar os casos de cabimento da realização de certame ${ }^{246}$ ou alguma forma de seleção pública para fins de controle e gestão de recursos públicos.

Interessante notar no Anteprojeto de Lei Orgânica da Administração Pública Federal a adoção da expressão contrato público de colaboração, para abarcar todas as parcerias passíveis de celebração com entidades do terceiro setor, sem distinguir convênios de contratos.

Acerca da legislação aplicável, os convênios são regidos, em especial, pela IN n. 01/97, Lei Federal n. 8.666/93 ${ }^{247}$, Lei Complementar n. 101/2000, Decreto n. 93.872/86, Decreto Federal n. 6.170/07 e alterações e Portaria Interministerial (PI) n. 127/2008 e alterações - legislação a ser examinada oportunamente, quando da análise do exercício de controle pelo TCU. É de se ressaltar que, para Fernando Borges Mânica, convênios seriam contratos de fomento e, por esta razão, somente poderiam ser regulamentados por meio de lei, em cumprimento ao art. 22, XXVII da CF/88.

Arrematando-se, os convênios já foram utilizados como instrumento de repasse de recursos públicos a fundo perdido; mas hoje, seu regime jurídico tem disciplinado inclusive os meios para seu efetivo controle, sobretudo porque o valor repassado ao particular não perde sua natureza de dinheiro público.

\subsubsection{Contrato de repasse}

O contrato de repasse consiste em outro instrumento de fomento estatal. Por seu intermédio, recursos públicos puderam ser repassados às entidades privadas sem fins lucrativos

\footnotetext{
${ }^{246}$ A título de exemplo, apesar das inúmeras controvérsias, o Decreto Federal n. 5.504/05.

${ }^{247} \mathrm{Na}$ exposição de motivos do Anteprojeto de Lei Orgânica da Administração Pública Federal explicitamente a exigência de observância da Lei Federal n. 8.666/93 pelas entidades do terceiro setor é excluída, salvo quando da celebração de convênios, situação para a qual permanece a incidência do art. 116 da citada Lei. Entendemos que se poderia aproveitar a oportunidade para revogar a incidência deste preceito legal sobre os convênios, deixando sua regulação para a legislação específica. Nas notas explicativas do art. 28 do Anteprojeto de Lei do Estatuto do terceiro setor, previu-se que quando entidades dele integrantes forem contratadas para prestar serviços ou fornecer bens ao Poder Público, este deverá instaurar prévio procedimento de licitação, nos termos da Lei Federal n. 8.666/93 - com a ressalva de que neste caso não se trata de parceria. Esta foi conceituada no art. 31 daquele instrumento como "o conjunto de acordos, alianças e convenções múltiplas, firmado entre dois ou mais entes, visando a realização de objetivos de interesse comum, em regime de confiança recíproca e colaboração mútua", podendo ser bilaterais ou multilaterais $(\S 1)$ e envolver transferência de bens e recursos públicos $(\S 2)$.
} 
a partir da previsão constante da LDO para o exercício de $1996^{248}$ por meio de "instituições ou agências financeiras oficiais federais que atuarão como mandatárias da União"249.

Os contratos de repasse "sujeitam-se ao mesmo regime aplicável aos convênios",250, tendo a legislação por meio dele, no entanto, introduzido uma sistemática mais capilarizada para acompanhamento da execução de projetos.

Duas são as etapas necessárias a sua celebração: num primeiro momento, a assinatura de contrato de cooperação entre a União e a instituição financeira no qual são fixados, dentre outros parâmetros, os poderes outorgados à mandatária. Num segundo momento, a instituição financeira estará habilitada a celebrar contratos de repasse com entidades beneficiárias de transferência voluntária. ${ }^{251}$ A Caixa Econômica Federal tem sido a instituição financeira intermediária entre o órgão repassador dos recursos e a entidade privada, tendo por função acompanhar de perto a execução dos serviços prestados por estas.

O contrato de repasse, já previsto no Decreto n. 1.819/96, também sofreu alterações em sua regulação, em especial pela recente PI n. 127/08.

\subsubsection{Contrato de gestão}

A expressão "contrato de gestão" não possui significado jurídico unívoco ${ }^{252}$, podendose, de modo genérico, entendê-lo como aquele celebrado entre entes da Administração ${ }^{253}$ (previsto no $\S 8^{\circ}$ do art. 37 da Constituição Federal ${ }^{254}$ ), entre órgãos da mesma pessoa

${ }^{248}$ Cf. BRASIL. MINISTÉRIO DA FAZENDA; MINISTÉRIO DO PLANEJAMENTO E ORÇAMENTO, Lei 9.082/1995, art. 18, § 4 e art. 111.

${ }^{249}$ Gustavo Justino de Oliveira. Terceiro setor, empresas e Estado: novas fronteiras entre o público e o privado, (cit.), 2007b. p. 253.

250 "Observa-se que o contrato de repasse é muito semelhante ao convênio. A grande diferença entre os dois reside em que, no contrato de repasse, existe a intermediação realizada por instituição ou agente financeiro público federal, atuando como mandatário da União". cf. Guilherme Henrique de La Rocque Almeida. Controle das Transferências Financeiras da União. Belo Horizonte: Fórum, 2008b. p. 261.

251 Natasha Schmitt Caccia Salinas. Avaliação legislativa no Brasil: um estudo de caso sobre as normas de controle das transferências voluntárias de recursos públicos para entidades do terceiro setor (cit.), 2008. p. 88.

252 "Mostra-se razoável justificar tamanha diversidade pelo caráter ambíguo da lei em tela, uma vez que, na doutrina, se está longe de ver pacificado, ou melhor, longe de se encontrar um entendimento, sequer majoritário, acerca do que sejam as organizações sociais". Ataliba Pinheiro Espírito Santo. As organizações sociais e a Reforma Administrativa, Revista de Direito Administrativo, Rio de Janeiro, vol. 230, out./dez. 2002. p. 84.

${ }^{253}$ Lucas Rocha Furtado. Curso de Direito Administrativo, (cit.), 2007. p. 348.

${ }^{254}$ Gustavo Justino de Oliveira define este contrato de gestão como sendo um instrumento "por meio do qual são ampliadas as autonomias gerencial, orçamentária e financeira dos órgãos e entidades da Administração Pública, com a estipulação de metas de desempenho e fixação negociada de resultados, os quais deverão ser atingidos a partir da execução de uma série programada de atos (programação derivada), cuja finalidade é conferir efetividade a planos, programas e políticas públicas (programação originária), promovendo assim a 
jurídica $^{255}$, ou aquele firmado como acordo colaborativo entre ente da Administração Pública e entidades qualificadas como organizações sociais - OSs (previsto na Lei Federal n. 9.637/98, legislação Estadual e Municipal), interessando-nos o exame deste último.

Para os fins deste trabalho, "o Contrato de Gestão é o instrumento pelo qual o Estado relaciona-se com as Organizações Sociais com vistas à formação de parcerias para fomento e execução de atividades" 256 e regulamentação de seu controle.

A Lei 9.637/98 permite a qualificação como OSs de instituições dirigidas ao ensino, à pesquisa científica, ao desenvolvimento tecnológico, à proteção e preservação do meio ambiente, à cultura e à saúde. Após esse enquadramento, “a entidade estará habilitada a receber recursos públicos financeiros e administrar bens, equipamentos e pessoal do Estado $^{257}$ que assegurem a qualidade e a efetividade dos serviços prestados ao público"258 mediante contrato de gestão ${ }^{259}$. Este deverá especificar o programa de trabalho, as metas a serem atingidas que assegurem a qualidade e efetividade dos serviços prestados e o prazo para tal, bem como os critérios objetivos de avaliação de desempenho, com indicadores de qualidade e produtividade.

Em outras palavras, uma vez celebrado o contrato de gestão, a entidade poderá receber recursos públicos previstos no orçamento e liberados em consonância ao cronograma previsto na avença ${ }^{260}$, bem como móveis, imóveis e semoventes para desenvolver suas atividades ${ }^{261} \mathrm{e}$ servidores públicos ${ }^{262}$. Não haverá necessidade de habilitar-se ao recebimento de subvenções

eficiência na gestão pública”. Contrato de Gestão (cit., 2008c, p. 185-186).

${ }^{255}$ No anteprojeto de Lei Orgânica da Administração Pública Federal optou-se pela denominação "contrato de autonomia" em substituição ao "contrato de gestão" para os casos de contratualização de controle de entidade pública, deixando para a parceria público-privada com organização social a nomenclatura "contrato de gestão".

${ }^{256}$ Conforme Valéria Maria Trezza. O termo da parceria como instrumento de relação público/privado sem fins lucrativos: o difícil equilíbrio entre flexibilidade e controle, (cit.), 2007, 61-62.

${ }^{257}$ Segundo Caio Tácito: “Os contratos de gestão, em suas diversas variantes, consagram-se como o instrumento formal por excelência dos programas de reforma administrativa, moldada na definição de metas de desempenho e na avaliação de resultados". A reforma do Estado e a modernidade administrativa (cit.), 1999, p.7.

${ }^{258}$ Valéria Maria Trezza. O termo da parceria como instrumento de relação público/privado sem fins lucrativos: o difícil equilíbrio entre flexibilidade e controle, (cit.), 2007, 61-62.

${ }^{259}$ Vale mencionar que também pode ser celebrado com entidades qualificadas como "serviços sociais autônomos, ou que tenham recebido delegação do Conselho Nacional de Recursos Hídricos - CNRH para exercer funções de competência das Agências de Águas (art. 1. da Lei Federal 10.881/2004)". Gustavo Justino de Oliveira. Contrato de Gestão, cit., 2008c, p. 271.

${ }^{260}$ Karine Borges Goulart. As Organizações Sociais. Revista da Procuradoria Geral do INSS. Brasília, vol. 8, n. 4, p. 17-36, jan./mar. 2002. p. 32.

${ }^{261}$ Diógenes Gasparini. Direito administrativo (cit.), 2002. p. 387.

${ }^{262}$ Gustavo Justino de Oliveira. Contrato de Gestão. (cit.), 2008c. p. 280. 
sociais, como fazem as entidades de utilidade pública ${ }^{263}$.

Comparados pela doutrina os institutos "convênios" e "contratos de gestão", estes "constituem relações dotadas de maior estabilidade e, em regra, geram efeitos vinculantes para as partes", sendo que "tendem a serem executados integralmente, uma vez que os resultados a ser alcançados são parte integrante do ajuste", sob pena até de desqualificação da entidade como $\mathrm{OS}^{264}$.

No contrato de gestão, se estabelecem objetivos e metas, com indicadores de desempenho previamente fixados de modo claro e objetivo, com controle de resultados ou finalístico, em substituição ao "tão criticado controle dos processos" ${ }^{265}$. Convém destacar, na esteira de Lucas Rocha Furtado, que “a concepção das organizações sociais apresenta-se indissociável da ideia de controle externo de resultados, periódico e aposteriori, tendo por fim a verificação do cumprimento do contrato de gestão"266 .

Assim, tal contrato seria instrumento com a pretensão de aprimorar a gestão de recursos públicos por entidades do terceiro setor a fim de torná-la mais flexível e condizente com a Administração Pública Gerencial, buscando viabilizar o alcance de resultados nele previstos.

O exame da legislação e seus mecanismos de controle dos contratos de gestão serão aprofundados adiante. Todavia, faz-se oportuno tecer considerações sobre as críticas ${ }^{267}$ doutrinárias e os posicionamentos antagônicos acerca das OSs, em especial o modelo federal ${ }^{268}$, tendo como pano de fundo a "preocupação com a preservação do patrimônio

${ }^{263}$ Karine Borges Goulart. As organizações sociais, (cit.), 2002. p. 32.

${ }^{264}$ Gustavo Justino de Oliveira. Contrato de Gestão, (cit.), 2008c. p. 271.

${ }^{265}$ Celso R. Bastos e André R. Tavares também apontam para o acompanhamento e avaliação do contrato de gestão de modo concomitante, com "mecanismos de acompanhamento e avaliação" que "sinalizam um efetivo controle dos resultados durante a sua vigência”. As Tendências do Direito Público. São Paulo: Saraiva, 2000, p. $289-291$.

${ }^{266}$ Ibid., p. 296.

Lucas Rocha Furtado. Curso de Direito Administrativo, (cit.), 2007. p. 347.

${ }^{267}$ Foram propostas duas Ações Diretas de Inconstitucionalidade, em tramitação no Supremo Tribunal Federal: Adin. n. 1.923-DF, cuja medida liminar foi indeferida, e Adin. n. 1.943-DF em face da citada Lei Federal n. 9.637/98, que tratou das Organizações Sociais, sendo que a primeira foi objeto de comentários de Gustavo Justino de Oliveira. Comentários à Medida Cautelar da Adin n. 1.923-DF, do Supremo Tribunal Federal. Revista de Direito do Terceiro Setor, Belo Horizonte, ano 1, n. 2, p. 177-210, jul./dez. 2007c.

268 Várias das críticas às organizações sociais federais não se aplicam, por exemplo, ao modelo da Lei Complementar n. 846/98 do Estado de São Paulo - alterada e complementada pela Lei Complementar n. 1095/2009, "que quase se pode falar que se trata de outro tipo de entidade, embora a denominação de organização social seja a mesma adotada na esfera federal" (Maria Sylvia Zanella Di Pietro. Parcerias na Administração Pública - Concessão, Permissão, Franquia, Terceirização, Parceria Público-Privada e outras Formas. 6 ed. São Paulo: Atlas, 2008. p. 266). As organizações sociais paulistas originalmente não decorriam da extinção de entidade pública, tampouco possuem representantes do Poder Público em seus órgãos de administração, para citar algumas distinções. Este diverge do modelo federal, seja porque restringe os campos 
público"269 e sua previsão no contexto da Reforma do Estado, pois nesta eram claros os objetivos de transformação de entidades públicas em privadas ${ }^{270}$.

Há discussões quanto à inserção das OSs no âmbito do terceiro setor ${ }^{271}$, sobretudo por conta da previsão de interferência pública em sua qualificação ${ }^{272}$, composição $^{273}$ e atuação,

de atuação, seja porque exige cinco anos de existência da entidade antes de sua qualificação, não autoriza às prestadoras de serviços de saúde o recebimento de bens e servidores públicos para execução de suas atividades, tampouco como integrantes de seu conselho de administração.

${ }^{269}$ Odete Medauar. Direito Administrativo Moderno (cit.), 2007a, p. 97.

270 “Transferir para o setor público não-estatal esses serviços, através de um programa de 'publicização', transformando as atuais fundações públicas em organizações sociais, ou seja, em entidades de direito privado, sem fins lucrativos, que tenham autorização específica do Poder Legislativo para celebrar contrato de gestão com o Poder Executivo e, assim, ter direito a dotação orçamentária; Lograr, assim, uma maior autonomia e uma conseqüente maior responsabilidade para os dirigentes desses serviços; Lograr adicionalmente um controle social direto desses serviços por parte da sociedade através dos seus conselhos de administração. Mais amplamente, fortalecer práticas de adoção de mecanismos que privilegiem a participação da sociedade tanto na formulação quanto na avaliação do desempenho da organização social, viabilizando o controle social; Lograr, finalmente, uma maior parceria entre o Estado, que continuará a financiar a instituição, a própria organização social, e a sociedade a que serve e que deverá também participar minoritariamente de seu financiamento via compra de serviços e doações; Aumentar, assim, a eficiência e a qualidade dos serviços, atendendo melhor o cidadão-cliente a um custo menor". BRASIL. PRESIDÊNCIA DA REPÚBLICA. CÂMARA DA REFORMA DO ESTADO, Plano Diretor da Reforma do Aparelho do Estado, 1995.

O termo publicização, todavia, também é entendido como a retirada pelo Estado do setor privado e reforço de seus instrumentos regulatórios das atividades delegadas, enquanto a privatização, como a execução de atividade pelo privado quando o interesse público puder ser mais bem realizado por este meio. (Diogo de Figueiredo Moreira Neto. Mutações do Direito Administrativo, 2001, p. 40).

A respeito, Odete Medauar assim pronunciou-se: “Com a dinâmica intervencionista o Estado passou a atuar em esferas antes tidas como reservadas à autonomia privada, em especial no setor econômico e social, do que resultou o processo denominado de publicização do privado; o que afetava a poucos passou a ser de interesse comum; a política interferiu na economia; por outro lado, grandes organizações, associações e grupos privados passaram a exercer pressão sobre o Estado, a colaborar na gestão de atividades de interesse geral, a solucionar problemas mediante acordos e negociações, gerando a chamada privatização do público". O Direito Administrativo em Evolução, [cit.] 2003, p. 115

${ }^{271}$ Citam-se os autores que incluem as organizações sociais no terceiro setor:

- Paulo Modesto. Reforma Administrativa e marco legal das organizações sociais no Brasil, 1999. Disponível em: http://jus2.uol.com.br/doutrina/texto.asp?id=473. Acesso em: 06 mar. 2008. p. 4);

- Celso Ribeiro Bastos e André Ramos Tavares. As Tendências do Direito Público. São Paulo: Saraiva, 2000. p. 291;

- Luis Eduardo Patrone Regules. Notas Sobre os Princípios Constitucionais da Administração Pública e as Organizações do Terceiro setor. In: Darlan Barroso; et al. Direito Constitucional: temas atuais. São Paulo: Método, 2007, p.114.

- Karine Borges Goulart. As Organizações Sociais. Revista da Procuradoria Geral do INSS. Brasília, vol. 8, n. 4, p. 17-36, jan./mar. 2002. p.21.

Em sentido contrário, cita-se Gustavo Justino de Oliveira. Contrato de Gestão. São Paulo: Revista dos Tribunais, 2008c. p. 278.

272 A forma discricionária como é concedida a qualificação de organização social é criticada, dentre outros autores, por José Adércio Leite Sampaio. As Organizações Sociais. Revista de Direito do Estado, ano 2, n. 7, p. 273-287, jul./set. 2007.

${ }^{273}$ Segundo o art. 2, inciso I, alínea $d$ da Lei Federal n.9.637/98, são requisitos específicos para que as entidades previstas no artigo anterior habilitem-se a qualificação como OS: "previsão de participação, no órgão colegiado de deliberação superior, de representantes do Poder Público e de membros da comunidade, de notória capacidade profissional e idoneidade moral". 
fazendo com que "operem numa lógica "quase-governamental"274. Para o TCE-SP todavia, esta interferência em nada prejudica a sua classificação como integrante de tal setor ${ }^{275}$. Ainda, o fato de decorrerem ou não exclusivamente da extinção de ente estatal ou de atuarem de modo complementar ou substitutivo ao Estado $^{276}$ também têm sido motivos de questionamento acerca da inclusão das OSs no terceiro setor.

Outrossim, para alguns, a implementação do contrato de gestão e das OSs caminharia em sentido contrário ao ideal das parcerias ${ }^{277}$, por visarem a substituição do Estado e não a complementaridade ou colaboração em suas atividades, bem como "só excepcionalmente o contrato de gestão ser 'elaborado de comum acordo', representando uma composição bilateral" 278 .

O tema interessa ao presente trabalho porque tais disparidades de entendimento implicaram tratamento oscilante pelas Cortes de Contas, ao se filiarem a uma ou a outra linha, como será oportunamente explanado.

Ademais, há autores que classificam as OSs como entidades privadas ${ }^{279}$, outros

De acordo com José Adércio Leite Sampaio, “A presença significativa de representantes do Poder Público, para alguns, é injustificada interferência do Estado na organização civil, que deve ser ignorada pelos legisladores dos outros entes federativos ao editarem suas leis sobre o assunto", As Organizações Sociais. Revista de Direito do Estado, ano 2, n. 7, p. 273-287, jul./set. 2007. p. 278.

274 Natasha Schmitt Caccia Salinas. Avaliação legislativa no Brasil: um estudo de caso sobre as normas de controle das transferências voluntárias de recursos públicos para entidades do terceiro setor, (cit.), 2008 , p. 79.

${ }^{275}$ Para o Tribunal de Contas do Estado de São Paulo, as organizações sociais integram o terceiro setor em que pese definir o contrato de gestão como aquele celebrado com estas "condicionados inicialmente à transferência e ao aceite da execução de serviços públicos preexistentes, previstos em Lei”. Em resumo, segundo aquela Corte, "tal ajuste destina-se a transferir gestão de atividade, órgão ou entidade pública para a iniciativa privada; porém, apenas para entes que possuam capacitação comprovada pela Administração Pública [...]”. BRASIL. TCE-SP. Manual Básico: repasses públicos ao Terceiro setor. 2007. p. 79.

${ }^{276}$ No sentido de que a contratação das organizações sociais visaria ou poderia visar o trespasse de atividade pública para privada, citam-se:

- Floriano de Azevedo Marques Neto. Público e privado no setor de saúde. Revista de Direito Público da Economia - RDPE, Belo Horizonte, ano 3, n. 9, p. 105-154, jan./mar. 2005. p. 131;

- Maria Sylvia Zanella Di Pietro. Parcerias na Administração Pública - Concessão, Permissão, Franquia, Terceirização, Parceria Público-Privada e outras Formas. 6 ed. São Paulo: Atlas, 2008. p. 262;

- Juarez Freitas. Regime Peculiar das Organizações Sociais e o Indispensável Aperfeiçoamento do Modelo Federal. Revista de Direito Administrativo, Rio de Janeiro, n. 214, p. 99-106, out./dez. 1998. p. 99; e

- Sérgio de Andréa Ferreira. Uma Visão Crítica das Organizações Sociais. Revista Trimestral de Direito Público, n. 25. p. 36., 1999.

277 “Apesar de ser intenção do Programa de Reforma Administrativa gerencial possibilitar uma parceria muito mais efetiva entre sociedade e Estado, a participação popular não está explícita nos instrumentos que instituíram as regras de criação das OSs [...]". Maria Tereza Fonseca Dias. Direito Administrativo PósModerno. Belo Horizonte: Mandamentos, 2003. p. 243.

${ }^{278}$ Egon Bockmann Moreira. Organizações Sociais, Organizações da Sociedade Civil de Interesse Público e seus "vínculos contratuais" com o Estado. Fórum Administrativo - Direito Público - FA, Belo Horizonte, ano 6, n. 62, p. 7085-7092, abr. 2006. p. 7090.

${ }^{279}$ Além da definição na própria Lei Federal n. 9.637/98, autores como Sérgio de Andréa Ferreira defendem a 
como uma espécie de "entidade paraestatal" 280 , entidade estatal da administração indireta ${ }^{281}$, de caráter autárquico ${ }^{282}$ ou fundacional, de "novos serviços sociais autônomos" consignam obedecerem as OSs a regime sui generis por decorrerem de processo denominado publicização ${ }^{284}$ ou de processo de privatização. A depender do ponto de vista, transformadas em organizações qualificadas como sociais ou entidades privadas qualificadas como tal, as entidades públicas federais passam a prestar serviços de interesse público - ou até mesmo serviço público.

As OSs, dotadas de personalidade de direito privado, sem fins lucrativos, sob a formatação jurídica de fundação, associação ou cooperativa ${ }^{285}$, ou somente fundação ou $\operatorname{associação~}^{286}$, foram previstas no Plano Diretor da Reforma do Estado $^{287}$ para fins de prestação de serviços públicos não-estatais (universidades e hospitais públicos, centros de pesquisa, bibliotecas e museus) e decorrentes de processo publicização.

Arrematando-se a questão, para Paulo Modesto, as OSs não "são um novo tipo de pessoa jurídica nem entidades criadas por lei e encartadas na estrutura da administração

natureza privada das organizações sociais. Uma Visão Crítica das Organizações Sociais. Revista Trimestral de Direito Público, n. 25. p. 33-42. 1999.

${ }^{280}$ Conforme destacado por Gustavo Justino de Oliveira. Contrato de Gestão. São Paulo: Revista dos Tribunais, 2008. p. 280.

281 Conforme aponta, mas não concorda, Paulo Modesto. Reforma Administrativa e marco legal das organizações sociais no Brasil. Disponível em: http://jus2.uol.com.br/doutrina/texto.asp?id=473. Acesso em: 06 mar. 2008. p. 6.

${ }^{282}$ Mencionado por Perpétua Ivo Valadão e Paulo Moreno Carvalho, ainda que adotem o entendimento de que se trata de pessoas jurídicas de direito privado "em cooperação/colaboração com a administração pública". Organizações Sociais: Processo Seletivo Para Firmar Contrato de Gestão. In: Guilherme José Purvin Figueiredo; José Nuzzi Neto. Temas de Direito Constitucional: Estudos em homenagem ao advogado público André Franco Montoro. Rio de Janeiro: Esplanada-IBAP, 2000, p. 342.

${ }^{283}$ Maria Coeli Simões Pires. Terceiro setor e Organizações Sociais, Boletim de Direito Administrativo, ano XV, n. 4, abril, p. 245-255. 1999. p. 248.

${ }^{284}$ Sílvio Luís Ferreira da Rocha esclarece: “A proposta do Plano Diretor da Reforma do Aparelho do Estado completa-se com a admissão, ao lado da propriedade estatal e da propriedade privada, da denominada propriedade pública não-estatal de bens e serviços, a ser titularizada pelas organizações sem fins lucrativos. Ao setor de serviços não-exclusivos de atuação do Estado deve corresponder a propriedade pública não-estatal e, por essa razão, bens e serviços de titularidade do Estado são transferidos a organizações sem fins lucrativos e de direito privado por intermédio de um processo denominado "publicização". Terceiro Setor. Temas de Direito Administrativo - 7. São Paulo: Malheiros, 2003. p. 83.

${ }^{285}$ Fernando Borges Mânica. Terceiro setor e imunidade tributária: teoria e prática (cit.), 2005, p. 48.

${ }^{286}$ Paulo Modesto. Reforma administrativa e marco legal das organizações sociais no Brasil (cit.), ano 3, n. 30, abr. 1999, p. 4.

287 "No discurso oficial, a 'implementação de Organizações Sociais [tornara-se] uma estratégia central do Plano Diretor de Reforma do Aparelho do Estado'. A estratégia de publicização, entendida como a produção nãolucrativa pela sociedade de bens ou serviços públicos não-exclusivos de Estado, mediante utilização flexível de recursos com ênfase nos resultados, visava, exatamente, a aumentar a eficiência e a qualidade dos serviços, atendendo melhor o cidadão-cliente a menor custo". José Adércio Leite Sampaio. As Organizações Sociais. Revista de Direito do Estado, ano 2, n. 7, p. 273-287, jul./set. 2007. p. 276. 
pública”, "não são criaturas do Estado, nem sucessoras necessárias de entidades públicas extintas", mas são fundações ou associações que possuem um "título jurídico especial 288 conferido pelo Poder Público em vista do atendimento de requisitos gerais de constituição e funcionamento previstos expressamente em lei”, "independentemente da extinção de qualquer ente público existente ${ }^{, 289}$. É dizer, podem ${ }^{290}$ ou não advir de entidade pública extinta, como nascedouro de organização social.

\subsubsection{Termo de parceria}

Os termos de parceria são instrumentos jurídicos, celebrados entre entes de Administração Pública e pessoas jurídicas privadas sem fins lucrativos, qualificadas pelo Estado como OSCIPs, a título de "formação de vínculo de cooperação"291 e repasse de recursos públicos "para o fomento e a execução das atividades de interesse público desempenhadas pelas mesmas" ${ }^{292}$. A sua introdução no ordenamento jurídico brasileiro pela Lei Federal n. 9.790/99 deu-se no "contexto no qual se buscou uma reforma ampla do marco legal do terceiro setor ${ }^{\prime 293}$.

As organizações qualificadas como OSCIPs possuem formatação jurídica de “associações ou fundações privadas integrantes do terceiro setor, não sendo consideradas

${ }^{288}$ Paulo Modesto elaborou quadro comparativo entre organizações sociais e entidades privadas declaradas de utilidade pública. Reforma do Marco Legal do Terceiro Setor no Brasil. Disponível em: http://www.bresserpereira.org.br/Terceiros/Autores/Modesto,Paulo/terceirosetorreforma.PDF. (Acesso em: 02 set. de 2009).

289 Ambas as citações extraídas do artigo de Paulo Modesto. Reforma administrativa e marco legal das organizações sociais no Brasil (cit.), ano 3, n. 30, abr. 1999.

${ }^{290}$ Destaca Lucas Rocha Furtado que a intenção da Lei 9.637/98 de extinguir determinadas entidades públicas e de criar em seu lugar entidades privadas seria inconstitucional, visto que o Estado somente pode criar autarquias, fundações públicas, empresas públicas e sociedade de economia mista (art. 37, XIX), assim como subsidiárias destas (art. 37, XX), não podendo, portanto, "criar entidade que não seja integrante da Administração Pública indireta”. Curso de Direito Administrativo, cit., 2007. p. 230.

${ }^{291}$ Odete Medauar. O Direito Administrativo em Evolução (cit.), 2003, p. 215.

292 Odete Medauar. Direito Administrativo Moderno (cit.), 2007a. p. 232

${ }^{293}$ Natasha Schmitt Caccia Salinas. Avaliação legislativa no Brasil: um estudo de caso sobre as normas de controle das transferências voluntárias de recursos públicos para entidades do terceiro setor (cit.), 2008. p. 88. Vide a respeito do desempenho do Conselho da Comunidade Solidária e as rodadas de interlocução política.

De acordo com Luziânia C. Pinheiro Braga, "na tentativa de simplificar tal titulação [utilidade pública], bem como lhe dar maior transparência, surgiu uma nova legislação mais afeiçoada com as aspirações sociais emergentes. A noção de 'terceiro setor' vai, gradativamente, descolando-se da noção de filantropia, assistência social, caridade, para atingir uma conformação mais abrangente". Organizações da Sociedade Civil de Interesse Público (OSCIPs) - Promoção e Construção de (Novos) Direitos e Assessoria Jurídica de Caráter Suplementar. Fórum Administrativo - Direito Público - FA, Belo Horizonte, ano 5, n. 57, p. 6393-6401, nov. 2005. p. 6395. 
entidades paraestatais $" 294$.

A doutrina não é unânime quanto à natureza das OSCIPs e dos termos de parceria, bem como suas distinções em relação aos demais instrumentos.

De acordo com Gustavo Justino de Oliveira, os termos de parceria são da mesma natureza do contrato de gestão, qual seja, "acordos administrativos colaborativos, ajustados

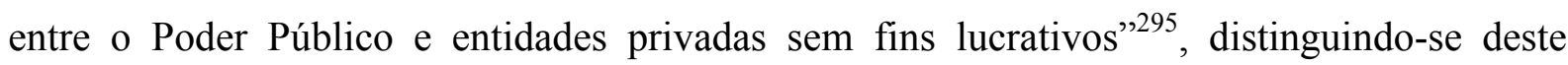
apenas em razão do seu regime jurídico ${ }^{296}$.

Para Lucas Rocha Furtado, comparadas a legislação relativa às OSCIPs e às OSs, "salvo pequenos detalhes procedimentais, não é possível identificar distinções entre uma e outra entidade", dificuldade estendida, em consequência, ao contrato de gestão e termo de parceria $^{297}$, nos quais não se pode perceber, de acordo com o autor, a razão da existência desses dois modelos ${ }^{298}$. A diferença entre eles estaria no alcance de cada um: o contrato de gestão seria mais amplo e alcançaria todas as atividades da entidade, enquanto o termo de parceria teria por fim apenas obter ajuda do poder público para desenvolver alguma atividade ou projeto de interesse público, que teria a combinação com recursos próprios ou de terceiros ${ }^{299}$, "sem comprometer a autonomia ou independência da OSCIP"300.

As OSCIPs e os termos de parceria, ainda, comparativamente às OSs e aos contratos de gestão, seriam mais condizentes com a Administração Pública Consensual e terceiro setor, seja porque independentes da ingerência direta da Administração Pública por meio de servidores em seus quadros, seja pelo recebimento de recursos públicos mediante celebração daquele instrumento para fins de alcance de certos resultados de interesse público que, a princípio, seriam objeto de definição e elaboração conjunta ou negociada.

Comparando o termo de parceria com o convênio, Lucas Rocha Furtado também os

\footnotetext{
${ }^{294}$ Gustavo Justino de Oliveira. Contrato de Gestão. São Paulo: Revista dos Tribunais, 2008c. p. 280.

295 Ibid., p. 278.

${ }^{296}$ Ibid., p. 279.

${ }^{297}$ Lucas Rocha Furtado. Curso de Direito Administrativo, (cit.), 2007. p. 349.

${ }^{298}$ Ibid., p. 231.
}

Neste sentido, Fernando Borges Mânica diz: “[...] a disciplina legal dos termos de parceria em muito se assemelha à dos contratos de gestão, de modo que as observações acerca daquele modelo de ajuste podem, em grande medida, ser aplicados aos serviços de saúde prestados por meio de termos de parceria." Note-se que o autor adota entendimento de que os serviços de saúde prestados por meio de contrato de gestão seriam serviços públicos e de que a Lei aplicável para seleção da OSs seria a Lei de Concessões. Participação privada na prestação de serviços públicos de saúde. (cit.), 2009, p. 262.

${ }^{299}$ Lucas Rocha Furtado. Curso de Direito Administrativo, (cit.), 2007. p. 349-350.

${ }^{300}$ Ibid., p. 231. 
considera muito próximos, distinguindo-os apenas por seu objeto: no convênio, este seria definido pelo tempo (ex. construção de hospital), ao passo que nos termos de parceria, o objeto seria por prazo indeterminado (ex. manutenção de reserva ambiental ${ }^{301}$ ), a despeito de o termo de parceria ter prazo determinado. Por ser a distinção sutil, todavia, entende que um poderia ser utilizado no lugar do outro, com a observância do regime de cada um no caso concreto $^{302}$.

Segundo Valéria Maria Trezza, os termos de parceria distinguem-se do convênio nos aspectos de flexibilidade e mecanismos de controle, dentre outras razões pelo fato de: o convênio originar-se da relação entre órgãos públicos, desconsiderando as especificidades do terceiro setor; os termos de parceria possuírem maior flexibilidade na aplicação dos recursos, tendo por foco a avaliação de resultados e desempenho, e não apenas a forma de aplicação dos recursos; os mecanismos de controle dos convênios serem muito rígidos, avaliando o controle da destinação do orçamento e da entrega formal de documentação, e não a efetividade e eficiência das ações finais; haver nos termos de parceria critérios mais claros e transparentes de prestação de contas e de controle de resultados, bem como a previsão de punição severa em caso de uso indevido de recursos públicos, com responsabilização do gestor, devolução dos recursos e desqualificação da organização. A autora observa, ainda, que há "significativas diferenças na forma como cada órgão tem aplicado o instrumento na prática, proporcionando mais ou menos vantagens" 303 a um ou a outro.

Sob os aspectos legais, o termo de parceria encontra-se previsto na Lei Federal $\mathrm{n}$. 9.790/99 $9^{304}$, no Decreto n. 3.100/99 e na Portaria MJ n. 361/99 $9^{305}$, sendo passível, como se viu, de ser celebrado especificamente com entidades qualificadas como OSCIP, contendo a previsão de programa de trabalho (proposto pela entidade), metas e resultados a serem atingidos, prazos de execução, critérios objetivos de avaliação de desempenho a serem utilizados como indicadores de resultado e a previsão de receitas e despesas para o seu cumprimento.

\footnotetext{
${ }^{301}$ A título de exemplo, convém mencionar que a Lei Federal 9.985/2000 criou o Sistema Nacional de Unidades de Conservação Ambiental, tendo previsto que OSCIP poderá gerir unidades de conservação, desde que tenha objetivos afins aos da unidade e mediante celebração de instrumento com o órgão responsável por sua gestão. O procedimento para sua efetivação consta do Decreto 4.340/2002, que previu seleção da OSCIP por meio de publicação de edital.

${ }^{302}$ Lucas Rocha Furtado. Curso de Direito Administrativo, (cit.), 2007. p. 231.

${ }^{303}$ Valéria Maria Trezza. O termo de parceria como instrumento de relação público/privado sem fins lucrativos: o difícil equilíbrio entre flexibilidade e controle. (cit.), 2007, p. 66-69.

304 Em São Paulo, a Lei Estadual n. 11.598/2003 não previu a qualificação de OSCIP pelo Estado, mas disciplinou os termos de parceria a serem com elas firmados.

${ }^{305}$ E nas leis estaduais ou municipais que tenham disciplinado a matéria no âmbito de sua competência, como são exemplos a Lei n. 11.743/00 do Estado de Pernambuco, a Lei n. 11.598/03 do Estado de São Paulo e a Lei n. 14. 870/03 do Estado de Minas Gerais.
} 
Por fim, interessante notar o universo federal das OSCIPs de mais de $5.200^{306}$, num contexto nacional de cerca de 340 mil ONGs, segundo o IBGE. Mesmo que nem todas as ONGs celebrem convênios com o Poder Público, eles são em maior número do que a quantidade de OSCIPs e OSs e respectivos instrumentos de parceria, motivo pelo qual se ratifica a necessidade de examiná-lo minuciosamente e não somente os termos de parceria e contratos de gestão. Ademais, vale considerar que OSCIPs e OSs também podem celebrar convênios.

306 BRASIL. MINISTÉRIO DA JUSTIÇA, Consulta de Entidades Qualificadas. OSCIPs. Disponível em: http://www.mj.gov.br. Acesso em: 06 out. 2009. 


\section{TRIBUNAL DE CONTAS E TERCEIRO SETOR: FUNDAMENTOS DO CONTROLE}

\subsection{Os fundamentos do controle do terceiro setor pelos Tribunais de Contas}

Com a expansão da destinação de recursos públicos ao terceiro setor para prestação de serviços de interesse público, chama atenção o controle sobre ele exercido.

Para muitos autores ${ }^{307}$, o dever de controle e correspondente prestação de contas decorreriam do princípio, espírito ou regime republicano - embora este não receba definição doutrinária unânime.

Para Geraldo Ataliba, “o espírito que preside todo tipo de atividade controladora é rigorosamente o mesmo e não se modifica essencialmente: o espírito republicano" ${ }^{\text {308 }}$, pois o "regime republicano é o regime da responsabilidade", no qual todos os agentes públicos respondem por seus atos, como contrapartida aos poderes que são investidos. ${ }^{309}$

Carlos Ayres Britto observa:

Tão elevado prestígio conferido ao controle externo e a quem dele mais se ocupa, funcionalmente, é reflexo direto do princípio republicano. Pois, numa República, impõe-se responsabilidade jurídica pessoal a todo aquele que tenha por competência (e consequente dever) cuidar de tudo que é de todos, assim do prisma da decisão como do prisma da gestão. E tal responsabilidade implica o compromisso da melhor decisão e da melhor administração possíveis. Donde a exposição de todos eles (os que decidem sobre a 'res publica' e os que a gerenciam) à comprovação do estrito cumprimento dos princípios constitucionais e preceitos legais que lhes sejam especificamente exigidos. A começar, naturalmente, pela prestação de contas das sobreditas gestões orçamentária, financeira, patrimonial, contábil e operacional.

É essa responsabilidade jurídica pessoal (verdadeiro elemento conceitual da República enquanto forma de governo) que demanda ou que exige, assim, todo um aparato orgânico-funcional de controle externo. E participando desse aparato como peça-chave, os Tribunais de Contas se assumem como órgãos impeditivos do desgoverno e da desadministração ${ }^{310}$.

307 Jaime Baleeiro Neto. As Organizações Sociais e os Tribunais de Contas. Dissertação (Mestrado em Direito Econômico) - Universidade Federal da Bahia, Salvador, 2002, 118p.

${ }^{308}$ Geraldo Ataliba. República e Constituição. 2. ed. São Paulo: Malheiros, 2007. p. 79.

${ }^{309}$ Ibid., p. 66.

${ }^{310}$ Cf. Carlos Ayres Britto. O Regime Constitucional dos Tribunais de Contas. Revista Diálogo Jurídico, Salvador, CAJ - Centro de Atualização Jurídica, v. I, $\mathrm{n}^{\mathrm{o}}$. 9, dezembro, 2001. Disponível em: http://www.direitopublico.com.br. Acesso em: 22 out. 2008. p. 11-12.

Segundo Benjamin Zymler, "decorre imediatamente do princípio fundamental da ordem constitucional brasileira que torna obrigatória a prestação de contas da Administração Pública (art. 34, VII, "d"), como decorrência da forma republicana de governo. Na República não há espaço para monarcas ou soberanos que se situem acima das leis [...], devendo aquele que lida com a res pública estar obrigado a comprovar a regularidade de sua gestão, por 
De acordo com o autor, tamanha "é a importância da prestação de contas, no espectro republicano, que o Texto Magno a positivou na sobranceira posição de princípio (art. 34, inciso VII, alínea $d)^{\text {"311. }}$.

Mas outros fundamentos vêm apresentados e, por si só ou em conjunto ao republicano, ensejam, além do dever de prestar contas pelas entidades privadas do terceiro setor, a atuação das Cortes de Contas sobre elas. O majoritário fundamento a respeito consiste na manutenção da natureza pública dos recursos que lhes são repassados a título de fomento ${ }^{312}$ - e não como contraprestação a fornecimento ou serviços prestados, típicos de contratos administrativos regidos pela Lei Federal n. 8.666/93 $3^{313}$.

Em regra, não cabe ao particular prestar contas aos Tribunais de Contas ou submeterse ao seu controle. Mesmo quando celebre contrato administrativo com o Poder Público, não deverá fazê-lo, pois os recursos públicos, nestes casos, são-lhe atribuídos como ressarcimento ou remuneração pelos serviços prestados, e não como fomento para o desenvolvimento de atividades de interesse social sem finalidade lucrativa, quando perdem a sua natureza de bens públicos. Destacam Afonso Gomes Aguiar e Márcio Paiva Aguiar que, na primeira situação “qualquer dano causado pelo particular ao setor público se resolverá no âmbito da ação civil,

meio da devida prestação de contas". Processo Administrativo no Tribunal de Contas. In: BRASIL, TCU, Prêmio Serzedello Corrêa 1996, 1997, p. 169.

311 Carlos Ayres Britto. O Regime Constitucional dos Tribunais de Contas. Revista Diálogo Jurídico, Salvador, CAJ - Centro de Atualização Jurídica, v. I, $\mathrm{n}^{\mathrm{o}}$. 9, dezembro, 2001. Disponível em: http://www.direitopublico.com.br. Acesso em: 22 de outubro de 2008. p. 11.

${ }^{312}$ No sentido de que os recursos públicos permanecem públicos mesmo após repassados ao terceiro setor - e por consequência evocam o controle das Cortes de Contas, citam-se:

- Gustavo Justino de Oliveira. Gestão privada de recursos públicos para fins públicos: o modelo das OSCIP. In: Gustavo Justino de Oliveira. Terceiro setor, Empresas e Estado: novas fronteiras entre o público e o privado. (Coord.) Belo Horizonte: Fórum, 2007. p. 231;

- Carlos Ari Sundfeld e Vera Scarpinella. Fundações Educacionais e Licitação. In: Leonardo Pantaleão (Coord.). Fundações Educacionais. São Paulo: Atlas, 2003. p. 256;

- Maria Tereza Fonseca Dias. O exercício do papel regulador do Tribunal de contas da União sobre as parcerias da Administração pública com as entidades do Terceiro setor na execução de políticas públicas. Anais do XVII Congresso Nacional do CONPEDI. Brasília -DF. P. 3456-3486 e

- Evandro Martins Guerra. Os controles externo e interno da Administração pública. 2. ed. rev. e ampl. Belo Horizonte: Fórum, 2005. p. 148.

O TCU, ao versar sobre as OSs, consignou: "O simples fato de receberem recursos financeiros da União em forma de dotação orçamentária, que por vezes representam parcela significativa de seus orçamentos, já é razão bastante para justificar sua submissão à jurisdição do TCU, seja no exame da respectiva prestação de contas, seja na observância das determinações deste Tribunal" (Acórdão n. 601/2007 - Primeira Câmara, p. 15).

${ }^{313}$ Na Decisão n. 592/1998, o TCU esposou entendimento no sentido de que as OSs, ao receberem recursos públicos, tornam-se deles gestoras e submetem-se aos controles financeiro e orçamentário por aquela Corte: "8.1. Firmar o entendimento de que as contas anuais das entidades qualificadas como organizações sociais, relativamente ao contrato de gestão, são submetidas a julgamento pelo Tribunal, nos termos do parágrafo único do art. 70 da Constituição Federal”. 
e não da tomada de contas especial [...], salvo nas hipóteses legais"314.

A legislação especifica e ratifica o entendimento no sentido da permanência pública dos recursos transferidos. A Lei Federal das OSs (art. 13) contém previsão expressa a respeito, inclusive quanto à reversão dos bens permitidos e dos valores entregues à utilização pela OS. Na mesma esteira, a Lei Federal das OSCIPs, trata os recursos repassados como "de origem pública", contendo a previsão de, na hipótese de desqualificação, destinar os recursos públicos recebidos durante a qualificação para outra OSCIP, preferencialmente de mesmo objeto social (art. $\left.4^{\circ}, \mathrm{V}\right)$, sempre vinculado a finalidade pública.

Ademais, segundo as citadas Leis, seus arts. $9^{\circ}$ e 12 determinam, respectivamente, que os Tribunais de Contas sejam informados da ocorrência de qualquer irregularidade ou ilegalidade na utilização de recursos ou bens públicos de origem pública.

Outro fundamento ao exercício de controle sobre o terceiro setor, até mesmo como desdobramento do primeiro, consiste na destinação pública em razão da qual os recursos são a ele cedidos, ou seja, a finalidade pública ${ }^{315}$ e não privada (remuneração, ressarcimento etc.) da transferência eventual dos recursos.

Alega-se também a natureza pública das atividades face ao interesse público visado, que por si só chamaria a competência dos Tribunais de Contas sobre as entidades em exame.

O vínculo formal ${ }^{316}$ com o Poder Público é adotado como outro fundamento ao controle pelos Tribunais de Contas das entidades do terceiro setor. São exemplos o reconhecimento estatal por meio de títulos, qualificações, certificações e a celebração de parcerias.

A depender do entendimento esposado, os efeitos das decisões do Tribunal de Contas podem implicar maior ou menor gravidade e responsabilidade. O vínculo formal, a natureza pública das atividades, o manejo de recursos públicos como fundamentos ao controle resultam em distintas extensões do seu exercício.

\footnotetext{
${ }^{314}$ Afonso Gomes Aguiar; Márcio Paiva de Aguiar. O Tribunal de Contas na ordem constitucional. 2. ed. Belo Horizonte: Fórum, 2008.

315 Para José Roberto Pimenta Oliveira “[...] mesmo não recebendo qualquer valor patrimonial derivado dos cofres públicos em razão daquela relação ( $v . g$. convênio sem repasse de bens e valores), a entidade particular será tutelada pela Lei de Improbidade [...]. Basta verificar a existência de relação jurídico-administrativa travada por determinada entidade para sobre ela incidir o regime sancionatório constitucional e legal na conduta de seus agentes. [...] em função da finalidade a ser perseguida.” (cit.), 2008. p.171.

${ }^{316}$ Para alguns autores, como Alexandre Ciconello, "a partir do momento em que o Estado reconhece um segmento de organizações da sociedade civil como de utilidade ou interesse público, consequentemente cria uma relação privilegiada com essas organizações, que se concretiza em uma maior facilidade de acesso a recursos públicos de forma direta ou indireta". O conceito legal de público no Terceiro setor. In. Eduardo Szazi. (org.). Terceiro setor: Temas Polêmicos 1. São Paulo: Peirópolis, 2004. p. 63.
} 


\subsection{Introdução às competências do Tribunal de Contas da União}

Convém tecer breves considerações sobre os Tribunais de Contas - em especial o da União, órgão controlador das transferências voluntárias de recursos públicos federais.

No Brasil, os Tribunais de Contas são órgãos autônomos, independentes e exercem o controle técnico ${ }^{317}$ no âmbito do controle externo. Não são órgãos integrantes da estrutura do Poder Legislativo ou auxiliares no sentido de inferioridade hierárquica ou subalternidade funcional.

A Constituição Federal, ao tratar da Organização dos Poderes no Título IV e no Capitulo I, acerca do Poder Legislativo, versa sobre a fiscalização contábil, financeira e orçamentária em seus arts. 70 a 75.

Extrai-se do art. $70 \mathrm{c} / \mathrm{c}$ o art. 71 que será exercida pelo Congresso Nacional, com auxílio do Tribunal de Contas da União, a fiscalização contábil, financeira, orçamentária, operacional e patrimonial de todas as entidades da administração direta e indireta quanto à legalidade, legitimidade, economicidade, aplicação de subvenções e renúncia de receitas. Outrossim, conforme disposto no parágrafo único do art. 70, qualquer pessoa física ou jurídica, pública ou privada, deverá prestar contas, caso utilize, arrecade, guarde, gerencie ou administre dinheiro, bens e valores públicos.

Os três Poderes, por sua vez, deverão manter, de forma integrada, sistema de controle interno a fim de comprovar a legalidade, avaliar os resultados da aplicação de recursos públicos por entidades de direito privado, e apoiar o controle externo no exercício de sua missão institucional (art. 74, incisos II e IV).

$\mathrm{O}$ art. $75^{318}$ prevê a aplicabilidade, no que couber, do acima exposto, à organização, composição e fiscalização dos Tribunais de Contas dos Estados, Distrito Federal e Municípios. Cada um detém competência para exercer fiscalização diferenciada, uma

\footnotetext{
${ }^{317}$ Benjamin Zymler. Direito Administrativo e Controle. Belo Horizonte: Fórum, 2005. p. 164.

Para Antonio Citadini, o desempenho dessas atividades tem por fim zelar pela observância do princípio da moralidade e eficiência administrativa, princípio republicano, dentre outros, por meio do controle da legalidade, legitimidade, efetividade, economicidade, razoabilidade, eficiência e eficácia da gestão, destacando-se, quase sempre, a análise dos resultados para o cidadão dos atos do gestor público. O Controle Externo da Administração Pública. São Paulo: Max Limonad, 1995, p. 107.

318 O foco principal do presente trabalho será o Tribunal de Contas da União, lembrando que por força deste artigo art. 75 da CF, as normas estudadas se aplicarão aos demais Tribunais de Contas, no que couber, o que poderá resultar em um alcance maior das considerações aqui esboçadas.
} 
complementar à outra, incidentes sobre a mesma operação ${ }^{319}$, pois em nome do princípio da economicidade e eficiência, seria inaceitável a sobreposição entre elas. Não há, todavia, disciplina constitucional acerca desta delimitação.

O tratamento do controle externo nas Constituições Estaduais, Lei Orgânica do TCU (LOTU) e regimentos internos dos demais Tribunais nem sempre coincide com o previsto na Constituição Federal. Daí as competências para a fiscalização do terceiro setor também não se apresentarem idênticas nestes órgãos.

Os citados preceitos constitucionais, ainda, têm recebido interpretações divergentes ${ }^{320}$, ampliando ou restringindo o âmbito das atribuições dos Tribunais de Contas em relação às entidades em apreço.

E, a depender da interpretação dos artigos da CF/88 aplicáveis e do entendimento esposado acerca das competências dos referidos Tribunais incidentes sobre o terceiro setor ${ }^{321}$, decorrem conseqüências práticas no tocante aos procedimentos adotados, a amplitude e aos efeitos de seu controle.

Sob o ponto de vista histórico, é marcante o esforço empreendido ao longo da evolução constitucional e legal brasileira no sentido de estabelecer mecanismos de controle dos recursos públicos ${ }^{322}$, como revelam a alteração da redação do parágrafo único do art. $70^{323}$

\footnotetext{
${ }^{319}$ Floriano Peixoto de Azevedo Marques Neto. Público e Privado no Setor de saúde. Revista de Direito Público da Economia - RDPE, Belo Horizonte, ano 3, n. 9, p. 105-154, jan./mar. 2005. p. 139.

${ }^{320}$ A análise dos regimentos internos das Cortes de Contas, de seus manuais, resoluções e decisões revela a divergência de tratamento do controle sobre as organizações do terceiro setor, em parte pelo tratamento legal estadual e municipal pertinente a estas entidades, distinto da disciplina federal em vários aspectos, inclusive quanto aos requisitos para recebimento de recursos públicos, qualificação, títulos ou certificações.

${ }^{321}$ Poucos autores analisam os incisos previstos no art. 71 da CF sob a ótica do controle pelos TCs sobre o terceiro setor. Andréa Nunes, ao tratar do controle e fiscalização daquele setor, a despeito de não desenvolver exame específico sobre cada um dos incisos que entende aplicáveis, enumera aqueles que a seu ver merecem destaque, quais sejam, II, IV, VI, VIII, IX, X e XI. Terceiro setor: controle e fiscalização. 2. ed. São Paulo: Método, 2006. p. 94-05.
}

${ }^{322}$ Nesta senda, Odete Medauar esclarece que: "Em tema de controle externo da Administração, a Constituição de 1988 ampliou as competências dos Tribunais de Contas (arts. 70 e 71, em especial)". (Constituição de 1988: catalisadora da evolução do Direito Administrativo? Revista do Advogado, ano XXVII, n. 99, p. 106. set. 2008).

Também Guilherme Henrique de La Rocque Almeida sinaliza que “Até 1988, a Corte de Contas Federal realizava o controle contábil, financeiro e orçamentário apenas sob a ótica da legalidade. Essa situação foi radicalmente alterada quando a Constituição Federal vigente, ampliando o escopo desse controle, conferiu ao TCU competência para fiscalizar aspectos operacionais e patrimoniais, inclusive no que concerne à legitimidade e à economicidade". Controle das Transferências Financeiras da União. [cit.], 2008a. p. 88.

323 "Na redação original desse parágrafo, o dever de prestar contas não era exigido das pessoas privadas. Essa mudança processada tem importância singular para a análise do controle das parcerias da Administração Pública com as entidades do terceiro setor pelo TCU”. Maria Tereza Fonseca Dias. O exercício do papel regulador do Tribunal de contas da União sobre as parcerias da Administração pública com as entidades do Terceiro setor na execução de políticas públicas. Anais do XVII Congresso Nacional do CONPEDI. Brasília DF. 2008b, p. 3456-3486. 
por meio da Emenda Constitucional n. 19/98 e a redação dos incisos II e IV do art. 71 da $\mathrm{CF} / 88$. Outrossim, o controle da economicidade e legitimidade foi introduzido na $\mathrm{CF} / 88$ como prova da ampliação dos aspectos de fiscalização de competência do TCU, que passou a controlar "a validade formal, a eficácia e o fundamento da execução orçamentária",324.

Assim, a tarefa a ser realizada consiste em examinar se há e quais são as competências constitucionais do TCU para fiscalizar as entidades que não são públicas, mas que desempenham atividades de interesse público sem finalidade lucrativa, com fomento por parte do Estado mediante a celebração de parcerias.

São poucos os estudiosos a oferecer um enquadramento teórico dessa recente realidade constitucional (controle de qualquer pessoa, física ou jurídica, privada ${ }^{325}$, que utilize, guarde, gerencie ou administre dinheiro, bens e valores públicos).

Há déficit e oscilações conceituais percebidas no âmbito da jurisprudência constitucional $^{326}$ e do TCU, motivo pelo qual este tem traçado diretrizes em decisões, manuais institucionais e resoluções ${ }^{327}$ de constitucionalidade discutível. A diversidade da legislação aplicável às entidades do terceiro setor também colabora para a utilização de parâmetros decisórios díspares, criando-se, assim, situação de insegurança jurídica, com repercussão na efetivação de controle pelos órgãos responsáveis.

\footnotetext{
${ }^{324}$ Ricardo Lobo Torres. A legitimidade democrática e o Tribunal de Contas. Cadernos de Direito Constitucional e Ciência Política. São Paulo. v.1. n.4. p.185-98. jul./set. 1993. p. 187.

${ }^{325}$ Destacamos que "entidade privada" aqui abordada não inclui as sociedades de economia mista, integrantes da administração pública indireta.

${ }^{326}$ O Supremo Tribunal Federal não se debruçou sobre a questão de competência dos Tribunais de Contas na medida liminar da ADIn n. 1.923-DF, por exemplo. Os acórdãos que examinam a competência dos Tribunais de Contas para fiscalizar pessoas jurídicas de natureza privada referem-se, na maioria dos casos, a entidades da administração indireta do Poder Público, como o Banco do Brasil. (MS 22801-DF, Relator Min. Menezes Direito. Julgamento em 17/12/2007, DJe 14/03/08. MS 23627-DF, Relator Carlos Velloso, DJ 16/06/2006) e as entidades do "Sistema S".

${ }^{327}$ O Tribunal de Contas da União já proferiu várias decisões a respeito, bem como editou o Manual "Convênios e Outros Repasses" (2008), enquanto o Tribunal de Contas do Estado de São Paulo editou o "Manual Básico Repasses Públicos ao Terceiro Setor” (2007).
} 
Analisar-se-ão, a seguir, os tipos de fiscalização previstos na $\mathrm{CF} / 88$ e seus aspectos, delimitando-os doutrinariamente, para depois verificar como se aplicam ao terceiro setor.

\subsection{Tipos de Fiscalização}

O caput do art. 70 da CF/88 estabelece a realização de fiscalização contábil, financeira, orçamentária, operacional e patrimonial da União e das entidades da Administração direta ou indireta, não permitindo, a princípio, sua incidência sobre o terceiro setor parceiro do Estado. No parágrafo único do citado preceito constitucional - reforçado, a nosso ver, pelo conteúdo dos incisos II e IV do art. 71, CF -, há menção, no entanto, ao dever de prestação de contas por entidades privadas quando gestoras de recursos públicos, podendo-se asseverar ter o constituinte incluído as entidades do terceiro setor no âmbito de incidência dos tipos de físcalização.

Os aspectos dos tipos de fiscalização são: legalidade, legitimidade, economicidade, exame de aplicação das subvenções e renúncia de receitas. Deverão, ainda, ser realizados por meio do controle externo (que inclui o TCU) e o interno de cada Poder.

Segundo Pedro Roberto Decomain, as Cortes de Contas devem se voltar também à preservação dos princípios constitucionais da Administração previstos no art. 37 da $\mathrm{CF}^{328} \mathrm{e}$ não só aos citados explicitamente no caput do art. 70 da CF/88.

A legislação específica do terceiro setor, por seu turno, menciona os princípios a serem por ele observados. Para elaboração do contrato de gestão, a Lei Federal das OSs previu a aplicação dos princípios da legalidade, da moralidade, da impessoalidade, da publicidade e da economicidade (art. $7^{\circ}$ ). A Lei Federal das OSCIPs, por sua vez, exigiu a previsão expressa nos estatutos destas de observância aos mesmos citados princípios, tendo acrescido somente o princípio da eficiência (art. $4^{\circ}$, inciso I).

O presente tópico restringe-se ao exame das competências do TCU mencionadas nos artigos 70, 71 e 72 da CF, deixando de tecer considerações específicas sobre os demais princípios e atribuições citados na doutrina e na legislação infraconstitucional. Justifica-se esta delimitação a fim de focar a análise nos atributos constitucionais do TCU em relação ao terceiro setor.

\footnotetext{
${ }^{328}$ Pedro Roberto Decomain. Tribunais de Contas no Brasil. São Paulo: Dialética, 2006. p. 200.
} 


\subsubsection{Fiscalização contábil}

O controle contábil refere-se à "fiscalização dos registros (balanços, por exemplo) que dispõe sobre o montante dos créditos e dotações, considerando os créditos e as dotações disponíveis" ${ }^{329}$.

O escopo desta fiscalização, segundo Márcia Semer, "é a apuração das operações, negócios ou transações realizadas pela Administração direta e indireta, bem como a verificação da correção das anotações contábeis referentes às diferentes operações, transações e negócios $" 330$.

Entendemos não haver obstáculo ao exame contábil pelo TCU de como os recursos públicos foram recebidos, guardados e despendidos pelas ONGs, a despeito de sobre elas não incidir o conteúdo do art. 83 da Lei n. 4.320/64. Afinal, se lhe cabe inspecionar, auditar e julgar as contas prestadas por estas entidades - conforme será objeto de oportuna explanação - para tanto, deverá fiscalizar contabilmente o tratamento dos recursos públicos por elas recebidos, e assim vêm procedendo o $\mathrm{TCU}^{331}$ e outras $\operatorname{Cortes}^{332}$.

\subsubsection{Fiscalização operacional}

Para Helio Saul Mileski, a fiscalização operacional ${ }^{333}$ "representa um estágio evolutivo no sistema de controle da atividade financeira do Estado" e

${ }^{329}$ Patrícia Cardoso Rodrigues de Souza. Controle da Administração Pública. In: Carlos Pinto Coelho Motta. (coord) et al. Curso prático de direito administrativo. 2. ed. Belo Horizonte: Del Rey. 2004. p. 567.

${ }^{330}$ Márcia Maria Barreto Fernandes Semer. Competências constitucionais do Tribunal de Contas. Dissertação (Mestrado em Direito Administrativo) Faculdade de Direito, Universidade de São Paulo, São Paulo, 2000. p. 23-24.

${ }^{331}$ BRASIL. TCU, Acórdão no 2261, 13 de dezembro de 2005. Plenário, p. 5.

${ }^{332}$ Neste sentido, as Instruções Normativas n. 01 e 02 de 2008 do TCE-SP expressamente preveem que, em até 90 dias do encerramento do exercício financeiro, as entidades da administração direta e indireta que tenham celebrado parcerias com o terceiro setor deverão a ele encaminhar "outras demonstrações contábeis e financeiras" da entidade privada sem fins lucrativos.

333 A fiscalização operacional refere-se à "obediência aos meios legais de liberação de verbas ou de sua arrecadação", quando deve haver "rigoroso controle sobre as formas de procedimento da despesa, atendendose ao atingimento dos objetivos traçados". Regis Fernandes Oliveira. Curso de Direito Financeiro. 2. Ed. São Paulo: Revista dos Tribunais, 2008. p. 390.

Tem, assim, por objetivo "verificar a efetividade e a economicidade das atividades e processos administrativos, bem como de programas de governo". Francisco Eduardo Carrilho Chaves. Controle externo da gestão pública: a fiscalização pelo legislativo e pelos Tribunais de contas: teoria e jurisprudência. Rio de Janeiro: Impetus, 2007. p. 60. 
(...) visa avaliar o grau de cumprimento dos objetivos e metas previstos na lei orçamentária; determinar a eficiência (máximo de rendimentos sem desperdício de gastos e tempo), a eficácia (realização das metas programadas) e a economicidade (operação ao menor custo possível) dos atos de gestão praticados; avaliar a eficácia do controle na administração dos recursos humanos, materiais e financeiros, identificando as áreas críticas na organização e funcionamento da Administração, com vistas a formular recomendações que possibilitem superar as observações mais significativas. ${ }^{334}$

Neste sentido, para Márcia Semer, se por um lado a fiscalização operacional significa a “apuração do 'modus operandi' a Administração na realização de suas atividades que envolvem valores, dinheiros e bens públicos", "de outra sorte, envolve a avaliação do desempenho do órgão fiscalizado", que deve vir "acompanhado de sugestões para o necessário aprimoramento". Representa "forma de controle sofisticada, que objetiva a melhoria do funcionamento do ente fiscalizado nos aspectos de redução dos custos (economia), eficácia de suas ações e eficiência de seus resultados"335.

Relativo às entidades do terceiro setor receptoras de recursos públicos, poderão ser fiscalizadas em termos operacionais pelos Tribunais de Contas para se averiguar a eficiência, eficácia e economicidade da sua gestão dos recursos públicos, com ressalvas, nos termos acima expostos ${ }^{336}$.

A título de exemplo, tal parece ser a intenção da Lei das OSs, na qual se previu o exame de relatórios gerenciais e de atividades da entidade, a fiscalização do cumprimento das diretrizes e metas definidas, critérios objetivos de avaliação de desempenho, com indicadores de qualidade e produtividade ( $\operatorname{art} .4^{\circ}$, incisos IX, X; $7^{\circ}$ e $8^{\circ}$ ). Também a Lei das OSCIPs exige a apresentação de relatório acerca da execução do termo de parceria, contendo o comparativo específico de metas propostas com os resultados alcançados e a prestação de contas dos gastos e receitas efetivamente realizados (art. 10, $\S 2^{\circ}$, V e art. 11). Em ambos os casos, as exigências do legislador possibilitam a fiscalização operacional das entidades em comento.

\subsubsection{Fiscalização patrimonial}

Já a fiscalização patrimonial é “a verificação que se faz sobre os bens que integram o

\footnotetext{
${ }^{334}$ Helio Saul Mileski. O Controle da Gestão Pública. São Paulo: Revista dos Tribunais, 2003. p. 242.

${ }^{335}$ Márcia Maria Barreto Fernandes Semer. Competências constitucionais do Tribunal de Contas. (cit.), 2000. p. 25.

336 BRASIL. TCU, Acórdão no 1111, 11 de junho de 2008. Plenário. Disponível em: http://www.tcu.gov.br. Acesso em: 20 out. 2009.
} 
patrimônio público"337 e concerne "as alterações patrimoniais [que] devem ser fiscalizadas pelas autoridades públicas em benefício da preservação dos bens" que o integram ${ }^{338}$.

Nas palavras de Helio Saul Mileski, "possibilita um controle sobre a regularidade dos registros e a utilização dos bens públicos, com a finalidade de identificar os responsáveis pelo seu uso e guarda, no sentido de evitar que estes sejam utilizados de forma indevida ou descurados na sua proteção e conservação"339.

Para Márcia Semer, a fiscalização do TCU dá-se sobre todos os bens públicos, conforme constantes em registros da Administração (art. 94 e 95 da Lei n. 4.320/64) e:

\begin{abstract}
por consequência, sobre todos os atos relativos à utilização de bens públicos por particulares (autorização, permissão, cessão e concessão de uso, concessão de direito real de uso e enfiteuse), bem como sobre os atos que impliquem alienação de bens públicos (venda, doação, dação em pagamento, permuta, investidura, concessão de domínio e legitimação de posse) ${ }^{340}$.
\end{abstract}

Cabe a fiscalização patrimonial pelo TCU dos recursos e bens públicos repassados ao terceiro setor, por não perderem a sua natureza pública ${ }^{341}$.

No caso das OSs, o controle pelo TCU se dará pelo envio da relação dos bens móveis e imóveis sob permissão de uso para as finalidades do contrato de gestão, especificando forma e razão, inclusive as eventuais substituições dos respectivos bens. Referente aos termos de parceria, exige-se o envio de relação de eventuais bens imóveis adquiridos com recursos provenientes da sua celebração (art. 15 da LF nº 9.790/99).

Outrossim, há na Lei Federal das OSs inúmeros preceitos ${ }^{342}$ concernentes ao tratamento destinado a seu patrimônio - e consequentemente, objeto de controle pelo TCU. Não por outra razão, na Decisão n. 592/1998, este asseverou que, ao receberem recursos públicos, as OSs tornam-se deles gestoras e submetem-se ao seu controle patrimonial.

\footnotetext{
${ }^{337}$ Márcia Maria Barreto Fernandes Semer. Competências constitucionais do Tribunal de Contas. (cit.), 2000. p. 26.

${ }^{338}$ Regis Fernandes Oliveira. Curso de Direito Financeiro. (cit.), 2008. p. 390.

${ }^{339}$ Helio Saul Mileski. O controle da gestão pública. (cit.), 2003. p. 243.

${ }^{340}$ Márcia Maria Barreto Fernandes Semer. Competências constitucionais do Tribunal de Contas. (cit.), 2000. p. 26.

341 (BRASIL. TCE-SP, Instrução Normativa $n^{\circ}$ 01/2008 - área estadual; BRASIL. TCE-SP, Instrução Normativa $\mathrm{n}^{\mathrm{o}}$ 02/2008 - área municipal.) Neste sentido, as Instruções Normativas n. 01 e 02 de 2008 do TCE-SP expressamente preveem que, em até 90 dias do encerramento do exercício financeiro, as entidades da administração direta e indireta que tenham celebrado parcerias com o terceiro setor deverão a ele encaminhar a publicação do Balanço Patrimonial da entidade parceira, dos exercícios encerrado e anterior, como forma de fiscalizar-lhe a movimentação de patrimônio - o que também consistirá em análise contábil.

${ }^{342}$ A título de exemplo, o art. $2^{\circ}$, inciso I, alínea $h$ (proibição de distribuição de bens e de patrimônio), $i$ (previsão de incorporação integral do patrimônio); art. 12, art. 13 e 16, $\S 2$ da Lei Federal das OSs. (BRASIL. PRESIDÊNCIA DA REPÚBLICA. CASA CIVIL, Lei $\mathrm{n}^{\circ}$ 9.637, de 15 de maio de 1998).
} 
No mesmo sentido, a Lei Federal das OSCIPs regulamentou o tratamento a ser dado a seu patrimônio, seja ou não de origem pública. Para este último, a Lei é expressa: as organizações deverão prestar contas de todos os recursos e bens de origem pública, conforme determina o parágrafo único do art. $70 \mathrm{da} \mathrm{CF}^{343}$.

A despeito disso, no Acórdão n. 601/2007, o TCU, ao diferenciar o regime das OSCIPs das OSs, entendeu que os bens públicos transferidos às primeiras deixam de ser públicos por passarem a transitar somente entre OSCIPs em caso de dissolução ou desqualificação - e não ao poder público, diversamente das OSs.

\subsubsection{Fiscalização financeira}

A fiscalização financeira diz respeito "ao ingresso e saída de dinheiro"344, para "verificar se as contas representam a efetiva situação financeira da Administração, envolvendo um controle sobre a arrecadação da receita e a realização da despesa, tendo em conta a legalidade e a regularidade das suas operações"345.

Consoante Helio Saul Mileski, a fiscalização financeira permite a avaliação da legalidade, legitimidade e economicidade, e, por meio dela, pode-se constatar "se foram adotados os meios adequados de se proceder à arrecadação da receita e se foram tomadas medida apropriadas para registrar com exatidão e salvaguarda todos os ativos financeiros, tais como disponibilidades, investimentos e demais valores imobilizados"346.

A fiscalização financeira será aplicável, com ressalvas, sobre as entidades do terceiro setor, pois a expressão arrecadação de receita não lhes diz respeito, nos mesmos moldes da Administração Pública.

\subsubsection{Fiscalização orçamentária}

Se pela fiscalização financeira verifica-se os efetivos dispêndios e ingressos nos cofres públicos, pela fiscalização orçamentária acompanha-se a fiel execução dos orçamentos, como o registro das despesas e receitas nas rubricas orçamentárias corretas e dentro dos limites

\footnotetext{
${ }^{343}$ Art. $4^{\circ}$, inciso VII, $d$. (Ibid)

${ }^{344}$ Regis Fernandes Oliveira. Curso de Direito Financeiro.(cit.), 2008. p. 390.

${ }^{345}$ Helio Saul Mileski. O Controle da Gestão Pública. (cit.), 2003. p. 241.

${ }^{346}$ Ibid., p. 241.
} 
impostos pelas leis orçamentárias ${ }^{347}$. Ela "incide sobre a correta aplicação da lei orçamentária", pois "as verbas apenas podem ter a destinação prevista no texto da lei especial aprovada"348.

Vez que as entidades do terceiro setor não se submetem ao regramento do orçamento público (Lei n. 4.320/64), entendemos ser-lhes inaplicável o exame do controle orçamentário.

No entanto, observamos que o controle orçamentário incidirá sobre os órgãos parceiros do terceiro setor. Neste sentido, as Instruções Normativas n. 01 e 02 de 2008 expressamente preveem o encaminhamento ao TCE-SP de cópia do instrumento com a proposta orçamentária e programa de investimentos, logo após a celebração do instrumento do contrato de gestão, pelas entidades da administração direta e indireta que o tenham celebrado com as OSs. Outrossim, até 90 dias após o encerramento do exercício financeiro, as citadas organizações deverão a ele encaminhar os balanços dos exercícios encerrado e anterior e demais demonstrações contábeis e financeiras, e respectiva publicação na imprensa oficial, seja da entidade pública gerenciada seja das OSs.

\subsection{Aspectos da fiscalização}

Ainda no caput do art. 70 da CF, previu-se a fiscalização quanto à "legalidade, legitimidade, economicidade", e quanto à “aplicação de subvenções e renúncia de receitas".

Hodiernamente, não se pode falar em controle de legalidade sem considerar a legitimidade a ela relativa. Tampouco se pode falar em legitimidade sem versar sobre o aspecto da economicidade. A despeito disso, por fins didáticos, serão observados a ordem e o rol dos aspectos da fiscalização constitucionalmente previstos no citado preceito.

Os aspectos da fiscalização serão examinados individualmente, primeiro para delimitá-los, segundo para verificar sua aplicabilidade sobre o terceiro setor.

\subsubsection{Legalidade}

Compreende-se o princípio da legalidade como um dever de respeito a toda a juridicidade $^{349}$ e não só a leis em sentido estrito.

\footnotetext{
${ }^{347}$ Francisco Eduardo Carrilho Chaves. Controle externo da gestão pública: a fiscalização pelo legislativo e pelos Tribunais de contas: teoria e jurisprudência. (cit.), 2007. p. 60.

${ }^{348}$ Regis Fernandes Oliveira. Curso de Direito Financeiro. (cit.), 2008. p. 390.

349 “A idéia de juridicidade administrativa traduz-se, assim, na vinculação da Administração Pública ao ordenamento jurídico como um todo, a partir do sistema de princípios e regras delineado na Constituição".
} 
Tradicionalmente, o princípio da legalidade envolve a Administração Pública e os entes explicitamente a ele vinculados.

A fiscalização da legalidade "dos atos de índole orçamentária e financeira é papel do Legislativo e dos Tribunais de Contas" ${ }^{\$ 50}$, e envolve o exame da adequação financeira ao orçamento e às leis; além da análise "formal das contas, seus aspectos da certeza, exatidão e correção de números e cálculos" ${ }^{\prime 31}$. Ademais, abrange a análise de constitucionalidade das leis $^{352}$ e dos atos administrativos, no sentido de preservar a ordem jurídica determinada constitucionalmente $^{353}$, tal como previsto na Súmula 347 do Supremo Tribunal Federal ${ }^{354}$.

Cabe questionar se o exame do dever de legalidade dos atos das entidades do terceiro setor pelo TCU seria o mesmo incidente sobre a administração direta e indireta. Ainda, quais princípios de direito público obrigariam as entidades em exame - e incidiria o controle de seu cumprimento, a derrogar parcialmente o regime privado.

A legalidade aqui indicada, na esteira de Maria João Estorninho, diferencia-se de seu conceito originário de legalidade estrita:

\begin{abstract}
[...] parece-me ser inevitável reconhecer a actual complexidade do princípio da legalidade, para o qual não é possível encontrar um sentido unitário ou unívoco. $\mathrm{Na}$ minha opinião, o conteúdo do princípio da legalidade ou da juridicidade, nomeadamente em relação à actividade de direito privado da Administração Pública, acaba afinal por apenas se 'descobrir' através das vinculações concretas que existem, e por intermédio das quais essa juridicidade se revela. ${ }^{355}$
\end{abstract}

Nesta esteira, as entidades privadas parceiras do Poder Público seriam vinculadas ao princípio da legalidade, mas somente para os casos de regulação específica de acordo com a legislação aplicável. ${ }^{356}$

Gustavo Binenbojm. Uma Teoria do Direito Administrativo: Direitos Fundamentais, Democracia e Constitucionalização. 2. Ed. São Paulo: Renovar, 2008. p. 143.

${ }^{350}$ Márcia Maria Barreto Fernandes Semer. Competências constitucionais do Tribunal de Contas. (cit.), 2000. p. 27.

${ }^{351}$ Ricardo Lobo Torres. A legitimidade democrática e o Tribunal de Contas. (cit.). jul./set. 1993. p. 189.

${ }^{352}$ BRASIL. TCE-SP, Legislação. Deliberação. Processo TCA - 29.268/026/05, 2005. Segundo a Súmula No 6 do TCE-SP: "compete ao Tribunal de Contas negar cumprimento às leis inconstitucionais".

${ }^{353}$ Helio Saul Mileski. O Controle da Gestão Pública. (cit.), 2003. p. 247.

${ }^{354}$ BRASIL. STF, Súmula 347, de 13 de dezembro de 1963. "O Tribunal de Contas, no exercício de suas atribuições, pode apreciar a constitucionalidade das leis e dos atos do poder público."

${ }^{355}$ Maria João Estorninho. A Fuga para o Direito Privado - Contributo para o estudo da actividade de direito privado da administração pública. (cit.),1996. p. 187.

${ }^{356}$ Márcia Pelegrini. Terceiro setor: gestão privada de recursos públicos. (cit.), jul./dez. 2008, p. 66.

Conforme já destacado, tem sido observada a tendência de aproximar a legalidade da administração pública e daquelas entidades, em especial quanto ao dever de licitar, previstos na IN n. 01/97 (BRASIL. SECRETARIA DO TESOURO NACIONAL, Instrução normativa $n^{\circ}$ 01, de 15 de janeiro de 1997) e alterações e o Decreto Federal $n$. 
O TCU, na Decisão n. 592/1998 - Plenário, ao deparar-se com a questão da sua jurisdição para julgar as contas das OSs, então recentemente criadas, a despeito de entender sobre elas incidir o princípio da legalidade, defendeu que o sistema jurídico passasse a priorizar o estabelecimento de normas de caráter principiológico e procedimental, para seu maior dinamismo. O controle da legalidade, a seu ver, cederia espaço ao controle teleológico ou finalístico. Nesta decisão, asseverou-se: o "padrão avaliador a ser utilizado pelo Controle Externo passa a ser o conteúdo e o fiel cumprimento do contrato de gestão, pois nele devem estar fixados adequadamente os objetivos e metas da entidade, bem como os critérios e parâmetros de avaliação quantitativa e qualitativa (indicadores de desempenho)".

O TCU diferencia, todavia, o tratamento dado a OSCIPs e OSs, implicando dizer que o controle da legalidade - a despeito de restrito aos princípios públicos - diverge conforme a qualificação da entidade do terceiro setor controlada. A justificativa para tal distinção seria o fato de o legislador ter aproximado as OSs de regime com maior densidade publicista e consequente menor liberdade operacional. Já as OSCIPs estariam vinculadas mais ao direito privado, minimamente derrogado por regras de direito público "no que toca à aplicação dos recursos públicos obtidos por meio do termo de parceria",357, possuindo "maior liberdade gerencial"358.

Ressalta-se, no entanto, não estar pacificada entre os Ministros do TCU, a questão da distinção entre as citadas entidades acerca da amplitude da legalidade sobre elas incidente ${ }^{359}$.

\subsubsection{Legitimidade}

Para Ricardo Lobo Torres, a fiscalização da legitimidade enseja o "controle de gestão,

5.504/05 (BRASIL. PRESIDÊNCIA DA REPÚBLICA. CASA CIVIL, Decreto nº 5.504, de 5 de agosto de 2005).

No mesmo sentido, o TCU já decidiu a respeito no Acórdão n. 601/2007 (BRASIL. TCU, Acórdão nº 601, de 20 de março de 2007. Primeira Câmara, Ministro Relator Aroldo Cedraz). Note-se que se configura "dever" imposto por instrumentos infralegais, quando a aplicação do "princípio da legalidade" é questionada, inclusive quanto a sua incidência sobre a Administração Pública por renomados autores como Gustavo Binenbojm. Uma Teoria do Direito Administrativo - Direitos Fundamentais, Democracia e Constitucionalização. 2. Ed. São Paulo: Renovar, 2008.

${ }^{357}$ BRASIL. TCU, Acórdão no 601, de 20 de março de 2007. Primeira Câmara.

${ }^{358}$ Ibid., p. 9.

${ }^{359}$ No Acórdão n. 1777/2005 (BRASIL. TCU, Acórdão nº 1777, de 09 de novembro de 2005. Plenário), a despeito de não ter prevalecido o voto do Ministro Revisor Ubiratan Aguiar, este se pronunciou no sentido de que também as OSCIPs, ao receber recursos públicos, assumem todos os deveres e obrigações de qualquer gestor público e, por isso, devem obedecer a legislação licitatória federal - e não a seu regulamento próprio, aplicando-se-lhe, inclusive, o Decreto Federal n. 5.504/2005. O Ministro Relator Marcos Vilaça e o Ministro Redator Walton Alencar Rodrigues, pelo contrário, concluíram explicitamente que tais exigências, além da IN n. 01/97 STN (1997), configuram-se imposição de excessivas amarras burocráticas ao termo de parceria e contrariam a própria finalidade da Lei da OSCIPs (BRASIL. PRESIDÊNCIA DA REPÚBLICA. CASA CIVIL, Lei no 9.790, de 23 de março de 1999), inviabilizando a autonomia e agilidade gerenciais. 
a análise de resultados e a apreciação da justiça e do custo/benefício, a ver se o cidadão realmente obtém a contrapartida do seu sacrifício econômico" ${ }^{\text {360 }}$.

Fiscaliza-se o atendimento das necessidades públicas. Verifica-se o cumprimento do bem público pretendido ${ }^{361}$, inclusive com controle de mérito dos atos ${ }^{362}$, entendido este como controle da legalidade e economicidade das decisões políticas ${ }^{363}$, e não a análise dos objetivos das decisões políticas.

Para Márcia Semer, o controle da legitimidade "não significa apenas a verificação da relação de adequação entre o ato administrativo praticado e a capacidade do agente de fazê-lo. Significa a verificação da relação de adequação entre o ato administrativo praticado e os valores e necessidades fundamentais da coletividade" ${ }^{, 364}$.

José Maurício Conti admite o controle da legitimidade quanto ao aspecto de mérito do ato objeto de fiscalização, pois assim, "determinado ato, ainda que realizado em consonância com as leis, pode não ser legítimo, por afrontar princípios jurídicos outros, como o da moralidade administrativa, tornando-se ilegítimo ou passível de impugnação por ocasião da fiscalização"365.

Marçal Justen Filho esposa entendimento contrário aos controles do mérito, da conveniência ou da discricionariedade, por ausência de expressa previsão constitucional neste sentido $^{366}$. Caberia, no entanto, o exame do desvio de finalidade ${ }^{367}$, abuso de poder ou se, diante das circunstâncias, a decisão adotada não fosse a mais adequada.

Parece-nos possível o exame pelo TCU da legitimidade dos atos das entidades do terceiro setor, quando envolverem recursos públicos, sem olvidar o enfoque finalístico de sua competência para tanto e as cautelas necessárias para evitar a ingerência indevida nos atos daquelas a ponto de as substituírem. Desde a Decisão n. 592/1998-Plenário, o TCU deixou consignado posicionamento neste sentido, ao versar acerca da sua jurisdição sobre as OSs, entendimento

\footnotetext{
${ }^{360}$ Ricardo Lobo Torres. A legitimidade democrática e o Tribunal de Contas. (cit.). jul./set. 1993. p. 192-193.

${ }^{361}$ Regis Fernandes Oliveira. Curso de Direito Financeiro. (cit.), 2008. p. 391.

${ }^{362}$ Márcia Maria Barreto Fernandes Semer. Competências constitucionais do Tribunal de Contas. (cit.), 2000. p. 29.

${ }^{363}$ Ricardo Lobo Torres. A legitimidade democrática e o Tribunal de Contas. (cit.) jul./set. 1993. p. 194.

${ }^{364}$ Para a autora, "a possibilidade de verificação da legitimidade dos atos administrativos orçamentários e financeiros constitui-se em abertura fundamental à alteração da qualidade de controle a cargo do Congresso e do Tribunal de Contas". Márcia Maria Barreto Fernandes Semer. Competências constitucionais do Tribunal de Contas (cit.), 2000. p. 29-30.

${ }^{365}$ José Maurício Conti. Direito Financeiro na Constituição de 1988. São Paulo: Oliveira Mendes, 1998. p. 5.

${ }^{366}$ Marçal Justen Filho. Curso de Direito Administrativo. 3. Ed. rev. atual. São Paulo: Saraiva, 2008. p. 900.

${ }^{367}$ BRASIL, TCU, Acórdão no 2261, 13 de dezembro de 2005. Plenário. No Acórdão n. 2261/2005 - Plenário, o TCU realizou auditoria em entidades privadas que haviam se conveniado com órgãos públicos em razão do desvio de finalidade, dentre outros, dos recursos públicos a elas atribuídos.
} 
passível de ser estendido às demais entidades do terceiro setor parceiras do Estado ${ }^{368}$.

De todo modo, o TCU deverá levar em conta o teor dos instrumentos de parceria para analisar o mérito dos atos do terceiro setor.

\subsubsection{Economicidade}

A fiscalização da economicidade pelos Tribunais de Contas consiste no "controle da eficiência da Administração Pública, resultante da análise da utilização da capacidade de potencializar a receita frente às despesas e da capacidade de reduzir o custeio para adaptá-lo à arrecadação",369.

Exige análise abrangente e pode envolver processo de prestação de contas ou auditoria, sugestões e orientações acerca da eficiência ou ineficiência dos atos controlados como resultado de auditorias operacionais ou de gestão, num processo de colaboração das Cortes de Contas no aprimoramento da Administração ${ }^{370}$.

Com a promulgação da Emenda Constitucional n. 19/1998, a eficiência ${ }^{371}$ alcançou status de norma constitucional, cabendo aos Tribunais "verificar se as entidades sujeitas ao seu poder controlador atuam de forma eficiente" ${ }^{\text {372 }}$.

Ressalta James Giacomoni que o "teste da eficiência na avaliação das ações governamentais busca considerar os resultados obtidos em face dos recursos disponíveis. Busca-se representar as realizações em índices e indicadores, para possibilitar comparação

\footnotetext{
${ }^{368}$ De se ressaltar que no Anteprojeto de Lei Orgânica da Administração Pública, (BRASIL. COMISSÃO DE JURISTAS, Anteprojeto de Lei Orgânica da Administração Pública Federal e Entes de Colaboração, 2009) como princípio fundamental decorrente da separação de Poderes, entendeu-se pela impossibilidade de os órgãos de controle externo - notadamente o Tribunal de Contas - interferirem na gestão dos órgãos ou entidades submetidos ao seu controle. Tampouco poderão praticar atos que impliquem ingerência no exercício de suas competências ou na definição de políticas públicas. Segundo consta, o controle externo será amplo, todavia, compreendendo a aplicação de recursos ou bens públicos, os resultados e a legalidade. No que respeita a entidades do terceiro setor, de acordo com o referido Anteprojeto, os órgãos de controle limitar-seão à verificação da regularidade do contrato e de seus resultados, não sendo admitido controle ou interferência na gestão da entidade não estatal.

${ }^{369}$ Márcia Maria Barreto Fernandes Semer. Competências constitucionais do Tribunal de Contas. (cit.), 2000. p. 30.

${ }^{370}$ Ibid., p. 31.

${ }^{371}$ Emerson Gabardo destaca: “Cabe rememorar que o art. 70 da Constituição Federal estabelecia em seu caput, mesmo antes da Reforma Administrativa, que compete ao Congresso Nacional o controle de eficiência específico para a gestão administrativo-financeira, em que pese não se utilize do termo, pois há referência expressa a um aspecto da eficiência: a economicidade. A expressão 'economicidade' é justificável, haja vista que o artigo tem referência direta com a atividade contábil, orçamentária e patrimonial (além da operacional)." Princípio Constitucional da Eficiência Administrativa. São Paulo: Dialética, 2002. p. 112.
}

${ }^{372}$ Benjamin Zymler. Direito Administrativo e Controle. (cit.), 2005. p. 278. 
com parâmetros técnicos de desempenho e com padrões já alcançados anteriormente"373.

A doutrina reconhece a possibilidade do exame da economicidade dos atos das entidades privadas sem fins lucrativos objeto de fomento ${ }^{374}$. Segundo Emerson Gabardo:

A partir da conjugação dos dispositivos constitucionais que tratam da eficiência, e não somente do art. 37, que Paulo Modesto extrai seu amplo 'conceito' do princípio da eficiência, que consiste na exigência jurídica, imposta à administração pública e àqueles que the fazem as vezes ou simplesmente recebem recursos públicos vinculados de subvenção e fomento, de atuação idônea, economicamente satisfatória na realização das finalidades públicas que lhe foram confiadas por lei ou por ato ou contrato de direito público ${ }^{375}$. (g.n.).

\section{Para José Roberto Pimenta Oliveira:}

a utilização do 'terceiro setor', para desempenho de atividade administrativa, está constitucionalmente subordinada à observância in concreto do princípio da eficiência e da eficácia (art. 37-caput) e sua vertente de economicidade (art. 70caput), não podendo, em qualquer área, descaracterizar a responsabilidade estatal originária na realização dos cometimentos a cargo do Estado. Sem motivação cabal da economicidade do vínculo jurídico-administrativo, é ilegítima qualquer transferência de atribuições administrativas, passível de controle jurisdicional por ação popular (art. 5 - LXXIII) e ação civil pública (art. 129-III). ${ }^{376}$

Com a Decisão n. 592/1998 - Plenário, o TCU posicionou-se no sentido de poder fiscalizar os atos das OSs envolvendo recursos públicos acerca de sua economicidade, entendimento este extensível às demais entidades, a nosso ver.

Com foco na economicidade e eficiência, por recomendação do TCU, o governo federal criou o Portal dos Convênios ${ }^{377}$ e editou o Decreto n. 5.504/05, a serem objeto de

373 Para James Giacomoni, "Inúmeros indicadores são utilizados na avaliação de eficiência, especialmente aqueles que relacionam produtos finais com seus custos (produtividade/custo) e com os insumos principais (produtividade/mão-de-obra, por exemplo). A avaliação da qualidade do trabalho é outra questão ligada à eficiência que merece atenção, principalmente em certos tipos de realizações como obras públicas. Orçamento Público. 13. Ed. rev. ampl. São Paulo: Atlas, 2005. p. 309.

Parece-nos que o princípio da eficiência desempenha papel relevante, tendo ampliado, em conjunto com os demais princípios previstos na Constituição Federal vigente, a atividade dos Tribunais de Contas. Tanto que mais e mais têm regulamentado internamente como esta nova vertente de fiscalização deverá se dar na prática, sendo ilustrativo o portfólio de indicadores do serviço público do TCU. Disponível em www.tcu.gov.br. Acesso em 30/05/2008.

374 (PRESIDÊNCIA DA REPÚBLICA. CASA CIVIL, Lei no 4.320, de 17 de março de 1964). A Lei Federal n. 4.320/64, por seu art. 16, é expressa no sentido de que a suplementação de recursos, como a subvenção, somente será legítima ao se revelar mais econômica. O preceito é reiterado na legislação relativa à subvenção social.

${ }^{375}$ Emerson Gabardo. Princípio Constitucional da Eficiência Administrativa. (cit.), 2002. p. 112.

${ }^{376}$ José Roberto Pimenta de Oliveira. Improbidade Administrativa e Terceiro setor. (cit.), 2008. p.166.

${ }^{377}$ Foi criado o "Portal dos Convênios" (www.convenios.gov.br), inclusive em função de pleitos do Tribunal de Contas da União e o Decreto Federal n. 6.170/07, pelo qual se controlará os repasses de recursos públicos a entidades públicas e privadas. Serão cadastradas empresas fornecedoras e as entidades poderão delas adquirir 
análise oportuna.

Para Vanice Lírio Valle, entretanto, o controle sobre as entidades em comento não deveria prevalecer sob a lógica economicista do custo-benefício, própria da administração pública prestacional, mas sim de um Estado reflexivo, detentor de outros propósitos além daquele ${ }^{378}$.

\subsection{Renúncia de receita e aplicação de subvenções}

No caput do art. 70 previu-se o controle da renúncia de receita e a concessão de subvenções sociais e econômicas, segundo a legislação específica, incluindo as leis de diretrizes orçamentárias.

A renúncia de receitas não será objeto de exame neste trabalho, pois as entidades do terceiro setor não possuem competência para arrecadar, muito menos renunciar a receita (pública). Outrossim, a despeito de deterem imunidade ou receberem isenção, tal matéria não integra o objeto desta dissertação, focada nos casos decorrentes de repasse de recursos mediante parcerias.

A respeito da aplicação de subvenções, "o controle abrange desde a concessão da subvenção até a utilização ou emprego da verba recebida a este título", e fiscaliza-se "tanto o

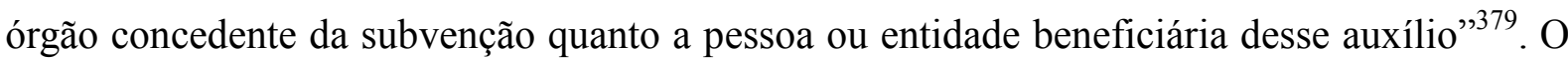
Regimento Interno do Tribunal de Contas (art. 255) foi claro neste sentido, tendo previsto: “a fiscalização da aplicação de recursos transferidos sob as modalidades de subvenção, auxílio e contribuição compreenderá as fases de concessão, utilização e prestação de contas e será realizada, no que couber, na forma estabelecida no art. $254^{\prime, 380}$.

bens e serviços, sendo que a contraprestação por estes será paga pelo governo federal diretamente a elas, sem intermédio das entidades em comento. A medida recebeu elogios da imprensa, tendo em vista, sobretudo, o controle dos recursos públicos repassados (Christiane Samarco; Lu Aiko Otta. Portal fiscalizará R\$ 35 bi em convênios. O Estado de São Paulo, São Paulo, 20 out. 2008).

${ }^{378}$ Vanice Lírio Valle. Terceiro setor e parcerias com a Administração Pública: desafios ao controle das OS e OSCIPs. Revista de Direito do Terceiro Setor, Belo Horizonte, ano 2, n. 4, p. 47-64, jul./dez. 2008. p. 53

${ }^{379}$ Márcia Maria Barreto Fernandes Semer. Competências constitucionais do Tribunal de Contas. (cit.), 2000. p. 31.

380 (BRASIL. TCM-SP, Instrução no 01, 1985). O Tribunal de Contas do Município de São Paulo regulou a matéria sob a ótica do controle a posteriori, quanto à aplicação dos recursos públicos, na Instrução Normativa n. 01/85, "a ser observada na comprovação e prestação de contas de auxílios ou subvenções concedidos a qualquer título, pelo Município, a entidades de direito público ou privado em geral e, em especial, a entidades de caráter assistencial ou que exerçam atividades de relevante interesse público". De acordo com a referida instrução, a "documentação comprobatória das despesas, bem como os livros da escrituração correspondente permanecerão na entidade à disposição do Tribunal de Contas, para os exames "in loco" julgados convenientes, os quais serão levados a efeito por servidores devidamente credenciados". Outrossim, segundo a citada Instrução, as “entidades que não obtiverem junto à Corte a aprovação de suas contas e respectiva quitação, 
A fiscalização da aplicação das subvenções recebidas pelas entidades do terceiro setor, parece-nos, coaduna-se perfeitamente ao conteúdo de sua legislação, pelo que poderá ser realizada pelos Tribunais de Contas ${ }^{381}$.

relativamente às importâncias recebidas no exercício anterior, ou que tiverem sua comprovação rejeitada, não poderão, sem prejuízo das demais cominações cabíveis, receber novos auxílios ou subvenções, fícando seus dirigentes sujeitos às penalidades legais".

${ }^{381}$ De acordo com Márcia Maria Barreto Fernandes Semer, "essa fiscalização pode ocorrer por meio da realização de inspeções ou auditorias, ou por ocasião da análise de processo de tomada ou prestação de contas". A autora esclarece que, "no caso da fiscalização realizada por inspeção ou auditoria, o acompanhamento da destinação dada aos recursos recebidos pela concessão de subvenção pode ocorrer concomitantemente à sua utilização. Já se o controle se dá apenas por ocasião da prestação de contas será a posteriori'. Competências constitucionais do Tribunal de Contas. (cit.), 2000. p. 32. 


\subsection{Competências constitucionais de controle incidente sobre o terceiro setor}

Tecidas as considerações gerais anteriormente expostas, passa-se ao exame das atribuições constitucionais do TCU que, ao menos em tese, incidiriam diretamente sobre as entidades em exame. Não serão analisados, portanto, os incisos I, V, VII e XI do art. 71 da CF.

Para fins deste trabalho, o controle direto ocorrerá quando houver fiscalização por parte do Tribunal de Contas sobre dada entidade do terceiro setor. Por sua vez, o controle indireto incidirá sobre o órgão público parceiro ${ }^{382}$ quando, por ordem ou recomendação do

\footnotetext{
382 Neste sentido parece ter caminhado o Tribunal de Contas do Estado de São Paulo, que abarcou em sua jurisdição todos os gestores de recursos públicos, mas, em termos práticos, previu nas suas Instruções 01 e 02 , editadas anualmente, o controle indireto das organizações não-governamentais, mediante exame das contas e dos documentos a elas relativos por intermédio do órgão parceiro. Constata-se que o tratamento dado pelo citado Tribunal de Contas às parcerias tem paralelo com aquele aplicado aos contratos administrativos firmados com empresas privadas - tal como a exigência de envio de cópia de instrumentos celebrados acima de certo valor, os documentos de habilitação da entidade, dentre outros:
}

“Artigo 14 - O Tribunal de Contas tem jurisdição própria e privativa sobre as pessoas e matérias sujeitas à sua competência, a qual abrange todos os responsáveis, bem como seus fiadores, herdeiros e sucessores, e qualquer pessoa física ou jurídica, de direito público ou de direito privado, que utilize, arrecade, guarde, gerencie ou administre bens e valores públicos ou pelos quais o Poder Público responda, ou que, em nome deste assuma obrigações de qualquer natureza. (...).

Artigo 15 - Estão sujeitos à jurisdição do Tribunal de Contas e só por decisão deste podem liberar-se de sua responsabilidade:

II - qualquer pessoa física ou jurídica de direito público ou de direito privado que houver arrecadado ou recebido depósito, auxílio, subvenção, e contribuição do Estado ou Município, ou tenha sob sua guarda e administração bens ou valores públicos;

IV - qualquer pessoa ou entidade mantida, ainda que parcialmente, pelos cofres públicos."

A Lei Orgânica do Tribunal de Contas do Município de São Paulo dispõe de maneira bem diversa:

"Art. $23 \mathrm{O}$ Tribunal tem jurisdição sobre pessoas e matérias sujeitas à sua competência, abrangendo todo aquele que arrecadar ou gerir dinheiro, valores e bens do Município ou pelos quais responda, bem como administradores das entidades da Administração Indireta e das Fundações instituídas pelo Município.

Art. 24 - Sob a jurisdição do Tribunal, ficam sujeitos, mediante exame e apreciação de suas contas e aferição da respectiva responsabilidade:

II - Todos os servidores públicos, qualquer pessoa ou entidade que seja ou não estipendiada ou subvencionada pelos cofres públicos municipais, e que derem causa a perda, subtração, extravio ou dano em valores, bens e materiais do Município".

No âmbito do TCU, sua Lei Orgânica previu de forma mais sintética:

"Art. $5^{\circ}$ A jurisdição do Tribunal abrange:

I - qualquer pessoa física, órgão ou entidade a que se refere o inciso I do art. $1^{\circ}$ desta lei, que utilize, arrecade, guarde, gerencie ou administre dinheiros, bens e valores públicos ou pelos quais a União responda, ou que, em nome desta assuma obrigações de natureza pecuniária;

II - aqueles que derem causa a perda, extravio ou outra irregularidade de que resulte dano ao erário;

VI - todos aqueles que lhe devam prestar contas ou cujos atos estejam sujeitos à sua fiscalização por expressa disposição de lei;

VII - os responsáveis pela aplicação de quaisquer recursos repassados pela União, mediante convênio, acordo, ajuste ou outros instrumentos congêneres, a Estado, ao Distrito Federal ou a Município; 
Tribunal, determinar-se a atuação daquele diretamente sobre a entidade ${ }^{383}$.

A ressalva parece-nos importante, pois a esfera de influência do TCU sobre o terceiro setor é muito maior que a simples fiscalização pessoal e in loco das entidades dele integrantes. A despeito de o foco essencial desta dissertação ser o controle direto, mostra-se relevante consignar o importante controle indireto hoje existente e, portanto, traçar breves linhas e considerações a respeito, se pertinente.

\subsubsection{Julgar prestação de contas}

\subsubsection{Considerações iniciais}

Por força do inciso II do art. 71 da CF/88, cabe ao TCU - e às demais Cortes de $\operatorname{Contas}^{384}$, julgar as contas dos administradores e demais responsáveis por dinheiros, bens e valores públicos da administração direta e indireta, incluídas as fundações e sociedades instituídas e mantidas pelo Poder Público Federal, e as contas daqueles que derem causa a perda, extravio ou outra irregularidade de que resulte prejuízo ao erário público ${ }^{385}$.

VIII - os sucessores dos administradores e responsáveis a que se refere este artigo, até o limite do valor do patrimônio transferido, nos termos do inciso XLV do art. $5^{\circ}$ da Constituição Federal".

${ }^{383}$ Neste sentido, conferir o Acórdão n. 1386/2009. Plenário. Relator: André Luis de Carvalho. Sessão de 24/06/2009. (Disponível em: http//:www.tcu.gov.br. Acesso em: 29/07/2009) e o Acórdão n. 1564/2009 Plenário. Min. Relator: Augusto Sherman Cavalcanti. DOU 17/07/09. (Disponível em: http//:www.tcu.gov.br. Acesso em: 29/07/2009). Neste último acórdão, o TCU teve por propósito da auditoria de conformidade realizada a pedido do Congresso Nacional verificar e analisar a estrutura e as ações internas voltadas para o controle dos recursos repassados por meio de transferências voluntárias, enquanto que, pelo primeiro acórdão, o TCU determinou que o órgão público parceiro passasse a agir de modo diverso em relação ao controle exercido sobre a entidade privada sem fins lucrativos com a qual celebrou termo de parceria.

${ }^{384}$ Nenhuma Constituição de Estado-membro poderá conter regra jurídica que conflite com a correspondente regra jurídica constitucional. Jorge Ulissses Jacoby Fernandes. Tribunais de Contas do Brasil: jurisdição e competência. 2. ed. Belo Horizonte: Fórum, 2005.2005b, p. 550.

${ }^{385}$ A Lei Orgânica do Município de São Paulo (2009) previu de forma diversa, dispondo explicitamente sobre outros entes jurisdicionados aos Tribunais de Contas:

“Art. 48. (...) II - apreciar, através de parecer, as contas dos administradores e demais responsáveis por dinheiro, bens e valores públicos, da administração direta, autarquias, empresas públicas e sociedades de economia mista, incluídas as fundações instituídas ou mantidas pelo Poder Público Municipal, e as contas daqueles que derem causa a perda, extravio ou outra irregularidade de que resulte prejuízo ao erário; $\S$ $2^{\circ}$ - Para efeito da apreciação prevista no inciso II, as entidades nele referidas deverão encaminhar ao Tribunal os seus balanços e demais demonstrativos até 5 (cinco) meses seguintes ao término do exercício financeiro."(g.n.).

No mesmo sentido, a Constituição do Estado de São Paulo: (1989):

“Art. 33. (...) II - julgar as contas dos administradores e demais responsáveis por dinheiros, bens e valores públicos da administração direta e autarquias, empresas públicas e sociedades de economia mista, incluídas as fundações instituídas ou mantidas pelo Poder Público estadual, e as contas daqueles que derem perda, extravio ou outra irregularidade de que resulte prejuízo ao erário;” (g.n.). 
Em que pese não se questionar o dever de as entidades do terceiro setor, receptoras de recursos públicos, prestarem contas a respeito de seu manuseio e aplicação ${ }^{386}$, há discussão doutrinária quanto à entidade competente para recebê-las e/ou julgá-las.

Em outras palavras, se por um lado, resta claro da leitura do parágrafo único do art. 70 da $\mathrm{CF} / 88^{387}$ a obrigação de prestar contas por parte daqueles que utilizem, guardem, gerenciem ou administrem dinheiros, bens e valores públicos, por outro, divergem a doutrina e os Tribunais de Contas acerca do órgão a quem as entidades privadas em exame, receptoras de recursos públicos financeiros, deverão fazê-lo: se aos órgãos públicos parceiros, do controle interno ou ao do controle externo. Ademais, a quem caberá julgar-lhes as contas, a depender do posicionamento adotado $^{388}$, pode não consistir na mesma pessoa que as recebeu para exame, sobretudo quando se argumenta no sentido da "nítida distinção entre o dever de prestar contas e

Inovando com a utilização da palavra "gestores", a Lei Complementar n. 709/1993 (Regimento Interno do TCE/SP) consignou: III - julgar, no âmbito do Estado e dos Municípios, as contas dos gestores e demais responsáveis por bens e valores públicos da administração direta e autarquias, empresas públicas e sociedades de economia mista, inclusive fundações instituídas ou mantidas pelo Poder Público, e as contas daqueles que derem causa a perda, extravio ou outra irregularidade de que resulte dano ao erário".

Também a Lei Orgânica do Tribunal de Contas da União (Lei 8.443/1992) pode ser interpretada no sentido da competência para julgamento da prestação de contas pelas entidades privadas gestoras de recursos públicos: “Art. $1^{\circ}$ Ao Tribunal de Contas da União, órgão de controle externo, compete, nos termos da Constituição Federal e na forma estabelecida nesta lei: I - julgar as contas dos administradores e demais responsáveis por dinheiros, bens e valores públicos das unidades dos poderes da União e das entidades da administração indireta, incluídas as fundações e sociedades instituídas e mantidas pelo poder público federal, e as contas daqueles que derem causa a perda, extravio ou outra irregularidade de que resulte dano ao erário; Art. $5^{\circ} \mathrm{A}$ jurisdição do Tribunal abrange: I - qualquer pessoa física, órgão ou entidade a que se refere o inciso I do art. $1^{\circ}$ desta lei, que utilize, arrecade, guarde, gerencie ou administre dinheiros, bens e valores públicos ou pelos quais a União responda, ou que, em nome desta assuma obrigações de natureza pecuniária; II - aqueles que derem causa a perda, extravio ou outra irregularidade de que resulte dano ao erário.”

${ }^{386}$ Entendemos, com Pinto Ferreira que "Toda pessoa física ou entidade que utilize, arrecade, guarde, gerencie ou administre dinheiros, bens e valores públicos ou pelos quais a União responda, ou que, em nome desta, assuma obrigações de natureza pecuniária, pelo texto constitucional, deverá prestar contas. A expressão usada pelo legislador constituinte é genérica e tem um sentido totalmente abrangente, pois compreende as pessoas físicas e jurídicas que: a) utilizem ou gastem dinheiros públicos; b) tenham responsabilidade na arrecadação dos dinheiros públicos, diretamente ou por delegação; d) guardem ou gerenciem dinheiros públicos; d) administrem dinheiros, bens ou valores públicos da responsabilidade da União; e) assumam obrigações de natureza pecuniária em nome da União.” Comentários à Constituição Brasileira. Arts. 54 a 91. 3. vol. São Paulo: Saraiva, 1992. p. 391.

Outrossim, concordamos com Ângela Cássia Costaldello: a "demonstração da melhor opção de gasto de dinheiro público deve ser exposta de modo inequívoco por aqueles particulares que recebem do erário público benefícios. A exigência, nesse sentido, não fere o princípio da legalidade, mas redunda na aplicação do princípio da juridicidade que o contém - e, sobretudo, protege os cofres públicos. A concretização do Estado Social e Democrático de Direito não se faz dispensando o particular de demonstrar que gastou adequadamente o dinheiro que o Estado, através de uma de suas manifestações materiais - o fomento -, lhe destinou, mas dele exigindo condutas que o todo - a coletividade - será beneficiado." Entidades privadas que recebem recursos públicos: necessidade de licitar. Boletim Informativos de Licitações e Contratos, Doutrina/Parecer, Curitiba, n. 82, dez. 2000. p. 140.

${ }^{387} \mathrm{Na}$ Constituição do Estado de São Paulo, (1989), há redação neste sentido no artigo 32, parágrafo único.

${ }^{388}$ Para Afonso Gomes Águia Aguiar e Márcio Paiva de Aguiar, caberá ao Tribunal de Contas receber e julgar a prestação de conta de entes privados, que tenham celebrado convênio com a Administração Pública. ( $O$ Tribunal de Contas na ordem constitucional. 2. ed. Belo Horizonte: Fórum, 2008. p. 61). 
o dever do Tribunal de Contas de julgar contas”389. Assim, apesar do dever de prestar contas, nem todos os entes deverão fazê-lo ao Tribunal de Contas ou terão suas contas por este julgadas.

Outrossim, os dispositivos constitucionais em comento (arts. 70 e 71), ao mesmo tempo em que parecem conferir aos Tribunais de Contas competência para fiscalizar a "gestão" de recursos públicos, independentemente de quem os “detenha" "390, parecem também não excluir o controle interno desenvolvido pela entidade pública parceira, repassadora ou controladora acerca da "aplicação de recursos públicos por entidade de direito privado" (art. 74) ${ }^{391}$.

A questão (a quem caberá receber e/ou julgar as contas prestadas pelas ONGs?), não é cristalina e pacífica. Há entendimento no sentido de atribuir ao controle interno a competência para controle preliminar, prévio ${ }^{392}$, preparatório ${ }^{393}$, deixando ao TCU a atuação posterior, quando da análise das contas prestadas ou tomadas ${ }^{394}$ ou "tomadas de contas especiais".

\footnotetext{
${ }^{389}$ Márcia Maria Barreto Fernandes Semer. Competências constitucionais do Tribunal de Contas. (cit.), 2000. p. 70.

${ }^{390}$ O Tribunal de Contas da União manifestou-se no seguinte sentido: “(...) qualquer que seja o modelo de organização, com ou sem contrato de gestão; qualquer que seja a natureza jurídica da entidade ou sociedade, com ou sem subvenções governamentais e dotações orçamentárias, pressupostos constitucionais (arts. 70 e 71 , II), estão sujeitas à jurisdição e fiscalização do TCU”. (Revista do Tribunal de Contas da União, Brasília, n. 50, p. 51-78, 1991). Outrossim, o citado Tribunal expressamente declarou: "Destaco que há vários processos em curso no âmbito desta Corte de Contas, nos quais busca-se apurar responsabilidades no que se refere à transferência/aplicação de recursos públicos federais referentes ao " $3^{\circ}$ setor", denotando os esforços empreendidos pelo TCU no desempenho de sua missão de zelar pela correta aplicação dos recursos públicos". (Acórdão n. 535/2008 - Plenário. Disponível em: <http://www.tcu.gov.br> $>$. Acesso em: 03 out. 2008).
}

${ }^{391}$ As Instruções n. 01 e 02 de 2008 do TCE-SP estabeleceram procedimentos de fiscalização de contrato de gestão, termo de parceria e convênios neste sentido entre o Tribunal de Contas e o controle do órgão parceiro.

392 Tendo em vista o modo como se encontra sistematizado o controle e descrevendo como sendo esta ordem na apreciação pelos órgãos competentes, a maioria dos autores discriminam a fase interna (pelo órgão administrativo) da fase externa (pelos Tribunais de Contas) do controle, como Jorge Ulisses Jacoby Fernandes (Tomada de Contas Especial: processos e procedimento nos Tribunais de Contas e na Administração Pública. 3.ed. Belo Horizonte: Fórum, 2005a. p. 531) e Ubiratan Aguiar (et al. Convênios e Tomadas de Contas Especial - Manual Prático. 2 ed. rev. ampl. Belo Horizonte: Fórum, 2007. p. 95).

393 "O controle interno financeiro-orçamentário tem por objetivo criar condições indispensáveis à eficácia do controle externo [...]”. Patrícia Cardoso Rodrigues de Souza. Controle da Administração Pública. In: Carlos Pinto Coelho Motta. (coord). Curso prático de direito administrativo. 2. ed. Belo Horizonte: Del Rey. 2004. p. 567.

${ }^{394}$ Neste sentido, o Enunciado n. 78 da Súmula de Jurisprudência do Tribunal de Contas da União (1976) é expresso: "[...] Não compete ao Tribunal de Contas da União julgar ou aprovar previamente contratos, convênios, acordos ou ajustes celebrados pela Administração Pública. Pode, todavia, o Tribunal, no exercício da auditoria financeira e orçamentária e com vistas ao julgamento das contas de responsáveis ou entidades sob sua jurisdição, tomar conhecimento dos respectivos termos, para, se verificar ilegalidade ou irregularidade, adotar providências no sentido de saná-las ou evitar sua reincidência." O Decreto-lei n. 200/67 já dispunha sobre a instrução de tomadas de contas antes do encaminhamento ao Tribunal de Contas (art. 81-84). A Lei Federal no 9.790/99 (Oscip), estabelece, em seu art. 11, que a "execução do objeto do Termo de Parceria será acompanhada e fiscalizada por órgão do Poder Público da área de atuação correspondente à atividade fomentada, e pelos Conselhos de Políticas Públicas das áreas correspondentes de atuação existentes, em cada nível de governo. $\S 1^{\circ}$ Os resultados atingidos com a execução do Termo de Parceria devem ser analisados por comissão de avaliação, composta de comum acordo entre o órgão parceiro e a Organização da Sociedade Civil de Interesse Público.§ $2^{\circ}$ A comissão encaminhará à autoridade competente relatório conclusivo sobre a avaliação procedida. [...]". 
Também existe a linha que atribui aos Tribunais de Contas a condição de destinatários ${ }^{395}$ e julgadores da prestação de contas das ONGs de modo direto, sem menção à interface do controle interno. Ainda se registra o entendimento no sentido de atuação conjunta do controle interno e externo ${ }^{396}$; ou de atuação do controle externo independentemente do controle interno, sobretudo quando de provocação em caso de comunicação, denúncia, representação ou realização de acompanhamento, monitoramento, inspeções e auditorias por iniciativa própria, que serão objeto de oportuna análise.

Não só acerca do momento do exercício se faz notar a disparidade de tratamento dos controles interno e externo. A doutrina, com base nos preceitos constitucionais, também faz distinção quanto ao foco da fiscalização: o dos Tribunais de Contas seria muito mais formal salvo a auditoria operacional (art. 71, IV, CF/88), enquanto o dos órgãos de controle interno, o resultado da gestão pública (art. 74, II, CF/88), podendo "avaliar o cumprimento de metas, a execução dos programas de governo, avaliar os resultados quanto a eficácia e eficiência"397.

A despeito de o controle externo muitas vezes prevalecer sobre o interno e de ambos manterem íntima conexão ${ }^{398}$ na fiscalização das entidades privadas sem fins lucrativos, os Tribunais de Contas podem atuar de modo independente à existência do controle interno, ou

\footnotetext{
395 “A própria Constituição da República veicula uma regra no exato sentido propugnado no parágrafo único do seu art. 70, no que diz respeito aos destinatários da obrigação constitucional de prestar contas aos Tribunais de Contas [...]", ressalta Gustavo Justino de Oliveira. Gestão privada de recursos públicos para fins públicos: o modelo das OSCIP. In Gustavo Justino de Oliveira. Terceiro setor, Empresas e Estado: Novas Fronteiras entre o Público e o Privado, (cit.), 2007b. p. 231.
}

Márcia Pelegrini também esposa entendimento similar, de que o parágrafo único do art. 70 legitima o controle das entidades em comento pelos Tribunais de Contas. Terceiro setor: gestão privada de recursos públicos. (cit.), jul./dez. 2008, p. 63.

Pedro Roberto Decomain sintetiza seu posicionamento da forma que segue: "O alcance desse preceito [art. 70, parágrafo único, CF] é extremamente amplo. [...] Mesmo entidades privadas que recebem recursos provenientes do erário devem deles prestar contas perante os Tribunais ou Conselhos de Contas. Ademais, as contas a serem prestadas por todo e qualquer gestor de recursos públicos serão apreciadas diretamente pelo Tribunal de Contas.” Tribunais de Contas no Brasil. (cit.), 2006. p. 82-83.

${ }^{396}$ Para Pedro Lenza: “A CF/88 consagra, dessa forma, um sistema harmônico, integrado e sistêmico de perfeita conveniência entre os controles internos de cada poder e o controle externo exercido pelo Legislativo, com o auxílio do Tribunal de Contas (art. 74, IV). Esse sistema de atuação conjunta é reforçado pela regra contida no art. $74, \S 1^{\circ}$, na medida em que os responsáveis pelo controle interno, ao tomarem conhecimento de qualquer irregularidade ou ilegalidade, dela deverão dar ciência ao TCU, sob pena de responsabilidade solidária." Direito Constitucional Esquematizado. 10 ed. Rev. Atual. Ampl. São Paulo: Método, 2006. p. 323.

397 Francisco Taveira Neto. A Evolução da Administração Pública e de seus Mecanismos de Controle na Constituição Federal. Revista Zênite de Direito Administrativo, Fórum, Belo Horizonte. p. 791-796., 2006, p. 794.

398 Para Rodrigo Pironti Aguirre de Castro, “O controle interno relaciona-se no sentido de cooperação com o controle externo. Pode-se dizer que ele é um braço do controle externo no seio da Administração Pública. [...]. Destaca-se, desta feita, o papel fundamental do controle interno de antever-se ao controle externo na atividade de controle e fiscalização da Administração Pública, no sentido de depurar ao máximo o controle, diminuindo desta maneira a demanda dos Tribunais de Contas que - na maioria dos casos - não controla um único ente e sim uma centena deles." Sistema de Controle Interno: uma perspectiva do modelo de gestão pública gerencial. Belo Horizonte: Fórum, 2007. p. 142-144. 
mesmo substituir o órgão parceiro se ausente o exercício de sua competência fiscalizatória ${ }^{399}$, mesmo que não estejam explícitas estas questões no corpo do texto constitucional e sedimentadas na doutrina.

Há, assim, possibilidade de controle pelo TCU de modo individual, simultâneo, substitutivo ou sucessivo, a propósito da fiscalização das entidades do terceiro setor, a depender do caso concreto, podendo se dar por iniciativa própria ou provocada, a ser pormenorizado adiante.

De todo modo, vale tecer considerações acerca da evolução da atividade do TCU no julgamento das contas das entidades em exame.

\subsubsection{Controvérsias sobre a competência para julgamento das contas}

Conforme verificado, não é pacífico o entendimento entre a doutrina e os Tribunais de Contas sobre a sedes materiae na $\mathrm{CF} / 88$ quanto à competência de apreciação e julgamento das contas das entidades do terceiro setor. Esta diversidade enseja reflexos na legislação infraconstitucional e nas interpretações dos preceitos constitucionais pertinentes, implicando

\footnotetext{
${ }^{399} \mathrm{O}$ controle interno não tem recebido elogios da doutrina, quer por sua inexistência quer por sua ineficácia, com consequências ao controle exercido pelos Tribunais de Contas, em razão da relação existente entre eles: tanto menor será a necessidade de controle externo quanto maior e mais eficiente o controle interno. A necessidade dessa fiscalização se faz patente diante dos inúmeros relatos, exemplificados pelo relatório do Acórdão TCU n. ${ }^{\circ 2.066 / 2006-P l e n a ́ r i o, ~ n o ~ q u a l ~ s e ~ d e s t a c o u: ~ " A g o r a, ~ c o n s t a t a-s e ~ q u e ~ t a m b e ́ m ~ a ~ f a s e ~ d e ~}$ acompanhamento e fiscalização da execução está sendo negligenciada pelos entes concedentes, aprofundando ainda mais a já pouca expectativa de controle por parte das entidades convenentes e impedindo a adoção de medidas tempestivas para corrigir a série de consequências nefastas que daí podem resultar, tais como o risco de descumprimento do objeto por inexecuções, execuções parciais ou imperfeitas, malversação e desperdício dos recursos transferidos".
}

Em outra oportunidade, restou consignado que "Tal situação é agravada, mais uma vez, pelo fato de os órgãos concedentes não disporem de estrutura suficiente. Situação, aliás, já há muito apontada por este Tribunal, conforme deixou assente o voto do Ministro-Relator do Acórdão TCU n. ${ }^{\circ}$ 788/2006-Plenário: O resultado do quadro descrito, como é de se inferir sem qualquer esforço extraordinário, é uma pluralidade de falhas, fraudes, desvios e outras irregularidades cometidas contra o erário, que seus autores já nem mais se preocupam em inovar os métodos ou sofisticar as práticas para levá-las a efeito. O que se vê é um acinte à sociedade, que custeia tais ações, e, que deveria ser beneficiária de seus produtos. Locupletam-se os grupos privilegiados, por um variado cardápio de irregularidades que é um verdadeiro ultraje à sociedade, à ordem institucional e aos órgãos de controle: transferência dos recursos da conta específica para outras contas; realização de saques em espécie, ou saques totais dos recursos sem correspondência com o cronograma físico-financeiro; utilização dos recursos em finalidade diversa da prevista e para despesas de manutenção do próprio convenente; remuneração indevida de pessoas e dirigentes (ONG); realização de despesas sem comprovação ou comprovadas mediante notas fiscais falsas, frias e clonadas; pagamentos por fornecimentos não realizados, simulações de fornecimentos, falsas medições e atestação de obras e serviços, superfaturamento quantitativo e qualitativo; compras sem licitação, direcionamento de licitação, simulação e fraude nos processos licitatórios; falta de aporte da contrapartida ou falsa comprovação dela; inexecução do objeto, execução parcial, imperfeita ou viciada, desvio dos recursos e inexistência do objeto pago; utilização do ajuste para promoção pessoal e para fins eleitoreiros etc.". Cf. BRASIL, TCU, Relatório e Pareceres Prévios sobre as Contas do Governo da República - Exercício 2006. Disponível em: <www.tcu.gov.br>. Acesso em: 12 de maio de 2009. 
em entendimento tanto pela incompetência como pela competência, e neste caso direta ou indireta, dos referidos Tribunais para receber e/ou julgar as prestações de contas das ONGs receptoras de recursos públicos. A expressão responsáveis contida no art. 71 , II da CF/88 desempenha importante função ao delimitar um ou outro posicionamento doutrinário.

a) Incompetência

Para os que entendem incabível a prestação de contas pelas entidades em exame ao TCU, por ser ele incompetente para tanto, o art. 71, inciso II da Constituição Federal teria obrigado somente as pessoas da Administração direta e indireta ${ }^{400}$, por seus administradores e responsáveis por dinheiros e valores públicos destas a fazê-lo, salvo no caso de prejuízo ao erário, dentre outras hipóteses ${ }^{401}$.

\footnotetext{
${ }^{400}$ Ao analisar o inciso II do art. 72, da CF em comento, é nos seguintes termos que Odete Medauar precisa seu entendimento proferido antes da EC n. 19/98: “(...) submeteu a esse controle a administração direta, indireta, fundações e sociedades mantidas pelo Poder Público e contas daqueles que derem causa de perda, extravio ou outra irregularidade de que resulte prejuízo do erário público. Nessa função, o Tribunal de Contas, com base em levantamentos contábeis, certificados de auditoria, pronunciamentos das autoridades administrativas e inspeções, aprecia a regularidade das contas dos ordenadores de despesa e todos os que tiverem recebido, administrado, arrecadado e despendido recursos públicos. Trata-se de verificação a posteriori, de modo geral." Controle da Administração Pública pelo Tribunal de Contas. Revista de Informação Legislativa, Brasília, a. 27, n. 108 , p. 120 , out./dez. 1990.
}

Também quanto ao assunto, José Afonso da Silva, consigna: "O âmbito de incidência do dispositivo [art. 70] é a Administração direta e indireta da União. [...]. A prestação de contas da administração é um princípio de ordem constitucional brasileira (art. 34, VII, “d”). '(...) qualquer pessoa física ou jurídica, pública ou privada, que utilize, arrecade, guarde, gerencie ou administre dinheiros, bens e valores públicos ou pelos quais a União responda, ou que, em nome desta, assuma obrigações de natureza pecuniária', está sujeita a prestação e tomada de contas pelo controle interno, em primeiro lugar, e pelo controle externo através do Tribunal de Contas, em segundo lugar, mas sem dependência daquele (art. 70, parágrafo único, com redação da EC 19/1998). Ao contrário do texto revogado da Constituição de 1969, isso agora se aplica tanto à Administração direta como às entidades da Administração indireta, na medida em que o caput do artigo as inclui no âmbito da fiscalização contábil, financeira, orçamentária, operacional e patrimonial prevista no artigo". Comentário contextual à Constituição. 5. ed. São Paulo: Malheiros, 2008. p. 463-465.

José Cretella Júnior, na mesma esteira, consigna: "Além de fiscalizar as contas dos administradores, o controle externo, a cargo do Congresso, exercido com o auxílio do Tribunal de Contas, incide sobre os demais responsáveis por dinheiros, bens e valores públicos de vários setores da Administração direta, indireta ou fundacional." Comentários à Constituição brasileira de 1988. Rio de Janeiro: Forense Universitária, 1997. p. 2800.

Há que se destacar que as citações são de obras anteriores a EC n. 19/98, que alterou a redação do parágrafo único do art. 70 da CF prevendo a obrigatoriedade de prestação de contas por entidades privadas gestoras de recursos públicos.

${ }^{401}$ Ao tecer comentários sobre o inciso II do art. 71, Celso Ribeiro Bastos e Ives Gandra Martins asseveram: "A parte final da dicção constitucional faz menção às contas de qualquer pessoa que derem causa a perda, extravio ou outra irregularidade de que resulte prejuízo para o erário público. À evidência, ao não distinguir quem seriam 'aqueles', o constituinte cuida de todos, servidores ou não, que tenham lesado o erário. [...] $\mathrm{O}$ inc. II pode ser resumido a que qualquer responsável da Administração direta ou indireta ou qualquer pessoa que tenha dado prejuízo ao Erário, deverá ter suas contas examinadas pelo Tribunal de Contas." Celso Ribeiro Bastos; Ives Gandra Martins. Comentários à Constituição do Brasil-promulgada em 5 de outubro de 1998. 4. 
Em outras palavras, as entidades do terceiro setor só teriam suas contas julgadas pelo TCU quando ensejassem prejuízo ao erário, pois a palavra responsáveis não abrangeria as entidades privadas gestoras de recursos públicos, posicionamento este esposado por Ives Gandra Martins e Celso Ribeiro Bastos ${ }^{402}$.

O TCU foi enfático a respeito: "não cabem prestações de contas sistemáticas ao Tribunal de Contas da União, de recursos repassados mediante convênio e instrumentos congêneres às entidades privadas sem fins lucrativos (ONGs), à exceção, até o momento, do contrato de gestão" 403 . No entanto, já para o ano de 2008, como se verificará adiante, nem mesmo a prestação de contas relativas ao contrato de gestão foi objeto de análise direta pelo TCU. A despeito de este entender que "responsável é um conceito amplo e difuso", está "relacionado a atribuições desempenhadas com o uso de recursos públicos em sentido lato" e, por força do art. 70, parágrafo único, art. 71, II, CF c/c art. 5º, I, art. $6^{\circ}$ e $7^{\circ}$, LOTCU, "essas pessoas incumbidas dessas atividades estão sujeitas a tomadas de contas

Ressalta-se que o TCU não exige a prestação de contas pelas OSs, diretamente, mas não exclui a sua jurisdição sobre elas ${ }^{404}$.

\section{b) Competência direta}

vol - tomo III. Art. 70 a 91. 3 ed. atual. São Paulo: Saraiva, 2002. p. 27-28.

${ }^{402}$ No sentido de que a expressão "e demais responsáveis" seria desnecessária por referir-se a administradores da Administração direta e indireta, Celso Ribeiro Bastos e Ives Gandra Martins assim se posicionam a respeito do inciso II do art. 71 da Constituição Federal: "De início, enuncia os demais gerenciadores de tais recursos, elencando pletora exemplificativa destes responsáveis da Administração direta e indireta. Cabe aqui a primeira observação de natureza diccional. Ao dizer 'os administradores e demais responsáveis', sendo os administradores também os responsáveis, à evidência, poderia o constituinte ter contraído o discurso para dizer 'os responsáveis"”. Celso Ribeiro Bastos; Ives Gandra Martins. Comentários à Constituição do Brasil (cit.), 2002. p. 25.

Rodrigo Pironti Aguirre de Castro, por sua vez, não incluiu ou excluiu explicitamente as organizações privadas sem fins lucrativos deste contexto. Sistema de Controle Interno: uma perspectiva do modelo de gestão pública gerencial. Belo Horizonte: Fórum, 2007. p. 138.

${ }^{403}$ BRASIL. TCU, Acórdão no 535, de 02 de abril de 2008, Plenário. Disponível em: www.tcu.gov.br. Acesso em: 20 out. 2009. p. 3.

404 “14. Nesse contexto, no caso das Organizações Sociais, o Tribunal, no uso do poder regulamentar que lhe confere o art. $3^{\circ}$ da Lei $n^{\circ} 8.443$, de 16 de julho de 1992, decidiu pela não-obrigatoriedade de prestação de contas, tendo em vista que os órgãos governamentais contratantes (supervisores) dessas entidades já devem, por disposição legal, supervisioná-las, acompanhá-las e avaliá-las. No entanto, os relatórios de gestão dos supervisores das OSs, deverão conter informações sobre o acompanhamento e a avaliação das entidades que celebram contrato de gestão, conforme disposto no item 19 da parte 2 do anexo II da DN/TCU 85/2007. 15. É importante ressaltar que o fato de o órgão ou entidade ter sido dispensado da apresentação de contas não significa que foi excluído da jurisdição do Tribunal, eis que a condição de jurisdicionado decorre de mandamento constitucional (arts. 70, parágrafo único, e 71)".

Cf. Acórdão TCU n. 4522/2008 - Ministro Relator Aroldo Cedraz. DOU 21/11/2008. Neste mesmo sentido, verificar o Acórdão TCU Plenário n. 613/2008, Ministro Relator Raimundo Correa, DOU 14/04/2008. 
Há defensores da competência direta do $\mathrm{TCU}^{405}$ - ou até mesmo do Poder Legislativo por força do art. 7 , parágrafo único da $\mathrm{CF} / 88^{406}$ - para receber as prestações de contas das ONGs gestoras de recursos públicos.

O fundamento para tal posicionamento - ao qual nos filiamos - atribui ao art. 71, inciso II, da CF/88 a interpretação de este inciso referir-se ao julgamento das "contas dos administradores (da Administração direta, indireta e fundacional) e dos demais responsáveis por dinheiros e valores públicos, bem como daqueles que derem causa a extravio, perda ou

${ }^{405}$ Lembra Benjamin Zymler que: “[...] não se pode olvidar a nova redação dada ao parágrafo único do art. 70 da Lei Maior, pela Emenda Constitucional n. 19/1998, que expressamente exigiu que prestem contas ao TCU todas as pessoas físicas e jurídicas, públicas ou privadas, que utilizem bens e dinheiros públicos". Direito Administrativo e Controle. Belo Horizonte: Fórum, 2005. p. 306.

Francisco Eduardo Carrilho Chaves, por sua vez, assevera: "O que caracteriza a obrigação de prestar contas ao TCU? Simplesmente a pessoa se enquadrar em uma das situações previstas no parágrafo único do art. 70: Utilizar, guardar, gerenciar ou administrar bens, dinheiros ou valores públicos, ou pelos quais a União responde; - Assumir em nome da União obrigações de natureza pecuniária." Controle externo da gestão pública: a fiscalização pelo legislativo e pelos Tribunais de contas: teoria e jurisprudência. (cit.), 2007. p. 63.

Com base em julgado do STF e sem distinguir se de origem pública ou não, Uadi Lammêgo Bulos, entende que “[...] o âmbito de físcalização dos Tribunais de Contas abrange quaisquer pessoas, jurídicas e físicas, públicas ou privadas, desde que os recursos recebidos por elas tenham origem estatal, pois a gerência de dinheiro público, ou a administração de bens e valores da comunidade, obriga à prestação de contas, nos parâmetros do art. 71, II (STF, RTJ, 160:448)”. (Constituição Federal Anotada. 7. ed. São Paulo: Saraiva, 2007. p. 892).

Vale transcrever ementa de acórdão do Supremo Tribunal Federal no qual analisa o dever de prestar contas de entidade privada receptora de recursos públicos:

"EMENTA: - Mandado de segurança. Tribunal de Contas da União.

2. Prestação de contas referente à aplicação de valores recebidos de entidades da administração indireta, destinados a Programa Assistencial de Servidores de Ministério, em período em que o impetrante era Presidente da Associação dos Servidores do Ministério.

3. O dever de prestar contas, no caso, não é da entidade, mas da pessoa física responsável por bens e valores públicos, seja ele agente público ou não.

4. Embora a entidade seja de direito privado, sujeita-se à fiscalização do Estado, pois recebe recursos de origem estatal, e seus dirigentes hão de prestar contas dos valores recebidos; quem gere dinheiro público ou administra bens ou interesses da comunidade deve contas ao órgão competente para a físcalização.

5. Hipótese de competência do Tribunal de Contas da União para julgar a matéria em causa, a teor do art. 71,

II, da Constituição, havendo apuração dos fatos em procedimentos de fiscalização, assegurada ao impetrante ampla defesa.

6. Regimento Interno do Tribunal de Contas da União, arts. $9^{\circ}, \S \S 1^{\circ}$ e $8^{\circ}, 119$ e 121 . Pauta Especial de julgamento publicada com inclusão do processo em referência.

7. Não cabe rediscutir fatos e provas, em mandado de segurança.

8. "Mandado de segurança indeferido." MS 21.644-DF. Min. Néri da Silveira. DJ 08/11/1996.

Note-se que a questão restou esclarecida no Anteprojeto de Lei do Estatuto do terceiro setor no seguinte sentido: "Art. 49. Somente as entidades do Terceiro Setor que recebam e apliquem recursos e bens de natureza pública, de qualquer espécie e a qualquer título, deverão prestar contas diretamente ao Tribunal de Contas competente."

${ }^{406}$ BRASIL. Tribunal de Justiça do Estado de São Paulo - TJSP. Apelação Civil com Revisão n. 857.329-5/4-00. Decisão unânime proferida em 10 fev. 2009: “(...) Nesse passo, declara-se afastada a ilegitimidade pronunciada pela origem e a legitimidade da Câmara Municipal de Andradina para exigir a exibição de documentos e de livros relativos à OSCIP Amada para a prestação de contas desta pessoa jurídica de direito privado, sustentada em parte por recursos públicos. De outra ponta, declara-se a obrigação da OSCIP Amada de proceder à prestação de contas em toda a amplitude necessária para o exaurimento da mesma à Câmara Municipal de Andradina.” 
contra irregularidade de que resulte prejuízo ao erário público" ${ }^{\natural 07}$.

Apontam-se outros fundamentos ao controle direto: (i) na ética e na moral, a despeito de se reconhecer a ausência de previsão constitucional para tanto ${ }^{408}$; (ii) no parágrafo único 409 e caput do art. 70 da $\mathrm{CF}^{410}$ ou, ainda, (iii) na combinação do art. 70, parágrafo único e inciso II do art. 71 da $\mathrm{CF}^{411}$. Em sendo assim, disposição em contrário pela legislação infraconstitucional seria inconstitucional ${ }^{412}$.

A favor do posicionamento do controle direto fundamentado na combinação do art. 70, parágrafo único com o inciso II do art. 71 da $\mathrm{CF} / 88$, poderia ser indicada a referência, no primeiro, do dever de prestar contas por quaisquer pessoas que utilizem, arrecadem, guardem,

${ }^{407}$ De acordo com Celso Antônio Bandeira de Mello. Curso de Direito administrativo. 25.ed. rev. atual. São Paulo: Malheiros, 2008. p. 929.

Pedro Lenza, é explícito no sentido de que "Também deverá prestar contas "qualquer pessoa física ou jurídica, pública ou privada, que utilize, arrecade, guarde, gerencie ou administre dinheiro, bens e valores públicos ou pelos quais a União responda, ou que, em nome desta, assuma obrigações de natureza pecuniária" (art. 70, parágrafo único, com a redação determinada pela EC n. 19/98)". Direito Constitucional Esquematizado. 10.ed. rev. atual. ampl. São Paulo: Método, 2006. p. 323.

${ }^{408}$ Paola Nery Ferrari e Regina Maria Macedo Nery Ferrari parecem entrar em contradição no seguinte trecho de sua obra, ora pelo dever de prestar contas, ora pela ausência legal deste dever: "[...] importante advertir que as Organizações Sociais ao receberem 'dinheiros, bens e valores públicos ou pelos quais a União responda, mediante Contrato de Gestão, têm o dever de prestar contas', conforme o parágrafo único do art. 70 da Constituição Federal. [...] As considerações aqui tecidas são fruto da análise eminentemente legal, como corolário da condição de pessoa jurídica privada das Organizações Sociais. Porém, importante lembrar que embora não haja determinação taxativa da obrigatoriedade de submissão das Organizações Sociais aos sistemas de controle previstos na Carta Constitucional, do ponto de vista ético, moral, tal escusa, por mera intelecção literal do texto normativo, não é louvável. [...] muito embora a Constituição Federal não obrigue textualmente as Organizações Sociais de observância dos controles por ela previstos, estes mesmo assim devem ser aplicados, guardadas as devidas peculiaridades, tendo em vista a concepção hierarquizada do ordenamento jurídico brasileiro." Controle das Organizações sociais. Belo Horizonte: Fórum, 2007. p. 133135 - grifos nossos.

409 Cf. Jayme Baleeiro Neto. As Organizações sociais e o controle dos Tribunais de Contas. Dissertação (Mestrado em Direito Econômico) - Universidade Federal da Bahia, Bahia, 2002. p. 109; e Vera Scarpinella; Carlos Ari Sundfeld. Fundações educacionais e licitação. In: Leonardo Pantaleão (Coord.); et al. Fundações educacionais. São Paulo: Atlas, 2003. p. 256.

${ }^{410}$ Neste sentido, extrai-se de obra de Juarez Freitas que: “d) Ambas as figuras do terceiro setor [organização social e organização da sociedade civil de interesse público] devem ser controladas pelos Tribunais de Contas (CF, art. 70) em relação a todos os recursos e bens de origem pública, além de precisarem conferir ampliada publicidade a seus atos de gestão, facilitando, ao máximo, o controle social”. O controle dos atos administrativos e os princípios fundamentais. 3. ed. rev. ampl. São Paulo: Malheiros, 2004. p. 289.

411 Esta é a opinião de Afonso Gomes Aguiar e Márcio Paiva de Aguiar: "O inciso II do art. 70 deve ser interpretado em harmonia com o parágrafo único do artigo 70, segundo o qual deverá prestar contas qualquer pessoa física ou jurídica, pública ou privada, que utilize, arrecade, guarde, gerencie ou administre dinheiro, bens e valores públicos ou pelos quais a União responda, ou que, em nome desta, assuma obrigações de natureza pecuniária. Logo, onde houver movimentação de bens ou recursos da União, haverá contas a serem julgadas pelo TCU e o processo de julgamento será o estabelecido na Lei Orgânica do Tribunal [...].” ( $O$ Tribunal de Contas na ordem constitucional. 2.ed. Belo Horizonte: Fórum, 2008. p. 42). O TCU, na mesma esteira, no que concerne às OSs, já adotou entendimento que o fundamento para submissão a sua jurisdição estaria no art. 70, parágrafo único e art. 71, inciso II da CF (Acórdão n. 601/2007 - Primeira Câmara, p. 16).

${ }^{412}$ Afonso Gomes Aguiar; Márcio Paiva de Aguiar. O Tribunal de Contas na ordem constitucional. 2.ed. Belo Horizonte: Fórum, 2008. p. 62. 
gerenciem ou administrem recursos públicos e, no segundo, a menção ao julgamento pelo TCU das contas dos "responsáveis" por recursos públicos, interpretados estes não como administradores públicos, mas aqueles privados previstos no parágrafo único do art. $70^{413}$.

Ressalta-se que a definição de "responsáveis" abrangendo as entidades em questão enseja implicações interpretativas em outros incisos do art. 71 - como o do IV, que remete ao inciso II -, ampliando ou restringindo-lhes a incidência.

Nesta esteira, caberia questionar se a nova redação do parágrafo único do art. 70 teria alterado o conteúdo do art. 71, inciso $\mathrm{II}^{414}$, adaptando as atribuições do TCU ao novo cenário de relação Estado-sociedade e se o fato de poder julgar as contas - ou independentemente disso - permite-lhe fiscalizar as entidades em apreço por meio de outros procedimentos, com ou sem a realização do controle interno. A conjugação daqueles preceitos já permitiu ao TCU incluir, pela Decisão n. 592/1998 - Plenário, as OSs no âmbito de sua jurisdição para fins de julgamento direto de suas contas - posicionamento este hoje alterado e adiante exposto.

Acerca do Tribunal de Contas incumbido de fiscalizar as entidades do terceiro setor, Francisco Eduardo Carrilho Chaves propõe a seguinte regra básica: a origem dos recursos informa a quem as contas devam ser prestadas. ${ }^{415}$ Sobre a questão, o Supremo Tribunal Federal foi categórico no sentido da inconstitucionalidade de lei que estabeleceu a descentralização da prestação de contas de recursos federais aos Tribunais de Contas de Estados e Municípios e ao TCU, quando a CF/88 foi clara no sentido da competência

413 "Por consequência, surgem importantíssimas indagações a respeito do tema, notadamente sobre os limites e as formas de atuação das Cortes de Contas em face da celebração dos múltiplos Termos de Parceria (TP)", como destaca Cláudia Fernanda de Oliveira Pereira. Os Tribunais de Contas e o Terceiro setor: aspectos polêmicos do controle. In: Gustavo Justino de Oliveira. (Coord.); et al. Terceiro setor, empresas e Estado: novas fronteiras entre o público e o privado. Belo Horizonte: Fórum, 2007. p. 317.

${ }^{414}$ A redação atual do preceito engloba pessoas físicas e jurídicas de natureza pública e privada, enquanto que anteriormente previa "qualquer pessoa física ou entidade pública que utilize, arrecade, guarde, gerencie ou administre recursos públicos ou pelos quais a União responda, ou que em nome desta assuma obrigações de natureza pecuniária”. Como havia celeuma quanto ao cabimento de exigir das entidades privadas da administração pública indireta a prestação de contas aos Tribunais de Contas, poder-se-ia questionar se a alteração do parágrafo único do art. 70 quis restringir-se a estas ou abarcar todas as pessoas privadas, independentemente de integrarem ou não a administração pública.

O questionamento cabe quando se verifica entendimentos como o de Lucas Rocha Furtado, "A tese da incompetência do TCU para fiscalizar empresas estatais foi - felizmente - revista pelo STF. No julgamento, ocorrido no ano de 2005, do MS n. 25.092/DF, o Plenário do STF definiu que 'o Tribunal de Contas da União, por força do disposto no art. 71 , II, da $\mathrm{CF}$, tem competência para proceder à tomada de contas especial de administradores e demais responsáveis por dinheiros, bens e valores públicos das entidades integrantes da administração indireta, não importando se prestadoras de serviços públicos ou exploradoras de atividade econômica', conforme artigo publicado no Informativo STF n. 408." Curso de Direito Administrativo (cit.), 2007. p. 1117.

415 Controle externo da gestão pública: a fiscalização pelo legislativo e pelos Tribunais de Contas: teoria e jurisprudência. Rio de Janeiro: Impetus, 2007. p. 63. 
exclusiva deste último para tanto ${ }^{416}$.

Defendemos o entendimento do controle direto do TCU sobre as ONGs receptoras de recursos públicos por melhor representar Estado garantidor do exercício da governança, da boa gestão dos recursos públicos e não dispensar os instrumentos disponíveis para tanto. Não se vislumbra, ademais, qualquer fundamento jurídico à interpretação restritiva da expressão "responsáveis" pela gestão de recursos públicos, a justificar a exclusão de entidades do terceiro setor de seu conceito, de modo a limitar a atuação dos Tribunais de Contas sobre elas.

c) Do posicionamento intermediário à competência indireta

Até 2008, o TCU aditou posicionamento intermediário em relação à prestação de contas das entidades em exame: somente as OSs deveriam fazê-lo diretamente, conforme a seguir exposto.

O TCU, ao versar sobre sua própria competência em face da referida entidade, na Decisão n. 592/1998 - Plenário, fundamentou-a na redação do inciso VI do art. 5 da Lei $8.443 / 92^{417} \mathrm{c} / \mathrm{c}$ art. 9 da Lei Federal das OSs. Interpretou-os no sentido de poder julgar as suas contas por força de expressa previsão legal, a despeito de o art. $8^{\circ}, \S 1^{\circ}$ da Lei das OSs indicar a prestação de contas ao órgão ou entidade supervisora. Segundo aquela decisão, este preceito não excluiria o controle pelo TCU.

Alguns autores não se opõem ao julgamento pelos Tribunais de Contas, diretamente, das contas das entidades qualificadas como $\mathrm{OSs}^{418}$ - não incluídas as demais entidades privadas sem fins lucrativos ${ }^{419}$.

\footnotetext{
${ }^{416}$ BRASIL. STF, Ação Direta de Inconstitucionalidade nº 1934, de 01 de setembro de 1999.

417 “Art. $5^{\circ}$ A jurisdição do Tribunal abrange: [...] VI - todos aqueles que lhe devam prestar contas ou cujos atos estejam sujeitos à sua fiscalização por expressa disposição de lei;”.

418 “....] desde a Decisão Plenária n. 592/98, se firmou o entendimento de que as contas anuais das OS deverão ser submetidas ao julgamento deste Tribunal. Há autores que sustentam, inclusive, que as OS não estão dotadas da necessária autonomia administrativa, não podendo sequer ser consideradas ONGs, podendo ser confundidas como 'braços' da atividade estatal, considerando que há participação do Poder Público na administração e previsão de cessão de bens, de recursos e até de servidores.” (Cf. TCU. Decisão n. 1331/2008-Plenário. Disponível em: $<$ http://www.tcu.gov.br $>$. Acesso em: 03 out. 2008). Jorge Ulisses Jacoby Fernandes é enfático no sentido de que: "A competência do Tribunal de Contas sobre as organizações sociais é limitada à apreciação da prestação de contas, dever ao qual estão jungidas essas entidades, por força da Constituição, ainda que sejam inequivocamente não-estatais. Disse 'limitada' porque ao contrário do que ocorre com os entes estatais o tribunal não pode inspecioná-las ou auditá-las. Limita-se ao controle sobre o repassador do recurso e a obrigá-lo a tornar efetiva a ação de controle, podendo impor ou recomendar a alteração de cláusulas no contrato de gestão que melhor resguardem o interesse público. A fiscalização sobre as contas prestadas se faz pelo repassador, agente público." Tribunais de Contas do Brasil: jurisdição e competência. [cit.], 2005b. p. 510.

${ }^{419}$ De acordo com Luis Eduardo Patrone Regules: "Ademais, o controle relativo à regular execução dos convênios será exercido internamente, pela supervisão da própria Administração Pública e, externamente, o controle será
} 
Dentre os argumentos doutrinários e jurisprudenciais para tal posicionamento, está o da combinação do parágrafo único do art. 70 com o inciso II do art. 71, sob a alegação de as OSs assemelharem-se à administração indireta e, portanto, estarem nela contempladas ${ }^{420}$. Assim, permaneceria a interpretação de o inciso II do art. 70 referir-se às entidades da administração direta e indireta no que concerne ao julgamento de suas contas pelos citados Tribunais. Pela similaridade com as entidades da administração indireta ${ }^{421}$, as OSs também o deveriam ter ${ }^{422}$. Sob esta visão, de certa forma as OSs seriam uma extensão da administração pública, sobretudo as decorrentes de entidades públicas extintas.

Foi este o entendimento esposado pelo TCU na Decisão n. 931/1999 ${ }^{423}$ e Decisões

oriundo do Tribunal de Contas (art. 70, parágrafo único da Lei Maior) e do Ministério Público (art. 13 da Lei Federal 9.790/1999)." (Terceiro setor - Regime Jurídico das OSCIPs. São Paulo: Método, 2006. p. 132).

Também neste sentido, Sílvio Luís Ferreira da Rocha (Terceiro Setor [cit.], 2003. p. 131) e Diógenes Gasparini (Direito Administrativo, [cit.], 2002. p. 386), ao tratar das organizações sociais.

A Lei Federal n. 9.790/99 previu a obrigação de a OSCIP prestar contas ao término de cada exercício financeiro diretamente ao órgão estatal parceiro (art. 4, VII, $d \mathrm{c} / \mathrm{c}$ art. 10, V).

${ }^{420}$ Tal como visto no Capítulo I, a assertiva se dá porque, de fato, por exemplo, pela Legislação Federal, algumas organizações sociais poderão advir da extinção de entidades públicas (arts. 18 e 21 da Lei Federal n. 9.637/1998) - daí porque alguns entendem que se lhes deveria aplicar o arcabouço legal de direito público, mas outras poderão já nascer privadas, por movimento da sociedade civil e optarem por receber esta titulação, sem que se possa dar a elas tratamento semelhante a entes públicos.

${ }^{421}$ Conforme relata e critica Paulo Modesto, em Reforma administrativa e marco legal das organizações sociais no Brasil (cit.), ano 3, n. 30, abr. 1999.

${ }^{422} \mathrm{O}$ regime jurídico das organizações é duramente criticado pela doutrina, sobretudo quanto aos aspectos de direito público e privado por ele mesclados. Neste sentido, Juarez Freitas assim se manifesta: "Decididamente, como é irretorquível, as pessoas de direito privado em tela ficam manietadas, sem que se preserve a substância de Direito Público, tampouco se viabilizem operacionalmente as regras de direito privado. Não se ignora que, havendo recursos públicos, a regência maior sempre será de princípios publicistas. [...] Tal dominância de princípios publicistas, não das regras, parece existir também fora da estrutura formal da Administração, sem que regras burocratizantes devam asfixiar e descaracterizar o terceiro setor, nada acrescentando em matéria de controle ou de eficiência. [...] os bens públicos a serem alocados devem continuar públicos, havendo, em regra, tão-só, permissão de uso, não a doação dos mesmos (art.2, I ‘j’), ainda que admitida a permuta (art. 13). Constata-se, pois, um impressionante somatório de imperfeições.” O controle dos atos administrativos e os princípios fundamentais. 3.ed. rev. ampl. São Paulo: Malheiros, 2004. p. 284-285.

${ }^{423}$ Cláudia Fernanda de Oliveira Pereira, ao versar sobre o controle do Tribunal de Contas (da União) e o terceiro setor, aduz “(...) foi editada a Decisão n. 931/99, ocasião em que foi firmado o entendimento de que as Organizações Sociais prestariam contas diretamente ao TCU, enquanto as Organizações da Sociedade Civil de Interesse Público o fariam, anualmente, ao próprio Poder Público, isto é, ao órgão repassador de recursos, sob o fundamento de que sendo essas entidades não estatais, descaberia a prestação de contas sistemática ao TCU. Este, por seu turno, ao analisar as contas anuais, teria a oportunidade de avaliar a celebração e a execução desses instrumentos. De qualquer modo, foi ressaltado que, no caso de irregularidades ou omissão na prestação de contas, a primeira forma de atuação direta do TCU é a instauração de Tomada de Contas Especial (TCE), típico procedimento administrativo que visa identificar os responsáveis e quantificar o débito. Ademais, considerando que, segundo a Lei Orgânica do TCU, no art. $5^{\circ}$, VII, a jurisdição daquele tribunal abrange os responsáveis pela aplicação de quaisquer recursos repassados pela União, mediante inclusive outros instrumentos congêneres aos acordos, ajustes e convênios, entendeu-se que os responsáveis particulares devem ser alcançados por essa previsão, mesmo pertencendo à esfera privada, já que os Termos de Parceria envolvem recursos públicos. Abriu-se, assim, o leque das TCE aos particulares, devendo ser interpretada de forma abrangente a jurisdição do TCU.” (Os Tribunais de Contas e o Terceiro setor: aspectos polêmicos do controle. In: Gustavo Justino de Oliveira. (Coord.); et al. Terceiro setor, empresas e Estado: novas fronteiras entre o 
Normativas, até a edição da Decisão Normativa n. 88/2007. Na esteira do posicionamento adotado em relação às OSCIPs, nesta última decisão, o TCU excluiu a exigibilidade da prestação de contas diretamente pelas OSs.

A Instrução Normativa TCU n. 47/2004 previa, em seu art. 2º inciso VIII, efetivamente, como unidades jurisdicionadas ao Tribunal, “as entidades públicas ou privadas que tenham firmado contrato de gestão com a administração pública federal e, em razão desse contrato, recebam recursos orçamentários da União", sem mencionar, contudo, as OSCIPs e o termo de parceria, por exemplo.

A Instrução Normativa TCU n. 054/2007, todavia, excluiu do art. $2^{\circ}$ aquela redação e substituiu-a pela obrigação das entidades submetidas a previsão legal de prestar contas ao TCU, sem mencionar as OSs, sendo que não há obrigação legal destas assim fazê-lo. Outrossim, ao definirem para 2008 as unidades jurisdicionadas cujos responsáveis deveriam apresentar contas ao TCU, as Decisões Normativas ns. 85/2007 e 88/2007, seguindo a mesma direção, não trataram diretamente daquelas entidades.

As alterações normativas expostas acerca da abrangência de competência direta do TCU sobre as OSs federais decorreram do Acórdão n. 1952/2007, o qual tratou do projeto de decisão normativa anual e definiu as unidades jurisdicionadas àquele. Tendo "em vista que os órgãos governamentais contratantes (supervisores) dessas entidades já devem, por disposição legal, supervisioná-las, acompanhá-las e avaliá-las”, decidiu-se pela não-obrigatoriedade de prestação de contas pelas OSs ao TCU - posicionamento reiterado no Acórdão n. 613/2008. Contudo, os relatórios de gestão dos supervisores dessas entidades, tanto públicas, quanto privadas, deveriam conter informações sobre o acompanhamento e a avaliação do contrato de gestão (item 19 da parte 2 do Anexo II do Anteprojeto).

No mesmo sentido, para o ano de 2009, a Decisão Normativa n. 093/2008, alterada pela Decisão Normativa n. 96/2009, indicou as unidades jurisdicionadas cujos responsáveis deveriam apresentar relatório de gestão referente ao exercício de 2008, especificando a forma,

público e o privado. Belo Horizonte: Fórum, 2007. p. 318). Na Decisão n. 931/1999-Plenário, do TCU, afirmou-se não caber às Organizações da Sociedade Civil de Interesse Público - OSCIP, a prestação de contas sistemática ao TCU. A Lei n. 8.443/1992 e normas inferiores não preveem a competência do TCU para recebimento direto de contas pelas entidades privadas sem fins lucrativos dos recursos a elas repassados mediante vínculo formal com a Administração Pública. "Por outro lado, ao analisar, para fins de julgamento, as contas anuais dos responsáveis, no âmbito estatal, pela celebração de termos de parceria, o Tribunal poderá avaliar a celebração e a execução desses instrumentos, nos termos do art. 71 da Constituição Federal e 1, 6, 7, 8, e 9 da Lei n. 8.443/1992", de acordo com Benjamin Zymler. (Direito Administrativo e Controle. [cit.], 2005. p. 308). Ademais, os fundamentos para este entendimento podem ser extraídos da própria legislação destas entidades privadas, por exemplo: Lei Federal n. 9.637/98, arts. $8^{\circ}-10$, Lei Federal n. 9.790/99, arts. 11 e 12 , Lei Federal n. 8.666/93, arts. 113 e 116. 
os prazos de sua apresentação e o seu conteúdo, sem mencionar explicitamente as OSs. Estabeleceu, ainda, aos órgãos ou entidades públicas fiscalizadoras dos contratos de gestão, o dever de apresentarem informações sobre o acompanhamento e avaliação relacionados à supervisão de entidades públicas e privadas e respectivos contratos de gestão.

Encerrou o TCU, desta forma, as discussões a respeito com a redação do art. $2^{\circ}, \S 2^{\circ}$ da Decisão Normativa n. 96/2009 ${ }^{424}$ :

$\S 2^{\circ}$ Os estados, o Distrito Federal, os municípios e as pessoas físicas ou entidades privadas, quando beneficiários de transferência voluntária de recursos federais sob qualquer forma, responderão perante o órgão ou entidade repassador pela boa e regular aplicação desses recursos, apresentando os documentos, informações e demonstrativos necessários à composição dos relatórios de gestão e dos processos de contas dos responsáveis por essas unidades jurisdicionadas.

Conclui-se, assim, o posicionamento intermediário em relação às OSs.

Relevante, no entanto, tecer considerações sobre o projeto de Instrução Normativa em substituição à IN TCU n. 47/2004, objeto do Acórdão n. 1842/2008-Plenário do TCU, estabelecendo normas de organização e apresentação de processos de tomada e prestação de contas. Trata-se de decisão ilustrativa do foco e dos fundamentos adotados pelo TCU para restringir sua competência constitucional acerca do julgamento de contas prestadas pelos responsáveis por bens, dinheiros e valores públicos.

No referido acórdão, por entender ser o conceito de responsável adotado pela $\mathrm{CF} / 88$ muito "amplo e irrestrito", o TCU propôs "redefinição conceitual de conta apresentada para fins de julgamento", distinguindo o processo de prestação de contas em sentido lato e em sentido estrito. Este último seria do responsável submetido a julgamento pelo TCU porque assim definido por esse Tribunal, com fundamento em seu poder regulamentar advindo da Lei Orgânica do Tribunal de Contas da União - LOTCU, já utilizado para dispensar a apresentação de contas pelas OSs e responsáveis pelas entidades de fiscalização de exercício profissional.

Como argumentos a esta distinção, alegou-se: (i) o volume de processos de contas julgados pelo TCU vez que a configuração do rol de responsáveis é exagerada, com ausência de qualidade no exame das contas daí decorrente; (ii) porque $90 \%$ das pessoas julgadas recebem quitação plena ou somente determinações, convertendo o TCU em guardião da segurança jurídica de gestores, e não dos recursos públicos, pois, em face de limitações da Corte, as contas não são examinadas adequadamente; (iii) o TCU deveria assumir seu papel regulamentador dos

\footnotetext{
${ }^{424}$ A Decisão Normativa n. 94 definiu para 2009 as unidades jurisdicionadas cujos responsáveis devem apresentar processos de contas relativas ao exercício de 2008, sob a forma, prazos e conteúdos dos demonstrativos que os comporão, nos termos dos artigos $4^{\circ}, 6^{\circ}, 13$ e 14 da Instrução Normativa TCU n n 57, de 27 ago. 2008.
} 
processos de prestação de contas, podendo, ao revés de dispensar a apresentação de contas para fins de julgamento ou continuar a receber "processos de contas" de inúmeros gestores, exigir apenas "relatório de gestão", se assim entendesse cabível; (iv) o TCU deveria atuar como agente indutor da accountability governamental, "ampliando e fortalecendo assim a rede de controle"; (v) com a diminuição dos impactos negativos do deferimento de processos e do sobrestamento de contas em razão de seu volume, o TCU poderia concentrar o uso de seus técnicos para a realização de fiscalizações condutoras, dentre outros, por meio da constituição de TCEs em caso de danos ao Erário provocados por aqueles responsáveis que não tenham sido julgados pelo TCU em processo de contas, tendo por foco a fiscalização concomitante, e não o controle $a$ posteriori; e, por fim, (vi) haveria aprimoramento na estrutura de responsabilização pela gestão e o estímulo à atuação coordenada da rede de controle.

$\mathrm{O}$ discurso do TCU exposto, salvo menção às OSs, e a redação idêntica ao art. $2, \S 2^{\circ}$ da Decisão Normativa n. 96/2009 nem mesmo tangenciaram a questão do julgamento de contas ou de relatório de gestão de outras ONGs gestoras de recursos públicos, acima transcrito, em que pese o volume de recursos a elas destinados não seja desprezível, tampouco os casos de malversações ao erário.

Foi explícito, todavia, em relação às OSCIPs, com entendimento de julgamento indireto das contas relativas aos termos de parceria com elas celebrados ${ }^{425}$, divergindo de posicionamento de outros Tribunais ${ }^{426}$.

Já o Regimento Interno do Tribunal de Contas do Estado de São Paulo expressamente prevê a competência das Câmaras para "o julgamento da prestação de contas dos recursos públicos destinados às Organizações Sociais" (art. 56, inciso $\mathrm{XV}^{427}$ ) e a competência do Conselheiro para as contas de outras entidades do terceiro setor: "julgar as prestações de contas de auxílios, subvenções, contribuições de origem estadual ou municipal concedidos às fundações mantidas ou instituídas pelo Poder Público municipal e estadual” e "julgar as prestações de contas de auxílios, subvenções, contribuições de origem estadual ou municipal concedidos às entidades particulares de caráter assistencial ou que exerçam atividades de relevante interesse público" ${ }^{, 428}$.

Há também autores defensores da atribuição dos Tribunais em comento para apreciar

\footnotetext{
${ }^{425}$ BRASIL. TCU. Decisão n. 931/1999 e Acórdão 1777/2005. Disponível em: http://www.tcu.gov.br. Acesso em: 06 out. 2009

${ }^{426}$ BRASIL. TCE-PE. Processo n. 0200880-4. Disponível em: http://www.tce.pe.gov.br. Acesso em: 06 out. 2009

${ }^{427}$ Disponível em: http://www.tce.sp.gov.br. Acesso em: 27 set. 2008.

${ }^{428}$ Incisos IV e V do art. 50 e art. 50-A, inciso II. Disponível em: http://www.tce.sp.gov.br. Acesso em: 27 set. 2008.
} 
e julgar as contas das entidades sub examine indiretamente ${ }^{429}$, após a avaliação e emissão de relatório conclusivo pelo órgão parceiro ou do controle interno deste. Assim, o julgamento previsto no art. 71, II da CF seria relativo exclusivamente aos casos de averiguação de irregularidade ou ilegalidade ${ }^{430}$ por meio de julgamento das contas do órgão parceiro ou da comunicação $^{431}$ ou pela prestação de informações pelos órgãos do sistema de controle interno $^{432}$, ou ainda pela omissão no dever de prestar contas ${ }^{433}$.

429 Nesta esteira, Andréa Nunes consigna: “A prestação de contas ao Tribunal de Contas é devida na forma do
inciso II acima transcrito, mas não pode ser apreciada por aquela Corte sem antes passar pelo Controle Interno do
órgão competente e pelo ordenador da despesa. A supressão de instâncias de controle pode ensejar a anulação de
atribuições e competências.” Terceiro setor: controle e fiscalização. (cit.), 2006. p. 96 .

Também esposa este entendimento Márcia Pelegrini. (Terceiro setor: gestão privada de recursos públicos. [cit.], jul./dez. 2008, p. 66). Neste sentido, a título de exemplo, a Resolução n. 0020/2005 do Tribunal de Contas do Estado de Pernambuco regulamentou a matéria da seguinte forma: "Art. 1. A Organização Social - OS e a Organização da Sociedade Civil de Interesse Público - OSCIP, ao celebrarem contratos de gestão ou termos de parceria, respectivamente, com a administração pública ficarão sujeitos a apresentar, anualmente, prestação de contas ao órgão descentralizador. [...].Art. 3. As contas relativas aos contratos de gestão ou termos de parceria celebrado com o Estado ou Município serão julgadas no bojo da prestação de contas do órgão ou entidade supervisora da OS ou do órgão parceiro da OSCIP encaminhada ao TCE-PE em até noventa dias após o encerramento de cada exercício financeiro [...]". Disponível em http://www.tce.pe.gov.br/resolucaovirtual/2005/r202005.htm. Acesso em 29 set. 2008.

${ }^{430}$ Cláudia Fernanda de Oliveira Pereira, consigna: "Quanto à fiscalização direta dos TP pelo TCU, foi dito que a mesma norma, ao aludir à já citada expressão 'instrumentos congêneres', permitiu o acompanhamento, podendo o Tribunal fiscalizar qualquer ato que resulte receita ou despesa, praticado por responsáveis sujeitos à sua jurisdição. Assim, só não competiria ao TCU julgar ou aprovar previamente mencionados termos, mas, poderia, no exercício da auditoria financeira e orçamentária, com vistas ao julgamento das contas dos responsáveis ou entidades sob sua jurisdição, deles tomar conhecimento, para, se verificar irregularidade e ilegalidade, adotar providências no sentido de saná-la. Desta forma, o TCU pode realizar fiscalizações diretas sobre os TP, por meio dos processos de contas. Em suma, a atuação direta do TCU sobre os Termos de Parceria poderá ocorrer em virtude de denúncias, Tomada de Contas Especial e/ou ações de acompanhamento e fiscalização". (Os Tribunais de Contas e o Terceiro setor: aspectos polêmicos do controle. In: Gustavo Justino de Oliveira. (Coord.); et al. Terceiro setor, empresas e Estado: novas fronteiras entre o público e o privado. Belo Horizonte: Fórum, 2007. p. 309-332). Não por outra razão, Benjamin Zymler entende que "[...] surge, assim, a primeira forma de atuação direta do TCU, pois o disposto nesse artigo [12 da Lei n. 9.790/1999] pode ensejar a instauração de uma tomada de contas especial, com base no que estatui o art. $8^{\circ}$ da Lei $\mathrm{n}$. 8.444/1992". (Direito Administrativo e Controle. [cit.], 2005. p. 309).

${ }^{431}$ Neste sentido, as Instruções n. 01 e 02 de 2008 do TCE-SP estabeleceram o dever de entidades do terceiro setor prestar contas ao órgão parceiro que, a depender do valor, remeterá àquele os documentos necessários para examinar as contas. Também nos casos em que o órgão parceiro não receba as contas, após adotados certos procedimentos, deverá comunicar o TCE-SP, que tomará as medidas pertinentes. A reiterar este entendimento, no item 6.1.2. do "Manual Básico - Repasses Públicos ao Terceiro Setor" consta que os Tribunais de Contas são competentes constitucionalmente para apreciar a prestação de contas de todos os recursos colocados a disposição de entidades beneficiárias. Para tanto, os órgãos concessores devem providenciar a remessa de cópias dos documentos ao TCESP nos prazos e de acordo com as citadas instruções.

${ }^{432}$ A este respeito, Pedro Humberto Teixeira Barreto entende: “[...] para o desenvolvimento de suas atividades de julgamento de contas dos administradores e demais responsáveis por dinheiro, bens e valores da União, o TCU utiliza informações fornecidas pelos órgãos do sistema de controle interno dos Poderes Executivo, Legislativo e Judiciário e do Ministério Público Federal. Tais informações são produzidas pelos mencionados órgãos em função do disposto no art. 74 da Constituição Federal [...]". O sistema Tribunais de Contas e instituições equivalentes: um estudo comparativo entre o modelo brasileiro e o da União Europeia. Rio de Janeiro: Renovar, 2004. p. 249.

433 “....] as pessoas que causam dano ao erário ou que, na condição de particular, gerenciam recursos públicos, 
Como se verifica, é ainda controvertido entre as Cortes de Contas o controle direto das OSs, por meio do exame e julgamento das contas por elas prestadas.

Também como posicionamento intermediário, é controversa a obrigatoriedade de prestação de contas pelas fundações mantidas, mas não instituídas pelo poder público.

Para Márcia Semer, de uma primeira leitura do inciso II do art. 71, conclui-se pela exclusão de dever neste sentido. No entanto, acerca do assunto, os Tribunais de Contas têm predominantemente se manifestado pela sua possibilidade ${ }^{434}$.

Conforme Gustavo Saad Diniz, para "se saber, criteriosamente, se uma fundação privada está sujeita ao controle do Tribunal de Contas, além do MP, é fundamental aferir se a entidade depende ou não dos recursos públicos, sob qualquer de suas formas". Para o autor, "se não houver o preenchimento desse requisito, não há que se falar em intervenção do TC", valendo o mesmo raciocínio para as fundações qualificadas como OS ou OSCIP ${ }^{435}$.

Todavia, em sentido contrário à interpretação extensiva do preceito legal ${ }^{436}$, Ives Gandra Martins assevera:

Tendo em vista que há fundações que não são mantidas pelo Poder Público, mas que são por ele auxiliadas, pergunta-se: no caso de fundações privadas, suas contas estariam também incluídas? E aquelas que se beneficiam de imunidades constitucionais, não estariam entre as beneficiadas pelo Estado? Suas contas estariam também sujeitas ao controle pelo Tribunal? Pelo discurso constitucional, não. Apenas aquelas instituídas pelo Poder Público diretamente por lei ou mediante autorização legislativa estariam sujeitas, à luz do art. 71, II.

d) Considerações finais

Em face de todo o exposto, o posicionamento pela ausência de atribuição dos Tribunais de Contas para julgamento das contas do terceiro setor poderá implicar em inconstitucionalidade de alguns tratamentos dados pela doutrina e referidos órgãos no sentido de sua competência.

Melhor parece, contudo, a interpretação da competência das Cortes de Contas para

como no caso de convênio, por exemplo, também têm o dever de prestar contas, mas não com a periodicidade anual, nascendo aí as chamadas contas especiais. Também são julgadas pelo Tribunal de Contas, em rito processual próprio e compatível com os princípios definidores da boa administração. Nessa hipótese, será preciso que fique caracterizada pelo menos uma das seguintes ocorrências: omissão no dever de prestar contas ou dano ao erário, decorrente de ato ilegal, ilegítimo ou antieconômico." Jorge Ulisses Jacoby Fernandes. Tribunais de Contas do Brasil: jurisdição e competência. [cit.], 2005b. p. 352.

${ }^{434}$ Márcia Maria Barreto Fernandes Semer. Competências constitucionais do Tribunal de Contas. (cit.), 2000. p. 75.

${ }^{435}$ Gustavo Saad Diniz. Direito das Fundações Privadas. 2. ed. Porto Alegre: Síntese, 2003. p. 270-271.

${ }^{436}$ Celso Ribeiro Bastos; Ives Gandra Martins. Comentários à Constituição do Brasil - promulgada em 5 de outubro de 1998. 4. vol - tomo III. Art. 70 a 91.3 ed. atual. São Paulo: Saraiva, 2002.p. 27. 
tanto, mediante apresentação de relatórios de gestão por elas elaborados. Dos preceitos constitucionais, esta atribuição é a mais evidente e, ainda assim, é negligenciada.

Nada obsta, entendemos, possam as contas ser objeto do controle interno de cada órgão parceiro, até por força do art. 74 da C/88, antes de seu exame pelo TCU, pois tratar-se-á de estratégia deste definir a respeito, sobretudo porque "necessário se faz acentuar a importância da atuação articulada e da interação dos órgãos de controle para que se apresentem resultados mais efetivos no controle da descentralização de recursos públicos"437.

A despeito de a legislação federal pertinente às OSs e OSCIPs não estabelecer o seu dever de prestar contas diretamente ao $\mathrm{TCU}$, a $\mathrm{CF} / 88$ não pode ser ignorada. Ademais, constata-se em ambos os casos a obrigatoriedade dos responsáveis pela sua fiscalização de dar ciência a este órgão ao tomarem conhecimento de qualquer irregularidade ou ilegalidade, devendo o TCU, então, apreciar e julgar as contas prestadas ou tomadas.

Outrossim, seja para ratificar o entendimento do julgamento das contas das entidades do terceiro setor pelo TCU por serem responsáveis por recursos públicos, seja para restringir este cabimento aos casos de perda, extravio ou outra irregularidade que enseje prejuízo ao erário, qualquer pessoa que, por ação ou omissão, provocar estes fatos, deverá fazê-lo.

Assim, “qualquer pessoa, seja ela agente público ou não, que provocar, por ação ou omissão, perda, extravio ou outra irregularidade que acarrete prejuízo aos cofres públicos terá de prestar contas e as terá julgadas pelo Tribunal de Contas" ${ }^{\text {"438, }}$, por ter sido a $\mathrm{CF} / 88$ enfática, exaustiva e repetitiva a respeito.

\footnotetext{
${ }^{437}$ No mesmo instrumento que traz estas considerações, o TCU praticamente declara-se impedido de exercer suas competências sem a colaboração prévia dos órgãos convenentes: "Cumpre, por fim, destacar, no que diz respeito ao estoque de convênios, contratos de repasse e termos de parceria não analisados, que a demora nos procedimentos de competência dos órgãos e entidades repassadores constitui um gargalo, na verdade um óbice à atuação da $\mathrm{CGU}$, do TCU, do MPF e da AGU, no exercício de suas respectivas competências, uma vez que a atuação desses órgãos deve ser precedida dos seguintes procedimentos, de maneira simplificada:

1. Conclusão dos órgãos e entidades repassadores quanto à correta e regular aplicação dos recursos;

2. Em caso de irregularidades, cobrança para que os convenentes viessem a suprir as irregularidades constatadas;

3. Não supridas tais irregularidades, registro da inadimplência no Siafi;

4. Se ainda assim não supridas as irregularidades, instauração de Tomadas de Contas Especiais (TCE) pelos órgãos e entidades repassadores;

5. Conclusão da TCE, identificando prejuízo à União e a responsabilidade por esse prejuízo;

6. Remessa da TCE para que a CGU aprecie a sua regularidade formal;

7. Remessa da TCE pela CGU ao TCU para julgamento das contas e imputações decorrentes (ressarcimento do dano ou prejuízo e multas aos responsáveis).
}

Somente com esse julgamento é que o MPF será acionado, por meio de representações encaminhadas pelo TCU, para promover as ações cabíveis (penais e de improbidade administrativa), bem como também a AGU para promoção das ações executivas, face aos acórdãos proferidos pelo TCU”. Cf. "Relatório e Pareceres Prévios sobre as Contas do Governo da República - Exercício 2006". Disponível em: <www.tcu.gov.br>. Acesso em: 12 mai 2009.

${ }^{438}$ Márcia Maria Barreto Fernandes Semer. Competências constitucionais do Tribunal de Contas. (cit.), 2000. p. 75. 
Também é controverso o posicionamento no tocante à prestação de contas por parte do causador de prejuízo ao erário. Parte da doutrina assevera: "somente os agentes sujeitos ao dever de prestar contas submetem-se à jurisdição dos Tribunais de Contas. [...] o benefício fraudulento decorrente de ato ilícito praticado exclusivamente pelo particular, não agente público, está fora da jurisdição do Tribunal de Contas” ${ }^{״ 39}$. Apenas se em co-autoria com servidor público causador de lesão aos cofres públicos e se existente expressa disposição legal decorrente de vínculo entre a entidade do terceiro setor e o Estado se poderia falar em prestação de contas às Cortes de Contas em caso de danos ao erário ${ }^{440}$.

Opinamos não haver dúvidas do dever de as entidades do terceiro setor, sejam elas fundações ou associações, prestarem contas ao Tribunal de Contas na forma de relatório de gestão, bem como as terem por ele julgadas, independentemente de causarem prejuízo ao erário.

\subsubsection{Fiscalizar admissão de pessoal}

O inciso III do art. 71 da $\mathrm{CF} / 88^{441}$ contém expressa menção à fiscalização da legalidade da admissão de pessoal ${ }^{442}$, concessão de aposentadoria, reforma ou pensão pela administração direta e indireta, e pelas "fundações instituídas e mantidas pelo Poder Público", salvo atos de nomeação para cargos de provimento em comissão. Em razão dessa atribuição, haverá controle de legalidade de ato administrativo para fins de registro, completando-se apenas com o respectivo registro pelo Tribunal de Contas ${ }^{443}$.

Pela redação e interpretação literal do inciso ora em exame, não haveria possibilidade de controle pelo TCU quanto à admissão e aposentadoria de pessoal contratado pela entidade privada parceira do Estado, sobretudo 'para fins de registro'.

Caberia questionar, no entanto, se seria possível o controle da legalidade de atos de

\footnotetext{
439 Jorge Ulisses Jacoby Fernandes. Tribunais de Contas do Brasil: jurisdição e competência. (cit.), 2005b. p. 506-507.

${ }^{440}$ Ibid., p. 508.

${ }^{441}$ No Regimento Interno do TCU a matéria encontra-se disciplinada nos artigos $1^{\circ}$, VIII, 17, III, 143, II e 259, I e II. Diversamente, no Município de São Paulo, consta de sua Lei Orgânica redação que não previu as fundações instituídas e mantidas pelo Poder Público: “Art. 48. (...) III - apreciar, para fins de registro, a legalidade dos atos de admissão de pessoal, a qualquer título, na administração direta e indireta, excetuadas as nomeações para cargo de provimento em comissão, bem como a das concessões de aposentadorias e pensões, ressalvadas as melhorias posteriores que não alterem o fundamento legal do ato concessório".

${ }^{442}$ De acordo com o art. 37, II e IX da CF/88, os cargos ou empregos públicos deverão ser preenchidos mediante concurso de provas ou provas e títulos, excetuada a possibilidade de contratação por tempo determinado para atendimento de necessidade temporária de excepcional interesse público.

${ }^{443}$ Afonso Gomes Aguiar; Márcio Paiva de Aguiar. O Tribunal de Contas na ordem constitucional. 2. ed. Belo Horizonte: Fórum, 2008. p. 80.
} 
admissão nas fundações e associações privadas sem fins lucrativos, não criadas por lei, mas mantidas com recursos públicos.

A questão é pertinente, pois a Lei das OSCIPs é expressa acerca da possibilidade de remunerar dirigentes com recursos públicos (art. $\left.4^{\circ}, \mathrm{V}\right)$, tendo o TCU já se pronunciado no sentido da não submissão das retribuições ao teto remuneratório fixado para a Administração Pública em coerência ao disposto no art. 34 da Lei n. 10.627/2002 $2^{444}$.

O controle pelos Tribunais de Contas dos atos em comento das entidades do terceiro setor não seria para fins de registro, mas concernente à legalidade de sua efetivação, à luz e em cumprimento à legislação infraconstitucional, não se furtando o TCU ao exercício desta competência $^{445}$.

A discussão envolve a definição pela aplicação integral ou não do regime jurídico de direito público sobre as entidades em comento, em função ou a despeito do volume de recursos públicos recebidos. Para alguns, implicará em dizer não deverem respeitar as limitações previstas na Lei Orçamentária ${ }^{446}$ ou realizarem concurso ou seleção pública para fins de admissão de pessoal.

Não caberia exigir das entidades do terceiro setor a realização de concurso ou seleção pública para admissão de pessoal ${ }^{447}$, por ser incompatível a aplicação do regime público sob este aspecto, a despeito de obrigadas a obedecer a certos princípios (publicidade, igualdade, moralidade etc.). Tampouco deverá proceder, como o faz a administração pública, à remessa de documentos ao TCU para fins de registro dos atos de admissão ou aposentadoria de pessoal integrante de entidade do terceiro setor e, em analogia, também aos casos de pensão e

\footnotetext{
${ }^{444}$ BRASIL. TCU, Acórdão nº 1777/2005 - Plenário, p. 84-85.

${ }^{445}$ A título de exemplo, neste sentido, o Tribunal de Contas da União, em razão de representação formulada pelo Ministério Público, no Acórdão n. 1111/2008-Plenário, examinou irregularidades em processo seletivo destinado à contratação de pessoal por OS, determinando a suspensão cautelar do procedimento, oitiva dos responsáveis e fixação de prazo para anulação, com fulcro no art. 45 de sua Lei Orgânica, na qual consta que "verificada a ilegalidade de ato ou contrato, o Tribunal, na forma estabelecida no Regimento Interno, assinará prazo para que o responsável adote as providências necessárias ao exato cumprimento da Lei [...]" (Disponível em: <http://www.tcu.gov.br>. Acesso em: 03. out. 2008). Por responsável, como se viu, a Corte de Contas já entendeu por incluir as OSs para exercício da competência em comento.

${ }^{446}$ Vide Acórdão TCU n. 1372/2008 - Primeira Câmara, quando se exigiu que organização social deixasse de contratar servidor público para fins de consultoria mediante pagamento de recursos recebidos por meio de convênios ou outros instrumentos congêneres, em respeito a Lei 10.266/2001 - LDO para 2002, inciso VIII do art. 25.

${ }^{447}$ O TCU já se pronunciou a respeito daqueles que devem realizar concurso ou seleção pública, sem incluir as entidades do terceiro setor: "Súmula $\mathrm{n}^{\circ} 231$ A exigência de concurso público para admissão de pessoal se estende a toda administração Indireta, nela compreendidas as Autarquias, as Fundações instituídas e mantidas pelo Poder Público, as Sociedades de Economia Mista, as Empresas Públicas e, ainda, as demais entidades controladas direta ou indiretamente pela União, mesmo que visem a objetivos estritamente econômicos, em regime de competitividade com a iniciativa privada".
} 
$\operatorname{aposentadoria}^{448}$

Atuar em sentido contrário seria violar a liberdade própria das entidades privadas, a ser respeitada por serem parceiras do Estado e não integrantes de sua estrutura. Ainda, conferir ao terceiro setor o mero papel de "longa manus" do Poder Público ou terceirizado não seria condizente com a modelagem pretendida a respeito.

Parece-nos possível, todavia, o controle da legalidade dos atos das entidades do terceiro setor que impliquem despesa ou perda patrimonial, pois "a atuação das Cortes de Contas é pautada pelo princípio da proteção ao erário" ${ }^{449}$. Poderá haver fiscalização, portanto, de contratação pelas entidades do terceiro setor de pessoas impedidas por lei, despesas com pessoal não previstas no instrumento de parceria, indenizações e reembolsos indevidos a voluntariado $^{450}$.

O exercício desta atribuição poderá se dar, por exemplo, em auditoria ou se constatada ilegalidade ou irregularidade de contratação pela entidade de servidores ou agentes públicos expressamente vedadas em lei - como na LDO ou no Decreto Federal n. 6.170/2007: membros dos três poderes, do Ministério Público, do Tribunal de Contas, servidores vinculados ao órgão ou entidade concedente, respectivos cônjuges, companheiros e parentes em linha reta, colaterais ou por afinidade até segundo grau.

\subsubsection{Realizar inspeções e auditorias}

O inciso IV do art. $71 / 88^{451}$ da CF trata da realização, por conta própria ou por solicitação da Câmara dos Deputados, do Senado Federal, de Comissão Técnica ou de inquérito, de auditorias e inspeções pelos Tribunais de Contas sobre as pessoas e órgãos públicos $^{452}$, inclusive os descritos no inciso II. Este preceito legal, como se viu, a depender do

\footnotetext{
${ }^{448}$ O TCU tem se posicionado neste sentido. No Acórdão TCU n. 1952/2007, explicitamente restou consignado que as OSs não deverão realizar concurso público para contratação de pessoal, ainda que devam observar os princípios públicos. Outrossim, o Tribunal de Contas do Estado de São Paulo previu que o órgão parceiro deverá encaminhar a relação dos empregados admitidos ou mantidos com recursos do contrato de gestão celebrado com organização social, indicando as funções e o valor global despendido no período (art. 21, XII da Instrução n. 02-2008).

${ }^{449}$ Afonso Gomes Aguiar; Márcio Paiva de Aguiar. O Tribunal de Contas na ordem constitucional. 2. ed. Belo Horizonte: Fórum, 2008. p. 106.

${ }^{450}$ Neste sentido, vide Acórdão TCU n. 715/2008 - Primeira Câmara.

${ }^{451}$ BRASIL. TCU, Regimento Interno no Tribunal de Contas da União - RITCU. Boletim do Tribunal de Contas da União, Brasília, ano 40, n. 1, fev. 2007, art. 204. Disponível em: http://www.tcu.gov.br. Acesso em: 06 out. 2009.

${ }^{452}$ Segundo Ives Gandra Martins: "Tais inspeções e auditorias incidirão sobre as unidades administrativas dos Poderes Legislativo, Executivo e Judiciário, além daquelas mencionadas no inc. II, ou seja, entidades da
} 
entendimento esposado, poderá ou não abranger o terceiro setor parceiro, segundo a amplitude dada ao conceito de responsáveis pela gestão de recursos públicos ${ }^{453}$.

A interpretação no sentido de a expressão responsáveis incluir as pessoas jurídicas em exame conferiria maior respaldo a inspeções e auditorias sobre elas e se coadunaria aos fins visados pela $\mathrm{CF} / 88$ : zelar pelos recursos públicos, independentemente de seus detentores.

Parte da doutrina não confere interpretação extensiva ao conteúdo do inciso IV sob análise para abarcar as entidades do terceiro setor, posicionando-se na direção de as fiscalizações nele contidas terem "por objeto as unidades administrativas dos três Poderes, assim como fundações e sociedades instituídas e mantidas pelo Poder Público federal"454 ${ }^{\text {. No }}$ sentido de sua possibilidade, Pedro Roberto Decomain aduz caber auditoria em entidades privadas gestoras de recursos públicos ${ }^{455}$.

Adotamos o entendimento de a expressão responsáveis do inciso II, mencionado pelo inciso IV, abarcar as entidades em exame. Seja mediante provocação ou ex officio, os Tribunais de Contas poderão realizar sobre elas inspeções e auditorias de natureza contábil, financeira, operacional e patrimonial - salvo a orçamentária, cabendo-lhes o exame da legalidade, legitimidade e economicidade dos atos, nos parâmetros inicialmente expostos. Admite-se, ainda, com ressalvas, o controle do mérito dos atos sem substituí-los, a fim de examinar, inclusive, a sua economicidade, superando-se o sistema de controle da mera legalidade ${ }^{456}$.

Administração indireta." Celso Ribeiro Bastos; Ives Gandra Martins. Comentários à Constituição do Brasil promulgada em 5 de outubro de 1998. 4. vol - tomo III. Art. 70 a 91.3 ed. atual. São Paulo: Saraiva, 2002. p. 35.

${ }^{453}$ Se adotada interpretação estrita do citado inciso II combinado com o caput do art. 70, estaria ausente qualquer formulação mais precisa tanto da amplitude (legalidade, legitimidade, economicidade) como da extensão (contábil, financeira, orçamentária, operacional e patrimonial) da competência em comento sobre as entidades privadas sem fins lucrativos. Isto porque, o caput do art. $70 \mathrm{da} \mathrm{CF}$, ao estabelecer a amplitude e a extensão da competência do controle externo (a englobar Congresso Nacional e Tribunal de Contas), é claro em asseverar que será assim exercido sobre as entidades da administração direta e indireta e aplicação de subvenção, sem mencionar, ainda que genericamente, as entidades privadas em exame. Pela redação do inciso IV do mesmo artigo, as inspeções e auditorias sofreriam as mesmas "restrições", se interpretado responsáveis em sentido estrito.

Segundo Odete Medauar em posicionamento esposado antes da EC n. 19/98, o art. 71, inciso IV estabelece que as entidades da administração indireta e fundações e sociedades instituídas e mantidas pelo poder público se sujeitam a auditorias. Controle da Administração Pública (cit.), 1990. p. 119.

Outrossim, lembre-se que o parágrafo único do art. 70 da $\mathrm{CF}$, a despeito de se referir às pessoas jurídicas de natureza privada, restringe-se a dispor sobre o dever prestação de contas. Desta forma, até mesmo a competência para realizar auditorias nas organizações em exame poderia sofrer questionamento sob alegação de ausência de respaldo constitucional expresso a fundamentá-la, salvo se interpretado que o controle da "aplicação de subvenção" indicado no art. 70 abarcaria aquela realizada pelas entidades em apreço para fins de fiscalização.

${ }^{454}$ Francisco Eduardo Carrilho Chaves. Controle Externo da Gestão Pública: a fiscalização pelo legislativo e pelos Tribunais de Contas: teoria e jurisprudência. (cit.), 2007. p. 76.

455 Tribunais de Contas no Brasil. São Paulo: Dialética, 2006. p. 113.

${ }^{456}$ Antônio Roque Citadini. O Controle Externo da Administração Pública. São Paulo: Max Limonad, 1995. p. 18-19. 
O TCU tem realizado ampla fiscalização das entidades em análise sob o escólio do inciso $\mathrm{IV}^{457}$, flagrando inúmeras malversações de recursos públicos tidas por regulares pelo próprio controle interno, a demonstrar a importância e imprescindibilidade do controle externo ${ }^{458}$.

\title{
5.1.4 Fiscalizar recursos repassados pela União
}

\author{
O inciso VI do art. 71 da CF/88 estabelece a competência do TCU para fiscalizar a
} aplicação de recursos repassados pela União "a Estado, ao Distrito Federal ou a Município" mediante convênio, acordo ou outro instrumento congênere, não mencionando entidades privadas sem fins lucrativos ${ }^{459}$.

\footnotetext{
${ }^{457}$ No Acórdão n. 707/2008 - Plenário, em razão de solicitação do Congresso Nacional, foi realizada auditoria nos convênios celebrados entre o INCRA e várias entidades do terceiro setor.

${ }^{458}$ Como já destacado, os órgãos públicos parceiros não realizam ou realizam de modo superficial a fiscalização das parcerias celebradas com as entidades em comento, em todas as suas etapas. "A ausência de controle anterior e concomitante torna, conforme o TCU insiste em frisar, praticamente inoperante a fase de controle posterior. Este é o motivo pelo qual a CGU e o TCU, em seus trabalhos de auditoria governamental, identificam uma série de irregularidades em projetos cujas prestações de contas foram aprovadas pelo órgão repassador. Isso ocorre porque esses órgãos de controle, em seus trabalhos de auditoria, verificam não só a regularidade dos comprovantes de despesa, mas analisam, com muito mais rigor do que as unidades técnicas dos órgãos repassadores, os resultados decorrentes da execução dos projetos", conforme Natasha Schmitt Caccia Salinas, Avaliação legislativa no Brasil: um estudo de caso sobre as normas de controle das transferências voluntárias de recursos públicos para entidades do terceiro setor (cit.), 2008. p. 140.
}

Não por outra razão, Célia Cunha Mello é favorável a que "[...] a execução dos contratos de fomento, por exigência legal ou contratual, seja fiscalizada e acompanhada, preferencialmente, de forma direta e próxima, pela entidade estatal fomentadora, de sorte a evitar o desperdício dos recursos públicos empregados, mas, principalmente, com a finalidade de otimizar os resultados pretendidos [... pois] não é interessante se resolver em perdas e danos a relação de fomento." O fomento da Administração pública. Belo Horizonte: Del Rey, 2003, p. 143.

Evandro Martins Guerra ressalta as dificuldades do controle externo em razão da ausência de controle interno: "Outra destacada e conhecida dificuldade é a ausência, na grande maioria dos Municípios brasileiros, da implantação do sistema de controle interno previsto no art. 74 da Constituição, que promova a integração dos três Poderes e forneça o necessário supedâneo ao controle externo." (Os controles externo e interno da Administração pública. [cit.], 2005. p. 132).

A questão é relevante, pois a avaliação da escolha do modelo de parceria com o terceiro setor pode ser comprometida quanto a sua legitimidade sob o viés de que não alcança os fins almejados ou se resume a possibilitar malversações de recursos públicos, em cenário de ausência de qualquer controle ou excesso de controle formal. Nesta esteira: "Se a avaliação das experiências em concreto sob os prismas que são próprios à função de controle se revelar positiva, ter-se-á nisso um importante fundamento de legitimidade de escolha de modelo de execução de atividades públicas não-estatais; por isso a relevância do estudo dos desafios ao controle trazidos por essa nova realidade. [...] é o controle que pode revelar que essa nova arquitetura institucional se revela potencialmente boa - mas esteja a exigir aperfeiçoamentos no plano da aplicação prática". Vanice Lírio Valle. Terceiro setor e parcerias com a Administração pública: desafios ao controle das OS e OSCIPs. Revista de Direito do Terceiro Setor, Belo Horizonte, ano 2, n. 4, jul./dez. 2008. p. 52-53.

${ }^{459} \mathrm{Na}$ esteira da majoritária doutrina, Pedro Roberto Decomain (Tribunais de Contas no Brasil [cit.], 2006) e Francisco Eduardo Carrilho Chaves (Controle externo da gestão pública: a fiscalização pelo legislativo e pelos Tribunais de Contas: teoria e jurisprudência [cit.], 2007), ao tecer comentários especificamente sobre o inciso em comento, não versaram sobre o controle da aplicação dos recursos repassados a entidades privadas sob esta competência dos Tribunais de Contas, restringindo-se a comentar as transferências a entes públicos. No Estado e 
É cediço, entretanto, poder a União repassar recursos às ONGs por intermédio de Estado, Distrito Federal e Município ou diretamente, firmando parcerias.

Para a primeira hipótese, pode-se interpretar pelo exercício de controle indireto do TCU sobre as entidades privadas sem fins lucrativos, quando do exame do repasse realizado por um dos entes receptores dos recursos federais a estas organizações ${ }^{460}$. O controle seria sobre os entes da federação, não sobre as entidades privadas em comento.

Opinamos pela possibilidade de a fiscalização incidir diretamente sobre as pessoas jurídicas em comento ${ }^{461}$, por força da expressão constitucional "fiscalização da aplicação de quaisquer recursos" repassados pela União, mesmo se transferida por intermédio de ente federativo. Por força da nova redação do parágrafo único do art. 70 da $\mathrm{CF} / 88$, outra interpretação não se faz admissível ${ }^{462}$.

Para o segundo caso, em analogia ao preceito constitucional em comento, o controle caberia - e diretamente - sobre as aplicações de recursos transferidos por meio de parcerias celebradas entre a União e o terceiro setor, sem a intermediação do Estado, do Município ou do Distrito Federal.

Convém examinar o tratamento da questão em outras esferas e pela legislação infraconstitucional.

no Município de São Paulo, os respectivos Tribunais de Contas trataram diversamente a matéria, seja para ampliar ou restringir sua abrangência.

460 “Justifica-se a fiscalização do repasse? E se justificaria a fiscalização sobre a aplicação? Sobre o repasse não há dúvida. Todo o dinheiro público tem que ter aplicação correta, adequada e legal, razão pela qual ao Tribunal de Contas, órgão técnico para a fiscalização, cabe, naturalmente, verificar de sua pertinência. [...]. Se o repasse decorrer de política de colaboração, à nitidez, por não ser obrigatório o repasse, mas decorrer de acordo, entendo que não só o repasse, mas a aplicação, estão sujeitos à apreciação do Tribunal de Contas. [...]. Entendo, todavia, que o final da dicção 'outros instrumentos congêneres' justificaria o entendimento de que os repasses obrigatórios e facultativos foram contemplados na 'dicção constitucional', visto que 'congênere' é mais do que sinônimo de 'equivalente', podendo ser tomado por 'semelhante' e a semelhança pode-se dar no objeto da operação que é o repasse, independentemente do instrumento legal ou convencional adotado. Reconheço, todavia, não ser a minha interpretação majoritária, embora com maior poder de responsabilizar os agentes governantes, por eventuais distorções e desvios, do que a interpretação restritiva, que apenas se aplicaria aos responsáveis por repasses acordados”. Celso Ribeiro Bastos; Ives Gandra Martins. Comentários à Constituição do Brasil - promulgada em 5 de outubro de 1998. 4. vol. - tomo III. Art. 70 a 91. 3.ed. atual. São Paulo: Saraiva, 2002. p. 45-48.

${ }^{461}$ Neste sentido, o Acórdão TCU n. 535/2008- Plenário, no contexto da "CPI das ONGs". Também foi o caso do Acórdão n. 2066/2006-Plenário, cuja natureza consistiu em exame de relatório de auditoria realizada com o objetivo de verificar a regularidade da aplicação de recursos federais repassados pela União ou entidades da Administração Indireta a ONG, por meio de convênios, contratos de repasse e instrumentos similares. Como outro exemplo, o Acórdão n. 1933/2007-Plenário (Relatório de Auditoria) teve por objeto verificar a regularidade dos instrumentos de transferência de recursos públicos para execução de projetos relacionados com a promoção do tema Inclusão Digital, período 2004-2006.

${ }^{462}$ Para Carlos Vasconcelos Domingues, a nova redação do parágrafo único do art. 70 enseja a necessidade de reinterpretação do inciso VI do art. 71 da CF para incluir parcerias celebradas com organizações sociais convênios, acordos, ajustes e outros instrumentos congêneres. O controle externo e novos modelos de gestão de serviços públicos: as organizações sociais. Salvador: Tribunal de Contas do Estado da Bahia, 2000. 
Na legislação infraconstitucional federal do Estado e do Município de São Paulo ${ }^{463}$, ampliou-se ou regulamentou-se a competência dos Tribunais de Contas para fiscalizar os recursos e os respectivos instrumentos de repasse celebrados com entidades privadas.

Segundo o Regimento Interno do TCU (art. 254) a

\begin{abstract}
fiscalização da aplicação de quaisquer recursos repassados pela União, autarquias, fundações instituídas e mantidas pelo poder público e demais órgãos e entidades da administração pública federal mediante convênio, acordo, ajuste ou outros instrumentos congêneres a estado, ao Distrito Federal, a município e a qualquer outra pessoa, física ou jurídica, pública ou privada, será feita pelo Tribunal por meio de levantamentos, auditorias, inspeções, acompanhamentos ou monitoramentos, bem como por ocasião do exame dos processos de tomadas ou prestações de contas da unidade ou entidade transferidora dos recursos (g.n.).
\end{abstract}

Neste sentido, ainda que incidentalmente, o TCU poderá realizar fiscalização direta sobre os termos de parceria e instrumentos congêneres, nos termos do art. 41 , inciso $\mathrm{IV}^{464}$ da Lei Orgânica do Tribunal de Contas da União ${ }^{465}$.

Assim, o TCU deve verificar se os recursos federais transferidos estão sendo efetivamente utilizados para os fins estipulados no instrumento de parceria, seja por meio de inspeções e auditorias, seja mediante tomada ou prestação de contas da entidade transferidora (Regimento Interno do Tribunal de Contas da União - RITCU art. 198 e 199) ou tomadora de recursos públicos.

A constitucionalidade do art. 254 do RITCU, no entanto, foi questionada por alguns autores, por extrapolar a competência outorgada ao TCU pelo inciso VI do art. 71 da CF/88. Alegou-se, inclusive, a usurpação de competência de outras Cortes de Contas, com risco de decisões conflitantes quando da fiscalização da gestão dos recursos públicos federais repassados por intermédio de Estado ou Município a entidade da administração indireta destes - e em analogia, às entidades do terceiro setor ${ }^{466}$.

463 A abrangência do preceito constitucional foi ampliado pela Constituição do Estado de São Paulo no art. 33,
VII : “fiscalizar a aplicação de quaisquer recursos repassados ao Estado e pelo Estado, mediante convênio,
acordo, ajuste ou outros instrumentos congêneres;” (g.n.). O Regimento Interno do TCE-SP (LC n. 709/93)
também não distinguiu a quem o Estado teria repassado os recursos para fins de fiscalização: “Art. 2. (...) X -
fiscalizar a aplicação de quaisquer recursos repassados pelo Estado, mediante convênio, acordo, ajuste ou
instrumento congênere;”. Na Lei Orgânica do Município de São Paulo no art. 48, V, cuja redação foi clara em
prever fiscalização sobre aplicação de recursos repassados ao Município - e não por este a terceiros,
invertendo a intenção do constituinte.
464 “Art. 41 . [...] IV - fiscalizar, na forma estabelecida no Regimento Interno, a aplicação de quaisquer recursos
repassados pela União mediante convênio, acordo, ajuste ou outros instrumentos congêneres, a Estado, ao
Distrito Federal ou a Município”.
465 Benjamin Zymler. Direito Administrativo e Controle. (cit.), 2005. p. 311 .
466 Carmen Dulce Montanhero; Luiz Antonio Tavolaro; Luiz Antonio Guerra. Limites à Atuação do Tribunal de 
De toda forma, o TCU, na Decisão n. 931/99-Plenário, entendeu pela competência para fiscalizar diretamente os termos de parceria e contratos de gestão celebrados entre órgão público parceiro e OSCIPs e OSs, respectivamente ${ }^{467}$.

A ausência de previsão expressa de entes privados na redação do art. 71, inciso VI da CF/88 não impediu o referido posicionamento pelo TCU. Parece, ainda, ser hipótese de desatualização da $\mathrm{CF} / 88$ em face das inúmeras transferências de recursos públicos ao terceiro setor que vêm ocorrendo e da necessidade de seu amplo controle.

Porque incompatível com os fundamentos do controle externo, não se poderia aceitar a proposital intenção do constituinte de não autorizar o controle dos recursos públicos repassados a entidades privadas sem fins lucrativos em exame - até porque não diferem dos transferidos aos Estados e Municípios. Na esteira de Carlos Vasconcelos Domingues, diante do parágrafo único do art. 70, há que se reinterpretar o inciso VI do art. 71, a fim de incluir também os instrumentos celebrados com as organizações sociais ${ }^{468}$ - e com as demais entidades privadas a nosso ver ${ }^{469}$.

\subsubsection{Aplicar sanções e determinar prazo para adoção de medidas}

De acordo com o inciso VIII do art. 71 da CF/88, o TCU poderá aplicar sanções definidas em lei "aos responsáveis" se concluir pela existência de alguma irregularidade ou ilegalidade nas contas, atos ou contratos fiscalizados ${ }^{470}$, previsão esta reiterada em outras

Contas da União - Convênio - Repasse de Recursos da União - Inconstitucionalidade do $\S 1^{\circ}$, do art. 254, do RITCU - Risco de Decisões Díspares e Inexeqüíveis - Questionamento Judicial da Decisão. In: Licitações e contratos administrativos. Eduardo Arruda Alvim; Luiz Antonio Tavolaro. Curitiba: Juruá, 2006. p. 327-340.

${ }^{467}$ No Estado de São Paulo, o tratamento da Lei Complementar n. 709/93 relativa ao TCESP previu a sua competência para julgar os instrumentos de "convênios, aplicação de auxílios, subvenções ou contribuições concedidos pelo Estado e pelos Municípios a entidades particulares de caráter assistencial ou que exerçam atividades de relevante interesse público" (art. $2^{\circ}$ XVII). Neste sentido, no "Manual Básico - Repasses Públicos ao Terceiro Setor" constou a físcalização pelo TCE-SP de contrato de gestão e termo de parceria. Ainda que se alegue a competência para mero julgamento da legalidade e regularidade dos instrumentos, parece-nos abrir a possibilidade para fiscalização dos recursos por meio deles repassados, mediante a interpretação sistemática do inciso X, art. $2^{\circ}$ da Lei Complementar n. 709/93.

468 Carlos Vasconcelos Domingues. O controle externo e novos modelos de gestão de serviços públicos: as organizações sociais. Salvador: Tribunal de Contas do Estado da Bahia, 2000. p. 138. Disponível em: http://www.tce.ba.gov.br, Acesso em: 22 mai. 2009.

469 A reiterar este entendimento, com a Emenda Constitucional n. 19/98, parece-nos que a intenção do constituinte reformador foi outorgar competência às Cortes de Contas para fiscalizar os bens públicos das respectivas esferas federal, estadual e municipal, respectivamente, independentemente de quem os detenha (art. 70, parágrafo único c/c art. 75), pelo que não seria razoável que somente pudesse fiscalizar a transferência pela União de recursos aos Estados, Municípios e Distrito Federal e não as entidades do terceiro setor.

470 A Lei Orgânica do TCU consignou: “Art. 56. O Tribunal de Contas da União poderá aplicar aos administradores ou responsáveis, na forma prevista nesta lei e no seu regimento interno, as sanções previstas 
esferas federais e leis orgânicas dos Tribunais ${ }^{471}$.

Desta feita, se previsto em lei - como a própria Lei Orgânica ${ }^{472}$ do TCU, haverá competência deste para aplicar sanções aos responsáveis integrantes do terceiro setor, pois não havendo sanção, qualquer decisão daquele órgão redundaria em mera recomendação ${ }^{473}$. Nota-se que o intérprete, a depender da extensão atribuída à palavra responsáveis ampliará ou restringirá o alcance do inciso em comento ${ }^{474}$.

O assunto será aprofundado na sétima parte.

Se não bastasse, sob postura orientadora das Cortes de $\operatorname{Contas}^{475}$, previu a $\mathrm{CF} / 88$, no inciso IX do artigo 71, a determinação de prazo para “órgão ou entidade" adotar medidas necessárias ao exato cumprimento da lei, uma vez verificada ilegalidade e ineficiência, referindo-se às entidades da administração direta e indireta, segundo Ives Gandra Martins ${ }^{476}$.

$\mathrm{O}$ TCU, todavia, já estendeu o conteúdo deste inciso às entidades privadas sem fins

neste capítulo".

${ }^{471}$ A Lei Orgânica do Município de São Paulo estabeleceu redação diversa: “Art. 48 (...) VIII - aplicar aos responsáveis as sanções previstas em lei, em caso de ilegalidade de procedimento no que tange às receitas, despesas ou irregularidades das contas". No âmbito do TCE-SP, a Lei Complementar n. 709/93, Art. $2^{\circ}$, inciso XII estabeleceu a competência deste de aplicar aos responsáveis, em caso de ilegalidade de despesa ou irregularidade de contas, as sanções previstas em lei, motivo pelo qual não nos parece excluir as entidades parceiras do terceiro setor. Na Constituição do Estado de São Paulo, o art. 33, inciso IX previu: "aplicar aos responsáveis, em caso de ilegalidade de despesa ou irregularidade de contas, as sanções previstas em lei, que estabelecerá, entre outras cominações, multa proporcional ao dano causado ao erário”.

${ }^{472}$ Em sentido contrário: "Não têm qualquer respaldo jurídico as sanções previstas nos regimentos internos dos Tribunais de Contas". Afonso Gomes Aguiar; Márcio Paiva de Aguiar. O Tribunal de Contas na ordem constitucional. 2. ed. Belo Horizonte: Fórum, 2008. p. 70.

${ }^{473}$ Helio Saul Mileski. O Controle da gestão pública. (cit.), 2003. p. 328.

${ }^{474}$ A simples previsão na $\mathrm{CF}$ da expressão responsáveis parece indicar que não se pretendeu restringir a fiscalização de competência das Cortes de Contas à administração direta ou indireta, reforçado este entendimento pela já mencionada legislação especial aplicável as entidades em comento e pelo fato de que os órgãos em exame não se constituírem em última esfera decisória, que apenas aplica sanções aos responsáveis. Pelo contrário, para que sancione, como versado nos tópicos anteriores, poderá exercer todo o leque de competências que lhe foram atribuídas, com vistas a verificar casos de irregularidade e ilegalidade.

475 Márcia Maria Barreto Fernandes Semer. Competências constitucionais do Tribunal de Contas. (cit.), 2000. p. 98.

${ }^{476}$ Neste sentido, Ibid., 2000. p. 97.

Celso Ribeiro Bastos e Ives Gandra Martins ressaltam: "Por outro lado, ao falar em órgão ou entidade, quis o constituinte, evidentemente, vincular o poder fiscalizador do Tribunal de Contas a exercê-lo sobre a Administração direta (órgão) ou indireta (entidade). Há de se compreender que à nitidez, o prazo determinado para voltar à legalidade é dado àquelas pessoas que exercem funções públicas ou ocupam cargos na Administração indireta, sendo estes os responsáveis. É de se lembrar que a ilegalidade pode ter sido praticada por outras pessoas no exercício de idênticas atribuições, assim se justificando a utilização do vocabulário referente à própria instituição e não às pessoas que a administram”. Celso Ribeiro Bastos; Ives Gandra Martins. Comentários à Constituição do Brasil - promulgada em 5 de outubro de 1998. 4. vol - tomo III. Art. 70 a 91.3 ed. atual. São Paulo: Saraiva, 2002. p. 59-60. 
lucrativos $^{477}$, fazendo-o, muitas vezes, em conjunto com a sustação, a ser objeto do tópico seguinte.

Parece-nos possível que as determinações dos Tribunais de Contas recaiam sobre o terceiro setor de modo direto ${ }^{478}$.

\subsubsection{Sustar atos impugnados e representar}

Caso as providências determinadas pelos Tribunais de Contas não sejam adotadas, o art. $71, \mathrm{X}$, da $\mathrm{CF} / 88^{479}$ previu a possibilidade de sustar a execução do ato ${ }^{480}$ impugnado. Aquele Tribunal poderá fazê-lo antes de inteiramente concluído ${ }^{481} \mathrm{o}$ ato de descumprimento efetivo de sua determinação ${ }^{482}$, comunicando imediatamente a decisão à Câmara dos Deputados e ao Senado Federal, a fim de que se manifeste a respeito - inclusive para não confirmar a suspensão.

Para Pedro Roberto Decomain, a verificação de irregularidade em ato sujeito à fiscalização dos Tribunais de Contas pode ocorrer quando tais atos forem submetidos à sua apreciação por força dos incisos I a III do art. 1, da CF/88, “ou cuja prática tenha chegado ao seu conhecimento quando da realização de inspeções e auditorias, nos termos do inciso IV,

\footnotetext{
${ }^{477}$ No Acórdão n. 2261/2005 - Plenário, o TCU determinou que o ITERRA observasse os preceitos legais da L. 8.666/93, IN n. 01/97, dentre outros, sobretudo quanto à realização de procedimento licitatório, quando couber, para dispêndio de recursos públicos por ele recebidos. Neste caso não foi concedido prazo para seu cumprimento, entendendo-se como de aplicação imediata.

${ }^{478}$ Ressalta-se que não têm sido raras as determinações do TCU no sentido de determinar - ou meramente recomendar - que Ministérios e Secretarias adotem certos procedimentos regulatórios e fiscalizatórios do terceiro setor, sendo emblemático o Acórdão n. 2066/2006 - Plenário, que determinou ao Ministério do Planejamento, Orçamento e Gestão a implementação de sistema de informática em plataforma web que permitisse o acompanhamento on-line dos instrumentos jurídicos utilizados para transferir recursos federais a ONGs (hoje o "Portal dos Convênios"). No Acórdão n. 1777/2005-Plenário, o TCU determinou que o Ministério de Planejamento, Orçamento e Gestão e a Casa Civil orientassem os órgãos e entidades da Administração Pública que incluam nos Termos de Parceria já celebrados ou a celebrar, cláusula contendo previsão de que a OSCIP não poderá utilizar recursos públicos em gastos vedados pela Lei de Diretrizes Orçamentárias (p. 86).

479 Também a Constituição do Estado de São Paulo (art. 33, XI) e Lei Orgânica do Município de São Paulo (art. $48, \mathrm{X})$.

${ }^{480}$ Para Emerson Gabardo, “Quanto aos atos ineficientes, a sustação cabe ao Tribunal de Contas da União. Aliás, cabe aos TCs em geral, em auxílio ao Poder Legislativo e na sua função de controle da eficiência das ações do Estado, verificar o manejamento que faz o gestor público de sua responsabilidade e capacidade funcionais. Ou seja, deve ser exigida a persecução dos melhores resultados com os meios disponíveis, a fim de ser atendido o interesse público, ainda que retorno financeiro algum decorra dos recursos empregados. Controle este que já tem sido exercido, conforme observa-se na 'jurisprudência' do Tribunal de Contas da União, mas que a partir da EC n. 19/98 estende-se tanto às pessoas físicas quanto jurídicas, pública ou privadas." Princípio Constitucional da Eficiência Administrativa. São Paulo: Dialética, 2002. p. 112.

${ }^{481}$ Pedro Roberto Decomain. Tribunais de Contas no Brasil. (cit.), 2006. p. 127.

${ }^{482}$ BRASIL. STF. MS n. 24.510-7 DF de 19.11.2003. Min. Ellen Gracie.
} 
daquele mesmo artigo." $" 483$

Reforça essa atribuição do TCU a legislação federal pertinente às OSs e OSCIPs, ao determinarem o dever de se noticiá-lo de irregularidade ou ilegalidade, para tomar as medidas cabíveis. Há de se ter cautela para não atribuir ao terceiro setor as mesmas responsabilidades e restrições pertinentes à administração pública direta ou indireta, deturpando lógica de colaborador e não integrante da Administração Pública.

Os atos do terceiro setor tidos por irregulares ou ilegais poderiam ser objeto de direta determinação de sua sustação pelo Tribunal de Contas, sem intermediação do órgão parceiro? Ainda, entendendo-se os acordos colaborativos não como contratos administrativos, questiona-se a possibilidade de sua sustação pelas Cortes de Contas, bem como os contratos celebrados entre a entidade privada beneficiada e terceiros, mesmo porque podem decorrer de pregão na forma eletrônica por força do Decreto Federal n. 5.504/05.

Na esteira de Márcia Pelegrini, as atribuições do TCU são destinadas a viabilizar o desempenho da sua função de controle ${ }^{484}$ e a excepcional suspensão de ato das entidades privadas sem fins lucrativos pertinentes a aplicação de recursos públicos a ela concedidos, entendemos, coaduna-se a este posicionamento. Já decidiu o $\mathrm{TCU}^{485}$ positivamente a respeito. A sustação caberia, assim, não para cumprimento de legalidade estrita, por exemplo, mas efetivamente para os casos passíveis de dano ao erário.

Todavia, a interpretação do preceito constitucional não autoriza o TCU a sustar contratos celebrados pela entidade com terceiros privados ${ }^{486}$, tampouco convênios, contratos

\footnotetext{
${ }^{483}$ Pedro Roberto Decomain. Tribunais de Contas no Brasil (cit.), 2006. p. 126.

${ }^{484}$ Márcia Pelegrini. A Competência Sancionatória do Tribunal de Contas no exercício da função controladora: contornos constitucionais. (cit.), 2008, p. 106.

485 Como já citado, o Tribunal de Contas da União, em razão de representação formulada pelo Ministério Público, no Acórdão n. 1111/2008-Plenário, examinou irregularidades em processo seletivo destinado à contratação de pessoal por organização social, determinando a suspensão cautelar do procedimento, oitiva dos responsáveis e fixação de prazo para anulação, com fulcro no art. 45 de sua Lei Orgânica, na qual consta que "verificada a ilegalidade de ato ou contrato, o Tribunal, na forma estabelecida no Regimento Interno, assinará prazo para que o responsável adote as providências necessárias ao exato cumprimento da Lei [...]”. Disponível em: <http://www.tcu.gov.br>. Acesso em: 03. out. 2008
}

${ }^{486}$ A doutrina é unânime no sentido de que esta competência não se estende aos contratos administrativos - ainda que as Cortes de Contas possam examiná-los, determinar prazo para regularização. Nesta senda, a Lei Orgânica do TCU previu que: "Art. 45. Verificada a ilegalidade de ato ou contrato, o Tribunal, na forma estabelecida no regimento interno, assinará prazo para que o responsável adote as providências necessárias ao exato cumprimento da lei, fazendo indicação expressa dos dispositivos a serem observados. $\S 1^{\circ}$ No caso de ato administrativo, o Tribunal, se não atendido: I - sustará a execução do ato impugnado".

Também não se estende a anulação por força do inciso IX do art. 71 da CF. (Cf. Afonso Gomes Aguiar; Márcio Paiva de Aguiar. O Tribunal de Contas na ordem constitucional. 2.ed. Belo Horizonte: Fórum, 2008. p. 109) e na esteira do STF (Mandado de Segurança n 23.550-DF) - vez que somente podem ser sustados por ação direta do Congresso Nacional, salvo se este não se manifestar em noventa dias $\left(\S 2^{\circ}\right)$. 
de gestão, termos de parceria, contratos de repasse celebrados entre a entidade e o órgão público parceiro. Neste sentido, sem mencionar as entidades do terceiro setor, Ives Gandra Martins posiciona-se pela restrição da competência de sustação pelo TCU de contratos também aos instrumentos de pactuação nas relações de coordenação ${ }^{487}$. No mesmo sentido, para Pedro Roberto Decomain, os convênios celebrados entre órgãos públicos ficariam sujeitos à mesma sistemática constitucional ${ }^{488}$.

O TCU já determinou, cautelarmente, à OSCIP suspender todos os atos atinentes a termo de parceria celebrado, à exceção dos referentes a eventos já iniciados, até decisão de mérito pela Corte. Não determinou a suspensão do termo de parceria, mas dos atos dele decorrentes $^{489}$.

\footnotetext{
A CF/88 dispõe que, decorridos os 90 dias, o TCU decidirá a respeito, o que para Luís Roberto Barroso não o autoriza a suspender contratos, mas somente decidir a respeito da legalidade do contrato e das despesas (Tribunal de Contas: algumas competências controvertidas. Rio de Janeiro: Renovar, 2001. p. 238. (Temas de Direito Constitucional).

De acordo com Pinto Ferreira, a "cautela com respeito aos contratos deve-se a que eles têm um caráter de pluralidade ou de bilateralidade" (Pinto Ferreira. Comentários à Constituição Brasileira. 3 ed. arts 51 a 91. Saraiva: São Paulo, 1992. p. 423), o que nos parece não impedir que, em caso de constatação de desfalque, o procedimento seja convertido em tomada de contas especial (Cf. Art. 47. Ao exercer a fiscalização, se configurada a ocorrência de desfalque, desvio de bens ou outra irregularidade de que resulte dano ao erário, o Tribunal ordenará, desde logo, a conversão do processo em tomada de contas especial, salvo a hipótese prevista no art. 93 desta lei. Parágrafo único. O processo de tomada de contas especial a que se refere este artigo tramitará em separado das respectivas contas anuais).

487 Celso Ribeiro Bastos; Ives Gandra Martins. Comentários à Constituição do Brasil - promulgada em 5 de outubro de 1998. 4. vol - tomo III. Art. 70 a 91.3 ed. atual. São Paulo: Saraiva, 2002. p. 72-73.

${ }^{488}$ Pedro Roberto Decomain. Tribunais de Contas no Brasil. (cit.), 2006. p.136.

${ }^{489}$ BRASIL. TCU. Acórdão n. 1386-2009 - Plenário. Min. Relator André Luís de Carvalho. p. 02 Disponível em: $<$ http//:www.tcu.gov.br>. Acesso em: 29/07/2009.
} 


\section{OPERACIONALIZAÇÃO DO CONTROLE}

O objeto desta sexta parte consiste no exame do modo como se dá o exercício das atribuições do TCU sobre as entidades privadas sem fins lucrativos, identificando a iniciativa para se desencadear o controle, os momentos de sua incidência e os procedimentos aplicáveis.

Por estarem intrinsecamente interligadas, algumas questões abordadas nos tópicos anteriores serão relembradas, porém, ora de forma sintética, ora aprofundada.

\subsection{Classificação quanto ao controle}

Os doutrinadores adotam inúmeras classificações a respeito do controle pelos Tribunais de Contas. Para o fim desta dissertação, interessa-nos somente a análise de como se desencadeia e os momentos de sua efetivação.

\subsubsection{Quanto à iniciativa para se desencadear}

O exercício de controle pelas Cortes de Contas pode ser iniciado por provocação ou de ofício.

\subsubsection{Controle mediante provocação}

O modo pelo qual foi organizada a fiscalização constante das leis orgânicas, dos regimentos internos, instruções e decisões normativas dos Tribunais de Contas faz com que o controle das entidades do terceiro setor gestoras de recursos públicos seja mediante provocação, muito mais do que de ofício.

Pelo fato de o TCU adotar entendimento pela não obrigatoriedade das entidades em comento lhe prestarem contas diretamente, a análise destas se fará, de modo geral, em casos de provocação ou percepção de indícios de irregularidade. Tais provocações podem decorrer de iniciativa de pessoa física ou jurídica.

Segundo o art. $74, \S 4^{\circ}$ da $\mathrm{CF} / 88$, qualquer cidadão, partido político, associação ou sindicato é parte legítima para denunciar irregularidades ou ilegalidades às Cortes de Contas, 
obedecidos os requisitos legais ${ }^{490}$.

Os responsáveis pelo controle interno, por sua vez, ao tomarem conhecimento de irregularidade ou ilegalidade, darão ciência aos respectivos Tribunais de Contas, sob pena de responsabilidade solidária (art. $74, \S 3$ da $\mathrm{CF} / 88)^{491}$.

Com redação similar, a Lei das OSs disciplinou o tema. A Lei das OSCIPs estabeleceu aos responsáveis pela físcalização do termo de parceria (“órgão do Poder Público da área de atuação correspondente à atividade fomentada" e "Conselhos de Políticas Públicas das áreas correspondentes de atuação") a obrigação de, ao tomarem conhecimento de qualquer irregularidade ou ilegalidade pela organização parceira na utilização de recursos ou bens de origem pública, dar ciência ao Tribunal de Contas, sob pena de responsabilidade solidária (art. 12).

Ainda, a Câmara dos Deputados, o Senado Federal, Comissão Técnica ou de Inquérito poderão provocar a realização de inspeções e auditorias pelos Tribunais de Contas nas pessoas responsáveis pela gestão de recursos públicos (art. 71, inciso IV, da CF/88) ou que tenham dado causa a perda, extravio ou outra irregularidade resultante em prejuízo ao erário, incluindo a nosso ver as entidades do terceiro setor em exame (RITCU, art. 232).

O RITCU elencou explicitamente as pessoas competentes para representar ${ }^{492}$ ao TCU: o Ministério Público da União ${ }^{493}$; os órgãos de controle interno, os senadores, deputados federais, estaduais e distritais, juízes, servidores públicos e outras autoridades que comuniquem irregularidades por elas conhecidas em virtude do cargo ocupado; os Tribunais de Contas dos estados, do Distrito Federal e dos municípios, as câmaras municipais e os ministérios públicos estaduais; as equipes de inspeção ou de auditoria (art. 246); as unidades técnicas do Tribunal; e outros órgãos, entidades ou pessoas detentoras dessa prerrogativa por força de lei específica.

\footnotetext{
${ }^{490}$ No Regimento Interno do TCU (art. $1^{\circ}$, XXIV) e na Lei Complementar n. 709/93 (art. $2^{\circ}$, XXIV) para o TCE-SP conta idêntica redação.

${ }^{491} \mathrm{O}$ citado preceito possui baixa efetividade, ante a reiterada constatação do TCU de que: "importante a ser destacado refere-se ao descontrole na área administrativa e na de formalização de convênios, bem como à ineficácia do controle interno da entidade, que, conforme demonstrado, não tem capacidade operacional para atuar de forma tempestiva". Cf. Relatório de Auditoria de Conformidade objeto do Acórdão TCU n. 2697/2008 - Plenário, Ministro Relator. Valmir Campelo.

${ }^{492}$ A representação guarda semelhança com a denúncia, que será objeto de análise adiante. Possui procedimento e requisitos de admissibilidade similares, tendo como diferença o rol de legitimação ativa e a ausência de sigilo em sua tramitação. Cf. Francisco Eduardo Carrilho Chaves. Controle externo da gestão pública: a fiscalização pelo legislativo e pelos Tribunais de contas: teoria e jurisprudência. (cit.), 2007. p. 264.

${ }^{493}$ No RITCU há inúmeros preceitos legais que disciplinam a atuação do Ministério Público junto ao TCU (art. 62 , dentre outros). Vide Acórdão TCU n. 1232/2008 - Plenário quanto a representação de subprocurador geral do TCU contra possíveis irregularidades na celebração de convênios e contratos de repasse por parte do Ministério do Turismo com diversas entidades privadas (sindicatos e igrejas), em ofensa às LDOs então vigentes.
} 
De se notar poder a provocação advir, inclusive, de unidades técnicas do próprio TCU, ao constatarem ou vislumbrarem irregularidade ou ilegalidade, ensejando a instauração de fiscalização mediante inspeções, auditorias, dentre outras modalidades. Parece-nos haver, neste caso, em verdade, uma atuação de ofício do TCU, ainda que decorrente de representação, por ter como autor equipe ou unidade técnicas dela integrantes. É o que será objeto do tópico seguinte.

\subsubsection{Controle de ofício}

Os Tribunais de Contas também podem atuar de ofício, dando início a atos de natureza investigativa "de predominante caráter inquisitório, à semelhança de um inquérito investigatório, com impulsos próprios" ${ }^{\mathrm{494}}$.

A fiscalização poderá decorrer de sorteio, de proposição de auditoria por parte dos corpos técnicos do TCU, de desdobramento de indícios de irregularidades verificados em outros procedimentos, quando da análise das Contas do Chefe do Poder Executivo e outras entidades sob sua jurisdição, de "[...] notícias de jornal, matérias veiculadas na televisão"495, dentre outros.

Esta competência está fundamentada no RITCU (art. 230): “O Tribunal, no exercício de suas atribuições, poderá realizar, por iniciativa própria, fiscalizações nos órgãos e entidades sob sua jurisdição, com vistas a verificar a legalidade, a economicidade, a legitimidade, a eficiência, a eficácia e a efetividade de atos, contratos e fatos administrativos" (g.n.).

Não só a instauração de fiscalização poderá ser realizada de ofício, mas outros atos, como a determinação cautelar de afastamento temporário de responsável, "se existirem indícios suficientes de que, prosseguindo no exercício de suas funções, possa retardar ou dificultar a realização de auditoria ou inspeção, causar novos danos ao erário ou inviabilizar o seu ressarcimento" (art. 273, RITCU).

Também de ofício, o relator de processo em trâmite no TCU poderá determinar o "sobrestamento do julgamento, a citação ou a audiência dos responsáveis, ou outras providências consideradas necessárias ao saneamento dos autos, fixando prazo, na forma estabelecida no regimento interno, para o atendimento das diligências" (art. 11, Lei Orgânica).

Por fim, como se verificará oportunamente, o TCU poderá determinar, de ofício, a

\footnotetext{
${ }^{494}$ Sebastião Baptista Affonso. Evolução do controle externo. Revista do Tribunal de Contas da União, Brasília, n. 99, jan./mar. 2004, p. 15-20. p. 18.

${ }^{495}$ BRASIL. TCU, Convênios e Outros Repasses, 2008, p. 61.
} 
instauração do procedimento de Tomada de Contas Especial - TCE.

\subsubsection{Quanto ao momento}

Outra questão merecedora de abordagem é aquela relativa aos momentos de incidência de fiscalização sobre os instrumentos de parceria e o repasse de recursos às entidades privadas do terceiro setor, a despeito de a sistemática de controle dos Tribunais de Contas ser predominantemente a posteriori, não os impedindo de exercer controle a priori ou concomitante aos $\operatorname{atos}^{496}$.

O tópico terá como base a $\mathrm{CF} / 88$ e a legislação federal específica do terceiro setor, para delas extrair o objeto de fiscalização do TCU, conforme as etapas do controle (a priori, concomitante e a posteriori), justificando-se, para fins didáticos, a sua divisão de acordo com estes momentos $^{497}$.

$\mathrm{Na}$ esteira das competências examinadas anteriormente, o conteúdo dos tópicos analisados a seguir poderá ser objeto de controle pelo TCU.

Observe-se não se confundirem o momento com o objeto do controle: nada obsta seja este realizado a posteriori, mas verse sobre a legalidade e atendimento aos requisitos à seleção da entidade ou celebração de parceria. Não se ignora, com isso, por exemplo, a impossibilidade de as prestações de contas, por sua própria natureza, serem objeto de fiscalização a priori, não impedindo que outras questões - como observância das cláusulas obrigatórias em convênios sejam fiscalizadas concomitantemente a sua celebração, ou a posteriori.

Vale esclarecer ter a legislação federal disciplinado a relação do Estado com o terceiro setor de inúmeras maneiras, dentre elas mediante a qualificação ou certificação da entidade, a celebração de parcerias e a análise da prestação de suas contas ${ }^{498}$.

\footnotetext{
${ }^{496}$ O TCE-SP assim se manifestou a respeito: “[...] a fiscalização exercida por este ou qualquer outro Tribunal de Contas se faz, em atenção ao sistema de controle externo praticado no Brasil, de forma 'a posteriori', isto é, controla a licitude e economicidade dos atos de seus jurisdicionados, após sua realização, sendo o controle 'a priori' apenas excepcional e, assim deve ser utilizado com a devida cautela e parcimônia, sob pena de deturpar o próprio sistema”. Cf. Acórdão no TC n. 18973/026/09. DOE 26/06/2009.

${ }^{497}$ Parece-nos oportuna esta divisão, pois, em especial quando da realização de auditoria, o TCU tem analisado como o órgão parceiro estruturou e fiscaliza os recursos repassados por meio de transferências voluntárias, conferindo todas as etapas para celebração e execução de parceria e respectivo controle. No Acórdão n. 1562/2009 - Plenário, o TCU concluiu que: “[...] são generalizados no âmbito da Administração Pública os problemas observados na presente auditoria nas três etapas de controle das transferências voluntárias de recursos públicos federais (exame e aprovação das propostas, acompanhamento concomitante da execução e análise da prestação de contas)". Cf. Min. Relator: Augusto Sherman Cavalcanti. DOU 17/07/09. p. 54. Disponível em: <http//:www.tcu.gov.br>. Acesso em: 29/07/2009.

${ }^{498}$ Em outras palavras: “[...] os serviços sociais [...] estão livres ao desempenho pelos particulares sem
} 
Sob a ótica desta dissertação, tais formas são instrumentos de controle por parte do Estado - com destaque para a contratualização do controle nas parcerias -, passíveis de fiscalização pelo TCU. Por este motivo, justifica-se a subdivisão de cada etapa de fiscalização em convênio, contrato de repasse, termo de parceria e contrato de gestão.

O TCU é explícito. Todas as fases dos convênios - e, a nosso ver, dos demais instrumentos de parceria - podem ser objeto de sua fiscalização, quais sejam: celebração, formalização, execução e prestação de contas ${ }^{499}$. A sua análise envolve, outrossim, o atendimento às exigências legais; execução financeira; execução física (obras, serviços e aquisição de bens); fidelidade e veracidade de documentos e procedimentos; os processos licitatórios ${ }^{500}$; a existência das empresas contratadas, além da avaliação da efetividade do instrumento ${ }^{501}$.

O TCU fiscaliza (ou assim deveria fazê-lo) a aplicação de recursos transferidos sob as modalidades de subvenção, auxílio e contribuição em todas as etapas da transferência: concessão, utilização e prestação de $\operatorname{contas}^{502}$.

Os principais temas examinados pelo TCU nos últimos anos, por ordem de quantidade de objeto em jurisprudência, são: (i) atividades de controle e execução dos instrumentos de parceria $^{503}$; (ii) recursos humanos ${ }^{504}$; (iii) licitações e ajustes administrativos ${ }^{505}$ e (iv)

necessidade de prévia delegação. Entretanto, o Poder Público não abandona a vigilância destas iniciativas condicionadas à estrita tutela do interesse coletivo. Daí a autorização, a regulamentação e a fiscalização destas entidades de natureza social pelo Poder Público". Cf. Luis Eduardo Patrone Regules. Terceiro Setor: Regime Jurídico das OSCIPs. São Paulo: Método, 2006. p. 127.

${ }^{499}$ É este o entendimento também da doutrina: “[...] o controle externo realizado pelo Tribunal de Contas não se restringe ao termo de parceria, mas abarca também o ato de qualificação da entidade como OSCIP, especialmente em razão da 'renúncia de receita' que a outorga deste título proporciona [...]". Cf. Luis Eduardo Patrone Regules. Terceiro Setor: Regime Jurídico das OSCIPs. São Paulo: Método, 2006. p. 171.

${ }^{500}$ A questão da necessidade ou não de realização de licitação pelas entidades em comento é controversa na doutrina e será examinada adiante. Dentre os argumentos desfavoráveis à sua exigência, segundo Sílvio Freire de Moraes, está que "mesmo a maioria dos autores que defendem a aplicação, com temperamentos, do art. 116 do mencionado diploma legal, em função da expressão no que couber, entende desnecessário o procedimento licitatório" (Controle externo: estudos e casos concretos. Belo Horizonte: Fórum, 2005. p. 85). Se de um lado o Tribunal de Contas da União algumas vezes a considera necessária, inclusive para seleção de OSCIPs (BRASIL. TCU, Acórdão n. 1777-43/05-Plenário. DOU 22. Nov. 2005. Min. Rel. Marcos Vinicius Vilaça.), o Tribunal de Contas do Estado de São Paulo segue em sentido contrário, ainda que ressalte a necessidade de garantia à transparência da escolha da entidade. Cf. BRASIL. TCE-SP. Manual básico: repasses públicos ao Terceiro setor, 2007.

${ }^{501}$ BRASIL. TCU, Convênios e Outros Repasses, 2008, p. 60.

${ }^{502}$ Francisco Eduardo Carrilho Chaves. Controle externo da gestão pública: a fiscalização pelo legislativo e pelos Tribunais de contas: teoria e jurisprudência. (cit.), 2007. p. 273.

${ }^{503}$ BRASIL. TCU. Decisão 592/1998; Decisão 931/1999; Acórdão 2261/2005-Plenário; Acórdão 2066/2006Plenário; Acórdão 705/2007-Plenário; Acórdão 2619/2007-Plenário; Acórdão 1331/2008-Plenário. "Nos acórdãos e decisões em comento, o TCU discutiu o seu próprio papel e delimitou as suas competências para o acompanhamento das parcerias entre as entidades privadas do terceiro setor e a administração pública; examinou e definiu sua competência para análise dos ajustes administrativos realizados entre os demais entes federativos e as entidades privadas; realizou auditorias em OSs, ONGs e OSCIPs; respondeu a denúncias realizadas sobre as parcerias e realizou seu papel de órgão auxiliar do Poder Legislativo, preparando estudos e 
atividades de fomento $^{506}$. A abordagem não esgotará o elenco de objetos passíveis de controle pelas Cortes de Contas, tendo-se procurado exemplificar, segundo a legislação pertinente, o que poderia - e muitas vezes tem sido - escopo de exame em relação a cada momento e instrumento de parceria.

A estrutura deste tópico foi inspirada nas dissertações de Natasha Schmitt Caccia Salinas e de Valéria Maria Trezza.

\subsubsection{Controle prévio}

Após a Constituição de $1967^{507}$, não há no Brasil previsão legislativa de atuação dos Tribunais de Contas, de modo prévio ou concomitante, como requisito de validade de ato

levantamentos de dados sobre o tema para a CPMI das ONGs". (DIAS, Maria Tereza Fonseca. O exercício do papel regulador do Tribunal de Contas da União sobre as parcerias da Administração pública com as entidades do Terceiro setor na execução de Políticas públicas. In: CONGRESSO NACIONAL DO CONPEDI, 17., Brasília, DF, 2008. Anais eletrônicos. Brasília, DF, 2008b. p. 3462).

504 BRASIL. TCU. Decisão 649/2002; Acórdão 2578/2004-Primeira Câmara; Acórdão 1840/2005; Acórdão 2101/2005-Segunda Câmara; Acórdão 1836/2007. “Quanto ao tema dos recursos humanos envolvidos na relação de parceria entre Administração Pública e terceiro setor, as principais questões que se apresentam dizem respeito à necessidade de realização de seleção para escolha daqueles que irão trabalhar nas entidades privadas sem fins lucrativos que receberem transferências de recursos da União e da possibilidade de remuneração de dirigentes dessas entidades com esses recursos. Poucas decisões, entretanto, enfrentaram tais questões. A maioria dos julgados discutiu o problema da contratação de agentes comunitários de saúde e agentes de combate às endemias, pelos entes federativos, por intermédio de entidades do terceiro setor". Maria Tereza Fonseca Dias. O exercício do papel regulador do Tribunal de Contas da União sobre as parcerias da Administração pública com as entidades do Terceiro setor na execução de Políticas públicas. In: CONGRESSO NACIONAL DO CONPEDI, 17. Brasília, DF, 2008. Anais eletrônicos. Brasília, DF, 2008b. p. 3472.

505 BRASIL. TCU. Acórdão 421/2004; Acórdão 1777/2005; Acórdão 601/2007- Primeira Câmara; Acórdão 1305/2007; Acórdão 2680/2007-Plenário; Acórdão 141/2008-Segunda Câmara; Acórdão 1331/2008. "A discussão sobre a aplicação do regime jurídico das licitações públicas em face das entidades do terceiro setor que irão atuar em parceria com a administração pública comporta três ordens distintas de questionamentos: 1) a dispensa de licitação prevista no inciso XXIV, do art. 24, da Lei n ${ }^{\circ} 8.666 / 93$, com redação dada pelo art. $1^{\circ}$, da Lei $n^{\circ} 9.648 / 98$, que autoriza a celebração de contratos de prestação de serviços com organizações sociais, sem licitação; 2) a necessidade de licitação para a escolha das OSCIPs e demais entidades que irão firmar termos de parceria e convênios com a administração pública; 3) a obrigatoriedade das entidades privadas que firmarem ajustes com a administração pública aplicarem em suas contratações, a Lei Geral de Licitações (Lei $\mathrm{n}^{\circ}$ 8.666/93), considerando-se a natureza pública dos recursos que recebem do Estado". Maria Tereza Fonseca Dias. O exercício do papel regulador do Tribunal de Contas da União sobre as parcerias da Administração pública com as entidades do Terceiro setor na execução de Políticas públicas. In: CONGRESSO NACIONAL DO CONPEDI, 17, Brasília, DF, 2008. Anais eletrônicos. Brasília, DF, 2008b. p. 3467).

${ }^{506}$ Maria Tereza Fonseca Dias. O Exercício do Papel Regulador do Tribunal de Contas da União sobre as Parcerias da Administração Pública com as Entidades do Terceiro Setor na Execução de Políticas Públicas (cit.), 2008b. p. 3456-3486.

507 “Até o advento da Constituição de 1967, o controle prévio correspondeu ao núcleo do sistema de fiscalização dos atos e contratos administrativos, exercido pelo Tribunal de Contas”. Cf. Antonio Silvio Magalhães Júnior. O Controle Externo da Administração Pública pelo Tribunal de Contas. Tese (Doutorado em Direito do Estado) - Faculdade de Direito, Universidade de São Paulo, São Paulo, 2005. p. 12. 
administrativo $^{508}$. Todavia faz-se possível, conforme o Enunciado n. 78 da Súmula de Jurisprudência do TCU:

[...] Não compete ao Tribunal de Contas da União julgar ou aprovar previamente contratos, convênios, acordos ou ajustes celebrados pela Administração Pública. Pode, todavia, o Tribunal, no exercício da auditoria financeira e orçamentária e com vistas ao julgamento das contas de responsáveis ou entidades sob sua jurisdição, tomar conhecimento dos respectivos termos, para, se verificar ilegalidade ou irregularidade, adotar providências no sentido de saná-las ou evitar sua reincidência.

O controle poderá se dar antes da realização de ato ou no curso do procedimento administrativo para sua prática $^{509}$, por exemplo, durante certificação, qualificação, realização de certame $^{510}$, concurso público ${ }^{511}$, chamamento público ou seleção de projetos e a própria celebração do instrumento.

Ao examinar as atribuições constitucionais e o momento de seu exercício, Pedro Roberto Decomain adota entendimento de que as auditorias de iniciativa do TCU podem se enquadrar como espécie de controle prévio a ato administrativo. O mesmo se aplica aos casos de determinação aos responsáveis de tomada de providências para correção de irregularidades existentes e para sustação dos efeitos dos atos viciados, quando as providências ordenadas não tiverem sido tomadas (art. 71, IX e X da CF/88) ${ }^{512}$. Mediante as citadas auditorias, lembra o autor - e outros procedimentos, os Tribunais de Contas poderão verificar a atividade da Administração Pública ou de particulares gestores de recursos públicos, pela perspectiva da legalidade, legitimidade, economicidade, sendo amplo o seu poder de controle prévio ou concomitante ${ }^{513}$.

As disciplinas jurídicas das OSs e OSCIPs não descartam o controle prévio ${ }^{514}$. Optaram, todavia, pela preponderância de um "controle de resultados, em detrimento do controle por processos, clássico do modelo da administração burocrática",515 - sem escapar do controle formal ${ }^{516}$.

\footnotetext{
${ }^{508}$ Pedro Roberto Decomain. Tribunais de Contas no Brasil. (cit.), 2006. p. 179

${ }^{509}$ Pedro Roberto Decomain. Tribunais de Contas no Brasil. (cit.), 2006. p. 179.

${ }^{510}$ Por força do art. 113, § 2 da Lei Federal n. 8.666/93.

${ }^{511}$ Pedro Roberto Decomain. Tribunais de Contas no Brasil. (cit.), 2006. p. 186.

${ }^{512}$ Note-se que, para Evandro Martins Guerra, os incisos IX e X configuram-se espécie de controle concomitante (cf. Os controles externo e interno da Administração pública. [cit.], 2005. p. 209).

${ }^{513}$ Pedro Roberto Decomain. Tribunais de Contas no Brasil. (cit.), 2006. p. 187.

514 Lei $9.637 / 98$, art. 7 e art. 9.790/99, art. $10, \S 2$.

${ }^{515}$ Vanice Lírio Valle. Terceiro Setor e parcerias com a Administração Pública: desafios ao controle das OS e OSCIPs. Revista de Direito do Terceiro Setor, Belo Horizonte, ano 2, n. 4, jul./dez. 2008. p. 57.

${ }^{516}$ Para Francisco de Assis Alves, em que pese o controle das organizações sociais estar previsto como processo
} 
Suavizado sob alguns aspectos neste contexto, o controle prévio em relação às entidades em comento há de ser exercido rotineiramente pelo controle interno ou por órgãos públicos parceiros, e não pelos Tribunais de Contas, mas estes atuarão de forma mais seletiva e por amostragem, baseados na identificação de áreas de risco ${ }^{517}$. No entanto, parece-nos não estarem impedidos de assim o fazer, sendo de grande valia diante das malversações por eles mesmos aferidas - na maior parte das vezes, tardiamente.

Em casos de parcerias, o controle prévio por estas Cortes incidirá muito mais sobre o órgão público do que sobre a entidade privada a qual, nesta etapa, ainda não efetua a gestão de recursos públicos.

O Anteprojeto de Lei Orgânica da Administração Pública não adota este entendimento, sendo explícito em estabelecer como diretriz geral a supressão dos controles meramente formais ou cujo valor seja superior ao risco, pelo fortalecimento do controle a posteriori e predomínio da verificação de resultados, simplificação dos procedimentos, responsabilização pessoal e erradicação da sobreposição de competências. Como amplitude do controle, prevê sua incidência sobre a aplicação de recursos ou bens públicos, resultados e legalidade.

Passamos ao exame dos objetos passíveis de controle na etapa prévia à celebração das parcerias - convênios e contratos de repasse, termos de parceria e contratos de gestão. Nesta oportunidade, será aprofundado o exame quanto às características destes instrumentos.

Justifica-se o tratamento em conjunto dos convênios e contratos de repasse por ser a legislação quase idêntica ${ }^{518}$, destacando-se as diferenças quando necessário.

\section{a) Convênio e contrato de repasse}

O controle prévio incidirá quando a entidade do terceiro setor submeter seu plano de trabalho a apreciação pelo órgão gestor de recursos de determinado programa. Há diversas regras aplicáveis nesta fase que obrigam a administração pública e as referidas entidades a observarem uma série de requisitos ${ }^{519}$.

\footnotetext{
inovador, dificilmente escapariam das regras impostas ao uso de recursos públicos. Cf. Fundações, organizações sociais, agências executivas, organizações da sociedade de interesse público e outras modalidades de prestação de serviço público. São Paulo: LTr, 2000. p. 188-189.

${ }^{517}$ Mario Mora Quirós. Responsabilização pelo controle de resultados. (cit.), 2006. p. 181.

518 “Observa-se que o contrato de repasse é muito semelhante ao convênio. A grande diferença entre os dois reside em que, no contrato de repasse, existe a intermediação realizada por instituição ou agente financeiro público federal, atuando como mandatário da União". Cf. Guilherme Henrique de La Rocque Almeida. Controle das transferências financeiras da União. (cit.), 2008b. p. 261.

${ }^{519}$ Natasha Schmitt Caccia Salinas. Avaliação legislativa no Brasil: um estudo de caso sobre as normas de controle
} 
A Instrução Normativa n. 01/97, elaborada sob forte influência do TCU, disciplinou os convênios financeiros e os contratos de repasse até a publicação da Portaria Interministerial n. $127 / 2008$ e suas alterações. ${ }^{520}$ Por esta razão, entendemos conveniente versar em especial sobre as regras e condições previstas nesta Portaria e orientações do "Manual de Convênios e Outros Repasses" do TCU, mencionando a IN n. 01/97, se pertinente ${ }^{521}$. Além da observância desta Instrução e Portaria, o TCU tem exigido dos órgãos públicos parceiros a edição de regulamento interno sobre a celebração de parcerias e seu controle ${ }^{522}$.

Segundo a Portaria, a União não é obrigada a celebrar convênios e contratos de repasse $\left(\operatorname{art} .1^{\circ}, \S 4^{\circ}\right)$, mas se o fizer, deverá ser com entidades públicas ou privadas sem fins lucrativos detentoras de capacidade técnica e para execução de objetos relacionados às suas atividades estatutárias ${ }^{523}\left(\operatorname{art.} 1^{\circ}, \S 2^{\circ}\right)$.

Não se aplicam as exigências da PI n. 127/2008 aos instrumentos elencados no seu art. $2^{\circ}$, como o contrato de gestão (inciso III) e outros instrumentos congêneres (IV). É vedada, ademais, a celebração de convênios e contratos de repasse, se a entidade estiver em mora ou inadimplente junto ao Poder Público ${ }^{524}$, visar fins lucrativos ou não dispuser de condições técnicas ${ }^{525}\left(\operatorname{art.} 6^{\circ}\right)$.

A PI n. 127/08, com a redação da Portaria Interministerial 342/08, estabeleceu a

das transferências voluntárias de recursos públicos para entidades do terceiro setor. (cit.), 2008. p. 110.

${ }^{520}$ De acordo com o art. 74B da PI n. 127/08, a IN n. 01/97 não se aplica aos convênios celebrados sob a vigência daquela. $\mathrm{O}$ art. 68 da citada Portaria estabeleceu que após 31 de dezembro de 2008 os convênios e contratos de repasse firmados até 29 de maio de 2008 que estivessem vigentes deveriam ser extintos ou registrados no SICONV, salvo se objeto de tomada de contas especial.

${ }^{521}$ O TCU ainda não teve oportunidade de verificar reiteradamente a observância da Portaria Interministerial n. 127/08 pelos órgãos públicos. No entanto, tem citado-a em seus recentes julgados. Por exemplo, ao criticar a ausência de chamamento público para seleção de projetos, o TCU transcreveu conteúdo da citada Portaria para indicar o modo como deveria comportar-se o órgão auditado. Também citou e transcreveu conteúdo da citada Portaria quanto à relação entre a liberação de recursos e o acompanhamento da execução dos convênios. Cf. no Acórdão n. 1562/2009 - Plenário. Min. Relator: Augusto Sherman Cavalcanti. DOU 17/07/09 Disponível em: $<$ http//:www.tcu.gov.br>. Acesso em: 29/07/2009.

${ }^{522}$ Cf. Acórdão n. 1562/2009 - Plenário. Min. Relator: Augusto Sherman Cavalcanti. DOU 17/07/09 Disponível em: <http//:www.tcu.gov.br>. Acesso em: 29/07/2009

${ }^{523}$ O TCU já decidiu no sentido de determinar a órgãos públicos "que se abstenham de realizar transferências voluntárias a organizações não governamentais (ONGs) e a organizações da sociedade civil de interesse público (OSCIPs) que não contemplem em seus estatutos as atividades dos objetivos pretendidos pelo ajuste;" - Acórdão 1403/2008 - Plenário.

${ }^{524}$ A vedação nem sempre é observada, como verificado no Acórdão n. 402/2009 relativo à auditoria na qual se identificou "a utilização de municípios como intermediários para assinar convênios com ONG inadimplente com a União”. (pp. 17 e 89).

${ }^{525}$ Neste sentido, o TCU já decidiu que "3.45. Cabe à Funasa analisar a capacidade do proponente para celebrar o convênio, bem como o cumprimento dos pré-requisitos. Vale lembrar que a falta de adequado controle preventivo por parte de órgão repassador de recursos federais por meio de transferências voluntárias poderá ensejar a responsabilização dos gestores e responsáveis (...).” Acórdão n. 2067/2008 - Plenário. 
obrigatoriedade de inserção no Sistema de Gestão de Convênios e Contratos de Repasse SICONV, por meio do Portal dos Convênios (art. $3^{\circ}$ ) dos atos e os procedimentos relativos a formalização, execução, acompanhamento, prestação de contas e informações acerca das tomadas de contas especiais (TCE) dos convênios e contratos de repasse. Por esta razão, como condição prévia para apresentar proposta de trabalho, o interessado deverá se credenciar no SICONV (art. 12) $)^{526}$.

Também será disponibilizada anualmente naquele site a relação dos programas a serem executados e, se couberem, os critérios de seleção do convenente ou contratado, de modo a aferir, dentre outros, a qualificação técnica e a capacidade operacional ${ }^{527}$ destes (art. $4^{\circ}$ ).

Para celebração de convênio ou contrato de repasse, na Portaria não se exige qualquer titulação, havendo, porém, restrição quanto ao fim da entidade, que não poderá ser de interesse mútuo - clubes, associações de servidores ou quaisquer entidades congêneres, excetuadas creches e escolas para o atendimento pré-escolar (inciso VIII, art. 39).

Todavia, para cadastramento anual em órgão da administração ou nas unidades cadastradoras do Sistema de Cadastramento de Fornecedores - SICAF, com vistas à celebração dos instrumentos em exame (art. 17) - outra exigência além do credenciamento no SICONV -, a entidade que não tiver ações voltadas para educação, assistência social e saúde, deverá apresentar CNPJ com, no mínimo, três anos e comprovação de qualificação técnica e capacidade operacional, mediante declaração de funcionamento regular nos três anos anteriores ao credenciamento, emitida por três autoridades do local de sua sede (art. 18). Para as exceções citadas, os prazos foram reduzidos ao exercício anterior.

Aqui cabe breve digressão. Com a Portaria, retornou-se a exigência semelhante ao título de utilidade pública, superada com o termo de parceria. A despeito de o intuito ser evitar a criação de entidade sem fins lucrativos para celebração imediata de convênio e a aferição de sua real existência e funcionamento, ao exigir para fins de cadastro a criação de ONG nos três anos anteriores e a emissão de declarações por autoridades locais a seu respeito, submete-se ela a manter relacionamentos de ordem política, deturpando a lógica objetiva visada pelos

\footnotetext{
526 Observa-se que Decreto $n^{\circ}$ 6.428/2008 estabeleceu que, antes da celebração de convênio - e não da apresentação de proposta de trabalho -, a entidade deverá obter prévio cadastro no SICONV, conforme normas do órgão central do sistema.

${ }^{527}$ O Decreto-lei n. 200/67 já previa em seu art. 10 que o convênio - então somente celebrado entre entes da federação - poderia ser celebrado desde que os partícipes estivessem devidamente aparelhados - o que ainda nem sempre é atendido, como se extrai de excerto de decisão do TCU: "No tocante à execução das atividades finalísticas da Fundação, notadamente aquelas voltadas à saúde dos povos indígenas, foram identificadas deficiências na aplicação dos critérios de seleção das ONGs, as quais, em muitos casos, revelaram não deter estrutura para consecução dos objetivos pactuados." Cf. Relatório de Auditoria de Conformidade objeto do Acórdão TCU n. 2697/2008 - Plenário, Ministro Relator Valmir Campelo.
} 
termos de parceria. Esta observação é importante, pois as OSCIPs celebram muito mais convênios do que termos de parceria, segundo Natasha Schmitt Caccia Salinas, abdicando o governo de dar continuidade ao sistema criado sob a ótica da Administração Consensual, para retroceder àquele da década de 30 do século passado, relativo ao título de utilidade pública que não garantiu a boa gestão dos recursos públicos.

Por força do Decreto $n^{0}$ 6.619/2008 e do art. $6^{\circ}$, inciso II da PI n. 127/2008 é vedada, ainda, a celebração de convênio com entidades privadas sem fins lucrativos cujo dirigente seja agente político de Poder ou do Ministério Público, dirigente de órgão ou entidade da administração pública de qualquer esfera governamental, ou respectivo cônjuge ou companheiro, ou parente em linha reta, colateral ou por afinidade até o segundo grau.

Somando-se às citadas exigências, têm-se verificado nas $\operatorname{LDOs}^{528}$ alguns requisitos como titulações e desenvolvimento de dadas atividades pelas entidades privadas para fins de recebimento, de subvenção social, contribuição e auxílio, requisitos estes objeto de aferição pelas Cortes de $\operatorname{Contas}^{529}$ e alterações anuais.

Incidirá controle, ademais, nos documentos apresentados pela entidade para cadastramento (art. 24, § 7) como condição para celebrar convênio ou contrato de repasse (arts. 24 e 25): (i) comprovação de regularidade tributária e fiscal junto à Fazenda Pública federal; (ii) inexistência de pendências pecuniárias registradas no $\mathrm{CADIN}^{530}$; (iii) comprovação de regularidade quanto ao depósito das parcelas do FGTS; (iv) inexistência de pendências ou irregularidades nas prestações de contas no SIAFI e no SICONV de recursos anteriormente recebidos da União; (v) cadastro atualizado no SICONV; (vi) Plano de Trabalho aprovado; (vii) licença ambiental se for o caso, dentre outros. A Portaria em comento flexibilizou a exigibilidade dos citados documentos, ao não condicionar a celebração do

\footnotetext{
${ }^{528}$ A título de exemplo, quanto às subvenções sociais, a LDO de 2009 (Lei 22.768/08) assim dispôs: “Art. 32. É vedada a destinação de recursos a título de subvenções sociais para entidades privadas, ressalvadas aquelas sem fins lucrativos, que exerçam atividades de natureza continuada nas áreas de cultura, assistência social, saúde e educação, observado o disposto no art. 16 da Lei no 4.320 , de 1964, e que preencham uma das seguintes condições: I - sejam de atendimento direto ao público, de forma gratuita, e estejam registradas no Conselho Nacional de Assistência Social - CNAS; II - sejam formalmente vinculadas a organismo internacional do qual o Brasil participe, tenham natureza filantrópica ou assistencial e estejam registradas nos termos do inciso I do caput deste artigo; III - atendam ao disposto no art. 204 da Constituição, no art. 61 do ADCT, bem como na Lei no 8.742, de 7 de dezembro de 1993; IV - sejam qualificadas como Organização da Sociedade Civil de Interesse Público - OSCIP, com termo de parceria firmado com o Poder Público Federal, de acordo com a Lei no 9.790, de 23 de março de 1999".

${ }^{529}$ Dentre outros exemplos, no Acórdão n. 1232/2008 - Plenário - decorrente de representação para apurar irregularidades em convênios e contratos de repasse celebrados nos anos de 2005 e 2006, o TCU verificou a violação a vedações da LDO, como reforma em imóvel das entidades privadas com recursos públicos, celebração de contrato de repasse com entidade com menos de três anos de criação e transferências de recursos a entidades com atribuições estatutárias diversas dos objetos daqueles instrumentos.
}

${ }^{530}$ A Lei Federal n. 10.522/02 versou sobre o CADIN. 
instrumento de parceria a sua apresentação tempestiva, sob condição resolutiva (art. 27).

Após obter o credenciamento, o proponente poderá apresentar Proposta de Trabalho no SICONV, em conformidade com os programas e diretrizes estabelecidos. Deverá descrever o objeto, a justificativa e a demonstração de interesses recíprocos, a estimativa de recursos financeiros e a contrapartida - que restou facultativa (art. 20, PI n. 127/08), a previsão de prazo para execução e informações sobre sua capacidade técnica e gerencial (art. 15), devendo o órgão competente analisá-la, aceitá-la ou rejeitá-la, observando os termos do art. 16 da Portaria.

Tanto o Decreto Federal n. 6.170/07 (art. $4^{\circ}$ ) quanto a PI n. 127/08 estabeleceram a faculdade de realização de chamamento público visando à seleção de projetos. Caso efetivado, há de se observar as regras do art. $5^{\circ}$ da Portaria, com destaque para a inovação constante do $\S 2^{\circ}$, no sentido de dever ser aferida a qualificação técnica, capacidade operacional das entidades privadas sem fins lucrativos, segundo critérios técnicos e objetivos a serem definidos, bem como por meio de indicadores de eficiência e eficácia a serem utilizados a partir de 2011, estabelecidos com base no histórico de desempenho na gestão de convênios ou contratos de repasse celebrados a partir de 1 de julho de 2008 .

Houve, assim, progresso na contenção da discricionariedade da Administração, objeto de crítica à IN STN n. 01/97, que não oferecia limites a ela para seleção da entidade privada e sua capacidade técnica e operacional.

Depois de obter o credenciamento, o cadastro e apresentar e ter aprovada a Proposta de Trabalho no SICONV, a entidade poderá apresentar Plano de Trabalho ${ }^{531}$ para ser avaliado pelo órgão ou entidade repassadora de recursos quanto a viabilidade e adequação aos objetivos de programa, devendo conter, no mínimo, (i) justificativa para celebração do ajuste, (ii) descrição do objeto, (iii) metas $^{532}$, (iv) etapas, (v) cronograma de execução e de desembolso e (vi) plano para aplicação de recursos e contrapartida, se for o caso (art. 21).

\footnotetext{
${ }^{531}$ O TCU identificou e criticou vários planos de trabalho, motivo pelo qual passou a determinar o modo como deveria ser apresentado. Neste sentido, vide o Acórdão Plenário n. 544/2008: “9.2.2.2. em cumprimento do disposto no art. $2^{\circ}, \S 1^{\circ}$, da IN STN n ${ }^{\circ} 01 / 97$ c/c os arts. $7^{\circ}, 14$ e 55, inciso I, da Lei $n^{\circ} 8.666 / 93$, exija que o Plano de Trabalho dos convênios a serem celebrados contenha a especificação completa do bem a ser produzido ou adquirido e, no caso de obras, instalações ou serviços, o projeto básico, entendido como tal o conjunto de elementos necessários e suficientes para caracterizar, de modo preciso, a obra, instalação ou serviço objeto do convênio, sua viabilidade técnica, custos, fases, ou etapas, e prazos de execução, devendo conter os elementos discriminados no inciso IX do art. $6^{\circ}$ da Lei ${ }^{\circ} 8.666 / 93$ ”. Também neste sentido, conferir o Acórdão TCU n. 1331/08, no qual desempenhou nítido papel orientativo.

${ }^{532}$ Ainda que o convênio não seja conhecido como o instrumento por excelência com foco no resultado, cada vez mais a legislação e o TCU têm exigido dos órgãos parceiros a sua previsão. Neste sentido, o TCU determinou que: "9.4.3. ao celebrar convênios ou instrumentos similares, observe rigorosamente as disposições legais pertinentes quanto à correta e suficiente descrição e detalhamento das metas, etapas/fases a serem executadas, em seus aspectos quantitativos e qualitativos". Cf. Relatório de Auditoria de Conformidade objeto do Acórdão TCU n. 2697/2008 - Plenário, Ministro Relator Valmir Campelo.
} 
A contrapartida ${ }^{533}$ a ser ofertada pelo proponente, quando couber, deverá ser prevista no convênio, nas porcentagens estabelecidas pela LDO e em consonância com as decisões do $\mathrm{TCU}^{534}$. Se não ofertada ou não aplicada até o final do convênio, implicará restituição à União ou imputação de débito ao gestor omisso, ensejando a instauração de TCE ${ }^{535}$. A LDO de 2009 - reiterada no Projeto de Lei da LDO 2010 - todavia, excepcionou as entidades de assistência social e saúde registradas no Conselho Nacional da Assistência Social - CNAS acerca da exigência de contrapartida.

Quanto ao Plano de Trabalho, não se estabeleceu parâmetros legais precisos para avaliação da adequação de cada um dos seus itens pela administração pública, prejudicando o seu controle e a própria avaliação dos resultados dos projetos executados.

A critério do órgão público, o projeto básico ou o termo de referência ${ }^{536}$ poderá ser objeto de exigência antes ou depois da celebração do convênio ou do contrato de repasse (art. 23), condicionada a extinção destes em caso de rejeição. Como avanço, previu-se a possibilidade de as entidades receberem recursos específicos para elaboração destes documentos (art. 23, $\S 6^{\circ}$ ).

No tocante ao teor e às cláusulas obrigatórias dos instrumentos em exame (art. 30) objeto de possível aferição pelo TCU, destacam-se: (i) objeto em consonância com o Plano de Trabalho; (ii) obrigações recíprocas; (iii) contrapartida, quando couber; (iv) vigência e metas a serem atingidas; (v) cronograma de desembolso; (vi) obrigação de atualização das informações no SICONV; (vii) restituição de recursos; (viii) obrigação de movimentação em conta bancária específica em instituição financeira controlada pela União ${ }^{537}$; (ix) a forma como o concedente ou contratante acompanhará a execução física de seu objeto; (xii) a faculdade de rescisão a qualquer tempo; (xiii) a obrigação de prestar contas e seu prazo; (ix) a

\footnotetext{
533 Não se considera contraprestação, salvo raras exceções, as despesas ordinárias de custeio do partícipe. Cf. Ubiratan Aguiar et al. Convênios e tomadas de contas especiais: manual prático. 2. ed. Belo Horizonte: Fórum, 2007. p. 30.

${ }^{534}$ No Acórdão n. 1.936/2003 - Plenário, o TCU recomendou que fosse alterada a IN n. 01/97 para fazer constar a exigência de manutenção da contrapartida de conta bancária específica. Conferir o Acórdão n. 2.261/2005Plenário, Ministro Relator: Guilherme Palmeira. Assunto: Relatório de Auditoria.

${ }^{535}$ Ubiratan Aguiar et al. Convênios e tomadas de contas especiais: manual prático. (cit.), 2007. p. 27.

536 “Quando o objeto do convênio, do contrato de repasse ou do termo de cooperação envolver aquisição de bens ou prestação de serviços, o projeto básico recebe o nome de Termo de Referência, o que não altera a necessidade de o documento contemplar a descrição do bem ou serviço, o orçamento detalhado, a definição dos métodos e o prazo de execução do objeto”. BRASIL. TCU, Convênios e Outros Repasses, 2008.

${ }^{537}$ A conta bancária deve ser específica para cada convênio e configura-se exigência de significativa importância para os órgãos de controle, devendo haver comprovação documental (faturas, recibos, notas fiscais ou outros) da destinação dos recursos, para fins de nexo de causalidade e movimentação mediante cheque nominal ou ordem bancária. Cf. Ubiratan Aguiar et al. Convênios e tomadas de contas especiais: manual prático. (cit.), 2007. p.38-41.
} 
sujeição às normas do Decreto n. 6.170/07 e Decreto n. 93.872. Também deverá restar estipulado o destino dos bens remanescentes do convênio ou contrato de repasse, considerados como tais os adquiridos por meio destes sem incorporação ao objeto de sua celebração (art. 28).

O TCU aponta como frequentes as seguintes irregularidades e falhas na fase de proposição dos convênios: (i) plano de trabalho pouco detalhado; (ii) metas quantitativas e qualitativas insuficientemente descritas; (iii) caracterização insuficiente da situação de carência dos recursos; (iv) projeto básico incompleto e/ou com informações insuficientes; (v) ausência de projeto básico; (vi) falta de comprovação da existência de contrapartida (orçamentária e financeira); e (vii) orçamento subestimado ou superestimado ${ }^{538}$.

A legislação aplicável prevê, outrossim, algumas limitações à utilização dos recursos públicos, não podendo constar do convênio (ar. $8^{\circ}$ da IN STN n. 01/97 e art. 39 da PI n. 127/08), por exemplo, o pagamento de taxa de administração ${ }^{539}$ - salvo pagamento de despesas administrativas até $15 \%$ do valor do objeto, previstas no instrumento e no plano de trabalho (art. 39, parágrafo único, PI n. 127/08); realização de despesas com taxa bancária; despesas com publicidade ${ }^{540}$ salvo as permitidas em lei; e prestação de serviços de consultoria ou assistência por servidor ou empregado público.

Especificamente sobre o controle prévio dos contratos de repasse, o art. 30 da PI n. 127/08 previu como cláusulas necessárias dos instrumentos por ela regulados, além daquelas já acima elencadas, duas referentes especificamente ao contrato de repasse: (i) a forma de liberação dos recursos ou desbloqueio e (ii) o bloqueio de recursos na conta corrente vinculada. O TCU poderá verificar o atendimento a estes requisitos.

\section{b) Termo de Parceria}

O termo de parceria, já se disse, foi criado como alternativa e aprimoramento do marco

\footnotetext{
${ }^{538}$ BRASIL. TCU. Convênios e Outros Repasses., 2008, p. 35.

${ }^{539}$ Neste sentido, o TCU assim decidiu no Acórdão n.1684/2007 - Segunda Câmara: “[...] foi constatado que, de fato, a remuneração percebida pelo recorrente decorreu do exercício do cargo de Presidente da entidade, atividade de natureza tipicamente administrativa, gerencial, de sociedade civil não governamental sem fins lucrativos. Desse modo, em face da ilegalidade da relação de trabalho alegadamente estabelecida e da remuneração percebida, não há que se falar em enriquecimento ilícito do Estado. Outrossim, convém registrar que o motivo determinante para a instauração da Tomada de Contas Especial em questão foi a realização de pagamentos indevidos com os recursos do convênio e não o descumprimento do objeto conveniado, como crê o recorrente".

${ }^{540}$ Evita-se, assim, a promoção publicitária do gestor, cujo ato é considerado grave e passível de multa pelo TCU. Cf. Ubiratan Aguiar et al. Convênios e tomadas de contas especiais: manual prático. (cit.), 2007. p. 51.
} 
legal do terceiro setor, no tocante a um grupo particular de entidades privadas dele integrantes.

Com esse instrumento, procurou-se disciplinar as transferências voluntárias de modo diverso, introduzindo maior flexibilidade na utilização de recursos públicos e correspondente criação de novos controles sobre essas entidades ${ }^{541}$.

Acerca dos instrumentos de controle prévio relativos aos termos de parceria, podem ser indicados os que se seguem, sem prejuízo de outros.

Como instrumento legal inicial de controle, há a qualificação de entidades como OSCIP, sem a qual não poderão celebrar termo de parceria. A Lei das OSCIPs estabeleceu procedimento simplificado para este reconhecimento e, obedecidos os requisitos legais, a qualificação será obrigatória, como ato vinculado do poder público.

Por parte da entidade, esta deverá possuir objeto social com as finalidades previstas no art. $3^{\circ}$ da citada Lei ${ }^{542}$, apresentar a documentação exigida e obedecer a determinado regime de funcionamento para a transparência e responsabilidade de seus atos. Ainda, para pleitear a qualificação, a entidade não necessitará ter mais de um ano de existência - e, portanto, atestar comprovação de capacidade operacional ${ }^{543}$ de longa data. Finalizado o primeiro exercício, porém, o parceiro público solicitará a apresentação de balanço patrimonial e declaração de isenção de imposto de renda (art. $3^{\circ}, \S 3^{\circ}$ do Decreto n. 3.100/99).

A PI n. 127/08, alterada pela Portaria Interministerial 342/08 estabeleceu que os atos e os procedimentos relativos à formalização, execução, acompanhamento, prestação de contas e informações acerca das TCE dos termos de parceria serão realizados por meio do SICONV. Em que pese a intenção seja dar maior transparência ao manejo de recursos públicos, não há

\footnotetext{
${ }^{541}$ Natasha Schmitt Caccia Salinas. Avaliação legislativa no Brasil: um estudo de caso sobre as normas de controle das transferências voluntárias de recursos públicos para entidades do terceiro setor. (cit.), 2008. p. 145.

542 “O art. $3^{\circ}$ da Lei no 9.790/99 define quais são as finalidades admitidas:

(i) promoção da assistência social;

(ii) promoção da cultura, defesa e conservação do patrimônio histórico e artístico;

(iii) promoção gratuita da educação;

(iv) promoção gratuita da saúde;

(v) promoção da segurança alimentar e nutricional;

(vi) defesa, preservação e conservação do meio ambiente e promoção do desenvolvimento sustentável;

(vii) promoção do voluntariado;

(viii) promoção do desenvolvimento econômico e social e combate à pobreza;

(ix) experimentação, não lucrativa, de novos modelos sócio-produtivos e de sistemas alternativos de produção, comércio, emprego e crédito;

(x) promoção de direitos estabelecidos, construção de novos direitos e assessoria jurídica gratuita de interesse suplementar;

(xi) promoção da ética, paz, cidadania, direitos humanos, democracia e outros valores universais;

(xii) estudos e pesquisas, desenvolvimento de tecnologias alternativas, produção e divulgação de informações e conhecimentos técnicos e científicos que digam respeito às atividades mencionadas neste artigo".

${ }^{543}$ Como se vê, o intuito não foi não enfatizar o controle prévio, mas a avaliação de resultados.
} 
dúvida de ter esta regulamentação - infralegal - interferido na flexibilização e controle dos resultados pretendidos em relação às OSCIPs.

Para o TCU, o Poder Executivo deve realizar seleção das OSCIPS para firmar termo de parceria - previsto no art. 23 do Decreto $n^{0} 3.100 / 99$ - em toda e qualquer situação. Também deve o Poder Público, antes da celebração do termo de parceria, levar em consideração, quando cabível, os requisitos listados no art. 27 do Decreto n. ${ }^{\circ}$ 3.100/99, entre outros necessários à aferição da capacidade operacional da entidade interessada ${ }^{544}$.

Apesar de muito debatida, a Lei Federal n. 8.666/93 não é aplicável às OSCIPs, devendo ter regulamento próprio para aquisição de bens e serviços ou, segundo o Decreto $n$. $5.504 / 05$, realizar certame, de preferência sob a modalidade pregão eletrônico ${ }^{545}$.

Questão controversa é a obrigatoriedade de seleção de projetos. Na Lei das OSCIPs, não há previsão de licitação ou processo seletivo quando da apresentação de projetos. $\mathrm{O}$ Decreto n. 3.100/99 estabeleceu diretrizes e a faculdade para a sua realização. Dentre os parâmetros, a Administração Pública deverá detalhar em especificação técnica o objeto pretendido com o termo de parceria (art. 24); deverão ser previstos os critérios de seleção e julgamento das propostas; e o valor máximo a ser desembolsado (art. 25). Serão levados em consideração na seleção e julgamento dos projetos, a adequação destes ao objeto do edital; a capacidade técnica e operacional dos candidatos ${ }^{546}$; a adequação entre os meios sugeridos, seus custos, cronogramas e resultados, a regularidade jurídica e institucional da OSCIP, entre outros documentos exigidos (art. 27).

No tocante à faculdade de realização de concurso de projeto, em 1999 o TCU recomendou a alteração da redação do Decreto n. 3.100/99 para passar a ser obrigatória quando os recursos repassados superassem determinados limites - a fim de evitar-se

\footnotetext{
${ }^{544}$ Maria Tereza Fonseca Dias. O Exercício do Papel Regulador do Tribunal de Contas da União sobre as Parcerias da Administração Pública com as Entidades do Terceiro Setor na Execução de Políticas Públicas. (cit.) p. 3468.

${ }^{545} \mathrm{O}$ TCU, no Acórdão n. 1.777/05 consignou que às OSCIPs e aos Termos de Parceria não se aplica a Lei Federal n. 8.666/93 ou o Decreto n. 5.504/05, porque na sua lei regedora não haveria disposição neste sentido.

${ }^{546}$ O TCU, em razão de representação, examinou a observância pelo Poder Público e OSCIP de todos os requisitos para celebração de termo de parceria, bem como sua execução. Nesta oportunidade, analisou minuciosamente, inclusive por meio de documentos, inspeção, diligência, oitiva de dirigentes e visita local, a compatibilidade do escopo da OSCIP com relação ao projeto executado, a demonstração de capacidade técnica para execução deste, tendo ao final aplicado o benefício da dúvida para acatar parcialmente as justificativas apresentadas, determinar recomendações e indicar monitoramento para aferir a observância destas. Verificou, ainda, as contratações realizadas sem observância dos princípios como publicidade, competição e menor preço. TCU. Acórdão n. 1386-2009 - Plenário. Min. Relator André Luís de Carvalho. p. 02. Disponível em: $<$ http//:www.tcu.gov.br>. Acesso em: 29/07/2009.
} 
procedimento burocratizado em casos sem necessidade ${ }^{547}$. Este posicionamento foi alterado em 2005, quando o TCU sugeriu a obrigatoriedade de realização de seleção de OSCIP para todo e qualquer caso ${ }^{548}$ - entendimento ainda não acatado.

Na prática, raros são os casos de seleção de projeto de OSCIPs para celebração de termo de parceria e muitas delas os celebram reiteradamente com os mesmos órgãos ${ }^{549}$. Em verdade, quando há seleção de projetos, dá-se para celebração de convênio, e não para termo de parceria. Destaca-se, ademais, haver somente para os casos de concurso a previsão de comprovação de capacidade técnica e operacional (art. 27, II da Lei das OSCIPs).

Nem mesmo os certames realizados pelo procedimento da Lei Federal n. 8.666/93, lembre-se, garantem de forma absoluta a imparcialidade na contratação. De todo modo, não se pode negar que a seleção pública dificulta a ação do administrador no sentido de privilegiar certa entidade ou contratar qualquer uma que se apresente.

Também o programa de trabalho pode ser considerado como instrumento de controle prévio. Este documento deverá estabelecer as metas e os resultados a serem atingidos, bem como o cronograma com prazos para execução do projeto; a previsão de receitas e despesas, inclusive quanto a pagamento de pessoal; os critérios de avaliação de desempenho e os indicadores de resultado das ações a serem realizadas. Os indicadores configuram-se ferramentas de avaliação em termos de eficiência, eficácia e efetividade dos projetos, e não de mero conhecimento do trabalho desenvolvido, como é o caso do relatório de execução físicofinanceira das prestações de contas dos convênios. Dependerão, ainda, da finalidade da parceria em cada caso concreto.

$\mathrm{Na}$ análise do termo de parceria propriamente dito, serão objeto de controle prévio a observância de cláusulas obrigatórias (art. 10 da Lei das OSCIPs): previsão de objeto; metas; cronograma; receitas e despesas; critérios objetivos de avaliação de desempenho; obrigação de apresentação de relatório de execução do objeto ao término de cada exercício, com

\footnotetext{
${ }^{547}$ Decisão TCU n. 931/99 - Plenário. Relator: Marcos Vinicios Vilaça.

${ }^{548}$ Acórdão TCU n. 1.777/2005- Plenário. Relator: Marcos Vinicios Vilaça, DOU, 22 nov. 2005. Valéria Maria Trezza concluiu em pesquisa realizada junto aos órgãos públicos parceiros que a utilização de concurso de projetos para seleção da OSCIP e celebração de Termo de Parceria varia, inclusive quanto à interpretação dada ao Acórdão n. 1777/05 do TCU:

(i) de obrigatório e com participação restrita a OSCIPs para alguns,

(ii) outros entendem obrigatório mas sem restrição a participação de entidades com este título,

(iii) bem como facultativo. Para a autora, a seleção poderá garantir a fundamentação dos atos administrativos, a objetividade dos critérios de escolha, a imparcialidade, a transparência e a seleção de entidade melhor capacitada para executar a ação.
}

Valéria Maria Trezza. O termo de parceria como instrumento de relação público/privado sem fins lucrativos: o difícil equilíbrio entre flexibilidade e controle. (cit.), 2007. p. 120.

${ }^{549}$ Ibid., 2007. p. 177. 
comparativo das metas e os resultados alcançados; obrigação de prestação de contas dos gastos e receitas realizados e, por fim, publicação na imprensa oficial de extrato simplificado do termo de parceria. Não há obrigação de devolução do saldo de recursos eventualmente não gastos em decorrência da eficiência de sua gestão e dispêndio.

Outros instrumentos legais regulam o termo de parceria. A título de exemplo, as LDOs para os exercícios de 2008, 2009 e $2010^{550}$ estabeleceram a exigência de contrapartida das OSCIPs, na mesma esteira dos convênios, comprometendo a eficácia da pretendida flexibilização na gestão de recursos, face às reiteradas interferências que representam na legislação específica.

Concernente às limitações para utilização dos recursos, a Lei se restringiu a proibir a realização de despesas com campanhas político-partidárias ou eleitorais (ar. 16), tendo inclusive sido explícita acerca da faculdade de dispêndios vedados em outros diplomas, atendendo a reivindicação e visando ao fortalecimento do terceiro setor. Cite-se, por exemplo, a possibilidade de remuneração de pessoal da própria entidade (art. 10), a flexibilização na gestão de recursos públicos e a ausência de exigência de capacidade já instalada da entidade obrigatória no caso dos convênios. Consta, ademais, a previsão de poder receber bens imóveis, gravados com cláusula de inalienabilidade (art. 15).

Também as vedações têm sido ampliadas pelas LDOs (LDO/2007, LDO/2008 e LDO/2009) que estabeleceram a proibição de pagamento de diárias a militares, servidores e empregados na ativa.

A Lei das OSCIPs previu, ainda, como condição prévia à celebração do termo de parceria, a consulta ao Conselho de Políticas Públicas da área correspondente à do objeto do ajuste (art. 10), se existente. O parecer deste Conselho é meramente opinativo, cabendo ao órgão parceiro decidir pela celebração do termo de parceria. Por este motivo, o TCU já decidiu pertinente alterar a legislação para constar a obrigação do órgão parceiro de justificar a não adoção da posição do Conselho ${ }^{551}$.

Quanto ao controle da regularidade da entidade, a Lei das OSCIPs não exige a sua comprovação prévia, seja com as fazendas federal, estadual e municipal, seja no sistema de seguridade social e FGTS. A entidade deverá apresentar estes últimos dois juntamente com a sua prestação de contas das atividades desenvolvidas como um todo - não restrita ao termo de parceria (art. $4^{\circ}$, VII, b).

\footnotetext{
${ }^{550}$ Lei n. 11.514/2007, art. 40; Lei n. 11.768/08, art. 37 e Projeto de Lei n. 07/08 - CN, art. 37.

${ }^{551}$ Decisão TCU n. 931/99. Plenário. Relator: Marcos Vinicios Vilaça.
} 
Por força do art. $195, \S 3^{\circ}$ da CF, o TCU ${ }^{552}$, no entanto, posicionou-se no sentido de as certidões de débito junto ao INSS e FGTS deverem ser apresentadas antes da assinatura do termo de parceria, além da sua entrega ao término do exercício fiscal, pois, segundo o preceito constitucional, nenhuma pessoa jurídica em débito com o Poder Público poderá dele receber incentivos ou benefícios fiscais ou creditícios.

Observa Natasha Salinas a respeito:

Embora a Lei n. 9.790/99 tenha transferido a exigência de comprovação de regularidade perante a seguridade social para a etapa do controle posterior, visando tornar menos rígido e burocratizado o controle ex ante, o órgão de controle externo entendeu que este dispositivo não se compatibilizava com as demais normas do ordenamento jurídico ${ }^{553}$.

A PI n. 127/08 reiterou a possibilidade de o termo de parceria ser celebrado com previsão de condição a ser observada pela entidade. Enquanto esta não se verificar, não terá efeito a celebração pactuada, devendo extinguir o instrumento se decorrido o prazo estipulado para cumprimento de condição (art. 27). Na citada Portaria, em raros momentos se reporta ao termo de parceria e a previsão acima parece indicar as incidências das mesmas exigências para celebração de convênio e contrato de repasse sobre aquele instrumento, extrapolando a legislação específica.

Ao contrário das OSs, não há previsão expressa na Lei das OSCIPs de poderem receber servidores ou bens públicos por meio do termo de parceria, salvo recursos financeiros a serem depositados em conta bancária específica, com vistas à execução do objeto daquele instrumento ${ }^{554}$, na esteira do art. 14 do Decreto 3.100/99.

\section{c) Contrato de Gestão}

A título de controle prévio sobre o contrato de gestão a ser celebrado com as OS, citase a própria qualificação da entidade como tal, se atendidas as seguintes condições: criação como entidade privada, sem fins lucrativos, cujas atividades sejam dirigidas ao ensino, à pesquisa científica, ao desenvolvimento tecnológico, à proteção e preservação do meio ambiente, à cultura e à saúde, observados os requisitos previstos na Lei das OSs (art. $1^{\mathrm{o}}$, Lei n.

\footnotetext{
${ }^{552}$ Acórdão TCU n. 1.777/2005. Plenário. Relator: Marcos Vinicios Vilaça. DOU, 22 nov. 2005.

${ }^{553}$ Natasha Schmitt Caccia Salinas. Avaliação legislativa no Brasil: um estudo de caso sobre as normas de controle das transferências voluntárias de recursos públicos para entidades do terceiro setor (cit.), 2008. p. 163.

${ }^{554}$ Neste sentido, Gustavo Justino de Oliveira. Contrato de Gestão. (cit), 2008c. p. 280.
} 
9.637/98 $)^{555}$. Segundo o art. 11 da citada Lei, as entidades assim qualificadas são declaradas como de interesse social e utilidade pública, para todos os efeitos legais.

Muito se questiona e se atribui inconstitucionalidade à discricionariedade do administrador para a concessão da qualificação de OS, criticada pela ofensa ao princípio da isonomia $^{556}$.

Não há exigência de prazo entre o nascedouro da entidade até a sua qualificação como OS, tampouco capacidade técnica, jurídica e fiscal para tanto.

Também não há previsão legal a exigir realização de certame (art. $2^{\circ}$, II da Lei das OSs) no momento da qualificação da entidade privada como $\mathrm{OS}^{557}$, para processo de escolha de OS para firmar contrato de gestão ( $\operatorname{art.} 5^{\circ}$ a $7^{\circ}$ da Lei das OSs).

Se a celebração do contrato de gestão tiver como objeto a prestação de serviços públicos de saúde, dever-se-á aplicar a Lei Federal de Concessões - e não a Lei Federal n. 8.666/93 $3^{558}$ para seleção de OSs, segundo Fernando Borges Mânica, por entender tratar-se de serviço público.

O TCU já constatou casos de escolha por meio de seleção sem a estipulação de

${ }^{555}$ Art. $1^{\circ}$. (...) a) comprovar o registro de seu ato constitutivo, dispondo sobre

(i) a natureza social de seus objetivos relativos à respectiva área de atuação;

(ii) finalidade não-lucrativa, com a obrigatoriedade de investimento de seus excedentes financeiros no desenvolvimento das próprias atividades;

(iii) previsão expressa de a entidade ter, como órgãos de deliberação superior e de direção, um conselho de administração e uma diretoria definidos nos termos do estatuto, asseguradas àquele composição e atribuições normativas e de controle básicas previstas nesta Lei;

(iv) previsão de participação, no órgão colegiado de deliberação superior, de representantes do Poder Público e de membros da comunidade, de notória capacidade profissional e idoneidade moral;

(v) composição e atribuições da diretoria;

(vi) obrigatoriedade de publicação anual, no Diário Oficial da União, dos relatórios financeiros e do relatório de execução do contrato de gestão;

(vii) no caso de associação civil, a aceitação de novos associados, na forma do estatuto;

(viii) proibição de distribuição de bens ou de parcela do patrimônio líquido em qualquer hipótese, inclusive em razão de desligamento, retirada ou falecimento de associado ou membro da entidade;

(ix) previsão de incorporação integral do patrimônio, dos legados ou das doações que lhe foram destinados, bem como dos excedentes financeiros decorrentes de suas atividades, em caso de extinção ou desqualificação, ao patrimônio de outra organização social qualificada no âmbito da União, da mesma área de atuação, ou ao patrimônio da União, dos Estados, do Distrito Federal ou dos Municípios, na proporção dos recursos e bens por estes alocados; b) haver aprovação, quanto à conveniência e oportunidade de sua qualificação como organização social, do Ministro ou titular de órgão supervisor ou regulador da área de atividade correspondente ao seu objeto social e do Ministro de Estado da Administração Federal e Reforma do Estado. Cf. art. 2, Lei das OSs.

${ }^{556}$ Cf. Paola Nery Ferrari; Regina Maria Macedo Nery Ferrari. Controle das Organizações Sociais. (cit.), 2007. p. 140; Sílvio Luís Ferreira da Rocha, Terceiro Setor (cit.), 2003. p. 116-117.

${ }^{557}$ O Município de Itupeva, todavia, o faz, como se pode extrair do Edital n. 01/09 para recebimento de pleitos no sentido de qualificação de entidades privadas sem fins lucrativos como organizações sociais. Disponível em: <http://www.itupeva.sp.gov.br. Acesso em: 06 out. 2009.

${ }^{558}$ Fernando Borges Mânica. Participação privada na prestação de serviços públicos de saúde (cit.), 2009. p. 259. 
critérios objetivos ou a seleção por critérios diversos dos estipulados no certame ${ }^{559}$.

No tocante ao controle prévio sobre o contrato de gestão, (supostamente) elaborado de comum acordo entre o órgão ou entidade supervisora e a OS, lembre-se dever ser submetido, após aprovação pelo Conselho de Administração da entidade ${ }^{560}$, ao Ministro de Estado ou autoridade supervisora da área correspondente à atividade fomentada (art. $6^{\circ}$ ). Não há previsão de padrão ou referências para sua elaboração na Lei em comento, salvo a observância dos princípios da legalidade, impessoalidade, moralidade, publicidade e economicidade (art. $6^{\circ}$, caput).

O contrato de gestão deverá obrigatoriamente conter (i) a especificação do programa de trabalho proposto pela OS, a estipulação das metas a serem atingidas e os respectivos prazos de execução, bem como previsão expressa dos critérios objetivos de avaliação de desempenho a serem utilizados, mediante indicadores de qualidade e produtividade; (ii) a estipulação dos limites e critérios para despesa com remuneração e vantagens de qualquer natureza a serem percebidas pelos dirigentes e empregados das OSs, no exercício de suas funções; (iii) a definição, pelos Ministros de Estado ou autoridades supervisoras da área de atuação da entidade, das demais cláusulas dos contratos de gestão (art. $6^{\circ}$, incisos e parágrafo único).

559 O TCU tem verificado casos de irregularidade sob vários aspectos, a exemplo do que segue: “[...] as irregularidades apontadas pela Secex/PA dizem respeito exclusivamente aos procedimentos para contratação da Associação Cultural e Educacional do Pará [...]: b) utilização de critério não previsto no edital de convocação; c) utilização de sistema de pontuação não previsto no edital de convocação; d) atribuição de pontuação não fundamentada em critérios objetivos previstos no edital de convocação; f) aprovação, pelo Conselho Estadual de Saúde, da forma de gerência do hospital, apenas em 17/10/2005, portanto, após a divulgação do edital de convocação e do recebimento das propostas; g) homologação do processo de seleção e contratação da Acepa mesmo diante das irregularidades constatadas" (Cf. Acórdão TCU n. 1752/2008 Ministro Relator Aroldo Cedraz. DOU 19/06/2008).

Em outro caso: “[...] b) utilização pelos técnicos da Sespa, para análise das propostas apresentadas pelas concorrentes em razão do edital de convocação para selecionar organização social para gerenciar o HMUE, de critério não previsto no edital de convocação, a saber: "3 - Atividades não previstas no Edital"; c) utilização pelos técnicos da Sespa, para análise das propostas apresentadas pelas concorrentes em razão do edital de convocação para a organização social para gerenciar o HMUE, de sistema de pontuação não previsto no edital de convocação; d) atribuição pelos técnicos da Sespa, para análise das propostas apresentadas pelas concorrentes em razão do edital de convocação para selecionar organização social para gerenciar o HMUE, de pontuação não fundamentada em critérios objetivos previstos no edital de convocação;" (Acórdão TCU n. 713/2008 - Plenário, DOU 25/04/2008).

${ }^{560}$ O Conselho de Administração tem as seguintes competências:

(i) aprovação de proposta de contrato de gestão da entidade;

(ii) aprovação por maioria, no mínimo, de dois terços de seus membros, do regulamento próprio contendo os procedimentos que deve adotar para a contratação de obras, serviços, compras e alienações e o plano de cargos, salários e benefícios dos empregados da entidade;

(iii) aprovação e encaminhamento, ao órgão supervisor da execução do contrato de gestão, dos relatórios gerenciais e de atividades da entidade, elaborados pela diretoria; e

(iv) fiscalização do cumprimento das diretrizes e metas definidas e aprovação dos demonstrativos financeiros e contábeis e das contas anuais da entidade, com o auxílio de auditoria externa (arts. $3^{\circ}$ e $4^{\circ}$ da Lei das OSs). 
Recursos orçamentários (art. 12) e bens públicos poderão ser objeto de transferências voluntárias às OSs, neste último caso, mediante permissão de uso com dispensa de licitação $\left(\S 3^{\circ}\right)$, sempre podendo sofrer exame pelo TCU.

As LDOs interferem na regulação das OSs e têm estabelecido regras à transferência de recursos públicos, passíveis de controle pelas Cortes de Contas. O TCU, no ano de 2008, julgou irregular contratação por OS de consultoria de servidor público por identificar violação a dispositivo neste sentido na LDO então aplicável ${ }^{561}$. No mesmo ano da citada decisão, no entanto, consignou o dever de anualmente averiguar quais são as proibições constantes das LDOs, pois a contratação por OS de consultoria prestada por servidor público passou a ser regular pela LDO de $2009^{562}$. Outrossim, de se notar entender o TCU aplicável in totum às OSs as LDOs, independentemente do volume de recursos públicos por elas geridos ${ }^{563}$.

\subsubsection{Controle concomitante}

O controle concomitante é realizado durante a execução do instrumento de parceria, a partir do ato de sua celebração. Face às inúmeras malversações, o TCU tem proposto a ampliação do controle concomitante das parcerias, sob pena de ineficácia do controle realizado a posteriori.

Nesta fase, normalmente ocorrem as ações de fiscalização dos órgãos de controle, embora também sejam realizadas após o término da vigência da parceria, servindo suas conclusões de respaldo à avaliação das contas.

Neste sentido, dispõe o art. 212 do RITCU:

As atividades dos órgãos e entidades jurisdicionadas ao Tribunal serão acompanhadas de forma seletiva e concomitante, mediante informações obtidas: Ipela publicação no Diário Oficial da União mediante consulta a sistemas informatizados adotados pela administração pública federal: a) da lei relativa ao plano plurianual, da lei de diretrizes orçamentárias, da lei orçamentária anual e da abertura de créditos adicionais; b) dos editais de licitação, dos extratos de contratos e de convênios, acordos, ajustes, termos de parceria ou outros instrumentos congêneres, bem como dos atos referidos no art. $259^{564}$; II - por meio de expedientes e documentos solicitados pelo Tribunal ou colocados à sua disposição; III - por meio de visitas técnicas ou participações em eventos

\footnotetext{
${ }^{561}$ Acórdão TCU n. 1372/2008 - Primeira Câmara, Ministro Relator Aroldo Cedraz, DOU 05/05/2008.

562 Acórdão TCU n. 4522/2008 - Ministro Relator Aroldo Cedraz, DOU 21/11/2008.

563 Ibid.

${ }^{564} \mathrm{O}$ artigo versa sobre os atos sujeitos a registro, como admissão de pessoal e concessão de aposentadoria.
} 
promovidos por órgãos e entidades da administração pública. ${ }^{565}$

Examinando as atribuições constitucionais do TCU, Evandro Martins Guerra entende que aquelas de controle concomitante estão estipuladas nos incisos III, IV, VII, VII e IX a XI, art. 71 da CF/88: atos sujeitos a registro como admissão de pessoal e concessão de aposentadoria, realização de inspeções e auditorias, fiscalização da aplicação de recursos repassados, prestação de informações solicitadas pelo Congresso Nacional, e indicação de prazo para a adoção de providências, sustação de ato impugnado e representação ao Poder competente sobre irregularidades ou abusos apurados.

Nem todas as hipóteses incidem sobre o terceiro setor, conforme os comentários anteriormente expostos.

a) Convênio e contrato de repasse

O controle concomitante sobre os convênios e contratos de repasse incide sobre a gestão dos recursos públicos, quando a entidade executa o plano de trabalho previamente aprovado, com os recursos públicos a ela transferidos.

Dos objetos passíveis de controle concomitante pertinentes aos convênios e contratos de repasse, destacam-se os seguintes:

Por força da legislação, após a celebração dos convênios e contrato de repasse, os recursos deverão ser transferidos exclusivamente por intermédio de instituição financeira controlada pela União (Decreto $n^{\circ}$ 6.428/2008 e PI n. 127/08) a conta bancária específica para sua execução financeira. Enquanto não utilizados, deverão permanecer em cadernetas de poupança ou fundos de aplicação financeira de curto prazo (art. 10, $\S 4^{\circ}$, Decreto n. 6.170/07), cujos rendimentos deverão ser revertidos ao objeto do convênio, sendo de rigor obedecer ao regramento específico para sua movimentação: somente crédito em conta bancária de titularidade dos fornecedores ou prestadores de serviços (art. 10, $\S 3^{\circ}$, II do Decreto n. 6.170/07), facultada a dispensa deste procedimento por ato da autoridade máxima do concedente ou contratante, devendo o convenente ou contratado identificar o destinatário da despesa por meio do registro dos dados no SICONV (Decreto $n^{\circ} 6.619 / 2008$ ).

Verifica-se, assim, novel regulação de controle do recurso público em relação a sua movimentação pela entidade privada.

Além das cláusulas obrigatórias do convênio, durante a execução do objeto do

${ }^{565}$ Disponível em: <http://www.tcu.gov.br>. Acesso em 03 out. 2008. 
convênio, algumas condutas não poderão ser realizadas pela entidade, por exemplo, a alteração do seu objeto $^{566}$; utilização do recurso em finalidade diversa do pactuado (desvio de finalidade ${ }^{567}$ ) ou em data anterior ou posterior à vigência dos contratos ${ }^{568}$; atribuição de efeito retroativo ao marco inicial ou ao ato de prorrogação da vigência dos convênios (art. 39).

O TCU identificou as irregularidades e as falhas mais freqüentes na execução financeira dos convênios: (i) saque total ou parcial dos recursos do convênio, sem levar em conta o cronograma físico-financeiro de execução do objeto; (ii) realização de despesas fora da vigência do convênio; (iii) saque dos recursos para pagamento de despesas em espécie, sem que haja autorização para isso; (iv) utilização de recursos para finalidade diferente daquela prevista no convênio; (v) utilização de recursos em pagamento de outras despesas do convenente; (vi) pagamento antecipado a fornecedores de bens e serviços; (vii) transferência de recursos da conta corrente específica para outras contas; (viii) retirada de recursos para outras finalidades com posterior ressarcimento; (ix) aceitação de documentação inidônea para comprovação de despesas (notas fiscais falsas, por exemplo); (x) falta de conciliação entre os débitos em conta e os pagamentos efetuados; (xi) não-aplicação ou não-comprovação de contrapartida; (xii) ausência de aplicação de recursos do convênio no mercado financeiro, quando o prazo previsto de utilização for superior a 30 dias; (xiii) uso dos rendimentos de aplicação financeira para finalidade diferente da prevista no convênio; (xx) não devolução do saldo financeiro ao concedente; (xxi) aceitação e apresentação aos órgãos de controle de notas fiscais sem a identificação do número do convênio; (xxii) emissão de cheque ao portador, em vez de nominal ao beneficiário; (xxiii) alteração do objeto do convênio sem autorização prévia do órgão repassador; (xxiv) pagamento sem documento que comprove o recebimento do objeto; (xxv) ausência de medições de serviços e obras e outros elementos de acompanhamento capazes de evidenciar a execução do objeto com os recursos federais repassados ${ }^{569}$.

A PI n. 127/08 pretendeu diminuir os riscos de ocorrência destas irregularidades. Neste sentido, a celebração, a liberação de recursos, o acompanhamento da execução e a

\footnotetext{
${ }^{566}$ A alteração da execução do objeto, sem a devida formalização com o órgão parceiro, poderá dificultar a fiscalização pela Corte de Contas, cabendo o ônus da prova ao convenente quanto a sua regularidade. No mesmo sentido, a alteração de metas.

${ }^{567} \mathrm{O}$ desvio ocorre quando a entidade não obedecer ao objeto pactuado, alterar área de atuação, dentre outros, configurando-se para o TCU em infração grave, que conduz a irregularidade das contas do responsável, com aplicação de multa e responsabilização e devolução de valor por este. Cf. Ubiratan Aguiar et al. Convênios e tomadas de contas especiais: manual prático. [cit.], 2007. p. 47.

${ }^{568}$ Tem se verificado casos em que o gestor já executou o objeto com recursos próprios e somente depois recebeu transferência de recursos públicos, o que pode implicar em presunção de má-fé. Cf. Ibid., p. 49.

${ }^{569}$ BRASIL. TCU. Convênios e Outros Repasses, (cit.), 2008, p. 47.
} 
prestação de contas serão registrados no SICONV e abertos ao público (Portal dos Convênios), segundo o Decreto $n^{\circ}$ 6.619/2008, devendo observar o conteúdo da PI n. 127/08. Segundo o art. 42 desta Portaria e art. 18 da IN. 01/97, a liberação de recursos financeiros deve obedecer ao cronograma de desembolso previsto no Plano de Trabalho e guardar consonância com as metas, fases ou etapas de execução do objeto do convênio. Para recebimento de cada parcela, a entidade deverá demonstrar as mesmas condições da celebração da parceria, o cumprimento da contrapartida e atender as exigências de contratação junto a terceiros, adiante expostas. Para o TCU, os recursos deverão ficar bloqueados até comprovação da regular execução do plano de trabalho, e a liberação de parcelas previstas no cronograma deverão ser precedidas de fiscalização ${ }^{570}$.

Ademais, para cada pagamento, a entidade deverá incluir no SICONV as seguintes informações: (i) destinação do recurso; (ii) nome, CPF/CNPJ do fornecedor; (iii) o contrato a que se refere; (iv) a meta, etapa ou fase do Plano de Trabalho relativa ao pagamento; (v) comprovação de recebimento definitivo do objeto, mediante inclusão no Sistema de notas fiscais ou documentos contábeis.

Há, assim, ritual bastante burocratizado a ser observado, previsto para evitar os incontáveis registros de malversação de recursos públicos. De pouco valerá, todavia, se a própria Administração não se aparelhar e fizer valer a legislação aplicável, pois possui grande responsabilidade pelas irregularidades constatadas pelo TCU - como o caso do artifício de sobrestamento do exame de contas e, assim, garantia de repasse de recursos públicos às entidades cujas contas foram julgadas tardiamente irregulares ${ }^{571}$.

A maior controvérsia, no entanto, consiste no dever de as entidades privadas realizarem certame para contratação de bens e serviços para concretização do objeto de convênio.

No art. 27 da IN STN n. 01/97, previu-se a exigência de adoção de procedimentos análogos aos estabelecidos na Lei Federal n. 8.666/03 e na Lei e Decreto relativos ao pregão, por força do Acórdão Plenário TCU n. 1.070/2003. A questão, entretanto, é controversa entre os Ministros do TCU. No citado Acórdão, o sr. Relator Ubiratan Aguiar entendeu,

\footnotetext{
${ }^{570}$ BRASIL. TCU. Acórdão n. 1562/2009 - Plenário. Min. Relator: Augusto Sherman Cavalcanti. DOU 17/07/09 Disponível em: <http//:www.tcu.gov.br>. Acesso em: 29/07/2009. p. 25.

571 “O procedimento consiste no registro como pendência (sobrestamento) dos valores gastos pelos conveniados sem a devida comprovação, sendo tais quantias abatidas da parcela seguinte a ser liberada. Consoante bem assinalado pela unidade técnica, tal mecanismo não encontra amparo legal na IN/STN n. ${ }^{\circ} 01 / 1997$, além de comprometer a realização das atividades programadas para o período nos planos de trabalho". (Cf. Relatório de Auditoria de Conformidade objeto do Acórdão TCU n. 2697/2008 - Plenário, Ministro Relator Valmir Campelo). Não por outra razão, no Acórdão n 668/2008-TCU-Plenário, o TCU decidiu por determinar à Funasa, que: "9.1.1. cesse o sobrestamento de valores de convênios ou de qualquer outra prática que esteja em desacordo com o art. 35 da IN/STN n. ${ }^{\circ}$ 01/1997 [...]”.
} 
acompanhado por outros quatro Ministros, não ser suficiente as entidades do terceiro setor observarem os princípios da administração pública, devendo fazê-lo por meio da Lei Federal de Licitações. A regra seria a aplicação da Lei, com a ressalva para as entidades que por alguma razão devidamente justificada, se veem impossibilitadas de assim o fazer ${ }^{572}$. Em sentido contrário, todavia, o Ministro Benjamin Zymler manifestou-se pela inaplicabilidade da citada Lei, pois vinculante somente aos entes públicos. As entidades privadas, segundo este Ministro, não se vestiriam de poderes extroversos pela simples celebração de convênio.

Neste contexto, foi editado o Decreto n. 5.504/2005, estabelecendo para aquelas entidades, em decorrência das transferências voluntárias recebidas, a obrigação de adotarem o pregão, de preferência eletrônico, nas contratações de bens e serviços comuns. O citado Decreto foi regulamentado pela Portaria Ministerial Conjunta n. 217/2006 ${ }^{573}$ dos Ministérios do Planejamento, Orçamento e Gestão e Ministério da Fazenda, alterado pela Portaria Ministerial Conjunta n. 150/2007.

Em consonância à relação de órgãos públicos e entidades privadas sem fins lucrativos, bem como em maior harmonia com os institutos de parceria, entretanto, a PI n. 127/08 ${ }^{574}$ não as submeteu à citada legislação e dispôs de maneira bastante diversa a questão - inclusive em afronta ao citado Decreto.

Previu todas as medidas a serem adotadas pelas entidades quando utilizarem os recursos públicos recebidos para contratação de bens e serviços junto a terceiros. No mínimo, dispôs, deverão realizar cotação prévia de preços no mercado (art. 11 do Decreto n. 6.170/07), por meio do SICONV e de procedimento estabelecido na referida Portaria. O SICONV notificará automaticamente as empresas cadastradas no SICAF pertencentes à linha de fornecimento do bem ou serviço a ser contratado, mas ficará a cargo da entidade selecionar,

\footnotetext{
${ }^{572}$ Este entendimento é reiterado na obra do Ministro Ubiratan Aguiar. Convênios e tomadas de contas especiais: manual prático. (cit.), 2007. p. 32.

573 “Art. $1^{\circ}$ Os instrumentos de formalização, renovação ou aditamento de convênios, instrumentos congêneres ou de consórcios públicos que envolvam repasse voluntário de recursos públicos da União para entes públicos ou privados deverão conter cláusula que determine o uso obrigatório do pregão, preferencialmente na forma eletrônica, na contratação de bens e serviços comuns, nos termos da Lei $\mathrm{n}^{\circ} 10.520$, de 17 de julho de 2002, e do Decreto $n^{\circ} 5.450$, de 31 de maio de 2005 (...). Parágrafo único. Até 31 de dezembro de 2006, o disposto neste artigo não se aplica quando o beneficiário da transferência for Organização Social de Interesse Público OSCIP ou Organização - OS, que tenha regulamento próprio para contratação de bens serviços, nos termos da Lei $n^{\circ}$ 9.790, de 23 de março de 1999, e da Lei $n^{\circ}$ 9.637, de 15 de maio de 1998, respectivamente, respeitados os princípios da Lei $\mathrm{n}^{\circ} 8.666$, de 1993, e se destine (...)."

${ }^{574}$ Art. $1^{\circ}$ O parágrafo único do art. $1^{\circ}$ - da Portaria MP/MF n ${ }^{\circ} 217$, de 31 de julho de 2006, passa a ter a seguinte redação: "Art. $1^{\circ}$ (...) "Parágrafo único. Não se aplica o disposto neste artigo até a data de 31 de março de 2008 para os convênios ou instrumentos congêneres firmados com entidades privadas sem fins lucrativos".
} 
em decisão fundamentada, a proposta mais vantajosa segundo os critérios estabelecidos.

A Portaria também previu os casos de dispensa ou inexibilidade da cotação prévia de preços, seja em razão do valor (inferior a $\mathrm{R} \$ 8.000,00$ ) ou natureza do objeto (art. 46). Ainda, consignou a possibilidade de adesão pela entidade a Sistema de Registro de Preços dos entes federados.

De todo modo, a realização ou o registro de contratação pela entidade no SICONV (arts. 46 e 47) será condição de eficácia e liberação de recursos.

Como se vê, a Portaria não se referiu à realização de pregão ou outra modalidade licitatória, representando o citado roteiro expressiva diferença acerca do tratamento da questão e respectivo controle das entidades privadas para fins de dispêndio de recursos públicos recebidos. No entanto, a despeito de proporcionar maior transparência e controle social, o procedimento poderá ser considerado burocrático pelas entidades em exame.

No que concerne ao acompanhamento e fiscalização da execução de convênio e contrato de repasse, a PI n. 127/08 versou detalhadamente (arts. 51 a 55), devendo ser realizada de modo compatível com o Plano de Trabalho a metodologia estabelecida e as metas previstas, inclusive visitas ao local da execução por representante registrado no SICONV.

Outro instrumento para fiscalizar concomitantemente a gestão dos recursos públicos pela ONG é a sua prestação de contas parcial, se o projeto for subdividido em etapas ou fases de execução, com a liberação de recursos em mais de duas parcelas (art. 56 da PI n. 127/08 e art. $21, \S \S 2^{\circ}$ e $3^{\circ}$ da IN STN n. 01/97) ${ }^{575}$.

O TCU identificou que a contratação da CEF para celebração do contrato de repasse apresenta vantagem em comparação aos outros procedimentos, por liberar recursos de acordo com a medição do serviço executado. Este procedimento é reforçado pelo registro da celebração no SICONV, da liberação de recursos, do acompanhamento da execução e da prestação de contas, e controle público pelo "Portal dos Convênios" (Decreto nº 6.619/2008).

\section{b) Termo de Parceria}

Como instrumento de controle concomitante do termo de parceria, cita-se o acompanhamento e a fiscalização por uma Comissão de Avaliação a ser integrada por um representante da OSCIP, outro do Conselho de Políticas Públicas e dois do órgão público parceiro (art. 11 da Lei das OSCIPs). É de sua responsabilidade acompanhar e avaliar a

\footnotetext{
${ }^{575}$ No Acórdão Plenário TCU n. 788/2006 verificou-se plano de trabalho prevendo liberação de recursos em duas parcelas para escapar desta regra.
} 
execução do objeto do termo de parceria, emitindo relatórios periódicos com o andamento do projeto, permitindo a correção de alguma ação. A referida Comissão também é responsável pelo relatório final contendo informações sobre o que foi efetivado, a verificação do alcance das metas e a avaliação geral do sucesso da parceria. Em pesquisa realizada, Valéria Maria Trezza verificou a dificuldade dos órgãos parceiros para a concretização desta Comissão ${ }^{576}$, lembrando-se a possibilidade de os relatórios por ela emitidos configurarem-se em importante instrumento de controle pelo TCU.

A legislação não define se o papel daquela Comissão é apenas deliberativo ou também fiscalizatório, tampouco determina diretrizes para o acompanhamento da execução do objeto do termo de parceria. A "inexistência de um detalhamento normativo para operacionalizar o controle concomitante", provoca "insegurança no setor público, que tende a se pautar pelos critérios estabelecidos na legislação que disciplina os convênios" ${ }^{\text {"577. }}$.

Outro instrumento importante de controle concomitante é o regulamento a ser editado pela OSCIP para compras de bens e serviços pagos com recursos públicos recebidos por meio de termo de parceria (art. 14 da Lei das OSCIPs), cujo intuito foi justamente flexibilizar o exame de sua gestão. As OSCIPs, por força de lei, não são obrigadas a cumprir a Lei 8. 666/93, salvo os princípios da legalidade, eficiência, publicidade, moralidade, impessoalidade e economicidade $\left(\operatorname{art.} 4^{\circ}\right)$.

Mas o Decreto Federal n. 5.504/2005 estabeleceu a obrigatoriedade de realização de pregão para contratação de bens e serviços comuns por quaisquer pessoas sem fins lucrativos beneficiárias de transferências voluntárias, incluindo as OSCIPs (art. $1^{\circ}, \S 5^{\circ}$ ), e, ainda, determinou a inclusão dos dados a respeito das parcerias celebradas com entidades privadas no Sistema Integrado de Administração de Serviços Gerais - SIASG.

O citado Decreto restringiu a pretendida flexibilização prevista em Lei, reiterado pela Portaria Interministerial MF/MPOG n. 217/2006 que exigiu, após 31/12/2006, a adoção do pregão pelas OSCIPs.

No próprio TCU, há manifestações $\operatorname{contrárias~}^{578}$ e a favor $^{579}$ à aplicabilidade da Lei

\footnotetext{
${ }^{576}$ Valéria Maria Trezza. O termo da parceria como instrumento de relação público/privado sem fins lucrativos: o difícil equilíbrio entre flexibilidade e controle, (cit.), 2007. p. 122-124.

${ }^{577}$ Natasha Schmitt Caccia Salinas. Avaliação legislativa no Brasil: um estudo de caso sobre as normas de controle das transferências voluntárias de recursos públicos para entidades do terceiro setor (cit.), 2008. p. 164 -165.

${ }^{578}$ O TCU já entendeu que as OSCIPs não se sujeitam aos ditames da Lei Federal n. 8.666.93. (cf. Acórdão n. 1.777/2005. Plenário. Relator Marcos Vinicios Vilaça. DOU. 22 nov. 2005).

${ }^{579}$ O TCU, em que pese consignar que a OSCIP auditada não era submetida aos princípios da Lei de Licitações e regras do Decreto n. 5.5.04/2005, porque vinculada a Lei das OSCIPs, ao constatar falhas no regulamento interno da OSCIP e sua concretização, sugeriu a sua alteração, inclusive para fazer constar a utilização da
} 
Federal n.8.666/93 ou do Decreto n.5.504/05 nos termos de parceria celebrados com as OSCIPs.

Ademais, verifica-se a aplicação de conceitos e práticas relativas aos convênios sobre os termos de parceria e os contratos celebrados com terceiros pelas entidades do terceiro setor. Neste sentido, há previsão na PI n. 127/08 de obrigatoriedade de inclusão de inúmeros dados de gestão da parceria no SICONV: a celebração, a liberação de recursos, o acompanhamento da execução e a prestação de contas - semelhante ao regime dos convênios.

No entanto, ainda permanece a maior flexibilização na execução financeira na Lei das OSCIPs, pois previu a possibilidade de prorrogação do prazo de vigência do termo de parceria, se disponíveis recursos financeiros para tanto ou quando o seu escopo não tenha sido finalizado tempestivamente. A citada Lei, outrossim, não estabelece as mesmas regras aplicáveis aos convênios quanto a movimentação financeira (a aplicação financeira, movimentação por cheque nominativo, dentre outros), de modo que as entidades pudessem "empreender mais esforços na busca por resultados e realização de metas do que no cumprimento de regras de aplicação de recursos públicos" $" 580$.

c) Contrato de Gestão

Acerca dos instrumentos de controle concomitante dos contratos de gestão celebrados com as OSs, segundo a Lei, estas deverão apresentar relatório pertinente à sua execução ao órgão ou entidade do Poder Público supervisor signatário do contrato, a qualquer momento, conforme recomende o interesse público, contendo comparativo específico das metas propostas com os resultados alcançados, acompanhado da prestação de contas relativa ao exercício financeiro.

Segundo a Lei das OSs, os resultados atingidos com a execução do contrato de gestão devem ser analisados periodicamente por comissão de avaliação indicada pela autoridade supervisora da área correspondente, composta por especialistas de notória capacidade e adequada qualificação. Esta comissão deve encaminhar à autoridade supervisora relatório conclusivo sobre a avaliação procedida.

modalidade pregão. Ressalta-se que o Ministro Relator foi explícito no sentido de que em alguns casos o TCU deve se limitar a proferir recomendação à entidade vez que não lhe cabe impor a adoção de procedimentos e parâmetros próprios da Lei n. 8.666/93. Por outro lado, por via transversa, entendeu que poderia determinar ao órgão público parceiro (Ministério do Turismo) que se abstivesse de repassar valores federais, ainda que no âmbito de termos de parceria, a entidade que não adotasse recomendação do TCU, assegurando o cumprimento do citado Decreto. (cf. Acórdão n. 1386/2009. Plenário. Relator: André Luis de Carvalho. Sessão de 24/06/2009. Disponível em: <http//:www.tcu.gov.br>. Acesso em: 29/07/2009).

${ }^{580}$ Natasha Schmitt Caccia Salinas. Avaliação legislativa no Brasil: um estudo de caso sobre as normas de controle das transferências voluntárias de recursos públicos para entidades do terceiro setor (cit.), 2008. p. 173. 
Não cabe aqui versar novamente sobre a competência do TCU para receber e julgar as contas das OSs, ainda que parciais. Pretende-se, apenas, dispor sobre o que o TCU poderá verificar em termos de observância da legislação pelo órgão público e privado sobre o tema.

Quanto aos bens móveis públicos cedidos para uso, a entidade poderá permutá-los por outros de igual ou maior valor, condicionado a os novos bens integrarem o patrimônio da União. A permuta dependerá de prévia avaliação do bem e expressa autorização do Poder Público, podendo os Tribunais de Contas acompanhar concomitantemente estas tratativas.

Sobre a questão da exigência de observância da Lei Federal de Licitações n. 8.666/93, seguindo os ensinamentos de Gustavo Justino de Oliveira, pode ser enfocada sob cinco aspectos: (i) momento da qualificação da entidade privada como uma OS - para a qual não há previsão legal a exigir realização de certame (art. $2^{\circ}$, II da Lei das OSs); (ii) processo de escolha da OS que firmará com o Poder Público um contrato de gestão - para a qual não há exigência legal (arts. $5^{\circ}$ a $7^{\circ}$ da Lei das OSs); (iii) contratações diretas das OSs por órgãos públicos, derivadas do contrato de gestão - (art. 24, XXIV da Lei de Licitações); (iv) OSs como contratantes de empresas prestadoras de serviços, de fornecimento de bens e de realização de obras - para esta situação a Lei das OSs previu a edição de regulamento próprio (art. 17), e (v) destinação de bens públicos a OSs por meio de permissão de uso - para este caso a Lei previu dispensa de licitação, devendo constar do contrato de gestão $\left(\operatorname{art.} 12, \S 3^{\circ}\right)^{581}$.

Fernando Borges Mânica ${ }^{582}$ argumenta no sentido da não aplicabilidade da Lei Federal n. 8.666/93 às OSs para contratação por estas de bens e prestação de serviços junto a terceiros, dentre outros fundamentos, pois (i) a Lei que as disciplina assim não o determinou, tendo sido clara no sentido da edição de estatuto próprio de compras e serviços; (ii) não se trata de caso de fomento estatal; e (iii) a Lei de Licitações e Contratos não se aplica a entidades privadas.

Todavia, pelo Acórdão n. 601/2007 - Primeira Câmara, o TCU entendeu estarem as OSs submetidas às normas gerais de licitação e de administração financeira do poder público, a despeito de a legislação estabelecer a sua obrigação de elaborar regulamento próprio (Lei 9.637/98, art. $4^{\circ}$, VIII e 17). Para aquela Corte, este regulamento "estaria autorizado apenas a detalhar a legislação pertinente e amoldá-las às peculiaridades da organização social"

Em sentido oposto à mencionada decisão, foi proferido o Acórdão TCU n. 1952/2007,

\footnotetext{
581 Gustavo Justino de Oliveira. Constitucionalidade da Lei Federal n ${ }^{\circ}$ 9.637/98, das Organizações Sociais: comentários à medida cautelar da Adin n. 1.923-DF, do Supremo Tribunal Federal. Revista de Direito do Terceiro Setor, Belo Horizonte, ano 1, n. 2, jul./dez. 2007c. p. 209.

${ }^{582}$ Fernando Borges Mânica. Participação privada na prestação de serviços públicos de saúde (cit.), 2009. p. 259.

${ }^{583}$ Acórdão n. 601/2007-Primeira Câmara, p. 14.
} 
contendo a seguinte doutrina de Lucas Rocha Furtado:

A atividade fiscalizadora deverá adequar-se à verificação de resultados, tendo em conta a não-submissão das OCs ao regime jurídico de Direito Público, inclusive quanto ao dever de licitar, de celebrar contratos administrativos ou realizar concursos. Dessa flexibilização, decorre que o controle da legalidade deve ceder ao controle de resultados ou finalístico ${ }^{584}$. A aferição dos resultados e, sobretudo, a satisfação do usuário devem ser o parâmetro da atividade dessas entidades ${ }^{585}$.

Em 2008, ao debater-se amplamente se e quais princípios seriam aplicáveis às OSs, o pensamento flexibilizador do citado autor foi ventilado no Acórdão n. 1111/2008-Plenário, mas acabou por não prevalecer integralmente.

Defendeu-se, naquela ocasião, a existência na legislação federal das OSs de obrigatoriedade de respeito aos princípios da Administração Pública no âmbito do contrato de gestão (art. $7^{\circ}$ ) - enquanto para as OSCIPs (art. 4 $4^{\circ}$ I), no estatuto social. Assim, após celebração do contrato de gestão, as OSs passam a submeter-se a regime próximo do publicista, motivo pelo qual deverão observar os seus princípios nos atos de dispêndio de recursos públicos recebidos por meio dele, inclusive custeio de pessoal. Ressaltou-se, inclusive, o "controle moderado ou flexibilizado de legalidade, vez que não se está a exigir, como regra, a observância de normas estritamente administrativistas, [...] mas tão-somente que sejam observados princípios, valores de ordem pública na condução de seus procedimentos". Para o relator daquele Acórdão, "o controle de resultados não afasta a incidência da observância, nas ações administrativas e operacionais da entidade qualificada, de referidas normas de caráter principiológico".

Pelo exposto, na esteira do TCU, as OSs configuram-se como pessoas jurídicas de natureza privada, cujo regime é parcialmente alterado em razão das parcerias celebradas e dos recursos públicos recebidos e, assim, vincular-se-ão aos princípios publicistas, controlando-se os aspectos orçamentário-financeiros e "a qualidade dos serviços prestados"586.

A despeito do acima exposto, já o Decreto Federal n. 5.504/2005 estabeleceu a obrigatoriedade de realização de pregão para contratação de bens e serviços comuns por quaisquer pessoas sem fins lucrativos beneficiárias de transferências voluntárias, inclusive as

\footnotetext{
${ }^{584}$ Neste mesmo sentido, conferir Benjamin Zymler, segundo o qual "O padrão avaliador a ser utilizado pelo controle externo passa a ser o conteúdo e o fiel cumprimento do contrato de gestão, pois nele devem estar fixados adequadamente os objetivos e metas da entidade, bem como os critérios e os parâmetros de avaliação quantitativa e qualitativa (padrões de desempenho)". Direito Administrativo e Controle. (cit.), 2005. p. 306.

${ }^{585}$ Lucas Rocha Furtado. Curso de Direito Administrativo, (cit.), 2007. p. 347.

${ }^{586}$ Simone de Castro Tavares Coelho. Terceiro setor: um estudo comparado entre Brasil e Estados Unidos. São Paulo: SENAC, 2000. p. 97.
} 
OSs (art. $\left.1^{\circ}, \S 5\right){ }^{587}$, e determinou que os dados a respeito fossem incluídos no Sistema Integrado de Administração de Serviços Gerais - SIASG. Por força da Portaria Interministerial MF/MPOG n. 217/2006, após 31/12/2006, as OSs tiveram que adotar o pregão segundo a legislação específica.

O TCU já examinou representações formuladas por licitantes em razão de pregão eletrônico realizado por OSs, como no Acórdão TCU n. 1270/2007 - Plenário, quando determinou a suspensão cautelar do certame, em face de irregularidades constatadas ${ }^{588}$. Sem adentrar no mérito destas, extrai-se que as atividades das OSs, em tese dotadas de maior flexibilidade, passaram a sofrer as mesmas regras incidentes sobre a Administração Pública, inclusive pelo órgão de controle externo - nem sempre de eficiência e moralidade garantidas.

Saliente-se que o controle deveria ter, segundo o art. 20, incisos I e II da Lei das OSs, ênfase no atendimento ao cidadão-cliente e nos resultados qualitativos e quantitativos nos prazos pactuados. Ainda, deveria ser realizado concomitantemente à execução do contrato, além do a posteriori, a fim de possibilitar readequação tempestiva ${ }^{589}$.

\subsubsection{Controle sucessivo ou a posteriori}

Mario Mora Quirós, ao versar sobre o controle a posteriori de resultado, observa:

Como política de Estado, a responsabilização pelos resultados pressupõe a consolidação gradual de um modelo de gestão pública flexível e criativo, que outorgue aos responsáveis pelos programas maior liberdade para tomar decisões e administrar os recursos, assim como maior responsabilização pessoal pelos resultados obtidos. A avaliação é incorporada como um instrumento de gerência pública ao longo de todo o processo de gestão, mas o objetivo final da responsabilização é melhorar o desempenho público, e não a avaliação ex post como um fim em si mesmo.

Para avançar nessa direção, é preciso criar um ambiente propício que garanta a integração dinâmica de três processos que determinam o surgimento de uma cultura pública orientada pelos resultados: a programação, para assegurar que a alocação dos recursos seja consistente com as prioridades nacionais e as demandas sociais; $a$ execução, por meio da fixação de metas, do acompanhamento dos programas e do estabelecimento de controles seletivos para orientar a tomada de decisões; e a avaliação, como condição necessária para medir o desempenho público em função dos resultados e colocar em prática a prestação de contas ${ }^{590}$.

\footnotetext{
${ }^{587}$ O TCU já havia se posicionado no sentido de que as OSs devem se submeter a normas gerais de licitação e de administração financeira do poder público. (Acórdão n. 601/2007, 1 Câmara, Min. Rel. Aroldo Cedraz).

588 Neste sentido, o Acórdão TCU n. 808/2008-Plenário, tendo como Ministro relator Augusto Sherman Cavalcanti.

${ }^{589}$ Paola Nery Ferrari; Regina Maria Macedo Nery Ferrari. Controle das Organizações Sociais. (cit.), 2007. p. 140; Sílvio Luís Ferreira da Rocha, Terceiro Setor (cit.), 2003. p. 151.

${ }^{590}$ Mario Mora Quirós. Responsabilização pelo controle de resultados (cit.), 2006. p. 170.
} 
O controle pelos Tribunais de Contas, já se disse, realiza-se precipuamente $a$ posteriori $^{591}$, pois o arcabouço legal no sentido de sancionar e reparar desvios, extravios ou irregularidades que causem prejuizo ao erário não tem surtido os almejados efeitos preventivo e sancionador, pela ausência ou ineficiência ${ }^{592}$ do controle prévio e concomitante por parte dos órgãos públicos parceiros e do controle externo.

Sobre o controle a priori e concomitante, foi mencionado ter a legislação procurado evoluir no sentido de sua implementação, a fim de evitar tais irregularidades.

As atribuições constitucionais relativas ao controle posterior das parcerias e entidades do terceiro setor são as estipuladas nos incisos II, IV, VI, VIII, IX e XI, art. 71, CF/88: julgamento das contas dos gestores, realização de inspeções e auditorias, fiscalização da aplicação dos recursos públicos, aplicação de sanções, indicação de prazo para que a entidade adote providências para cumprimento de lei. Examinados a seguir os objetos legais de controle a posteriori.

a) Convênio e contrato de repasse

O controle a posteriori dos convênios e contratos de repasse refere-se ao momento da demonstração, por meio da prestação de contas e apresentação de vários documentos (art. 28 da IN STN n. 01/97 e 58 da Portaria Interministerial n. 127/08) atestando (i) a utilização dos recursos públicos e (ii) a não geração de dano ou prejuízo ao erário por parte das entidades do terceiro setor. A obrigação é personalíssima, devendo o gestor responder por ela, inclusive com patrimônio pessoal.

\footnotetext{
591 “O modelo de controle 'a posteriori’ sofreu grande expansão, mas também não é hoje o adotado de forma exclusiva por muitos países, uma vez que sua utilidade é pequena e elevado o seu custo para os órgãos de controle - inclusive com críticas de inutilidade", como destacado por Antônio Roque Citadini. O Controle Externo da Administração Pública. São Paulo: Max Limonad, 1995. p. 39.

Ademais, como ressalta Andréa Nunes, “[...] em se tratando de contratos, a físcalização apenas a posteriori dos mesmos pelos Tribunais de Contas é solução que deixa a desejar em termos de controle". Terceiro Setor: controle e fiscalização. (cit.), 2006. p. 96.

${ }^{592}$ As "prestações de contas se acumulam nos órgãos repassadores, carentes de pessoal e meios, em quantidade e qualidade, para analisá-las. Convenentes se omitem no dever de prestar contas. O atraso médio, em toda a administração pública federal, é de 3,9 anos na entrega de prestações de contas, e de 5,4 anos a idade média dos processos aguardando análises, perfazendo um montante de R\$12,5 bilhões em recursos, cuja aplicação o governo desconhece os resultados. Esse fato, associado à falta de registro no Siafi da adimplência da entidade convenente, permite que muitos entes da Federação e organizações não-governamentais continuem a receber recursos públicos sem que tenham prestado contas ou tenham tido suas prestações de contas sequer analisadas, quanto à boa e regular aplicação dos recursos anteriormente recebidos." Cf. BRASIL, TCU, Relatório e pareceres prévios sobre as contas do Governo da República - exercício 2006. Brasília-DF: TCU, 2007. Disponível em: <www.tcu.gov.br>. Acesso em: 12 de maio de 2009.
} 
Dentre os documentos exigidos, cita-se (i) o relatório de cumprimento de objeto, (ii) a relação de bens adquiridos, produzidos ou construídos, (iii) a relação de serviços prestados, (iv) o comprovante de recolhimento do saldo de recursos, (v) os documentos relativos às despesas - como o extrato bancário de contas específicas, ficando arquivadas as provas por cinco anos ${ }^{593}$. Segundo o art. 57 da Portaria Interministerial n. 127/08, os saldos financeiros remanescentes deverão ser devolvidos à entidade ou órgão repassador de recursos - não incentivando a eficiência e a economicidade por parte das entidades privadas.

O representante fiscalizador deve registrar no SICONV o recebimento de prestação de contas. Em caso de não recebimento da prestação de contas e adotadas todas as medidas cabíveis para tanto, a autoridade competente - não o TCU - tomará as providências para a instauração de Tomada de Contas Especial (PI n. 127/08, art. 60, § 2).

Os instrumentos normativos vigentes não oferecem parâmetros de avaliação da execução física dos projetos vinculados a programas orçamentários; além disso, o controle da execução física e financeira dos projetos é muito deficitário, comprometendo a análise final das prestações de contas. Não por outra razão, o $\mathrm{TCU}^{594}$ tem reiteradamente identificado a ausência de controle anterior e concomitante dos convênios, tornando o controle posterior inócuo. Ainda que realizados tais controles, o Tribunal tem encontrado em suas auditorias inúmeras prestações de contas aprovadas com várias irregularidades, inclusive quanto aos documentos comprobatórios de despesas e resultados da execução de projetos.

Em termos de fiscalização, há expectativa de o ritual previsto no SICONV auxiliar a aprimorar este quadro, em que pese a inclusão de informações pelos próprios interessados.

O Decreto n. 6.170/2007, reiterado pelo art. 60 da PI n. 127/2008, estabeleceu o prazo de noventa dias para o ordenador de despesa examinar as contas prestadas. A demora injustificada, segundo o TCU, pode ensejar responsabilidade do gestor ${ }^{595}$.

b) Termo de Parceria

O instrumento de controle posterior por excelência dos termos de parceria é também a prestação de $\operatorname{contas}^{596}$ das ações realizadas e dos gastos efetuados, instruída com os

\footnotetext{
${ }^{593}$ Cf. Ubiratan Aguiar et al. Convênios e tomadas de contas especiais: manual prático. (cit.), 2007. p. 53

${ }^{594}$ Cf. Acórdão TCU n. 788/2006. Plenário. Relator: Augusto Sherman Cavalcanti. DOU, 26 mai. 2006.

${ }^{595}$ Guilherme Henrique de La Rocque Almeida. Controle das transferências financeiras da União, (cit.), 2008 a. p. 181.

${ }^{596}$ Além da prestação de contas quanto ao termo de parceria, a OSCIP deverá prestar contas anualmente ao Ministério da Justiça das atividades por ela desenvolvidas, munida dos seguintes documentos (art. 4, VII da
} 
seguintes documentos ${ }^{597}$ :

(i) relatório sobre a execução do objeto do termo de parceria, contendo comparativo entre as metas propostas e os resultados alcançados; (ii) demonstrativo integral da receita e despesa realizadas na execução; (iii) parecer e relatório de auditoria, nos casos em que o montante de recursos recebidos for maior ou igual a $\mathrm{R} \$ 600.000,00$ (seiscentos mil reais); (iv) extrato da execução física e financeira, preenchido pela OSCIP e publicado por iniciativa do órgão público na imprensa oficial ${ }^{598}$.

É novidade da Lei da OSCIPs a obrigatoriedade de apresentação de relatório de resultados alcançados e de relatório de auditoria independente, em parcerias de valor acima de R \$ 600 mil. O Decreto n. 3.100/99 (art. 19, $\S 3^{\circ}$ ) autorizou a inclusão no orçamento do projeto das despesas com esta auditoria, sem indicação do momento no qual deverá ser realizada - no curso ou depois da execução do objeto da parceria.

A principal inovação introduzida foi a exigência de apresentação de demonstrações contábeis da entidade, instituída para maior transparência, mas ainda não aprovada a sua adequação para aferição do desempenho das entidades do terceiro setor. Esta inovação, no entanto, facilitará a fiscalização contábil de competência do TCU.

Quanto à proposta do termo de parceria de mudar a forma de prestação de contas de recursos obtidos do Poder Público para análise do alcance de resultados, Valéria Maria Trezza verificou o seguinte: (i) não foi assimilada por alguns órgãos públicos, (ii) o exame se restringe mais à contabilidade, ao aspecto financeiro do que de gestão, (iii) o controle de resultados encontra barreira na precariedade de recursos humanos e físicos dos órgãos

Lei 9. 970/99 e art. 11 do Decreto n. 3.100/99):

(i) relatório anual de execução de atividades;

(ii) demonstração de resultados do exercício;

(iii) incluindo-se as certidões negativas de débitos junto ao INSS e ao FGTS;

(iv) balanço patrimonial;

(v) demonstração das origens e aplicações de recursos;

(vi) demonstração das mutações do patrimônio social;

(vii) notas explicativas das demonstrações contábeis, caso necessário;

(viii) parecer e relatório de auditoria somente quando os recursos públicos recebidos pela OSCIP forem equivalentes ou superiores a R\$600.000,00.

Natasha Schmitt Caccia Salinas. Avaliação legislativa no Brasil: um estudo de caso sobre as normas de controle das transferências voluntárias de recursos públicos para entidades do terceiro setor (cit.), 2008. p. 168.

${ }^{597}$ O TCU tem exigido a observância da Lei: “5.5. Determinar à Prefeitura Municipal de Itacuruba que: [...] c) exija das Oscips parceiras, a organização dos termos de parceria em processos, contendo todos os documentos arrolados no $\S 2^{\circ}$ do art. 10 da Lei $n^{\circ} 9.790 / 1999$, inclusive os programas de trabalho detalhados, bem como a apresentação das prestações de contas e os comprovantes de despesas referentes a todos os gastos, de conformidade com os arts. 11 e 12 do Decreto $\mathrm{n}^{\mathrm{o}} 3.100 / 99$, com a inserção dos documentos no processo em ordem cronológica dos eventos, com numeração das folhas e colocação da rubrica do responsável pela inserção, contribuindo para a devida transparência dos atos de gestão pública”. Cf. Acórdão TCU n. 715/2008 - Primeira Câmara - Ministro Relator Valmir Campelo. DOU 14/03/2008.

${ }^{598}$ Natasha Schmitt Caccia Salinas. Avaliação legislativa no Brasil: um estudo de caso sobre as normas de controle das transferências voluntárias de recursos públicos para entidades do terceiro setor (cit.), 2008. p. 166. 
parceiros, (iv) provocou em alguns órgãos a separação de controle contábil e técnico ${ }^{599}$.

A avaliação do alcance de resultados do controle de gestão dependerá do caso concreto, restando prejudicado nesta dissertação o exame aprofundado da efetividade do controle neste sentido.

\title{
c) Contrato de Gestão
}

$\mathrm{Na}$ esteira do controle concomitante, ao término do contrato de gestão, as OSs são obrigadas a apresentar ao órgão do Poder Público supervisor signatário do contrato, relatório pertinente à sua execução. Deverá conter comparativo específico das metas propostas e os resultados alcançados, acompanhado da prestação de contas correspondente, nos termos previstos no contrato, sem prejuízo dos relatórios e da prestação de contas parcial, a cada exercício financeiro, em atendimento ao art. $8^{\circ}, \S 1^{\underline{0}}$ Lei das OSs.

Assim, a verificação do atingimento das metas previstas no contrato de gestão são realizadas mediante a apresentação de relatórios anuais ao término do exercício financeiro $\left(\S 2^{\circ} \text { do art. } 8^{\circ} \text { da Lei das OSs }\right)^{600}$. E, para esta finalidade, segundo o voto do Ministro-Relator da Decisão TCU n. 592/1998 - Plenário, considerando as características e as finalidades pretendidas com os contratos de gestão, "o controle da legalidade deve ceder espaço ao controle teleológico ou finalístico", e ainda:

\begin{abstract}
A aferição de resultados e, sobretudo, a satisfação do usuário serão a tônica da atividade controladora dos setores externos ao núcleo burocrático do Estado. Essa orientação para os resultados estará fixada em parâmetros concretos, objetivados no contrato de gestão. O padrão avaliador a ser utilizado pelo Controle Externo passa a ser o conteúdo e o fiel cumprimento do contrato de gestão, pois nele devem estar fixados adequadamente os objetivos e metas da entidade, bem como os critérios e parâmetros de avaliação quantitativa e qualitativa (indicadores de desempenho).
\end{abstract}

O TCU, no Acórdão n. 2640/2008 - Primeira Câmara, ratificando o já exposto acerca do controle de resultado, enfatizou "que a transferência do foco da ação fiscalizadora (que passaria a privilegiar o controle de resultados) não importa no abandono ou enfraquecimento dos controles da legalidade, da forma da execução das despesas e do uso regular dos recursos públicos".

\footnotetext{
${ }^{599}$ Valéria Maria Trezza. O termo da parceria como instrumento de relação público/privado sem fins lucrativos: o difícil equilibrio entre flexibilidade e controle. (cit.), 2007. p. 124-126.

${ }^{600}$ Paola Nery Ferrari; Regina Maria Macedo Nery Ferrari. Controle das Organizações Sociais. (cit.), 2007. p. 140; Sílvio Luís Ferreira da Rocha, Terceiro Setor (cit.), 2003. p. 151.
} 
Neste mesmo Acórdão, asseverou-se: "não se pode admitir que a prestação de contas de um Contrato de Gestão possa resumir-se a demonstrar a consecução dos objetivos estratégicos, metas e indicadores constantes do Plano de Trabalho, sem, contudo, demonstrar a forma como se deu a aplicação da totalidade dos recursos públicos repassados".

Alguns Tribunais de Contas, como visto anteriormente, regulamentaram o modo de as OSs prestar contas e como a administração pública deverá examiná-las ${ }^{601}$, tendo o TCU alterado seu entendimento no sentido de não ter competência para receber a prestação de contas diretamente das OSs. O órgão público parceiro deverá examiná-las, acompanhar e verificar as contas prestadas, bem como emitir relatório de gestão, a ser anexado e julgado pelo TCU em conjunto com a sua própria prestação de contas, sem prejuízo de sua jurisdição sobre as OSs ${ }^{602}$.

Desta forma, o controle ordinário do TCU volta-se aos entes da Administração Pública, não atuando direta e constantemente sobre as OSs. As contas por elas prestadas não serão objeto de exame por aquele Tribunal, salvo se constatada alguma irregularidade. Neste caso, a análise e o julgamento não se darão pela tomada e prestação de contas, conforme a seguir exposto.

\subsection{Procedimentos de controle}

Na Lei Orgânica e no Regimento Interno do TCU, além da legislação específica, constam os procedimentos a serem adotados para fins de controle dos seus jurisdicionados.

Nos dois capítulos iniciais do Título II da Lei Orgânica, disciplinaram-se os processos de julgamento de contas e de fiscalização. Previu-se neste último, em seções específicas, os processos típicos de físcalização, os destinados a apreciação da legalidade de atos sujeitos ao registro e processos especiais de fiscalização decorrentes de iniciativa do Congresso Nacional. A denúncia e a consulta receberam tratamento em capítulos individuais. A representação foi

\footnotetext{
${ }^{601}$ Conferir a Resolução n. 0020/2005 do Tribunal de Contas do Estado de Pernambuco, que regulamentou a matéria. Disponível em < http://www.tce.pe.gov.br/resolucao-virtual/2005/r202005.htm>. Acesso em 29 set. 2008.

602 “14. Nesse contexto, no caso das Organizações Sociais o Tribunal, no uso do poder regulamentar que lhe confere o art. $3^{\circ}$ da Lei $n^{\circ} 8.443$, de 16 de julho de 1992, decidiu pela não-obrigatoriedade de prestação de contas, tendo em vista que os órgãos governamentais contratantes (supervisores) dessas entidades já devem, por disposição legal, supervisioná-las, acompanhá-las e avaliá-las. No entanto, os relatórios de gestão dos supervisores das OS, deverão conter informações sobre o acompanhamento e a avaliação das entidades que celebram contrato de gestão, conforme disposto no item 19 da parte 2 do anexo II da DN/TCU 85/2007. 15. É importante ressaltar que o fato de o órgão ou entidade ter sido dispensado da apresentação de contas não significa que foi excluído da jurisdição do Tribunal, eis que a condição de jurisdicionado decorre de mandamento constitucional (arts. 70, parágrafo único, e 71)”. (cf. Acórdão TCU n. 4522/2008 - Ministro Relator Aroldo Cedraz DOU 21/11/2008). Neste mesmo sentido, verificar o Acórdão TCU Plenário $\mathrm{n}$. 613/2008, Ministro Relator Raimundo Correa, DOU 14/04/2008.
} 
tratada no art. 237 do RITCU ${ }^{603}$.

Serão indicados, em linhas gerais, os principais processos de competência do TCU passíveis de incidência sobre as entidades do terceiro setor.

Não se pretende esmiuçar a tramitação dos procedimentos de fiscalização, bastando lembrar, sinteticamente, possuírem a seguinte forma: $1^{\mathrm{a}}$ fase - análise técnica; $2^{\mathrm{a}}$ fase manifestação do representante do Ministério Público junto ao Tribunal de Contas, se pertinente; $3^{\mathrm{a}}$ fase - relatório e voto do relator; $4^{\mathrm{a}}$ fase - decisão do colegiado; e $5^{\mathrm{a}}$ fase - recursos cabíveis ${ }^{604}$.

A fiscalização dos instrumentos de parceria é feita por meio de levantamento, auditoria, inspeção, acompanhamento e monitoramento. O TCU poderá instaurar TCE nos casos de omissão de prestação de contas de recursos recebidos, irregularidade em sua aplicação, dentre outros ${ }^{605}$, como será oportunamente versado ${ }^{606}$.

Para Benjamin Zymler, os procedimentos de fiscalização adotados pelo TCU têm por fim mediato subsidiar o julgamento das contas dos gestores públicos. Segundo o autor, os processos de fiscalização possuem caráter subsidiário e acessório em relação aos processos de contas, pois, autorizada a sua realização, serão incorporados nos relatórios das unidades técnicas ${ }^{607}$.

Neste sentido, a título de exemplo, o TCU é competente (art. 71, IV, CF) para fiscalizar os atos de que resultem receita ou despesa e esta fiscalização tem por fim, essencialmente, assegurar a eficácia do controle e instruir o julgamento das contas (Lei Orgânica do TCU, art. 41).

\footnotetext{
${ }^{603}$ A representação não será objeto de análise específica, pois a ela se aplicam as regras da denúncia $\left(\S 1^{\circ} \mathrm{e}\right.$ segunda parte do $\S 2^{\circ}$ do art. 234 e caput e parágrafo único do 235) e os procedimentos gerais de fiscalização (arts. 250 a 252), sendo que as pessoas com competência para constarem do polo ativo foram objeto da parte inicial deste capítulo.

${ }^{604}$ Evandro Martins Guerra. Os controles externo e interno da Administração pública. (cit.), 2005. p. 207.

605 “Art. 254. A fiscalização da aplicação de quaisquer recursos repassados pela União, autarquias, fundações instituídas e mantidas pelo poder público e demais órgãos e entidades da administração pública federal mediante convênio, acordo, ajuste ou outros instrumentos congêneres, a estado, ao Distrito Federal, município e a qualquer outra pessoa, física ou jurídica, pública ou privada, será feita pelo Tribunal por meio de levantamentos, auditorias, inspeções, acompanhamentos ou monitoramentos, bem como por ocasião do exame dos processos de tomadas ou prestações de contas da unidade ou entidade transferidora dos recursos. $\S 1^{\circ}$ Para o cumprimento do disposto neste artigo deverão ser verificados, entre outros aspectos, o atingimento dos objetivos acordados, a correção da aplicação dos recursos, a observância às normas legais e regulamentares pertinentes e às cláusulas pactuadas". BRASIL. TCU, Regimento Interno no Tribunal de Contas da União RITCU. Boletim do Tribunal de Contas da União, Brasília, ano 40, n. 1, fev. 2007.
}

${ }^{606}$ Confira-se parte do Acórdão n. 535/2008 - Plenário, Ministro Relator Guilherme Palmeira, ainda que hoje as OS não prestem mais contas ao TCU: "8.Dessa forma, as prestações de contas de ONGs disponíveis neste Tribunal referem-se aos contratos de gestão. Nos demais casos, o modo de atuação do TCU para verificação da regularidade da aplicação dos recursos transferidos opera-se, basicamente, por meio de dois procedimentos: o julgamento de tomadas de contas especiais e as fiscalizações, de iniciativa própria e por solicitação do Congresso Nacional ou decorrentes de representações e denúncias".

${ }^{607}$ Benjamin Zymler. Direito Administrativo e Controle (cit.), 2005. p. 413. 


\subsubsection{Fiscalização}

São instrumentos para exame das transferências voluntárias, a fiscalização por meio de (i) inspeções e auditorias e outros procedimentos adiante descritos, (ii) do acompanhamento pela publicação no Diário Oficial da União da lei relativa ao plano plurianual, da lei de diretrizes orçamentárias, da lei orçamentária anual e da abertura de créditos adicionais - que não serão objetos de análise; e (iii) verificação dos editais de licitação, dos contratos, convênios, acordos, ajustes ou outros instrumentos congêneres.

Se, apesar da previsão constitucional (art. 71, II), as ONGs não podem prestar contas diretamente aos Tribunais de Contas, caberia questionar a respeito do fundamento para poder fiscalizá-las, quando o inciso IV do art. 71 da CF refere-se às auditorias e inspeções sobre as pessoas nele elencadas, inclusive sobre as citadas no inciso II. Este inciso, por sua vez, referese às pessoas obrigadas a ter as suas contas julgadas pelo TCU, das quais foram por ele excluídos os gestores das entidades em exame (art. $2^{\circ}, \S 2^{\circ}$, IN n. 57/2008 do TCU).

Opinamos no sentido da ampla competência fiscalizatória do TCU sobre as entidades privadas em exame, motivo pelo qual versamos acerca da fiscalização neste tópico.

\subsubsection{Levantamento, auditoria, inspeção, acompanhamento e monitoramento}

O Regimento Interno do TCU descreve, na ordem abaixo, os procedimentos de fiscalização das despesas públicas, a nosso ver, aplicáveis ao terceiro setor.

O levantamento dá-se em casos de instituições e sistemas mais complexos, sendo de grande importância para a fiscalização ${ }^{608}$. Consiste no procedimento utilizado pelo Tribunal para (i) conhecer a organização e o funcionamento das instituições que lhe são jurisdicionadas, assim como dos sistemas, programas, projetos e atividades governamentais referentes aos aspectos contábeis, financeiros, orçamentários, operacionais e patrimoniais; (ii) identificar objetos e instrumentos de fiscalização; e (iii) avaliar a viabilidade da realização de fiscalizações (RITCU, art. 238).

A título de exemplo, segundo o Acórdão TCU n. 974/2008 - Plenário, foi inserido levantamento no Plano de Fiscalização para 2007, com a finalidade de formular diagnóstico sobre o funcionamento e o desempenho da função educação, sob o aspecto de sua política, recursos aplicados, funcionamento de seus programas e das organizações públicas atuantes, com

\footnotetext{
${ }^{608}$ Natasha Schmitt Caccia Salinas. Avaliação legislativa no Brasil: um estudo de caso sobre as normas de controle das transferências voluntárias de recursos públicos para entidades do terceiro setor (cit.), 2008. p. 177.
} 
o qual se pretendeu balizar a proposição de auditorias de conformidade, de desempenho operacional ou avaliações de programas, que seriam objeto de planos de fiscalização do TCU ${ }^{609}$.

Já a auditoria é o instrumento de fiscalização utilizado pelo Tribunal para (i) examinar a legalidade e a legitimidade ${ }^{610}$ dos atos de gestão dos responsáveis sujeitos à sua jurisdição quanto aos aspectos contábil, financeiro, orçamentário e patrimonial; (ii) avaliar o desempenho dos órgãos e entidades jurisdicionados, assim como dos sistemas, programas, projetos e atividades governamentais, quanto aos aspectos de economicidade, eficiência e eficácia dos atos praticados $^{611}$; (iii) subsidiar a apreciação dos atos sujeitos a registro (RITCU, art. 239).

Consiste no instrumento por excelência para fiscalizar os repasses de recursos públicos ao terceiro setor, seja por iniciativa própria do TCU, seja em decorrência de representações ou denúncias ${ }^{612}$.

${ }^{609}$ Segundo consta do citado Acórdão, considerou-se oportuno que fossem investigadas as seguintes questões: i) como se caracteriza a função educação em termos de marco legal e arranjos institucionais ii) como se caracteriza a função educação em termos de instrumentalização nos planos e orçamentos públicos; iii) como se caracterizam as subfunções típicas da educação do ponto de vista de sua materialidade, relevância, risco e vínculo de suas ações com o saneamento dos problemas enfrentados em cada uma delas.

${ }^{610}$ A título de exemplo, convém citar o Acórdão Plenário n. 936/2007 relativo à auditoria realizada no Ministério do Meio Ambiente com o objetivo de analisar a legalidade e a legitimidade dos atos de gestão desse Órgão, no que tange aos convênios firmados entres este e organizações não-governamentais (ONGs) e organizações da sociedade civil de interesse público (OSCIPs). Nesta oportunidade, acordaram os Ministros em determinar que o citado Ministério: “[...] 9.3.3. exija a comprovação de que os preços orçados pelos convenentes estão de acordo com o mercado, conforme o art. 27 da IN/STN 01/97 e art. 30 da Lei n ${ }^{\circ}$ 8.666/93; 9.3.4. abstenha-se de remanejar sobra de recursos entre rubricas do plano de trabalho, observando o art. 7o, VII, da IN/STN 01/97; 9.3.5. recuse a apresentação de notas fiscais sem o nome do convenente, emitida após o prazo autorizado ou com discriminação genérica, o que infringe o art. 30 da IN/STN 01/97; [...] 9.3.7. proceda com rigidez na análise da prestação de contas, quanto à não apresentação de documentos ou apresentação de documentos que demonstrem indícios de irregularidades; [...] 9.3.10. atente, nas prestações de contas de convênios, para a existência de notas fiscais que não guardem relação com despesas vinculadas ao cumprimento do objeto, em cumprimento ao art. 7o, XII, da IN/STN 01/97; 9.3.11. verifique, no Cadastro Nacional de Pessoa Jurídica, a descrição da atividade econômica principal dos prestadores de serviços contratados pelas convenentes, cujo serviço prestado divirja do nome da empresa, exigindo justificativa quando isso for comprovado, observando o art. 1o, § 2o, da IN/STN 01/97; 9.3.12. não permita o pagamento de funcionários da convenente com recursos da concedente, o que infringe o art. 8o, II, da IN/STN 01/97; 9.3.13. exija a comprovação da contrapartida e, quando a mesma for oferecida na forma de bens, pessoal e outras despesas de custeio da convenente, exija a especificação de como serão utilizados em benefício do convênio; 9.3.14. abstenha-se de firmar convênio com a finalidade de patrocinar encontros de entidades de classe; [... 9.3.16. observe, quando da análise de propostas de convênios que incluam a aquisição de bens, se estão justificadas as formas como esses serão utilizados e sua adequação à execução do objeto; 9.3.17. quando da celebração de convênios, evite o pagamento de despesas de custeio inerentes a atividades rotineiras do convenente;". Observe-se que neste caso não foi celebrado termo de parceria com as OSCIPs, mas sim convênio e aplicada regras a ele pertinentes, o que tem sido freqüente.

${ }^{611}$ No Acórdão n. 402/2009 (Relatório de Auditoria Operacional), o TCU examinou como se prestava o serviço de saúde dos indígenas e de que forma aplicavam-se os recursos federais repassados, visto que os indicadores do setor não demonstravam bons resultados. Identificou-se, dentre outras irregularidades, que a principal forma de atuação de execução da ação dava-se pelo estabelecimento de convênios com entidades privadas, inclusive ONGs, para contratação de mão-de-obra. Procurou-se, também, examinar os mecanismos de controle social e institucional, tendo constatado que a falta de estrutura do setor comprometia a boa execução dos serviços, sendo praticamente inexistente controle a respeito.

${ }^{612}$ Citam-se os acórdãos que seguem acerca de auditorias realizadas em órgãos e entidades do terceiro setor em 
Dentre os instrumentos disponíveis para fiscalização das transferências voluntárias, destacam-se a auditoria de conformidade e a auditoria operacional.

A auditoria de conformidade tem por foco o exame da legalidade e legitimidade, restando o da economicidade em segundo plano. Por meio dela, o TCU verificará se as exigências legais para a realização das transferências voluntárias foram cumpridas e se estas observâncias conduzem a uma regular e legítima aplicação dos recursos públicos ${ }^{613}$.

Segundo a IN n. 57/2008 do TCU, o exame da conformidade consiste na "análise da legalidade, legitimidade e economicidade da gestão em relação a padrões normativos e operacionais, expressos nas normas e regulamentos aplicáveis, e da capacidade dos controles internos de identificar e corrigir falhas e irregularidades".

A auditoria operacional ${ }^{614}$ surge como inovação para alcance do controle de resultado de projetos relacionados a programas governamentais, ou seja, a "avaliação do desempenho da gestão pública" 615 . Configura-se "ferramenta que lhe permite evoluir no exercício de suas atividades de um controle meramente legal, pautado na formalidade dos atos, para alcançar o controle do resultado da gestão pública", como reflexo da "transição" de administração burocrática para gerencial $^{616}$.

Assim, "foram adicionadas às tradicionais auditorias de conformidade legal novas modalidades de fiscalização, focadas no desempenho do órgão auditado, na economicidade, na eficiência, na eficácia e na efetividade dos atos de Governo" ${ }^{617}$, tornando-se a auditoria operacional tendência crescente, como uma nova prática que "avança sobre os aspectos

razão de repasse de transferências voluntárias, nos quais se concluiu pela quase absoluta ausência de controle e observância das regras específicas acerca de convênios, contratos de repasse e termos de parceria: Acórdão $n$. 1562/2009 - Plenário, Acórdão n. 1933/2007 - Plenário, Acórdão n. 2261/2005 - Plenário, Acórdão n. 2066/2006 - Plenário, Acórdão n. 277/2007 - Plenário e Acórdão n. 1331/2008 - Plenário. No Acórdão n. 1562/2009 - Plenário, o Ministro Relator Augusto Sherman Cavalcanti foi categórico: "É forçoso reconhecer que os achados de auditoria acima relacionados eram de ser esperados na fiscalização realizada. Isso porque ao longo das auditorias de mesma natureza já realizados pelo Tribunal em outros órgãos da Administração Pública Federal os resultados mostraram-se praticamente idênticos. Ou seja, os problemas encontrados no MCT são mera amostra daquilo que acontece na Administração Pública como um todo no tocante à estrutura e às ações de controle relacionadas às transferências voluntárias de recursos federais efetuadas" (p. 53).

${ }^{613}$ Natasha Schmitt Caccia Salinas. Avaliação legislativa no Brasil: um estudo de caso sobre as normas de controle das transferências voluntárias de recursos públicos para entidades do terceiro setor (cit.), 2008. p. 178.

${ }^{614}$ O TCU possui um Manual de Auditoria de Natureza Operacional. Disponível em: http://www.tcu.gov.br. Acesso em: 03 out. 2008.

${ }^{615}$ Luciano Brandão Alves de Sousa. Apreciações sobre o controle externo. Revista de Informação Legislativa, Brasília, ano 43, n. 171, jul./set. 2006, p. 260.

${ }^{616}$ Francisco Taveira Neto. A Evolução da Administração pública e de seus mecanismos de controle na Constituição federal. Revista Zênite de Direito Administrativo e LRF - IDAF, Belo Horizonte. n. 57, abr. 2006. p. 794.

${ }^{617}$ Luciano Brandão Alves de Sousa. Apreciações sobre o controle externo (cit), jul./set. 2006,. p. 263. 
finalísticos da gestão pública",618.

A IN n. 57/2008 delimita o exame do desempenho como a "análise da eficácia, eficiência, efetividade e economicidade da gestão em relação a padrões administrativos e gerenciais, expressos em metas e resultados negociados com a administração superior ou definidos nas leis orçamentárias, e da capacidade dos controles internos de minimizar riscos e evitar falhas e irregularidades".

Esta modalidade de auditoria subdivide-se em auditoria de desempenho operacional e avaliação de programa. A primeira tem por fim examinar a ação governamental sob os aspectos da economicidade, eficiência e eficácia. A segunda, a verificação da efetividade dos programas e projetos governamentais.

A auditoria operacional, bem como a de conformidade, obedece a um plano de ação específico, que pode ser elaborado de forma centralizada ${ }^{619}$ sob a sistemática da Fiscalização de Orientação Centralizada - FOC ${ }^{620}$.

Algumas auditorias realizadas pelo procedimento "FOC" tiveram amplos objetos ${ }^{621}$ de análise dos órgãos parceiros e das entidades privadas sem fins lucrativos receptoras de recursos públicos:

(i) procedimentos de seleção das entidades e celebração de ajustes: para exame se a escolha da "ONG" foi por critérios objetivos, se o Plano de Trabalho contém

${ }^{618}$ Fernando Moutinho Ramalho Bittencourt. A conquista do tempo presente: auditoria operacional e legitimidade das instituições de controle. Revista do Tribunal de Contas da União, Brasília, n. 105, jul./set. 2005, p .61-62

${ }^{619}$ Natasha Schmitt Caccia Salinas. Avaliação legislativa no Brasil: um estudo de caso sobre as normas de controle das transferências voluntárias de recursos públicos para entidades do terceiro setor (cit.), 2008. p. 177-178.

${ }^{620}$ A fiscalização de orientação centralizada - FOC, cujo procedimento inclui preparação centralizada, execução descentralizada e consolidação de resultados, "tem por objetivo avaliar, de forma abrangente e integrada, um tema, programa ou ação de governo, visando a traçar um quadro geral das situações verificadas, identificar irregularidades mais comuns e relevantes e propor aperfeiçoamento nos mecanismos de controle, no arcabouço legal e/ou no modelo de execução de programa/ação, de responsabilidade de um ou de vários órgãos federais" (Acórdão n. 1331/2008 - Plenário). No Acórdão n. 2044/2006, resultado da FOC realizada em "ONGs" pelo TCU, determinou-se ao Ministério do Planejamento, Orçamento e Gestão dar maior transparência na transferência e aplicação de recursos públicos federais, e recomendou-se à Secretaria do Tesouro Nacional, aperfeiçoamento nas normas que regem os convênios. Da realização de auditoria sob o sistema FOC e análise de 28 convênios, foram constatadas algumas das seguintes irregularidades: utilização dos recursos em finalidade diversa, em despesas na permitidas e em data posterior à vigência do convênio, fraude nos pagamentos e documentos comprobatórios das despesas, possível ocorrência de direcionamento da licitação ou licitação montada, movimentação irregular das contas específicas do convênio (Acórdão do TCU $\mathrm{n}$. 2066/2006. Plenário. Relator: Marcos Bemquerer Costa. DOU, 13 nov. 2006 e Acórdão do TCU n. 2261/2005. Plenário. Relator: Guilherme Palmeira. DOU, 03 jan. 2006).

${ }^{621}$ Segundo o Acórdão n. 402/2009 - Plenário, o TCU analisou in loco aldeias indígenas, entrevistou indígenas com a presença de tradutor para averiguar satisfação com relação aos serviços prestados, versou e teceu críticas sobre seus usos e costumes, como o infanticídio, discorreu sobre aprofundado estudo acerca da estrutura do sistema de saúde nacional relativo ao indígena, seus sistemas de controle, ausência de estabelecimento de metas, ausência de controle de resultados, o descumprimento a diversas recomendações de inúmeros órgãos de controle (Congresso Nacional, TCU, Procuradoria Geral da República, Controle Social), dentre outros. 
informações obrigatórias, se houve apreciação do texto das minutas pelos setores técnicos e jurídicos;

(ii) procedimentos de licitação e contratação: para responder às questões se foram observadas as modalidades de licitação pertinentes para aquisição de bens e serviços, se o tratamento aos licitantes foi isonômico, se os preços foram compatíveis com o mercado, se há indício de procedimentos fraudulentos;

(iii) execução física do convênio: com vistas a verificar se o objeto do convênio está sendo integralmente realizado, se os serviços e obras contratados estão sendo cumpridos de acordo com as especificações e exigências legais, se a execução do convênio está sendo acompanhada e fiscalizada pelo órgão público, conselhos de políticas públicas e se os resultados estão sendo analisados por comissão de avaliação e, ainda, se os resultados obtidos estão compatíveis com os propósitos do convênio, contrato de repasse, termo de parceria;

(iv) execução financeira: a fim de verificar se os recursos foram depositados e geridos em conta específica, se a movimentação da conta está 'corretamente' respaldada por documentos 'idôneos' que comprovam a prestação dos serviços/entrega de materiais, se a contrapartida prevista no convênio está sendo 'adequadamente' executada;

(v) prestação de contas: se a análise da prestação de contas pela unidade técnica é feita de modo consistente e tempestiva, se foram adotadas medidas como glosa, rescisão/suspensão do convênio, instauração de contas especial em caso de irregularidade na prestação de contas. ${ }^{622}$

Além de levantamento e auditoria, o TCU poderá realizar inspeção para (i) suprir omissões e lacunas de informações, (ii) esclarecer dúvidas (iii) ou apurar denúncias ou representações quanto à legalidade, legitimidade e economicidade de fatos da administração e de atos administrativos praticados por responsável sujeito à sua jurisdição ${ }^{623}$ (RITCU, art. 240).

O acompanhamento, por sua vez, é o instrumento de fiscalização utilizado para, ao longo de um período predeterminado, (i) examinar a legalidade e a legitimidade dos atos de gestão dos responsáveis sujeitos a sua jurisdição, quanto ao aspecto contábil, financeiro, orçamentário e patrimonial; e (ii) avaliar o desempenho dos órgãos e entidades jurisdicionadas, assim como dos sistemas, programas, projetos e atividades governamentais, quanto aos aspectos de economicidade, eficiência e eficácia dos atos praticados" (art. 241, RITCU). Tem por fim, assim, o mesmo objeto da auditoria, mas dela diferencia-se porque realizado concomitantemente à produção dos atos e execução dos programas.

Trata-se de procedimento de fiscalização efetivado de modo seletivo e concomitante, e pode se dar por intermédio de informações captadas em sistemas informatizados adotados pela Administração, a título de exemplo, o SICONV; editais, extratos de instrumentos de parceria; expedientes e documentos solicitados pelo TCU e visitas técnicas ou participações

\footnotetext{
${ }^{622}$ Todas as questões e expressões foram extraídas do Acórdão n. 1331/2008 - Plenário. Disponível em: $<$ http://www.tcu.gov.br>. Acesso em: 03 out. 2008.

${ }^{623}$ Disponível em: $<$ http://www.tcu.gov.br> $>$. Acesso em: 03 out. 2008.
} 
em eventos promovidos ${ }^{624}$, dentre outros.

Por fim, o monitoramento é o instrumento de fiscalização usado pelo Tribunal para verificar o cumprimento de suas deliberações e os resultados delas advindos (art. 243, RITCU).

Diversamente dos levantamentos e inspeções, as auditorias, os acompanhamentos e monitoramentos são instrumentos que devem obedecer ao Plano de Fiscalização, elaborados pela Presidência do Tribunal. O Plano terá a periodicidade estabelecida em ato normativo do TCU, sendo usualmente semestral ${ }^{625}$.

\subsubsection{Processo de Tomada ou Prestação de Contas}

Como visto, os administradores e responsáveis por recursos públicos sob a jurisdição do Tribunal de Contas devem, em tese, submeter suas contas a julgamento anual por esta Corte, que podem ser prestadas, tomadas (art. 189 do RITCU) ${ }^{626}$ ou seguir o procedimento de TCE.

Há, assim, duas espécies básicas de processos de contas: (i) "as prestações e tomadas de contas ordinárias e extraordinárias, no âmbito das quais o TCU emite um juízo de valor sobre os atos praticados pelos gestores públicos durante um determinado período de tempo"; e (ii) "as tomadas de contas especiais, que visam apurar as responsabilidades e avaliar as repercussões patrimoniais de determinadas ocorrências que ensejaram danos ao erário federal" ${ }^{, 627}$.

Não versaremos sobre a primeira, pois o TCU adotou o entendimento no sentido da obrigatoriedade das entidades sem fins lucrativos receptoras de recursos públicos prestarem contas ao parceiro público ${ }^{628}$ e este, por sua vez, quando assim previsto, deverá (i) apresentar relatório de gestão ${ }^{629}$, (ii) ou englobar em sua própria prestação de contas ao TCU o resultado

\footnotetext{
${ }^{624}$ Francisco Eduardo Carrilho Chaves. Controle externo da gestão pública: a fiscalização pelo legislativo e pelos Tribunais de Contas: teoria e jurisprudência. (cit.), 2007. p. 267.

${ }^{625}$ Ibid., p. 268.

${ }^{626}$ De acordo com a IN n. 57/2008 (art. $1^{\circ}$ ), que regulou a tomada e prestação de contas, a primeira configura-se como o "processo de contas relativo à avaliação da gestão dos responsáveis por unidades jurisdicionadas da administração federal direta, enquanto que a segunda consiste no "processo de contas relativo à avaliação da gestão dos responsáveis por unidades jurisdicionadas da administração federal indireta e por aquelas não classificadas como integrantes da administração federal direta" (g.n.). A distinção entre tomada e prestação de contas, portanto, diz respeito unicamente sobre quem recai o controle de gestão.

${ }^{627}$ Guilherme Henrique de La Rocque Almeida. Controle das transferências financeiras da União. (cit.), $2008 \mathrm{~b}$. p. 186.

${ }^{628}$ Como visto, a majoritária doutrina compartilha deste entendimento. Neste sentido, Guilherme Henrique de La Rocque Almeida. Controle das transferências financeiras da União. (cit.), 2008b. p. 192.
}

${ }^{629}$ A IN n. 57/2008 (art. 1, IV) definiu-o como: “conjunto de documentos, informações e demonstrativos de natureza contábil, financeira, orçamentária, operacional ou patrimonial relativos à gestão dos responsáveis por uma ou mais unidades jurisdicionadas, organizado de forma a possibilitar a visão sistêmica da conformidade e 
das parcerias realizadas ${ }^{630}$, (iii) ou apresentar informações sobre as transferências de recursos públicos realizadas (art. 12, parágrafo único da IN TCU n. 57/2008) ${ }^{631}$. Excepcionalmente, e somente nos casos adiante expostos, caberá a instauração de TCE da entidade privada e, eventualmente, a remessa ao TCU para julgamento.

O julgamento de contas vem sendo tratado como uma aferição do cumprimento de normas legais pelos gestores, reservando às inspeções e auditorias - em especial as “operacionais" - a análise de desempenho da gestão pública ${ }^{632}$. Se as fiscalizações não são corriqueiras, parece-nos que deixar às auditorias o exame da boa gestão de recursos públicos, ao revés de fazê-lo também quando da análise da prestação de contas, poderá contribuir para a continuidade de inúmeras irregularidades constatadas pelo próprio TCU.

\subsubsection{Tomada de Contas Especial}

A TCE é "processo excepcional de natureza administrativa que visa apurar responsabilidade por omissão ou irregularidade no dever de prestar contas ou por danos causados ao erário"633. Configura-se como obrigação de fazer não-personalíssima do gestor de recursos públicos.

O TCU se utiliza desse procedimento para julgar as contas das entidades do terceiro setor faltosas.

Segundo Jorge Ulisses Jacoby Fernandes, a CF/88 não dispõe sobre a TCE como tipo de processo autônomo, apenas "indicando a necessidade de um procedimento específico para apurar prejuízos causados ao erário" ${ }^{\circ 34}$.

Passamos ao exame do conteúdo de diversos diplomas legais aplicáveis na esfera federal acerca do TCE.

O art. $8^{\circ}$ da Lei Orgânica e o art. 197 do RITCU preveem as hipóteses nas quais

do desempenho desta gestão".

630 “Art. $1[\ldots] \S 2^{\circ}$ Os estados, o Distrito Federal, os municípios e as pessoas físicas ou entidades privadas, quando beneficiários de transferência voluntária de recursos federais sob qualquer forma, responderão perante o órgão ou entidade repassador pela boa e regular aplicação desses recursos, apresentando os documentos, informações e demonstrativos necessários à composição dos relatórios de gestão e dos processos de contas dos responsáveis por essas unidades jurisdicionadas”. (IN n. 57/2008)

631 “Ademais, prestar informações nas contas anuais sobre transferências voluntárias é agora exigência do art. 12, parágrafo único, in fine, da IN TCU no 57/2008." Cf. Acórdão TCU n. 2.540/09 - Primeira Câmara, Ministro Relator Walton Alencar Rodrigues. DOU 22/05/2009.

${ }^{632}$ Benjamin Zymler. Direito Administrativo e Controle (cit.), 2005. p. 415.

${ }^{633}$ Jorge Ulisses Jacoby Fernandes. Tomada de Contas Especial: processo e procedimento nos Tribunais de Contas e na Administração Pública. (cit.), 2005a. p. 31.

${ }^{634}$ Ibid., p. 28. 
deverá ser instaurada a TCE a fim de apurar fatos, quantificar danos e identificar responsáveis. Desta forma, quando da realização de fiscalização, dentre outras, será instaurada a TCE se verificada qualquer das seguintes irregularidades: (i) omissão no dever de prestar $\operatorname{contas}^{635}$, (ii) não comprovação de aplicação dos recursos repassados pela União, (iii) ocorrência de desfalque ou desvio de dinheiros, bens ou valores públicos e (iv) prática de qualquer ato ilegal, ilegítimo ou antieconômico do qual resulte dano ao erário.

A TCE somente será iniciada se exauridas as tentativas de recebimento da prestação de contas ou ressarcimento dos valores recebidos ${ }^{636}$. A despeito da ausência de dano ao erário, a simples omissão ao dever de prestar contas provoca a instauração da TCE pelo órgão público parceiro. Este encaminhará ao TCU, se verificado o valor de alçada estipulado.

A Lei Federal n. 8.666/93, no art. 116, $\S 6^{\circ}$, aplicável subsidiariamente aos convênios e contratos de repasse segundo o art. 42 da IN/STN 01/97 637 e art. 56, §2 ${ }^{\circ}$ da PI n. 127/08 previu que, extinto o convênio, acordo ou ajuste, serão devolvidos os valores remanescentes em 30 dias, sob pena de imediata instauração de TCE pela autoridade competente ou titular dos recursos.

Ademais, se da rescisão de convênios e contratos de repasse (a nosso ver, de qualquer parceria) resultar dano ao erário, será caso de instauração de TCE (art. 62, PI n. 127/08).

Em diversos momentos, a PI n. 127/08 versou sobre as hipóteses de instauração da TCE, em muito semelhante à regulação editada pelo TCU: (i) quando a prestação de contas não for aprovada; (ii) em decorrência da não utilização total ou parcial da contrapartida pactuada; (iii) não aplicação ou não devolução dos rendimentos de aplicação financeira dos recursos recebidos; (iv) não devolução de eventual saldo; e (v) desvio de finalidade (art. 63).

No Manual de Convênios e Outros Repasses, o TCU exemplificou os casos de instauração de TCE relativo aos convênios ou contratos de repasse: (i) rejeição parcial ou total das contas apresentadas pelo gestor ao órgão repassador dos recursos - motivada pela

\footnotetext{
${ }^{635}$ A doutrina e a jurisprudência dividem-se no que tange a irregularidade pela omissão na prestação de contas. Se, para alguns, a simples omissão enseja a declaração de irregularidade, para outros, se apresentada a destempo, estará descaracterizada a irregularidade e as contas serão julgadas regulares com ressalva. Parecenos oportuno verificar as causas da omissão antes do julgamento pela irregularidade, como a força maior ou caso fortuito, quando se tornam iliquidáveis e o TCU indica o arquivamento do processo (súmula 03). Na esteira de Jorge Ulisses Jacoby Fernandes, nestes casos nem mesmo caberia a instauração de TCE. Cf. Jorge Ulisses Jacoby Fernandes. Tomada de Contas Especial: processo e procedimento nos Tribunais de Contas e na Administração Pública. (cit.), 2005a. p. 121.

${ }^{636}$ Natasha Schmitt Caccia Salinas. Avaliação legislativa no Brasil: um estudo de caso sobre as normas de controle das transferências voluntárias de recursos públicos para entidades do terceiro setor (cit.), 2008. p. 141.

${ }^{637}$ BRASIL. TCU. Convênios e outros repasses, 2008, p. 57. Acórdão n. 1562/2009 - Plenário. Min. Relator: Augusto Sherman Cavalcanti. DOU 17/07/09 Disponível em: <http//:www.tcu.gov.br>. Acesso em: 29 jul. 2009.
} 
constatação de superfaturamento, de sobrepreço, de não execução do objeto, de ausência de nexo entre as despesas realizadas e o objeto pactuado, de desvio de objeto, dentre outras; (ii) irregularidades detectadas por ação dos órgãos fiscalizadores; e (iii) denúncias de irregularidades em convênios ou repasses apresentadas por cidadãos ou veiculadas nos meios de comunicação, as quais, apuradas, sejam comprovadas ${ }^{638}$.

São quatro os tipos de TCE, segundo classificação de Jorge Ulisses Jacoby Fernandes $^{639}$ : (i) simplificada: se inferior ao valor de alçada estipulado pelo TCU (R\$ 23.000,00, segundo o art. 11 da IN n. 56/2007), será a ele remetida em conjunto com as contas anuais, devendo a própria Administração decidir a respeito; (ii) completa: todas as de valor da alçada; (iii) convertida: decorre da conversão de inspeção ou auditoria, quando verificado dano ao erário ou omissão de prestação de contas e (iv) ex-officio: por determinação do TCU, ao constatar desvio de conduta ou ilegalidade - inclusive após aprovação da prestação de contas da entidade pelo órgão parceiro ${ }^{640}$. Em face da dinâmica do TCU, somente as duas últimas hipóteses aplicar-se-ão ao terceiro setor.

Para o citado autor, a TCE possui duas fases, salvo exceções: (i) interna, como processo da Administração, visa determinar a regularidade ou não na guarda e aplicação de recursos públicos e (ii) externa, como processo do TCU. Diante de irregularidade, tem por fim o julgamento da conduta do agente ${ }^{641}$.

Acerca do rito, a autoridade administrativa competente, ao tomar ciência da ocorrência das hipóteses indicadas, deverá espontaneamente providenciar a instauração de TCE, sob pena de responsabilidade solidária. O Tribunal de Contas poderá determinar a instauração da TCE, fixando prazo para cumprimento dessa decisão, caso verifique inércia na atuação da autoridade administrativa. A Corte poderá, também, converter processo de fiscalização em TCE, ficando dispensada parcialmente de seguir as mesmas exigências dos casos de instauração (art. 198, parágrafo único, RITCU).

São elementos essenciais ao processo de TCE (IN TCU 56/2007): a) ficha de

\footnotetext{
${ }^{638}$ BRASIL. TCU. Convênios e outros repasses, 2008, p. 57. Acórdão n. 1562/2009.

639 Jorge Ulisses Jacoby Fernandes. Tomada de Contas Especial: processo e procedimento nos Tribunais de Contas e na Administração Pública. (cit.), 2005a. p. 39-43.

${ }^{640} \mathrm{Na}$ esteira de Ubiratan Aguiar, Ministro do TCU: "A prestação de contas da regular aplicação de recursos de convênio deve ser apresentada ao órgão ou entidade concedente, a quem incumbe apreciá-la, e não ao Tribunal de Contas da União [...]. No entanto, a aprovação desta prestação de contas não gera para o convenente prova irrefutável da regular aplicação dos recursos. Pode, dessa forma, o concedente ou o próprio TCU, em fiscalizações, ao detectar qualquer irregularidade na aplicação desses recursos, instaurar a correspondente TCE". (cf. Ubiratan Aguiar et al. Convênios e tomadas de contas especiais: manual prático.(cit.), 2007. p. 111).

${ }^{641}$ Jorge Ulisses Jacoby Fernandes. Tomada de Contas Especial: processo e procedimento nos Tribunais de Contas e na Administração Pública. (cit.), 2005a. p. 32.
} 
qualificação do responsável; b) demonstrativo financeiro do débito; c) cópia integral do processo de transferência de recursos, juntamente com a prestação de contas, quando for o caso; d) cópia do relatório de comissão de sindicância ou de inquérito, acompanhado de cópia dos documentos que caracterizam a responsabilidade apurada; e) cópia das notificações de cobrança expedidas; f) cópia da notificação da entidade beneficiária, no caso de omissão no dever de prestar contas de recursos repassados mediante convênio, contrato de repasse ou instrumento congênere; g) relatório do tomador de contas (pode ser o responsável pela gestão dos recursos ou outro agente designado para tomar as contas); h) relatório e o certificado de auditoria (emitidos pelo controle interno); i) pronunciamento ministerial; e g) outros elementos que contribuam para caracterização do dano e da responsabilidade.

O art. 197, $\S 3^{\circ}$ do RITCU dispensa da instauração de TCE a "ocorrência de perda, extravio ou outra irregularidade sem que se caracterize a má-fé de quem lhe deu causa, se o dano for imediatamente ressarcido", devendo a autoridade administrativa competente, em sua tomada ou prestação de contas ordinária, comunicar o fato ao Tribunal.

A decisão em processo de prestação ou de tomada de contas ou TCE pode ser preliminar, definitiva ou terminativa (RITCU, art. 201). Na decisão preliminar pela qual "o relator ou o Tribunal, antes de pronunciar-se quanto ao mérito das contas, resolve sobrestar o julgamento, ordenar a citação ou a audiência dos responsáveis, rejeitar as alegações de defesa e fixar novo e improrrogável prazo para recolhimento do débito ou, ainda, determinar outras diligências necessárias ao saneamento do processo". A decisão definitiva consiste naquela "pela qual o Tribunal julga as contas regulares, regulares com ressalva ou irregulares" e a terminativa, por sua vez, foi delimitada como "a decisão pela qual o Tribunal ordena o trancamento das contas que forem consideradas iliquidáveis, ou determina o seu arquivamento pela ausência de pressupostos de constituição e de desenvolvimento válido e regular do processo ou por racionalização administrativa e economia processual [...]”.

As contas ordinariamente prestadas e objeto de Processo de Contas poderão ser julgadas regulares, regulares com ressalva, ou irregulares, a depender do caso (art. 15, Lei Orgânica do TCU).

Segundo o art. 16 da Lei Orgânica do TCU, as contas serão julgadas regulares "quando expressarem, de forma clara e objetiva, a exatidão dos demonstrativos contábeis, a legalidade, a legitimidade e a economicidade dos atos de gestão do responsável". Neste caso, a publicação do acórdão no DOU constituirá certificado de quitação plena aos responsáveis.

Serão julgadas regulares com ressalva "quando evidenciarem impropriedade ou 


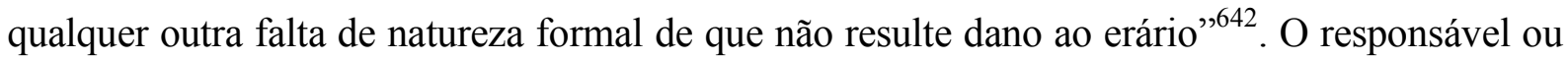
sucessor receberá quitação com a determinação de adoção de medidas necessárias a correção das impropriedades ou faltas identificadas, de modo a prevenir outras semelhantes ${ }^{643}$.

Por fim, julgará irregulares se comprovada qualquer das seguintes ocorrências: (a) omissão no dever de prestar contas; (b) prática de ato de gestão ilegal, ilegítimo, antieconômico, ou infração à norma legal ou regulamentar de natureza contábil, financeira, orçamentária, operacional ou patrimonial; (c) dano ao erário decorrente de ato de gestão ilegítimo ou antieconômico; (d) desfalque ou desvio de dinheiros, bens ou valores públicos.

Os efeitos destas decisões sobre as entidades do terceiro setor e seus dirigentes serão objeto de análise em tópico específico.

\subsubsection{Procedimentos especiais}

Dentre os procedimentos especiais, serão examinadas a denúncia e a consulta. $\mathrm{O}$ procedimento de registro de atos não integrará o estudo, pois, já se disse, mostra-se inaplicável aos casos de contratação de pessoal, aposentadoria e pensão relativas às entidades do terceiro setor.

\subsubsection{Denúncia e consulta}

A Lei Orgânica do TCU (art. 1', XVI) estabelece a atribuição deste para "decidir sobre denúncia que lhe seja encaminhada por qualquer cidadão, partido político, associação ou sindicato, na forma prevista nos arts. 53 a 55 desta lei”, reproduzindo o texto constitucional

\footnotetext{
${ }^{642} \mathrm{O}$ TCU, quando ainda se atribuía a competência para examinar contas das OSs, julgou regulares com ressalva as contas prestadas para que

“9.3.1. especifique, em suas prestações de contas referentes aos contratos de gestão pactuados, os atos de nomeação, designação e exoneração, bem como os períodos de gestão das autoridades arroladas, conforme exige o art. 13, incisos III e IV da IN/TCU n. 47/2004;

9.3.4. contabilize as receitas e despesas de modo a que fiquem identificadas todas aquelas que tenham, respectivamente, origem e suporte em repasses provenientes da União, evidenciando, nas próximas prestações de contas, os excedentes financeiros acumulados desde 2002;

9.3.5. somente realize gastos utilizando recursos provenientes de contratos de gestão para fazer frente às despesas necessárias a implementação das ações previstas no ajuste firmado;

9.3.6. faça constar, nos respectivos processos, as justificativas sobre a necessidade da contratação de pessoal efetivada com utilização de recursos públicos e a motivação para a escolha dos profissionais que vieram a ser selecionados, em atenção aos arts. $2^{\circ}$ e $3^{\circ}$ da Norma Complementar/CGEE n. 001/2002 - Regulamento de Compras, atentando para os requisitos legais para a contratação de profissionais de notória especialização". Acórdão TCU n. 2640/2008 - Primeira Câmara, DOU 20/08/2008

${ }^{643}$ Francisco Eduardo Carrilho Chaves. Controle externo da gestão pública: a fiscalização pelo legislativo e pelos Tribunais de contas: teoria e jurisprudência. (cit.), 2007. p. 242..
} 
(art. 74, $\S 2^{\circ}$ ). Neste sentido, o RITCU (art. 234) disciplinou a matéria, estabelecendo a legitimidade daquelas pessoas como partes legítimas para denunciar irregularidades ou ilegalidades perante o TCU. A relação é numerus clausus.

Salvo nos casos e atos de sigilo, reunidas as provas indicadoras de irregularidade ou ilegalidade, dar-se-á andamento ao processo (art. 234 do RITCU), assegurando-se aos acusados oportunidade de ampla defesa, com observância, no que couber, dos procedimentos prescritos nos arts. 250 a 252 do RITCU, a serem objeto do tópico seguinte.

A denúncia deverá ser sobre matéria de competência do Tribunal e referir-se ao administrador ou responsável sujeito à sua jurisdição, sendo de rigor conter o nome legível do denunciante, sua qualificação e endereço, e estar acompanhada de indício concernente à irregularidade ou ilegalidade denunciada, sob pena de seu não conhecimento (art. 235, RITCU). A denúncia anônima ou oral ${ }^{644}$ não será conhecida sem prejuízo do TCU examinar os fatos e atos apontados.

O denunciante não se sujeitará a nenhuma sanção administrativa, cível ou penal em decorrência da denúncia, salvo se comprovada má-fé (art. 236, § $2^{\circ}$, do RITCU).

As entidades do terceiro setor poderão denunciar ou ser denunciadas ao TCU a respeito da gestão de recursos públicos recebidos em razão de parcerias celebradas.

A consulta ao TCU, por sua vez, segue procedimento específico, visando decidir sobre questão formulada por autoridade competente, a respeito de dúvida suscitada na aplicação de dispositivos legais e regulamentares concernentes a matéria de sua competência.

Não há previsão de as entidades ou pessoas privadas receptoras de recursos públicos consultarem o TCU (art. 264 do RITCU), razão pela qual não será objeto de maiores explanações.

Registramos a impertinência desta vedação, pois, em que pese existir competência do TCU para fiscalizar aquelas entidades acerca de sua observância de preceitos legais e regulamentares sobre elas incidentes, estas não podem submeter-lhe dúvidas a respeito. Se o direito público passa a ser-lhes aplicado, ainda que parcialmente, por força dos recursos recebidos, não há fundamento para não poderem ter suas questões legais dirimidas - até mesmo para melhor cumpri-las.

\footnotetext{
${ }^{644}$ Francisco Eduardo Carrilho Chaves. Controle externo da gestão pública: a fiscalização pelo legislativo e pelos Tribunais de contas: teoria e jurisprudência. (cit.), 2007. p. 262.
} 


\section{1 Considerações preliminares}

Uma vez contextualizado o tema desta dissertação, identificadas as atribuições dos Tribunais de Contas para fiscalização das entidades do terceiro setor parceiras do Estado, bem como os objetos de controle previstos na legislação específica e os procedimentos para sua realização, apresenta-se relevante a análise dos principais efeitos resultantes de sua atuação.

Para fins didáticos, os efeitos foram divididos em diretos e indiretos. Os primeiros decorrem do exercício da atribuição controladora do TCU, consistindo naquelas repercussões que a tomada de decisões, acórdãos ou a instauração de TCE acarretam diretamente, e por sua expressa determinação sobre o patrimônio, a atuação da entidade do terceiro setor ou de seus administradores. Os segundos dependem do alvedrio de terceiros para sua realização, como “externalidades" em outras esferas das decisões daquele Tribunal.

Embora o TCU posicione-se contrário à obrigatoriedade de as ONGs lhe prestarem contas diretamente, sobre as mesmas incidem quase todos os efeitos aplicáveis aos administradores públicos, ao terem-nas julgadas irregulares.

\section{2 Efeitos diretos}

\subsubsection{Medidas cautelares}

\subsubsection{Aplicabilidade}

Dentre as competências do TCU, encontra-se a possibilidade de adotar as medidas cautelares (art. 1, XVII, RITCU), enquadradas como urgentes e de tramitação preferencial (art. 159, RITCU).

As medidas cautelares poderão incidir sobre os administradores das entidades do terceiro setor, por serem enquadráveis como responsáveis por recursos públicos, expressão ampla a abarcar todos os gestores destes, e assim prevista em Lei (arts. 273 a 276 do RITCU). 


\subsubsection{Natureza}

Os artigos 273 a 277 do Título VIII, do RITCU, denominado "Medidas Cautelares", não as definiram como sanções, estas elencadas nos artigos 266 a 272. Neste sentido, o artigo 274, do RITCU, ao versar sobre a medida cautelar de indisponibilidade de bens, distingue-a explicitamente da sanção prevista no artigo 270 (inabilitação de responsável para o cargo em comissão), ratificando o entendimento pela diversidade legal de suas naturezas.

Alguns autores, no entanto, enquadram as medidas cautelares como sanção ou como de caráter sancionador.

A título de exemplo, Márcia Semer ${ }^{645}$, diversamente de Márcia Pelegrini ${ }^{646}$, posicionase no sentido da natureza sancionatória da medida cautelar denominada afastamento temporário do responsável, bem como da decretação de indisponibilidade de bens ${ }^{647}$ e do arresto de bens ${ }^{648}$.

\subsubsection{Suspensão de atos}

Para os casos de urgência, de fundado receio de grave lesão ao erário ou a direito alheio ou de risco de ineficácia da decisão de mérito, o RITCU previu a possibilidade de o TCU, mediante provocação ou de ofício, adotar medida cautelar, com ou sem a prévia oitiva da parte, determinando, entre outras providências, a suspensão do ato ou do procedimento impugnado, até decidir sobre o mérito da questão suscitada (art. 276).

Para Antonio Silvio Magalhães Junior, trata-se de medida excepcional, pois, via de regra, a sustação deve ser precedida de aplicação de prazo para saneamento, nos termos do art. 71, IX da CF/88 $8^{649}$.

São exemplos da incidência desta competência do TCU sobre as entidades do terceiro setor a suspensão cautelar de processo seletivo destinado à contratação de pessoal por OS, determinando a oitiva dos responsáveis e a fixação de prazo para sua anulação, com

\footnotetext{
${ }^{645}$ Márcia Maria Barreto Fernandes Semer. Competências constitucionais do Tribunal de Contas. (cit.), 2000. p. 108.

${ }^{646}$ Márcia Pelegrini. A Competência Sancionatória do Tribunal de Contas no exercício da função controladora: contornos constitucionais. (cit.), 2008, p. 142.

${ }^{647}$ Márcia Maria Barreto Fernandes Semer. Competências constitucionais do Tribunal de Contas. (cit.), 2000. p. 109.

${ }^{648}$ Ibid., p. $107-108$.

${ }^{649}$ Antonio Silvio Magalhães Junior. O controle externo da Administração pública pelo Tribunal de contas. (cit.), 2005. p. 197.
} 
fundamento no art. 45 da LOTCU ${ }^{650}$; a suspensão por uma OSCIP de todos os atos relativos a termo de parceria, salvo os referentes a eventos já iniciados ${ }^{651}$; e a suspensão cautelar de pregão eletrônico de OS em face de irregularidades constatadas ${ }^{652}$.

\subsubsection{Afastamento temporário}

O TCU também poderá, no início ou no curso de apuração, cautelarmente, obrigar o afastamento temporário de responsável, por meio de determinação ao superior hierárquico deste $^{653}$, sob pena de responsabilidade solidária (art. 44, § 1, LOTCU).

Para tanto, deverá existir indício suficiente de que, prosseguindo no exercício de suas funções, o responsável possa, conjugada ou individualmente (i) retardar ou dificultar a realização de auditoria ou inspeção, (ii) causar novos danos ao erário ou (ii) inviabilizar o seu ressarcimento (art. 44, LOTCU e art. 273, RITCU).

A despeito de executada por intermédio de órgão público, trata-se de medida a ser determinada pelo TCU, cujo prazo não foi definido em Lei e deve ser pelo período julgado por elas necessário.

De todo modo, trata-se de medida pouco aplicada, segundo Benjamin Zymler, por não configurar-se praxe a oposição a atividade fiscalizatória do TCU.

Vez que a Lei utiliza-se da expressão responsáveis, opinamos no sentido da aplicabilidade da medida cautelar em comento sobre os representantes das ONGs gestoras de recursos públicos.

\subsubsection{Indisponibilidade de bens}

Poderá o Tribunal, diante das mesmas circunstâncias do afastamento, decretar, diretamente, a indisponibilidade de bens ${ }^{654}$ do responsável, em montante suficiente para

\footnotetext{
${ }^{650}$ BRASIL. TCU. Acórdão n. 1111/2008-Plenário. Disponível em: http://www.tcu.gov.br. Acesso em: 20 ago. 2009.

${ }^{651}$ BRASIL. TCU. Acórdão n. 1386-2009 - Plenário. Min. Relator André Luís de Carvalho. p. 02 Disponível em: $<$ http//:www.tcu.gov.br>. Acesso em: 29/07/2009.

${ }^{652}$ Neste sentido, Acórdão n. 1270/2007 e o Acórdão TCU n. 808/2008-Plenário, tendo como Ministro relator Augusto Sherman Cavalcanti.

${ }^{653}$ Benjamin Zymler. Direito Administrativo e Controle. (cit.), 2005. p. 464.

${ }^{654}$ A Lei das OSCIPS (art. 13) previu que também a Advocacia Geral da União e o Ministério Público podem pleitear em juízo a decretação de indisponibilidade dos bens da entidade e o seqüestro de bens de seus dirigentes, do agente público e de terceiro que tenha causado prejuízo ao erário, além das demais sanções cabíveis. No Acórdão TCU n. 387/2009-Plenário, da lavra do Ministro Aroldo Cedraz, constou decisão para
} 
garantir o ressarcimento dos danos em apuração e por prazo não superior a um ano (art. $44, \S$ 2, LOTCU e art. 274, RITCU).

Trata-se de medida cautelar passível de ser decretada em procedimentos fiscalizatórios e em processo de $\operatorname{contas}^{655}$, já aplicada aos dirigentes de entidades do terceiro setor, na condição de gestores de recursos públicos ${ }^{656}$.

\subsubsection{Arresto de bens}

Cabe citar, ainda, o arresto dos bens do responsável julgado em débito ${ }^{657}$, a fim de assegurar o ressarcimento do dano ao término do processo. Configura-se medida a ser solicitada pelo Tribunal de Contas à Advocacia-Geral da União ou a dirigentes de entidades jurisdicionadas (art. 61, LOTCU e art. 275 do RITCU). A despeito de constar na Lei a expressão "solicitar", entendemos de rigor ser entendida como "determinar", não cabendo escolha acerca da adoção do pleito do TCU junto ao Poder Judiciário ${ }^{658}$. Este, por sua vez, deve ouvir o TCU antes da decisão de liberação dos bens arrestados e sua restituição (art. 61, LOTCU).

Também é medida aplicável sobre os gestores privados de recursos públicos porque considerados por eles responsáveis.

"9.6 determinar a 5 Secex que promova o levantamento de bens de propriedade da Anara e do Sr. Bruno Costa de Albuquerque Maranhão, com indicação daqueles que, em razão do valor, possam ter sua indisponibilidade decretada para assegurar o ressarcimento dos débitos eventualmente imputados àqueles responsáveis, em consonância com o disposto no art. 44, § $2^{\circ}$, da Lei 8.443/1992”.

${ }^{655}$ Decisão n. 26/2001-Plenário.

${ }^{656}$ O TCU proferiu a seguinte recomendação, ao versar sobre transferências voluntárias mediante contratos de repasse e convênio celebrado com ONG: "9.2.3. em caso de irregularidades em que o dano ao erário esteja perfeitamente demonstrado, seja verificada a viabilidade de adoção de medida cautelar visando a indisponibilidade de bens dos responsáveis, inclusive e principalmente das empresas envolvidas, para assegurar o ressarcimento aos cofres públicos em caso de condenação pelo TCU” (cf. Acordão n. 641/2007 Plenário Ministro Relator Benjamin Zymler).

${ }^{657}$ Vale lembrar que Lei das OSs previu que: "Art. 10. Sem prejuízo da medida a que se refere o artigo anterior, quando assim exigir a gravidade dos fatos ou o interesse público, havendo indícios fundados de malversação de bens ou recursos de origem pública, os responsáveis pela fiscalização representarão ao Ministério Público, à Advocacia-Geral da União ou à Procuradoria da entidade para que requeira ao juízo competente a decretação da indisponibilidade dos bens da entidade e o seqüestro dos bens dos seus dirigentes, bem como de agente público ou terceiro, que possam ter enriquecido ilicitamente ou causado dano ao patrimônio público. $\S 1 \mathrm{O}$ pedido de seqüestro será processado de acordo com o disposto nos arts. 822 e 825 do Código de Processo Civil. § 2 Quando for o caso, o pedido incluirá a investigação, o exame e o bloqueio de bens, contas bancárias e aplicações mantidas pelo demandado no País e no exterior, nos termos da lei e dos tratados internacionais".

${ }^{658}$ Márcia Maria Barreto Fernandes Semer. Competências constitucionais do Tribunal de Contas. (cit.), 2000. p. 110. 


\subsubsection{Sanções}

\subsubsection{Aplicabilidade}

Consoante exposto inicialmente neste trabalho, o TCU foi constitucionalmente dotado da seguinte atribuição: "aplicar aos responsáveis, em caso de ilegalidade de despesa ou irregularidade de contas, as sanções previstas em lei, o que estabelecerá, entre outras cominações, multa proporcional ao dano causado" (art. 71, VIII da CF/88).

A aplicação de sanções pelo $\mathrm{TCU}^{659}$ sobre os dirigentes das entidades do terceiro setor encontra respaldo na expressão constitucional responsáveis, sem prejuízo do dever de ressarcimento de quantia relativa ao dano causado ${ }^{660}$.

Para Márcia Pelegrini, o texto constitucional comporta interpretações divergentes em pelo menos dois aspectos, a saber: no que se refere à possibilidade de o legislador infra-legal criar a pena de multa quando não há dano ao erário e quanto à possibilidade de estabelecer sanções, inclusive multa, sobre atos não relacionados à ilegalidade de despesas e à irregularidade de $\operatorname{contas}^{661}$.

O Supremo Tribunal Federal não questiona a autorização constitucional para estabelecimento de multas coercitivas sem relação aos vetores "irregularidade das contas" e "ilegalidade das despesas" 662 .

Serão examinadas algumas sanções previstas em lei e assim por ela consideradas aplicáveis ao terceiro setor pelo TCU.

\footnotetext{
${ }^{659}$ Para Márcia Pelegrini, “O direito sancionador é um só. [...]. As sanções aplicadas pelo Tribunal de Contas se enquadram na espécie de sanção administrativa, porque são aplicadas por autoridade administrativa, porém no exercício da função controladora, que embora revele a natureza administrativa de seus atos, não é a função administrativa propriamente dita, de executar a lei de ofício, mas de fiscalizar a adequada execução pelos órgãos dos Poderes do Estado e de todos aqueles que estão sob sua jurisdição. [...] as decisões do Tribunal de Contas que implicam no estabelecimento de sanções, são de natureza administrativa". A autora esclarece: "As sanções caberão apenas nas modalidades concomitante, quando constatada a consumação de despesa irregular e, a posteriori, cuja legalidade da despesa é apreciada apenas quando já efetuada, cabendo em muitas situações apenas providenciar a punição dos culpados." (Márcia Pelegrini. A Competência Sancionatória do Tribunal de Contas no exercício da função controladora: contornos constitucionais. [cit.], 2008, p. 109-111.)

${ }^{660}$ Para Francisco Eduardo Carrilho Chaves, “a condenação em débito, que acarreta a obrigação de restituílo, não é sanção. Trata-se apenas da recomposição do erário ou dos cofres de fundo ou de entidade da administração indireta, decorrente de responsabilização civil." (g.a.). Controle externo da gestão pública: a fiscalização pelo legislativo e pelos Tribunais de contas: teoria e jurisprudência. (cit.), 2007. p. 283.

661 Márcia Pelegrini. A Competência Sancionatória do Tribunal de Contas no exercício da função controladora: contornos constitucionais. (cit.), 2008, p. 131.

${ }^{662}$ BRASIL. STF. RE n. 190.985 - SC. Relator Min. Néri da Silveira, 14/02/1996. DJ 24/08/2001. Disponível em: www.stf.gov.br. Acesso em: 20 out. 2009.
} 


\subsubsection{Multa}

A LOTCU previu a aplicação de pena de multa (i) em face da existência de dano, quando com ele deverá guardar proporcionalidade; (ii) para situações de ausência de dano (art. 58, I), como contas julgadas irregulares mas sem débito; e (iii) situações não enquadráveis como de irregularidade de contas ou ilegalidade de despesas (incisos IV a VII e parágrafo $1^{\circ}$ )

Hodiernamente, a pessoa física ou jurídica julgada em débito poderá responder pelo montante de até cem por cento do valor atualizado do dano causado ao erário (art. 57, LOTCU).

Além desta, segundo o art. 58 do LOTCU, o Tribunal poderá ${ }^{663}$ aplicar ao gestor de recursos públicos ${ }^{664}$ percentual de valor de multa nele estabelecido: (i) quando tiver suas contas julgadas irregulares sem resultar em débito; (ii) por ato praticado com grave infração à norma legal ou regulamentar de natureza contábil, financeira, orçamentária, operacional e patrimonial $^{665}$; (iii) por ato de gestão ilegítimo ou antieconômico com injustificado dano ao erário; (iv) pelo não atendimento, no prazo fixado, sem causa justificada, a diligência do Relator ou a decisão do Tribunal; (v) em razão da obstrução ao livre exercício das inspeções e auditorias determinadas; (vi) pela sonegação de processo, documento ou informação, em inspeções ou auditorias realizadas pelo Tribunal; (vii) por motivo de reincidência no descumprimento de determinação do Tribunal. O descumprimento de decisão do TCU também ensejará aplicação de multa no valor equivalente à prevista no caput do art. 58, salvo motivo justificado (art. 58, $\S 1^{\circ}$ ).

Em atenção ao $\S 3^{\circ}$ do art. 58 (LOTCU), o RITCU (art. 268) dispôs sobre a gradação da multa prevista no caput daquele artigo, em função da gravidade da infração. Se a multa deve ser

\footnotetext{
${ }^{663}$ Lembra Francisco Eduardo Carrilho Chaves que, por força do art. 19 da LOTCU, “é obrigatório aplicar multa a responsável por contas em que não existe débito, mas que merecem julgamento pela irregularidade, em razão de:

(i) omissão no dever de prestar contas;

(ii) prática de ato de gestão ilegal, ilegítimo, antieconômico, ou infração à norma legal ou regulamentar de natureza contábil, financeira, orçamentária, operacional ou patrimonial; e

(iii) dano ao erário decorrente de ato de gestão ilegítimo ou antieconômico".
}

Controle externo da gestão pública: a fiscalização pelo legislativo e pelos Tribunais de contas: teoria e jurisprudência. (cit.), 2007. p. 286.

664 A multa prevista no art. 58 da LOTCU aplica-se somente aos casos de gestão de recursos públicos. Cf. Acórdão TCU n. 104/2009 - Plenário, Ministro Aroldo Cedraz.

${ }^{665}$ Cf. Acórdão n. 387/2009-Plenário, Ministro Aroldo Cedraz, no qual se aplicou multa de R\$ 4.000,00 em razão das irregularidades relativas a celebração, execução e prestação de contas de convênio. 
proporcional ao dano causado, ao que parece, não poderá ser em valor superior a ele ${ }^{666}$.

Para Francisco Eduardo Carrilho Chaves "as multas são cabíveis pelo conjunto de atos da gestão julgada pelo Tribunal. Ou seja, decorrem da má gestão do responsável como um todo" ${ }^{\prime 667}$ (grifos do autor). Assim, esta sanção poderá ser aplicada em processo de fiscalização, sem ensejar prejulgamento das contas ordinárias da unidade jurisdicionada, devendo o fato ser considerado no contexto dos demais atos de gestão do período (art. 250 e 251 do RITCU).

A condenação pela irregularidade das contas também poderá ensejar a restituição dos valores devidos, corrigidos monetariamente e com incidência de juros ${ }^{668}$, além de multa.

Assim, com base na conjugação da parte final do inciso II e do conteúdo do inciso VIII do art. 71 da CF/88, “decidindo o Tribunal que alguém deu causa a perda ou extravio de dinheiro ou quaisquer bens públicos, profere determinação não apenas no sentido de que restitua o valor correspondente, como também ainda lhe aplica as outras sanções previstas para a espécie em lei específica, inclusive multa proporcional ao valor do prejuízo causado ao Erário" ${ }^{669}$.

Embora a legislação relativa ao terceiro setor tenha por foco os resultados da parceria, para Sebastião Baptista Affonso "ainda predomina o restrito exame da legalidade de despesas e regularidade de contas, para efeito de aplicar sanções (...)" ${ }^{\natural 670}$. A condenação de ordem financeira, portanto, decorrerá mais de ilegalidade do que não alcance de resultados almejados na parceria propriamente dita.

\subsubsection{Inabilitação}

As irregularidades identificadas pelo TCU, quando forem graves as infrações cometidas, poderão implicar na inabilitação do agente público ${ }^{671}$, por um período que variará

\footnotetext{
${ }^{666}$ Márcia Maria Barreto Fernandes Semer. Competências constitucionais do Tribunal de Contas. (cit.), 2000. p. 108.

${ }^{667}$ Francisco Eduardo Carrilho Chaves. Controle externo da gestão pública: a fiscalização pelo legislativo e pelos Tribunais de contas: teoria e jurisprudência. (cit.), 2007. p. 287.

668 “A ausência de comprovação da aplicação dos recursos federais, em decorrência da omissão no dever de prestar contas, importa no julgamento pela irregularidade das contas, na condenação em débito e na aplicação de multa ao responsável”. Cf. Acórdão TCU n. 2843-2009-Segunda Câmara, Ministro André Luís de Carvalho, que versou sobre TCE de valor transferido a ONG para destinação ao Fórum de Ongs Aids do Estado de Goiás. A responsável foi condenada a devolução do valor integral transferido, corrigido, com juros e multa.

${ }^{669}$ Pedro Roberto Decomain. Tribunais de Contas no Brasil. (cit.), 2006. p. 91.

${ }^{670}$ Sebastião Baptista Affonso. Evolução do controle externo. (cit.), jan./mar. 2004. p. 17.

${ }^{671}$ Opina Márcia Pelegrini que "em nenhuma hipótese poderia a Corte de Contas aplicar a pena de inabilitação
} 
de cinco a oito anos, para o exercício de cargo em comissão ou função de confiança no âmbito da Administração Pública (art. 60 da LOTCU do TCU e art. 270 do RITCU). Esta sanção não impede a incidência de outras previstas em lei e de penalidades administrativas.

Sobre a aplicabilidade desta sanção aos dirigentes - e demais funcionários - das ONGs caberia perguntar se a Lei, ao referir-se a agente público, teria feito distinção em relação à expressão responsáveis, que os abrangeria. Ainda, de se questionar se os funcionários públicos cedidos às OSs poderiam ser dela objeto, diferenciando-se dos demais privados atuantes em sua estrutura.

Opinamos no sentido de as irregularidades cometidas em prejuízo ao erário nestas situações terem o condão de fazer incidir sobre seus atores, ainda que não funcionários públicos, todas estas sanções, inclusive para evitar o seu ingresso em cargo em comissão ou função de confiança. Entendemos não haver distinção em ser gestor público ou privado de recursos públicos para fins de configuração de crimes ou irregularidades e consequente sanção de inabilitação, a despeito de sua declaração poder implicar em diferentes consequências em um ou outro caso.

\subsubsection{Inidoneidade}

Outra sanção consiste na declaração, pelo $\mathrm{TCU}^{672}$, de inidoneidade do fraudador de licitação pelo período de até cinco anos, impedindo-o de participar de licitação no âmbito federal (art. 46, LOTCU e 271 do RITCU). Trata-se de sanção destinada a terceiro, não integrante da Administração, que agiu de forma ilícita em certame ${ }^{673}$, podendo ser revista

para ocupantes de cargos estruturantes de qualquer dos Poderes controlados" - o que dirá de entidades do terceiro setor, acrescentamos. Márcia Pelegrini. A Competência Sancionatória do Tribunal de Contas no exercício da função controladora: contornos constitucionais. [cit.], 2008, p. 148.

De acordo com o TCU, em decisão proferida no Acórdão n. 97/2009- Plenário, julgou, em processo de TCE, irregular execução de convênio, condenando agentes públicos e representante de ONG a restituir valores envolvidos e pagar multa pelo dano causado, com base no art. 57 da LOTCU. Aos agentes públicos acresceuse a sanção de inabilitação e possibilidade de desconto dos valores devidos em seus vencimentos. A possibilidade de desconto integral ou parcelado da dívida nos vencimentos, proventos e salários de responsáveis está prevista no art. 28 da LOTCU, e sua aplicabilidade merece previsão em norma específica conforme a esfera federal.

Na esteira de Jorge Ulisses Jacoby Fernandes o TCU somente pode determiná-lo em relação a "responsáveis públicos", sem necessidade de sua anuência. Tomada de Contas Especial: processo e procedimento nos Tribunais de Contas e na Administração Pública. (cit.), 2005a. p. 561-565.

${ }^{672}$ Para Benjamin Zymler, a medida não se confunde com a declaração de inidoneidade prevista no art. 87, inciso IV da Lei Federal n. 8.666/93, aplicada pela própria Administração, que pode ser objeto de reabilitação quando do ressarcimento à Administração dos prejuízos resultantes e após transcurso de dois anos. Benjamin Zymler. Direito Administrativo e Controle. (cit.), 2005. p. 470.

${ }^{673}$ Márcia Maria Barreto Fernandes Semer. Competências constitucionais do Tribunal de Contas. (cit.), 2000. p. 111. 
mediante instrumentos recursais disponíveis no $\mathrm{TCU}^{674}$ ou no Poder Judiciário.

A despeito de a Lei mencionar licitação, fraudes poderão ocorrer em seleção de projetos e celebração de parcerias com entidades do terceiro setor, a justificar reconsideração do preceito legal para envolvê-las.

No Acórdão n. 862/2009-Plenário, o TCU não declarou dada Cooperativa inidônea por entender não ter sido demonstrada a fraude em contratação emergencial realizada. Entretanto, decidiu pela inidoneidade do terceiro pretendente de contratação fraudulenta com a $\mathrm{ONG}^{675}$.

Quanto à possibilidade de aplicação da sanção em comento pelas entidades do terceiro setor sobre suas contratadas, o TCU já se pronunciou pela negativa, por defender a incidência da Lei Federal n. 8.666/93 em partes, sobre e pelas entidades do terceiro setor gestoras de recursos públicos, sobretudo quando envolver poderes intrínsecos à Administração Pública ${ }^{676}$. Esta prerrogativa, portanto, permaneceria com o Poder Público e o TCU.

\subsubsection{Procedimento de aplicação de sanção decorrente de julgamento pela} irregularidade de contas

Uma vez verificada a irregularidade nas contas, o relator ou o Tribunal (art. 202, RITCU) definirá a responsabilidade individual ou solidária pelo ato de gestão inquinado (art. 12 da LOTCU) e, em havendo débito, ordenará a citação do responsável para apresentar alegações de defesa ou recolher a quantia devida.

Em atenção ao art. 16 da Lei Orgânica, o Tribunal, ao julgar irregulares as contas em razão de (i) dano ao erário decorrente de ato de gestão ilegítimo ou antieconômico ou (ii) desfalque ou desvio de dinheiros, bens ou valores públicos, fixará a responsabilidade solidária do agente público pelo ato irregular e do terceiro que, como contratante ou parte interessada na prática do mesmo ato, haja concorrido para o dano apurado ${ }^{677}$. Neste caso, providenciará a

\footnotetext{
${ }^{674}$ Benjamin Zymler. Direito Administrativo e Controle. (cit.), 2005. p. 471.

${ }^{675}$ A título de exemplo, o Acórdão n. 877/2007-Plenário. BRASIL. TCU. Acórdão n. 877/2007 - Plenário. Disponível em: <http//:www.tcu.gov.br>. Acesso em: 28 set. 2009.

${ }^{676}$ BRASIL. TCU. Acórdão n. 1777/2005 - Plenário. Disponível em: <http//:www.tcu.gov.br>. Acesso em: 28 set. 2009. BRASIL. TCU. Acórdão n. 1331/2008 - Plenário. Disponível em: <http//:www.tcu.gov.br >. Acesso em: 28 set. 2009.

${ }^{677}$ SÚMULA TCU n. 133: "Não só os dirigentes de órgãos da Administração Direta e das autarquias, mas também os Administradores das empresas públicas, sociedades de economia mista e Fundações, ou das demais entidades previstas na Lei ${ }^{0}$ 6.223, de 14/07/75 (Lei $n^{\circ} 6.525$, de 11/04/78), estão sujeitos, a juízo do Tribunal de Contas da União, à cominação de multa, por infringência de disposição legal ou regulamentar que lhes seja
} 
imediata e obrigatória remessa de cópia da documentação pertinente ao Ministério Público da União, para ajuizamento das ações civis e penais cabíveis ${ }^{678}$, a ser objeto de tópico específico.

Ademais, o RITCU “deixou expressa a possibilidade de envio de documentação ao MPU nas hipóteses em que houver julgamento das contas irregulares por omissão no dever de prestar contas ou por prática de ato de gestão ilegal, ilegítimo, antieconômico, ou infração a norma legal ou regulamentar de natureza contábil, financeira, orçamentária, operacional ou patrimonial" $" 679$.

Recolhido o valor devido, se não houver outra irregularidade, o TCU poderá sanar o processo, julgando as contas regulares ou regulares com ressalva. Como regra geral, no entanto, o pagamento integral dos valores exigidos não importará em modificação do julgamento pela irregularidade das contas (art. 218, RITCU).

Para Márcia Semer, não caberia ao TCU responsabilizar o beneficiário faltoso pela má utilização do recurso federal, tarefa esta, segundo a autora, de atribuição do Tribunal de Contas da esfera da entidade ou órgão destinatário dos recursos repassados, pois o primeiro “apenas fiscaliza e constata o destino dado ao recurso transferido pela União, concluindo quanto à correção da utilização desse recurso" sob o aspecto legal ou atingimento dos objetivos acordados $^{680}$.

Não nos parece apropriada esta interpretação, pois, na mesma esteira da competência para julgamento da prestação de contas e suas consequências, caberá ao Tribunal de Contas da esfera repassadora de recursos examinar a aplicação deste e responsabilizar o agente faltoso.

aplicável, apurada tanto na fase do controle interno como do externo Enunciados 10, 11, 51 e 91 da Súmula da Jurisprudência do TCU)." SÚMULA TCU n. 186: "Consideram-se sob a jurisdição do Tribunal de Contas da União os co-autores, embora sem vínculo com o serviço público, de peculato praticado por servidores - quer sejam ou não Ordenadores de Despesas ou dirigentes de órgãos - da Administração Direta ou Indireta da União e Fundação instituída ou mantida pelo Poder Público, e, ainda, pertencentes a qualquer outra entidade, que gerencie recursos públicos, independentemente da sua natureza jurídica e do nível quantitativo da sua participação no capital social. A juízo do Tribunal, atentas as circunstâncias ou peculiaridades de cada caso, os aludidos co-autores estão sujeitos à tomada de contas especial, em que se quantifiquem os débitos e se individualizem as responsabilidades ou se defina a solidariedade, sem prejuízo da adoção, pelas autoridades ou pelos órgãos competentes, das medidas administrativas, civis e penais cabíveis, nas instâncias próprias e distintas."

678 “O legitimado ativo para pleitear a execução é, portanto, o patrimônio lesado”. Cf. Jorge Ulisses Jacoby Fernandes. Tomada de Contas Especial: processo e procedimento nos Tribunais de Contas e na Administração Pública. (cit.), 2005a. p. 573.

${ }^{679}$ Francisco Eduardo Carrilho Chaves. Controle externo da gestão pública: a fiscalização pelo legislativo e pelos Tribunais de contas: teoria e jurisprudência. (cit.), 2007. p. 243.

${ }^{680}$ Márcia Maria Barreto Fernandes Semer. Competências constitucionais do Tribunal de Contas. (cit.), 2000. p. 96. 


\subsubsection{Responsabilidade pessoal do agente e/ou da entidade privada}

Vale tecer algumas considerações sobre a responsabilização do agente público ${ }^{681}$, pessoa física representante ou a pessoa jurídica do terceiro setor, parceira do Estado, pelo pagamento de multa combinada ou não com a restituição de valores ao erário.

Ordinariamente, são inscritas como devedoras as pessoas físicas responsáveis pelos danos, independentemente de integrarem a administração pública. Por outro lado, segundo Jorge Ulisses Jacoby Fernandes, não se admite a responsabilização da pessoa jurídica receptora dos recursos "pela recomposição por dano praticado ou pela aplicação de multa",682. A questão, todavia, não é cediça.

Não restam dúvidas acerca da possibilidade de responsabilização pelo TCU do agente público cuja atuação na gestão ou fiscalização de instrumentos de parceria, em todas as suas etapas $^{683}$, foi irregular, seja para arcar individual ou solidariamente com os danos causados ao erário, por recursos desviados e/ou por multa pertinente a cada caso.

Já a responsabilidade das ONGs e seus representantes é controversa e foi abordada no Acórdão TCU n. 709/2008, dele extraindo-se: (i) os seus dirigentes respondem pessoalmente, em regra, por irregularidades ocorridas na gestão de recursos de convênio; (ii) a responsabilização de ONGs, solidariamente com seus dirigentes deve ocorrer apenas nos casos de comprovado desvio de finalidade da aplicação dos recursos do convênio, e somente se revertidos em benefício da entidade; e (iii) a impossibilidade de prejudicar a pessoa jurídica

${ }^{681}$ Consta da Lei das OSs, com redação idêntica na Lei das OSCIPs (art. 12), que os responsáveis pela fiscalização da execução do contrato de gestão, ao tomarem conhecimento de qualquer irregularidade ou ilegalidade na utilização de recursos ou bens de origem pública por organização, dela darão ciência ao Tribunal de Contas da União, sob pena de responsabilidade solidária (art. 9). Muitas vezes, conforme constatado pelo TCU, as irregularidades decorrem da ação ou própria omissão daqueles órgãos públicos que deveriam fiscalizar as entidades privadas parceiras, motivo pelo qual seus representantes têm sido condenados.

${ }^{62}$ Jorge Ulisses Jacoby Fernandes. Tomada de Contas Especial: processos e procedimento nos Tribunais de Contas e na Administração Pública. (cit.), 2005a. p. 549

${ }^{683}$ No Acórdão 2066/2006 - Plenário, o TCU determinou à Secretaria Geral de Controle Externo (Segecex) que orientasse o corpo técnico da Corte no sentido de: "ao realizar auditorias em convênios, termos de parceria, acordos, ajustes e outros instrumentos utilizados para transferir recursos federais a Organizações NãoGovernamentais, concentre esforços na avaliação do controle preventivo que deve ser exercido pelo órgão/entidade concedente, na fase de análise técnica das proposições e celebração dos instrumentos, atentando quanto a eventuais desvios de conduta e/ou negligência funcional de agentes e gestores públicos, caracterizados pela falta ou insuficiência de análises técnicas, especialmente a avaliação da capacidade da entidade convenente para consecução do objeto proposto e para realizar atribuições legalmente exigidas na gestão de recursos públicos e para prestar contas, propondo, entre outras medidas ao seu alcance, a responsabilização pessoal por ato de gestão temerária, instauração de processo disciplinar, inabilitação para o exercício de cargo em comissão ou função de confiança, multas e solidariedade no débito quando a conexão dos fatos assim permitir, especialmente quando não presentes os pressupostos basilares para a celebração: a legitimidade da parceria e a existência de interesse público convergente entre os entes concedentes e convenentes." 
da ONG para o recebimento de recursos federais em futuras oportunidades, se todas as medidas cabíveis forem tomadas contra seus dirigentes faltosos, a fim de obter o ressarcimento ao erário a partir da condenação em débito. Por exemplo, se os dirigentes tomaram providências, após a condenação, para voltar a ser adimplentes com a Administração Pública, ou, caso isso não ocorra, sejam substituídos na gestão da entidade.

Naquela oportunidade, evidenciou-se não serem pacíficos no Tribunal os pressupostos de responsabilização da pessoa jurídica beneficiária de recursos públicos por meio de convênios, na esteira da problemática presente na responsabilização de entes federativos ${ }^{684}$.

Segundo o citado Acórdão, há deliberações do TCU no sentido de:

ser a ONG responsável, juntamente aos seus dirigentes ${ }^{685}$, mesmo não comprovado ter se beneficiado com os recursos desviados de sua finalidade original;

(ii) apenas os dirigentes da ONG devem ser citados para justificar o emprego dos recursos do convênio ${ }^{686}$ e por ele responsabilizarem-se ${ }^{687}$, "sem embargo de surgir a responsabilidade da pessoa jurídica convenente" ${ }^{688}$;

${ }^{684}$ Decisão Normativa TCU n ${ }^{\circ} 57 / 2004$, “Art. $3^{\circ}$. Caso comprovado que o ente federado se beneficiou pela aplicação irregular dos recursos federais transferidos, o Tribunal, ao proferir o julgamento de mérito, condenará diretamente o Estado, o Distrito Federal ou o Município, ou a entidade de sua administração, ao pagamento do débito, podendo, ainda, condenar solidariamente o agente público responsável pela irregularidade e/ou cominar-lhe multa." Disponível em: <http://www.tcu.gov.br>. Acesso em: 06 out. 2009.

${ }^{685}$ BRASIL. TCU. Acórdão TCU no 564/2008 - $1^{\text {a }}$ Câmara. Disponível em: http://www.tcu.gov.br. Acesso em: 29 set. 09. Destaca-se que neste acórdão foi verificada a irregularidade de contas de sindicato que celebrou convênio com o Ministério da Agricultura, Pecuária e Abastecimento, ao que parece considerada entidade do terceiro setor pelo TCU. BRASIL, TCU, Acórdão TCU $n^{\circ}$ 2.080/2005 - $2^{\text {a }}$ Câmara. Disponível em: http://www.tcu.gov.br. Acesso em: 29 set. 09. Neste caso, o TCU concluiu pela responsabilidade solidária da Sociedade Educacional Santa Rita por irregularidade nas contas prestadas, e também pela imputação de débito em razão da ausência de comprovação de alcance dos objetivos previstos em convênio.

${ }^{686}$ BRASIL. TCU. Acórdão TCU no 1.666/2006 - $1^{\text {a }}$ Câmara. Disponível em: http://www.tcu.gov.br. Acesso em: 29 set. 09. Neste Acórdão, foram verificadas as contas prestadas por entidade (por vezes denominada empresa), julgadas regulares Secretaria de Políticas para o Desenvolvimento Sustentável. Contudo, realizada auditoria pelo TCU, constatou-se que aquela havia contratado empresas de mesmo sócio presidente da convenente para fins de realização de convênio. A condenação dirigiu-se exclusivamente aos responsáveis, não à entidade.

BRASIL. TCU. Acórdão TCU no 2.643/2007 - 1ª Câmara. Disponível em: http://www.tcu.gov.br. Acesso em: 29 set. 09. Extraem-se deste Acórdão as relevantes considerações a seguir, acerca do tema ora em exame:

“6. Análise - A jurisprudência deste Tribunal é no sentido de atribuir responsabilidade pessoal do gestor pela comprovação da boa e regular aplicação dos recursos federais recebidos mediante convênio (Acórdãos $\mathrm{n}^{\circ} \mathrm{s}$ 371/99-2 ${ }^{a}$ Câmara; 384/98-2 ${ }^{a}$ Câmara; 92/99-1ª Câmara; e Decisão nº 667/95-Plenário).

6.1. O Tribunal de Contas da União, no exercício de sua competência, não julga as contas de uma entidade ou órgão, e sim dos administradores e demais responsáveis por dinheiros, bens e valores públicos, conforme o art. 71, inciso II, da $\mathrm{CF} / 88$. Há que se considerar que a Administração Pública de per si ou as instituições privadas que atuam em colaboração com o Estado não praticam ato algum, senão por meio de seus representantes legalmente designados, os quais respondem pessoalmente por omissões ou irregularidades decorrentes de atos praticados.

Com relação ao assunto, é oportuno reproduzir excerto da ementa do julgamento proferido pelo Supremo Tribunal Federal, nos autos do MS n 21.644-DF (Rel. Min. Néri da Silveira, Julgamento: 4/11/1993, Tribunal Pleno, D.J. de 8/11/1993, pág. 43.204): 'Mandado de Segurança. Tribunal de Contas da União. 
ocorrer nos casos de direto e comprovado benefício à entidade dos recursos aplicados com desvio de finalidade.

Para fins de condenação, o TCU considera a boa fé e o período entre a ocorrência dos fatos irregulares, o seu processamento e a possibilidade de saneamento. Neste sentido, esposou entendimento pela não condenação ou emissão de juízo de valor sobre as contas de responsável convenente, em nome da segurança jurídica e da razoabilidade. Para tanto, fundamentou-se no lapso temporal de quase duas décadas após o período dos fatos, porque então impossível promover o saneamento das irregularidades evidenciadas após a juntada de documentos pelo responsável ${ }^{689}$.

Alguns efeitos diretos da atuação do TCU, como a condenação por débito decorrente de dano, poderão atingir o patrimônio dos herdeiros dos representantes das ONGs até o limite

2. Prestação de contas referente à aplicação de valores recebidos de entidades da administração indireta, destinados a Programa Assistencial de Servidores de Ministério, em período em que o impetrante era Presidente da Associação dos Servidores do Ministério.

3. O dever de prestar contas, no caso, não é da entidade, mas da pessoa física responsável por bens e valores públicos, seja ele agente público ou não.'

6.2. No mesmo sentido, destaco trecho do voto do Exmo. Sr. Ministro Ubiratan Aguiar, Acórdão n ${ }^{\mathrm{o}} 27 / 2004-2^{\mathrm{a}}$ Câmara, Sessão de 22/1/2004, Ata n 1/2004: 'Por fim, saliento, que todo aquele que gere recursos públicos submete-se, por dever constitucional, à obrigação de demonstrar o seu correto emprego, inclusive no que respeita à observância dos princípios que regem a administração pública, definidos no art. 37 da Constituição Federal. A concretização de tal dever se dá mediante a apresentação, no prazo acertado e na forma definida nas normas aplicáveis, de todos comprovantes hábeis a mostrar, de forma transparente, a licitude dos atos praticados e o alcance das metas pactuadas. Assim, nos termos do art. 71, inciso II, da Constituição Federal, este Tribunal mune-se de competência para julgar as contas de todo aquele que gerir bens e valores públicos, a exemplo dos recursos federais descentralizados por meio de convênios ou outros instrumentos congêneres.' (Grifo da Unidade Técnica)

6.3. Vê-se, portanto, que, diferentemente das relações de natureza contratual, nas quais a responsabilidade do contratado, em princípio, restringe-se à pessoa jurídica da entidade privada contratada, no caso de convênio entre a administração e outra entidade pública ou privada, o dirigente da entidade convenente é pessoalmente responsável pela aplicação dos recursos públicos. Tal entendimento arrima-se, entre outros, no art. 145 do Decreto $n^{\circ}$ 93.872/86, in verbis: 'Art. 145 - Quem quer que utilize dinheiros públicos terá de justificar seu bom e regular emprego na conformidade das leis, regulamentos e normas emanadas das autoridades administrativas competentes."

${ }^{687}$ O TCU já julgou irregulares as contas de representantes de OSCIP que celebraram convênio com o Poder Público por ausência de prestação de contas ao órgão público parceiro, bem como prova de alcance dos objetos pretendidos por aquele instrumento de parceria. A TCE foi instaurada em face do Fundo Nacional de Saúde e remetida ao TCU. BRASIL, TCU, Acórdão n.4953/2009 - Segunda Câmara. Disponível em: www.tcu.gov.br. Acesso em: 29 set. 2009

${ }^{688}$ BRASIL. TCU. Acórdão TCU no 1.693/2003 - Plenário. Disponível em: http://www.tcu.gov.br. Acesso em: 29 set. 09.

${ }^{689}$ Conferir o voto proferido em Acórdão 3406/2007 - Segunda Câmara: "Não pode ser ignorada, in casu, a inércia da administração, que contribuiu decisivamente para que fosse ultrapassado o prazo previsto nos normativos citados e por não ter instaurado, no tempo oportuno, a devida tomada de contas especial, ante a omissão do responsável em apresentar a prestação de contas do convênio. Faço lembrar que este Tribunal, em recente deliberação (Acórdão 64/2007-TCU - 2 $2^{\mathrm{a}}$ Câmara), considerou que a inércia é passível de responsabilização daqueles que lhe derem ensejo, nos termos da legislação atual (arts. $1^{\circ}$ e $2^{\circ}$ da IN/TCU 13/96), visto que o ordenador de despesa da unidade concedente tem prazos definidos para se pronunciar sobre a prestação de contas a ele submetida ou instaurar a Tomada de Contas Especial, nos termos dos arts. 31 e 40 da IN STN 1/1997”. 
da herança. No caso de falecimento do responsável por pagamento de multa, estará extinta a possibilidade de cobrança, dado seu caráter personalíssimo ${ }^{690}$.

\subsubsection{Condenação comportamental}

A condenação comportamental integra a definição de efeito direto da atuação do TCU, referindo-se a determinação ou recomendação deste no sentido de consecução ou omissão por entidade do terceiro setor acerca de dado assunto. Pode decorrer de fiscalização, prestação ou tomada de contas e TCE.

Dotada de caráter pedagógico ${ }^{691}$, a condenação comportamental diferencia-se da decisão meramente punitiva. Visa recomendar procedimentos ou omissões no sentido de melhoria da gestão pública e de sua fiscalização, configurando-se papel importante do TCU sob a ótica do controle de resultado, com destaque para os acórdãos relativos a auditorias operacionais.

A condenação comportamental pode integrar decisão no sentido da regularidade das contas, a título orientativo, ou compor condenação a pagamento de débito ou multa em decorrência de irregularidades.

As fiscalizações pelo TCU normalmente são realizadas quando já superadas as fases do controle prévio e concomitante, ensejando a definição de algumas falhas como ‘irregularidades formais', sem responsabilização dos servidores públicos ${ }^{692}$ ou condenação de ordem financeira. Nestes casos, prepondera a condenação comportamental.

\subsubsection{Inscrição no CADIRREG e no CADIN}

Outro efeito direto da atuação do TCU é a inclusão no seu Cadastro de Responsáveis com Contas Julgadas Irregulares - CADIRREG do nome das pessoas, físicas ou jurídicas, vivas ou falecidas, detentoras ou não de cargo/função pública, cujas contas foram julgadas irregulares.

\footnotetext{
${ }^{690}$ Jorge Ulisses Jacoby Fernandes. Tomada de Contas Especial: processos e procedimento nos Tribunais de Contas e na Administração Pública. (cit.), 2005a. p. 556.

${ }^{691}$ Evandro Martins Guerra. Os controles externo e interno da Administração pública. (cit.), 2005. p. 242.

${ }^{692}$ Neste sentido, conferir Natasha Caccia Salinas. Avaliação Legislativa no Brasil: um estudo de caso sobre as normas de controle das transferências voluntárias de recursos públicos para entidades do terceiro setor. (cit.) 2008. p. 191.
} 
Ainda, se não quitado o valor ao qual o responsável foi condenado a pagar ou a devolver, o TCU adotará providências para inclusão do seu nome, por intermédio do órgão público parceiro ou outro competente, no cadastro informativo de créditos não quitados do setor público federal - CADIN, na forma estabelecida em ato normativo (art. 219, RITCU c/c IN N. 41/02 e DN 45/02) ${ }^{693}$.

O nome do responsável poderá ser excluído do CADIN se (i) ele recolher o débito; (ii) o TCU, a despeito de julgar irregulares as contas, afastar o débito do responsável; (iii) ao julgar as contas regulares ou irregulares com ressalva, o TCU entendê-las como iliquidáveis; (iv) excluir a responsabilidade do agente; (v) parcelar o débito e ficar comprovado o pagamento da primeira parcela ${ }^{694}$.

\subsection{Efeitos indiretos}

São denominados efeitos indiretos das atribuições do TCU os que dependam da decisão e da atuação de terceiros para sua consecução, como "externalidades" das decisões daquele em outras esferas e Poderes.

\subsubsection{Inelegibilidade}

Os responsáveis por irregularidades insanáveis em decisão irrecorrível do órgão competente serão inelegíveis para quaisquer ${ }^{695}$ cargos, nas eleições realizadas nos cinco anos seguintes da data da decisão que rejeitar as suas contas, salvo se objeto de apreciação pelo Poder Judiciário (art. 1º, inciso I, alínea g, da Lei Complementar $n^{\circ}$ 64/1990).

\footnotetext{
${ }^{693}$ Segundo a Decisão Normativa n. 45/02:

"Art. $2^{\circ}$ Quando houver aplicação de multa pelo Tribunal, a Secex competente comunicará à Secretaria do Tesouro Nacional para que inclua o nome do responsável no CADIN, observada a legislação vigente. (NR) (Decisão Normativa 52, de 3.12.2003).

Art. $3^{\circ}$ Quando houver condenação ao pagamento de débito por contas julgadas irregulares, a SECEX competente comunicará ao órgão ou entidade a que se vincula originariamente o crédito, ou seu sucessor, para que inclua o nome do responsável no CADIN, observada a legislação vigente.

Art. $4^{\circ}$ As providências para inclusão no CADIN apenas serão tomadas após transitado em julgado o acórdão condenatório e caso não comprovado, no prazo estabelecido, o recolhimento da dívida.

Parágrafo único. Para os fins desta decisão normativa, considera-se transitado em julgado o acórdão que não mais se sujeita aos recursos previstos nos arts. 32, incisos I e II, e 48 da Lei $n^{\circ} 8.443 / 92$, nos seus prazos normais de interposição."

Disponível em: www.tcu.gov.br. Acesso em: http://www.tcu.gov.br.

${ }^{694}$ Guilherme Henrique de la Rocque Almeida. Controle das transferências financeiras da União. (cit.), 2008a. p. 259.

${ }^{695}$ A gravidade da sanção resta evidente quando se verifica nos demais incisos que a inelegibilidade poderia se restringir a apenas alguns cargos.
} 
Para tanto, o TCU enviará ao Ministério Público Eleitoral o nome dos responsáveis por contas julgadas irregulares nos cinco anos imediatamente anteriores à época da realização das eleições no âmbito da União, dos Estados, do Distrito Federal e dos Municípios (art. 220 do RITCU e IN TCU 56/2007).

Trata-se de comunicação de natureza declaratória, devendo a Justiça Eleitoral decidir a respeito da inelegibilidade ${ }^{696}$ se extrair do acórdão do TCU serem insanáveis as irregularidades ${ }^{697}$.

A natureza sancionatória da inclusão do nome do responsável em lista de inelegíveis para envio à Justiça Eleitoral ${ }^{698}$ pelo TCU foi objeto de questionamento e análise pelo Supremo Tribunal Federal, concluindo pela natureza meramente procedimental do ato.

Verifica-se a importância dada à rejeição das contas de responsável por irregularidades, podendo ser amenizada mediante questionamento acerca da improbidade de seus atos ${ }^{699}$ junto ao Poder Judiciário ${ }^{700}$, quando, por expressa previsão legal, será elegível.

O RITCU (art. 220, § $2^{\circ}$ ) acrescentou à citada exceção a inaplicabilidade do disposto no art. 220 do RITCU aos processos pendentes de recurso com efeito suspensivo cuja admissibilidade tenha sido reconhecida pelo relator.

Há controvérsia sobre a inclusão dos gestores privados de recursos públicos no rol dos inelegíveis, se julgadas suas contas irregulares pelo TCU.

Para Jorge Ulisses Jacoby Fernandes a referida inclusão não se faz possível por restringir este efeito aos ocupantes de função pública. Em sua opinião, se houver indícios de

\footnotetext{
${ }^{696}$ Jorge Ulisses Jacoby Fernandes. Tomada de Contas Especial: processo e procedimento nos Tribunais de Contas e na Administração Pública. (cit.), 2005a. p. 547.

${ }^{697}$ Ibid., p. 543.

${ }^{698}$ BRASIL. Supremo Tribunal Federal. Mandado de Segurança n. 22.087-2. Relator: Ministro Carlos Velloso, Brasília, 28 de março de 1993. Diário [da] Justiça, Brasília, DF, 10 de maio 1995. Seção I, p. 15132: “(...)

(i) Inclusão em lista para remessa ao órgão da Justiça Eleitoral do nome do administrador público que teve suas contas rejeitadas pelo TCU, além de lhe ser aplicada pena de multa. Inocorrência de dupla punição, dado que a inclusão do nome do administrador público na lista não configura punição.

(ii) Inelegibilidade não constitui pena. (...)

(iii) À Justiça Eleitoral compete formular juízo de valor a respeito das irregularidades apontadas pelo Tribunal de Contas, vale dizer, se as irregularidades configuram ou não inelegibilidade.”

699 "É imprescindível que a ação judicial ataque todos os fundamentos que embasaram o decreto de rejeição, além do que a medida deve anteceder a ação de impugnação de registro de candidatura". BRASIL. TRIBUNAL SUPERIOR ELEITORAL. Acórdão n. 12.001/RO. Disponível em: http://www.tse.gov.br. Acesso em: 07 set. 2009.

Pondera Jorge Ulisses Jacoby Fernandes que este posicionamento do TSE poderá implicar em exame do mérito das decisões das Cortes de Contas, o que poderá ferir a autonomia de julgamento destas. Tomada de Contas Especial: processo e procedimento nos Tribunais de Contas e na Administração Pública. (cit.), 2005a. p.546.

${ }^{700}$ Pedro Roberto Decomain. Tribunais de Contas no Brasil. (cit.), 2006. p. 216.
} 
locupletamento ou apropriação indébita, a instauração de competente processo criminal será suficiente para, em caso de condenação, afastar o mau gestor privado das urnas ${ }^{701}$.

Em sentido contrário, filiamo-nos a Pedro Roberto Decomain, por entender ser possível incluir os representantes das entidades privadas parceiras no rol dos inelegíveis se julgadas irregulares as suas contas pelo $\mathrm{TCU}^{702}$, face ao conteúdo jurídico da expressão responsáveis.

Neste sentido, o Manual de Convênios e Outros Repasses do TCU exemplificou: se, ao receber os recursos públicos, o gestor privado perceber não ser possível executar o objeto previsto nos termos propostos no instrumento de convênio, não poderá utilizá-los de maneira diferente, sem consultar e obter aval do órgão concedente. Agir em sentido contrário é considerado falha de natureza grave e normalmente conduz ao julgamento pela irregularidade das contas apresentadas e a inclusão do nome do responsável no cadastro de contas irregulares do TCU, para remessa ao Ministério Público Eleitoral ${ }^{703}$.

O Tribunal Superior Eleitoral decidiu, como fundamento à inelegibilidade de dirigente de ONG receptora de recursos públicos, a sua não desincompatibilização para candidatar-se a vereador, por considerar a atuação da entidade como prestadora de serviços a órgão público em razão de convênio, enquadrando-se assim na limitação legal704 (alínea “i”do inciso II do art. $1^{\text {o }}$ da Lei Complementar n. 64/90).

\subsubsection{Impedimento para celebração de parcerias e recebimento de recursos} públicos

Segundo o Manual de Convênios e Outros Repasses do TCU e o art. 63 da PI n. 127/08, a instauração da TCE ensejará a inscrição de inadimplência relativa a instrumento de parceria no SICONV, impedindo novas transferências de recursos financeiros à entidade. Mediante a instauração da TCE, serão, ainda, identificados e registrados os causadores do dano no SIAFI (PI n. 127/08, art. 63) até apresentarem as contas ou recolherem integralmente o débito.

A vedação a transferência pela instauração de TCE demonstra a importância dada à prestação de contas, mas não encontra fundamento legal. Ademais, em caso de equívoco, no

\footnotetext{
701 Jorge Ulisses Jacoby Fernandes. Tomada de Contas Especial: processo e procedimento nos Tribunais de Contas e na Administração Pública. (cit.), 2005a. p.547.

${ }^{702}$ Pedro Roberto Decomain. Tribunais de Contas no Brasil. (cit.), 2006. p. 215.

${ }^{703}$ BRASIL. TCU. Convênios e Outros Repasses. 2008, p. 43.

${ }^{704}$ BRASIL. TRIBUNAL SUPERIOR ELEITORAL. AGRAVO REGIMENTAL EM RECURSO ESPECIAL

ELEITORAL n. 21874-PR. Disponível em: http://www.tse.gov.br. Acesso em: 07 set. 2009.
} 
entanto, poderá ter ensejada a descontinuidade de atuação da $\mathrm{ONG}$, haja vista a dependência de muitas em relação aos recursos públicos.

De toda forma, o preceito não tem sido observado, dentre outros motivos, pela demora do parceiro público no exame das prestações de contas das entidades privadas, fato este reiteradamente destacado pelo TCU, ensejando a celebração de parcerias com ONGs sem comprovação de regular aplicação dos recursos em instrumentos anteriormente firmados ${ }^{705}$.

\subsubsection{Propositura de processo criminal}

Os responsáveis cujas contas forem julgadas irregulares pelo TCU poderão sofrer, além das consequências acima expostas, o envio dos documentos pertinentes ao Ministério Público Federal para fins de instauração de processo penal.

Para Jorge Ulisses Jacoby Fernandes, se o gestor privado de recursos públicos for condenado criminalmente, será caso de inelegibilidade ${ }^{706}$.

\subsubsection{Propositura de ação de cobrança}

O TCU, ao identificar débitos por prejuízos causados ao erário e/ou aplicar multa, consigna nos respectivos acórdãos a autorização para eventual cobrança dos valores após decorridos os prazos para recolhimento pela via administrativa.

Fundamenta-se na atribuição de título executivo concedido a suas decisões, tornando a dívida líquida e certa (art. 73, $\S 3^{\circ}, \mathrm{CF} / 88$, art. 23, inciso III, alínea $b$, LOTCU, art. 585, VIII, do CPC e IN TCU n. 56/2007). Expirado o prazo para recolhimento, serão remetidas, por intermédio do Ministério Público junto ao TCU, as peças essenciais para a propositura de ação competente (ação de cobrança ou processo de execução para entrega de coisa certa ou restituição de bem $^{707}$ ) pela Advocacia Geral da União ou procuradores das entidades da

\footnotetext{
${ }^{705}$ Vale lembrar exemplo já citado de comportamento irregular em conjunto do Estado e da entidade privada, quando o TCU constatou que a FUNASA sobrestava a exigibilidade de prestação de contas parcial de ONG, contrariando o art. 35 da IN/STN n. ${ }^{\circ}$ 01/1997, de modo que esta não configurasse como irregular - autorizando a continuidade de repasse de recursos públicos. Determinou-se, então, que a FUNASA cessasse tal comportamento, fixando prazo para o convenente sanar a irregularidade ou cumprir a obrigação pendente, e, no caso de não-atendimento, adotasse as providências necessárias à instauração de tomada de contas especial e o registro de inadimplência no SIAFI, sob pena de responsabilidade no caso de omissão. Cf. Acórdão $\mathrm{n}^{\circ}$ 668/2008-TCU-Plenário.

706 Jorge Ulisses Jacoby Fernandes. Tomada de Contas Especial: processo e procedimento nos Tribunais de Contas e na Administração Pública. (cit.), 2005a. p. 547.

${ }^{707}$ Pedro Roberto Decomain. Tribunais de Contas no Brasil. (cit.), 2006. p. 221.
} 
administração indireta ${ }^{708}$.

São legitimados para a promoção de ação de execução em razão de danos causados, segundo Pedro Roberto Decomain, o Ministério Público (não atuante junto ao TCU) ou a pessoa jurídica prejudicada (União, Estado, Distrito Federal, Município, autarquia, empresa pública, sociedade de economia mista ou fundação). O Ministério Público não poderá propor ação de cobrança de pagamento de multa, por força do art. 129, III e IX da CF/88 ${ }^{709}$.

Relata Jorge Ulisses Jacoby Fernandes a preferência de alguns Tribunais em inscrever o acórdão condenatório de ordem financeira em dívida ativa, promovendo a Procuradoria da Fazenda Nacional, na esfera federal, o processo de execução ${ }^{710}$.

\subsubsection{Declaração de Improbidade Administrativa}

A omissão de prestação de contas pela entidade do terceiro setor verificada pelo TCU poderá ter como efeito indireto a declaração de improbidade administrativa (Lei n. 8.249/92, art.11, VI) ${ }^{711}$. Ocorrendo a omissão na prestação de contas, será caso de atuação contrária aos princípios da administração pública ${ }^{712}$, cujas consequências são compostas por (i) ressarcimento integral do dano, se houver; (ii) perda da função pública; (iii) suspensão dos direitos políticos de três a cinco anos; (iv) pagamento de multa civil de até cem vezes o valor da remuneração percebida pelo agente e (v) proibição de contratar com o Poder Público ou receber benefícios ou incentivos fiscais ou creditícios, direta ou indiretamente, ainda que por intermédio de pessoa jurídica da qual seja sócio majoritário, pelo prazo de três anos (art. 11 e 12, III, da Lei de Improbidade Administrativa) ${ }^{713}$.

\footnotetext{
${ }^{708}$ Lei Orgânica da Advocacia Geral da União (Lei n. 6.822/80) e LOTCU, art. 81, inciso III.

${ }^{709}$ Pedro Roberto Decomain. Tribunais de Contas no Brasil. (cit.), 2006. p. 222.

${ }^{710}$ Jorge Ulisses Jacoby Fernandes. Tomada de Contas Especial: processo e procedimento nos Tribunais de Contas e na Administração Pública. (cit.), 2005a. p. 539.

711 O Anteprojeto de Lei do Estatuto de terceiro setor é explícito no sentido de que "às entidades do Terceiro Setor parceiras do Estado aplicam-se as disposições da Lei de Improbidade Administrativa" (art. 35). Verificase que restringiu a incidência da Lei de Improbidade aos casos de relação de parceira da entidade com o Estado, sem indicar explicitamente a gestão de recursos públicos.

${ }^{712}$ Márcia Maria Barreto Fernandes Semer. Competências constitucionais do Tribunal de Contas. (cit.), 2000. p. 113.

${ }^{713}$ Além daquela conduta omissiva, a Lei de Improbidade em comento prevê condutas lesivas ao erário, que também ensejam a sua incidência e que implicam, com a procedência da ação, no dever de (i)

(i) ressarcimento integral do dano; (ii)

(ii) perda dos bens e valores acrescidos ilicitamente ao patrimônio; (iii)

(iii) perda da função pública; (iv)

(iv) suspensão de direitos políticos de cinco a oito anos; (v)

(v) pagamento de multa civil de até duas vezes o valor do dano e (vi)
} 
Ainda, "a apuração de irregularidade ou ilegalidade nas contas examinadas pelo Tribunal de Contas no curso de sua atividade fiscalizatória gera na Administração e no Ministério Público o dever de analisar o cabimento de ação de improbidade"714.

Há outros critérios para a incidência da referida Lei. Para alguns autores, visando salvaguardar os fins públicos norteadores dos atos de subvenção, "a entidade beneficiária e seus agentes passam a ter de cumprir o dever de probidade administrativa, conferindo-lhe a Lei a tutela respectiva contra a atuação dos seus agentes tipificada à luz dos artigos 9, 10 e 11 da Lei n. 8.429/92." ${ }^{715}$ Outros, restringem sua aplicação aos atos relativos ao manejo de recursos públicos.

Ademais, a Lei Federal n. 8.429/92 incide sobre a entidade privada para cuja criação ou custeio recebeu recursos públicos em mais de $50 \%$ do seu patrimônio ou receita $\left(\operatorname{art.~} 1^{\circ}\right.$ ).

Ao analisar a questão se somente cometeriam atos de improbidade administrativa os representantes de ONGs detentoras de mais de $50 \%$ de seu patrimônio ou receita públicos, José Roberto Pimenta Oliveira posicionou-se negativamente. À luz do art. 37 da CF/88, afirmou, pouco importa o percentual de participação dos valores repassados para a criação ou custeio da entidade, pois o que se a plena consecução das finalidades das relações jurídicoadministrativas legitimadoras da gestão de recursos públicos. Ainda, a "Lei de Improbidade Administrativa somente será aplicada quando houver enriquecimento ilícito, dano e atentado grave ao regime jurídico-administrativo, atrelado ao descumprimento do dever de probidade administrativa, reconduzível obrigatoriamente a determinada relação publicista de que participa a entidade."716.

O autor é categórico:

[...] na delimitação subjetiva do dever de probidade administrativa, em regulamentação ao artigo $37-\S 4^{\circ}$ da CF/88, a Lei n. 8.429/92 merece interpretação conforme a Constituição, no sentido de tornar plenamente compatível o âmbito de abrangência pessoal da tutela legal da probidade a toda e qualquer pessoa privada que mantenha relação com o Estado (ou quem faça as suas vezes), integrada ao exercício da função administrativa. [...] mesmo não recebendo qualquer valor patrimonial derivado dos cofres públicos em razão daquela relação ( $v \cdot g$. convênio sem repasse de bens e valores), a entidade particular será tutelada pela Lei de Improbidade [...]. Basta verificar a existência de relação jurídico-administrativa

(vi) proibição de contratar com o Poder Público ou receber benefícios ou incentivos fiscais ou creditícios, direta ou indiretamente, ainda que por intermédio de pessoa jurídica da qual seja sócio majoritário, pelo prazo de cinco anos (arts. 10 e 12, II).

\footnotetext{
${ }^{714}$ Márcia Maria Barreto Fernandes Semer. Competências constitucionais do Tribunal de Contas. (cit.), 2000. p. 114.

${ }^{715}$ José Roberto Pimenta Oliveira. Improbidade administrativa e Terceiro setor. (cit.), 2008, p.173.

${ }^{716}$ Ibid., p. 175.
} 
travada por determinada entidade para sobre ela incidir o regime sancionatório constitucional e legal na conduta de seus agentes.. ${ }^{717}$

Para Pedro Roberto Decomain, no entanto, os atos de improbidade administrativa da entidade deverão estar relacionados aos recursos públicos por ela recebidos, a despeito de não importarem em desvio, perda, malbaratamento ou dilapidação de tais $\operatorname{recursos}^{718}$, não bastando o mero vínculo formal de parceria.

Pelo exposto, a depender da interpretação dos critérios de aplicabilidade da Lei de Improbidade, haverá reflexos no controle exercido sobre o terceiro setor acerca dos atos de gestão de recursos públicos.

Acerca da responsabilidade da entidade ou de seu dirigente por ato de improbidade, poderá ocorrer:

(i) a pessoa jurídica, por verificação da conduta de seus representantes legais, é vítima de ato de improbidade praticado por seus agentes. Neste caso, a responsabilidade pelo ato de improbidade administrativa está restrita aos agentes que praticaram, induziram ou concorreram para a prática do ato ímprobo (art. 2 e 3 da Lei 8.429/92), não devendo por conseguinte a pessoa jurídica ocupar o pólo passivo da ação. [...]. (ii) Os representantes legais e agentes da entidade praticaram o ato ímprobo. Nesta hipótese, deverão todos ocupar o pólo passivo da ação, os agentes na condição respectiva de autor, indutor ou co-autor do ato ímprobo; a entidade, na mesma condição de beneficiária direta ou indireta ${ }^{719}$

A imputação da responsabilidade pela improbidade deve ser idêntica para o administrador público encarregado do repasse e do controle, acompanhamento e avaliação dos recursos destinados às organizações não-governamentais.

\subsubsection{Efeitos indiretos diversos}

Há outros efeitos indiretos decorrentes da atuação do TCU.

Na Lei 8.112/90 (art. 132, I, IV, VII, X e XI c/c art. 137, parágrafo único) previu-se a vedação ao reingresso de servidor demitido ou destituído de cargo em comissão, em razão da prática de crime contra a Administração Pública. A prática de ato de improbidade na aplicação irregular de recursos públicos, lesão aos cofres públicos, dilapidação do patrimônio público e corrupção também se configura fator impeditivo. Não se estendeu aos dirigentes das

\footnotetext{
${ }^{717}$ Ibid., p. 171.

${ }^{718}$ Pedro Roberto Decomain. Improbidade Administrativa. São Paulo: Dialética, 2007. p. 24.

${ }^{719}$ José Roberto Pimenta Oliveira. Improbidade administrativa e Terceiro setor, (cit.), 2008. p. 176.
} 
entidades do terceiro setor receptoras e gestoras de recursos públicos, no entanto, a possibilidade de incidência deste preceito.

Preocupa-se Andréa Nunes, por este motivo, com a possibilidade de participação em concurso público ou processo seletivo para ingressar no serviço público ${ }^{720}$ de ex-dirigente de ONG na situação indicada.

Em que pese a lei referir-se a servidor, opinamos no sentido da aplicabilidade do preceito aos dirigentes de entidade do terceiro setor, por serem responsáveis pela gestão de recursos públicos em situação em tudo semelhante àqueles.

Outro exemplo de efeito indireto da atuação do TCU passível de ocorrer em face de irregularidade e malversação de recursos públicos refere-se a perda da qualificação ou titulação de OS, OSCIP, dentre outras.

Ainda, o TCU, fundamentado na maior parte das vezes no inciso IX do art. 71 da $\mathrm{CF} / 88$, tem determinado providências por parte dos órgãos públicos parceiros em relação a outras entidades públicas e às ONGs, inclusive acerca de seu controle.

A título de exemplo, no Acórdão n. 402/2009, diante de inúmeras irregularidades verificadas no sistema de saúde de indígenas, o TCU determinou (i) ao Ministério da Saúde e ao Ministério do Trabalho e Emprego a fiscalização das relações de trabalho nas ONGs sitas nos Distritos Sanitários Especiais Indígenas; e (ii) ao Ministério Público e Tribunal de Contas do Estado do Mato Grosso a adoção de medidas concernentes à questão entendidas pertinentes $^{721}$.

\footnotetext{
${ }^{720}$ Andréa Nunes. Terceiro setor: Controle e fiscalização. (cit.), 2006. p. 98-99.

${ }^{721}$ BRASIL. TCU. Acórdão n. 402/2009. p. 73. Disponível em: <http://www.tcu.gov.br>. Acesso em: jul. 2009
} 


\section{CONSIDERAÇÕES FINAIS}

No decorrer do presente trabalho, procurou-se demonstrar a importância prática do exercício das atribuições de controle pelos Tribunais de Contas sobre as parcerias celebradas entre o Estado e as entidades do terceiro setor que envolvam a gestão de recursos públicos.

Os referidos Tribunais possuem competência constitucional não só para aferição da observância da legalidade na aplicação dos recursos públicos recebidos, como também para análise da gestão e do alcance dos resultados almejados com as parcerias.

Sobretudo quando constatados inúmeros casos de malversação de recursos públicos pelas referidas entidades privadas, verificada a fragilidade ou a ausência de controle pelos órgãos públicos parceiros e o incipiente controle social, o exercício das competências constitucionais pelos Tribunais de Contas faz-se deveras relevante.

A falsa impressão de que, em o exercendo, implicará em interferência na esfera privada ou ainda, a alegação de que não possuem capacidade operacional para tanto não consistem em argumentos para sua inação ou exercício de competência subsidiária ao controle interno.

Não poderá, todavia, substituir a averiguação da conveniência e oportunidade da Administração e das entidades do terceiro setor. A transição da ênfase no controle de legalidade ao controle de gestão não pode ensejar o seu exame por parte dos Tribunais de Contas, pois se equipara a nefasta situação de ausência de controle à da transferência da atividade administrativa para a instância de controle.

Ademais, há de se ter cautela na sobreposição de controles, fazendo-se de rigor a regulação legislativa do controle social, controle interno, do órgão público parceiro e dos Tribunais de Contas, em suas três esferas, de modo a aprimorar e concretizar a fiscalização que se faz premente.

Por fim, justifica-se o presente trabalho diante da constatação de que a ausência de efetiva físcalização do manejo de recursos públicos enseja, dentre outros, questionamentos acerca dos ideais das parcerias público-privadas com o terceiro setor, podendo colocar em risco valores como a consensualidade e a inclusão dos cidadãos no processo de determinação do interesse público, tão caros à sociedade complexa na qual se inserem. 


\section{REFERÊNCIAS BIBLIOGRÁFICAS}

AFFONSO, Sebastião B. Evolução do controle externo. Revista do Tribunal de Contas da União, Brasília, n. 99, jan./mar. 2004, p. 15-20.

AGUIAR, Afonso G.; AGUIAR, Márcio P. O Tribunal de Contas na ordem constitucional. 2.ed. Belo Horizonte: Fórum, 2008.

AGUIAR, Ubiratan; et al. Convênios e tomadas de contas especial: manual prático. 2.ed. rev. ampl. Belo Horizonte: Fórum, 2007.

ALMEIDA, Fernando D. M. de. Novas Figuras Contratuais no Direito Administrativo. In: Odete Medauar. (Org.). Licitações e Contratos Administrativos. 1 ed. São Paulo: NDJ, 1998, p. 187-207.

ALMEIDA, Guilherme H. L. R. Controle das transferências financeiras da União. Belo Horizonte: Fórum, 2008a.

ALVES, Francisco de Assis. Fundações, organizações sociais, agências executivas, organizações da sociedade de interesse público e outras modalidades de prestação de serviço público. São Paulo: LTr, 2000.

AMARAL FILHO, Marcos Jordao Teixeira do. O ombudsman e o controle da administração. São Paulo: Edusp/Icone, 1993.

AMARAL FILHO, Marcos Jordao Teixeira do. A concessão no contexto da reforma do Estado. In: MEDAUAR, Odete (coord.). Concessão de serviço público. São Paulo: Revista dos Tribunais. 1995.

AMARAL FILHO, Marcos Jordão Teixeira. Privatização no Estado contemporâneo. São Paulo: Ícone, 1996.

ARAGÃO, Alexandre S. Administração pública pluricêntrica. Revista de Direito Administrativo, Rio de Janeiro, n. 227, p. 131-150, jan./mar. 2002.

ARIÑO ORTIZ, Gaspar. Princípios de Derecho público económico: modelos de Estado, gestión pública, regulación económica. Granada: Comares, 1990.

ARIÑO ORTIZ, Gaspar. El retorno a lo privado: ante una nueva encrucijada histórica. In.

(Org). Privatización y liberalización de servicios. Madrid: Universidad Autônoma de Madrid, 1999.

ATALIBA, Geraldo. República e constituição. 2.ed. São Paulo: Malheiros, 2007.

BALEEIRO NETO, Jayme. As organizações sociais e o controle dos Tribunais de Contas. 2002. 118 f. Dissertação (Mestrado em Direito Econômico) - Faculdade de Direito, Universidade Federal da Bahia, $\quad 2002 . \quad$ Salvador, Disponível em: $<$ http://www.tce.ba.gov.br/files/publicacoes/teses_e_dissertacoes/dissertacao_jayme_baleeiro_neto.pdf >. Acesso em: set. 2008.

BARACHO, José A. O. O princípio de subsidiariedade: conceito e evolução. Rio de Janeiro: Forense, 2000.

BARRETO, Pedro H. T. O sistema Tribunais de Contas e instituições equivalentes: um estudo comparativo entre o modelo brasileiro e o da União Europeia. Rio de Janeiro: Renovar, 2004.

BARROSO, Luís R. Tribunal de Contas: algumas competências controvertidas. Rio de Janeiro: Renovar, 2001. (Temas de Direito Constitucional).

BAStOS, Celso R.; TAVARES, André R. As Tendências do Direito Público. São Paulo: Saraiva, 2000.

BASTOS, Celso R; MARTINS, Ives G. Comentários à Constituição do Brasil - promulgada em 5 de outubro de 1998. vol. 4 - tomo III, Art. 70 a 91. 3.ed. atual. São Paulo: Saraiva, 2002.

BINENBOJM, Gustavo. Uma teoria do Direito administrativo: direitos fundamentais, democracia e constitucionalização. 2.ed. São Paulo: Renovar, 2008. 
BITTENCOURT, Fernando Moutinho Ramalho. A conquista do tempo presente: auditoria operacional e legitimidade das instituições de controle. Revista do Tribunal de Contas da União, Brasília, n. 105, jul./set. 2005.

BRAGA, Luziânia C. P. Organizações da sociedade civil de interesse público (OSCIPs): promoção e construção de (novos) direitos e assessoria jurídica de caráter suplementar. Fórum Administrativo Direito Público, Belo Horizonte, ano 5, n. 57, p. 6393-6401, nov. 2005.

BRASIL. Câmara do Município de São Paulo. Lei Orgânica do Município de São Paulo: com suas alterações. São Paulo: CM-SP, 2009. Disponível em: <http://www.camara.sp.gov.br/lom.asp $>$. Acesso em: out. 2009.

BRASIL. Comissão de Juristas. Anteprojeto de Lei Orgânica da Administração Pública Federal e Entes de Colaboração. Brasília-DF, 16 jul. 2009. Disponível em: $<$ http://www.planejamento.gov.br/secretarias/upload/Arquivos/seges/comissao_jur/arquivos/090729_s eges_Arq_leiOrganica.pdf>. Acesso em: set. 2009.

BRASIL. Governo do Estado de São Paulo. Constituição do Estado de São Paulo, de 05 de outubro de 1989. Atualizada em 11 de dezembro de 2009. Disponível em: $<$ http://www.legislacao.sp.gov.br/legislacao/index.htm>. Acesso em: dez. 2009.

BRASIL. Ministério da Fazenda; Ministério do Planejamento e Orçamento. Lei $\mathbf{n}^{\mathbf{0}}$ 9.082, de 25 de julho de 1995. Dispõe sobre as diretrizes para a elaboração da lei orçamentária de 1996 e dá outras providências. Diário Oficial da União, Brasília-DF, 26 jul. 1995. Disponível em: $<$ https://www.planalto.gov.br/ccivil_03/leis/19082.htm>. Acesso em: set. 2008.

BRASIL. Ministério da Justiça. Consulta de Entidades Qualificadas. OSCIPs. Disponível em: $<$ http://www.mj.gov.br/data/Pages/MJ0FA9C8DBITEMIDE0BCB31421184407BADA442DFB11BD DCPTBRIE.htm>. Acesso em: out. 2009.

BRASIL. Ministério da Previdência e Assistência Social. Conselho Nacional de Assistência Social. Resolução $n^{\circ}$ 177, de 10 de agosto de 2000. Diário Oficial da União, Brasília-DF, 24 ago. 2000. Disponível em: <http://www3.dataprev.gov.br/sislex/paginas/72/MPAS-CNAS/2000/177.htm>. Acesso em: out. 2009.

BRASIL. Ministério do Planejamento, Orçamento e Gestão; Ministério da Fazenda; Ministério do Controle e da Transparência. Portaria Interministerial $\mathbf{n}^{\mathbf{0}}$ 127, de 29 de maio de 2008. Estabelece normas para execução do disposto no Decreto $\mathrm{n}^{\circ}$ 6.170, de 25 de julho de 2007, que dispõe sobre as normas relativas às transferências de recursos da União mediante convênios e contratos de repasse, e dá outras providências. Diário Oficial da União, Brasília-DF, 30 mai. 2008. Disponível em: $<$ http://www.cultura.gov.br/site/wp-content/uploads/2008/11/portaria-127-convenios.pdf $>$. Acesso em: set. 2008.

BRASIL. Prefeitura Municipal de Itupeva. Editais. Disponível em: $<$ http://www.itupeva.sp.gov.br $>$. Acesso em: 06 out. 2009.

BRASIL. Presidência da República. Câmara da Reforma do Estado. Plano Diretor da Reforma do Aparelho do Estado. Brasília, DF, nov. 1995. Disponível em: $<$ http://www.planalto.gov.br/publi_04/COLECAO/PLANDI.HTM>. Acesso em: set. 2008.

BRASIL. Presidência da República. Casa Civil. Decreto $n^{\circ}$ 3.504, de 13 de junho de 2000. Altera dispositivos do Decreto n. 2.536, de 6 de abril de 1998, que dispõe sobre a concessão do Certificado de Entidade de Fins Filantrópicos a que se refere o inciso IV do art. 18 da Lei n. 8.742, de 7 de dezembro de 1993. Diário Oficial da União, Brasília-DF, 14 jun. 2000. Disponível em: $<$ http://www.planalto.gov.br/ccivil_03/decreto/D3504.htm>. Acesso em: set. 2008.

BRASIL. Presidência da República. Casa Civil. Decreto $n^{\circ} 4.325$, de 7 de agosto de 2002. Fixa preços mínimos básicos para cafés arábica e robusta, safra 2001/2002, para servirem de base na definição dos respectivos preços de exercício em contratos de opção de venda a serem lançados pelo Governo Federal. Diário Oficial da União, Brasília-DF, 8 ago. 2002. Disponível em: $<$ http://www.planalto.gov.br/ccivil_03/decreto/2002/D4325.htm>. Acesso em: set. 2008. 
BRASIL. Presidência da República. Casa Civil. Decreto n ${ }^{\circ} 4.381$, de 17 de setembro de 2002. Acresce parágrafos ao art. 3. do Decreto n. 2.536, de 6 de abril de 1998, que dispõe sobre a concessão do Certificado de Entidade de Fins Filantrópicos a que se refere o inciso IV do art. 18 da Lei n. 8.742, de 7 de dezembro de 1993. Diário Oficial da União, Brasília-DF, 18 set. 2002. Disponível em: $<$ http://www.planalto.gov.br/ccivil_03/decreto/2002/D4381.htm>. Acesso em: set. 2008.

BRASIL. Presidência da República. Casa Civil. Decreto n ${ }^{\circ} 4.499$, de 4 de dezembro de 2002. Altera o art. 3ํ do Decreto no 2.536, de 6 de abril de 1998. Diário Oficial da União, Brasília-DF, 5 dez. 2002. Disponível em: <http://www.planalto.gov.br/ccivil_03/decreto/2002/D4499.htm>. Acesso em: set. 2008.

BRASIL. Presidência da República. Casa Civil. Decreto $\mathrm{n}^{\circ}$ 5.450, de 31 de maio de 2005. Regulamenta o pregão, na forma eletrônica, para aquisição de bens e serviços comuns, e dá outras providências. Diário Oficial da União, Brasília-DF, 01 jun. 2005. Disponível em: $<$ http://www.planalto.gov.br/ccivil_03/_Ato2004-2006/2005/Decreto/D5450.htm>. Acesso em: set. 2008.

BRASIL. Presidência da República. Casa Civil. Decreto $n^{\circ}$ 5.504, de 5 de agosto de 2005. Estabelece a exigência de utilização do pregão, preferencialmente na forma eletrônica, para entes públicos ou privados, nas contratações de bens e serviços comuns, realizadas em decorrência de transferências voluntárias de recursos públicos da União, decorrentes de convênios ou instrumentos congêneres, ou consórcios públicos. Diário Oficial da União, Brasília-DF, 8 ago. 2005. Disponível em: $<$ http://www.planalto.gov.br/ccivil_03/_Ato2004-2006/2005/Decreto/D5504.HTM>. Acesso em: set. 2008.

BRASIL. Presidência da República. Casa Civil. Decreto ${ }^{0}$ 6.170, de 25 de julho de 2007. Dispõe sobre as normas relativas às transferências de recursos da União mediante convênios e contratos de repasse, e dá outras providências. Diário Oficial da União, Brasília-DF, 14 set. 2007. Disponível em: $<$ http://www.planalto.gov.br/ccivil_03/_Ato2007-2010/2007/Decreto/D6170.htm>. Acesso em: set. 2008 .

BRASIL. Presidência da República. Casa Civil. Decreto $\mathrm{n}^{\circ}$ 6.428, de 14 de abril de 2008. Altera o Decreto n. 6.170, de 25 de julho de 2007, que dispõe sobre as normas relativas às transferências de recursos da União mediante convênios e contratos de repasse. Diário Oficial da União, Brasília-DF, 15 abr. 2008. Disponível em: <http://www.planalto.gov.br/ccivil_03/_ato20072010/2008/decreto/d6428.htm>. Acesso em: set. 2008.

BRASIL. Presidência da República. Casa Civil. Decreto $n^{\circ}$ 6.497, de 30 de junho de 2008. Acresce dispositivos ao Decreto n. 6.170, de 25 de julho de 2007, que dispõe sobre as normas relativas às transferências de recursos da União mediante convênios e contratos de repasse. Diário Oficial da União, Brasília-DF, 1 jul. 2008. Disponível em: <http://www.planalto.gov.br/ccivil_03/_ato20072010/2008/Decreto/D6497.htm>. Acesso em: set. 2008.

BRASIL. Presidência da República. Casa Civil. Decreto $\mathrm{n}^{0}$ 8.666, de 21 de junho de 1993. Regulamenta o art. 37, inciso XXI, da Constituição Federal, institui normas para licitações e contratos da Administração Pública e dá outras providências. Diário Oficial da União, Brasília-DF, 22 jun. 1993. Disponível em: <http://www.planalto.gov.br/ccivil_03/LEIS/L8666cons.htm>. Acesso em: set. 2008.

BRASIL. Presidência da República. Casa Civil. Decreto-Lei no 200, de 25 de fevereiro de 1967. Dispõe sobre a organização da Administração Federal, estabelece diretrizes para a Reforma Administrativa e dá outras providências. Diário Oficial da União, Brasília-DF, 27 fev. 1967. Disponível em: <http://www.planalto.gov.br/ccivil/Decreto-Lei/Del0200.htm>. Acesso em: set. 2008.

BRASIL. Presidência da República. Casa Civil. Emenda Constitucional nº 19, de 04 de junho de 1998. Modifica o regime e dispõe sobre princípios e normas da Administração Pública, servidores e agentes políticos, controle de despesas e finanças públicas e custeio de atividades a cargo do Distrito Federal, e dá outras providências. Diário Oficial da União, Brasília-DF, 05 jun. 1998. Disponível em: $<$ http://www.planalto.gov.br/ccivil_03/constituicao/Emendas/emc/emc19.htm>. Acesso em: set. 2008. 
BRASIL. Presidência da República. Casa Civil. Lei ${ }^{\circ} 10.520$, de 17 de julho de 2002. Institui, no âmbito da União, Estados, Distrito Federal e Municípios, nos termos do art. 37, inciso XXI, da Constituição Federal, modalidade de licitação denominada pregão, para aquisição de bens e serviços comuns, e dá outras providências. Diário Oficial da União, Brasília-DF, 18 jul. 2002. Disponível em: $<$ http://www.planalto.gov.br/ccivil/leis/2002/L10520.htm>. Acesso em: set. 2008.

BRASIL. Presidência da República. Casa Civil. Lei no 9.637, de 15 de maio de 1998. Dispõe sobre a qualificação de entidades como organizações sociais, a criação do Programa Nacional de Publicização, a extinção dos órgãos e entidades que menciona e a absorção de suas atividades por organizações sociais, e dá outras providências. Diário Oficial da União, Brasília-DF, 18 mai. 1998. Disponível em: $<$ http://www.planalto.gov.br/ccivil/LEIS/L9637.htm>. Acesso em: set. 2008.

BRASIL. Presidência da República. Casa Civil. Lei $\mathrm{n}^{\circ}$ 9.648, de 27 de maio de 1998. Altera dispositivos das Leis n. 3.890-A, de 25 de abril de 1961, n. 8.666, de 21 de junho de 1993, n. 8.987, de 13 de fevereiro de 1995, n. 9.074, de 7 de julho de 1995, n. 9.427, de 26 de dezembro de 1996, e autoriza o Poder Executivo a promover a reestruturação da Centrais Elétricas Brasileiras ELETROBRÁS e de suas subsidiárias e dá outras providências. Diário Oficial da União, Brasília-DF, 28 mai. 1998. Disponível em: <http://www.planalto.gov.br/ccivil_03/LEIS/L9648cons.htm>. Acesso em: set. 2008.

BRASIL. Presidência da República. Casa Civil. Lei no 10.266, de 24 de julho de 2001. Dispõe sobre as diretrizes para a elaboração da lei orçamentária de 2002 e dá outras providências. Diário Oficial da União, Brasília-DF, 25 jul. 2001. Disponível em: $<$ http://www.planalto.gov.br/ccivil_03/Leis/LEIS_2001/L10266.htm>. Acesso em: set. 2008.

BRASIL. Presidência da República. Casa Civil. Lei n ${ }^{\circ} 10.522$, de 19 de julho de 2002. Dispõe sobre o Cadastro Informativo dos créditos não quitados de órgãos e entidades federais e dá outras providências. Diário Oficial da União, Brasília-DF, 22 jul. 2002. Disponível em: <http://www.planalto.gov.br/ccivil_03/Leis/2002/L10522.htm>. Acesso em: set. 2008.

BRASIL. Presidência da República. Casa Civil. Lei no 11.096, de 13 de janeiro de 2005. Institui o Programa Universidade para Todos - PROUNI; regula a atuação de entidades beneficentes de assistência social no ensino superior; altera a Lei n. 10.891, de 9 de julho de 2004, e dá outras providências. Diário Oficial da União, Brasília-DF, 14 jan. 2005. Disponível em: $<$ http://www.planalto.gov.br/ccivil_03/_Ato2004-2006/2005/LEI/L11096.htm>. Acesso em: set. 2008.

BRASIL. Presidência da República. Casa Civil. Lei no 11.514, de 13 de agosto de 2007. Dispõe sobre as diretrizes para a elaboração e execução da Lei Orçamentária de 2008 e dá outras providências. Diário Oficial da União, Brasília-DF, 14 ago. 2007. Disponível em: <http://www.planalto.gov.br/ccivil_03/_Ato2007-2010/2007/Lei/L11514.htm>. Acesso em: set. 2008.

BRASIL. Presidência da República. Casa Civil. Lei no 11.768, de 14 de agosto de 2008. Dispõe sobre as diretrizes para a elaboração e execução da Lei Orçamentária de 2009 e dá outras providências. Diário Oficial da União, Brasília-DF, 15 ago. 2008. Disponível em: $<$ http://www.planalto.gov.br/ccivil_03/_ato2007-2010/2008/Lei/L11768.htm>. Acesso em: set. 2008.

BRASIL. Presidência da República. Casa Civil. Lei $n^{\circ}$ 12.101, de 27 de novembro de 2009. Dispõe sobre a certificação das entidades beneficentes de assistência social; regula os procedimentos de isenção de contribuições para a seguridade social; altera a Lei n. 8.742, de 7 de dezembro de 1993; revoga dispositivos das Leis n. 8.212, de 24 de julho de 1991, 9.429, de 26 de dezembro de 1996, 9.732, de 11 de dezembro de 1998, 10.684, de 30 de maio de 2003, e da Medida Provisória n. 2.18713, de 24 de agosto de 2001; e dá outras providências. Diário Oficial da União, Brasília-DF, 30 nov. 2009. Disponível em: <http://www.planalto.gov.br/ccivil_03/_Ato2007-2010/2009/Lei/L12101.htm>. Acesso em: dez. 2009.

BRASIL. Presidência da República. Casa Civil. Lei no 4.320, de 17 de março de 1964. Estatui Normas Gerais de Direito Financeiro para elaboração e controle dos orçamentos e balanços da União, dos Estados, dos Municípios e do Distrito Federal. Diário Oficial da União, Brasília-DF, 23 mar. 1964. Disponível em: <http://www.planalto.gov.br/ccivil_03/LEIS/L4320.htm>. Acesso em: set. 2008. 
BRASIL. Presidência da República. Casa Civil. Lei no 8.212, de 24 de julho de 1991. Dispõe sobre a organização da Seguridade Social, institui Plano de Custeio, e dá outras providências. Diário Oficial da União, Brasília-DF, 25 jul. 1991. Disponível em: $<$ http://www.planalto.gov.br/ccivil_03/LEIS/L8212cons.htm>. Acesso em: set. 2008.

BRASIL. Presidência da República. Casa Civil. Lei no 8.443, de 16 de julho de 1992. Dispõe sobre a Lei Orgânica do Tribunal de Contas da União e dá outras providências. Diário Oficial da União, Brasília-DF, 17 jul. 1992. Disponível em: <http://www.planalto.gov.br/ccivil_03/LEIS/L8443.htm>. Acesso em: set. 2008.

BRASIL. Presidência da República. Casa Civil. Lei no 9.790, de 23 de março de 1999. Dispõe sobre a qualificação de pessoas jurídicas de direito privado, sem fins lucrativos, como Organizações da Sociedade Civil de Interesse Público, institui e disciplina o Termo de Parceria, e dá outras providências. Diário Oficial da União, Brasília-DF, 24 mar. 1999. Disponível em: $<$ http://www.planalto.gov.br/ccivil_03/LEIS/L9790.htm>. Acesso em: set. 2008.

BRASIL. Presidência da República. Lei no 2.536, de 6 de abril de 1998. Dispõe sobre a concessão do Certificado de Entidade de Fins Filantrópicos a que se refere o inciso IV do art. 18 da Lei no 8.742 , de 7 de dezembro de 1993, e dá outras providência. Diário Oficial da União, Brasília-DF, 7 abr. 1998. Disponível em: <http://www.planalto.gov.br/ccivil_03/decreto/d2536.htm>. Acesso em: set. 2008.

BRASIL. Secretaria do Tesouro Nacional. Instrução normativa $n^{\circ}$ 01, de 15 de janeiro de 1997. Disciplina a celebração de convênios de natureza financeira que tenham por objeto a execução de projetos ou realização de eventos e dá outras providências. Diário Oficial da União, Brasília-DF, 31 jan. 1997. Disponível em: $<\mathrm{http} / / /$ www.tesouro.fazenda.gov.br/legislacao/download/contabilidade/IN1_97.pdf $>$. Acesso em: out. 2008.

BRASIL. Supremo Tribunal Federal. Ação Direta de Inconstitucionalidade $n^{\circ} 1934$, de 01 de setembro de 1999. Ação direta de inconstitucionalidade. Impugnação da Lei 9.604, de 5 de fevereiro de 1998. Diário da Justiça do Supremo Tribunal Federal, Brasília-DF, 22 out. 1999. Disponível em: $<$ http://www.stf.jus.br/portal/jurisprudencia/listarJurisprudencia.asp?s1=(ADI\$.SCLA.

1934.NUME.) OU (ADI.ACMS. ADJ2 1934.ACMS.)\&base=baseAcordaos>. Acesso em: out. 2008.

BRASIL. Supremo Tribunal Federal. Mandado de Segurança no 21644/DF. Mandado de segurança. Tribunal de Contas da União. 2. Prestação de contas referente à aplicação de valores recebidos de entidades da administração indireta, destinados a Programa Assistencial de Servidores de Ministério, em período em que o impetrante era Presidente da Associação dos Servidores do Ministério. 3. O dever de prestar contas, no caso, não é da entidade, mas da pessoa física responsável por bens e valores públicos, seja ele agente público ou não. 4. Embora a entidade seja de direito privado, sujeita-se à fiscalização do Estado, pois recebe recursos de origem estatal, e seus dirigentes hão de prestar contas dos valores recebidos; quem gere dinheiro público ou administra bens ou interesses da comunidade deve contas ao órgão competente para a fiscalização. Relator: Néri da Silveira. Diário da Justiça do Supremo Tribunal Federal, n. 218. Brasília, DF, 08 nov. 1996. Disponível em: $<$ http://www.stf.jus.br/portal/diarioJustica/verDiarioProcesso.asp?numDj=218\&dataPublicacaoDj=08/11 /1996\&incidente $=1556243 \&$ codCapitulo $=5 \&$ numMateria $=54 \& \operatorname{codMateria}=2>$. Acesso em: out. 2008 .

BRASIL. Supremo Tribunal Federal. Mandado de Segurança $n^{\circ}$ 22801/DF. Instituições financeiras. Sigilo bancário. Banco Central - Informações ao TCU - Punição - Ilegalidade. Relator: Menezes Direito. LEX do Supremo Tribunal Federal, v. 30, n. 356, 2008, p. 488-517. Brasília, DF, 14 mar. 2008. Disponível

em: $<$ http://www.stf.jus.br/portal/jurisprudencia/listarJurisprudencia.asp?s1=MS.SCLA.+E+22801.NUME.\& base $=$ baseAcordaos $>$. Acesso em: out. 2008.

BRASIL. Supremo Tribunal Federal. Mandado de Segurança no 23627/DF. Direito civil. Empresas. Sociedade. Ingresso e Exclusão dos Sócios na Sociedade. Direito administrativo e outras matérias de Direito público. Atos administrativos. Fiscalização. Relator: Carlos Velloso. Diário da Justiça Eletrônico do Supremo Tribunal Federal, Brasília-DF, 14 jun. 2006. Disponível em: $<$ http://www.stf.jus.br/portal/jurisprudencia/listarJurisprudencia.asp?s1=(MS\$.SCLA. 23627.NUME.) OU (MS.ACMS. ADJ2 23627.ACMS.)\&base=baseAcordaos>. Acesso em: out. 2008. 
BRASIL. Supremo Tribunal Federal. Súmula no 347, de 13 de dezembro de 1963. O Tribunal de Contas, no exercício de suas atribuições, pode apreciar a constitucionalidade das leis e dos atos do poder público. Diário da Justiça Eletrônico do Supremo Tribunal Federal, Brasília-DF, 13 dez. 1963. Disponível em:

$<$ http://www.stf.jus.br/portal/jurisprudencia/listarJurisprudencia.asp?s1=347.NUME.\%20NAO\%20S.FL SV.\&base=baseSumulas $>$. Acesso em: out. 2008.

BRASIL. Tribunal de Contas da União. Acórdão no 1111, 11 de junho de 2008. Plenário. As entidades privadas qualificadas como organizações sociais, quando detentoras de contrato de gestão que as habilitem ao recebimento de recursos públicos provenientes do Orçamento da União, inclusive para pagamento de pessoal, sujeitam-se à observância e aplicação dos princípios que regem a Administração, estatuídos no art. 37, caput, da Constituição Federal de 1988, nos seus processos de seleção e contratação de pessoal, pelo tempo em que vigerem os respectivos contratos de gestão. Relator: Augusto Sherman. Diário Oficial da União, Brasília-DF, 13 jun. 2008. Disponível em: $<$ http://www.tcu.gov.br>. Acesso em: out. 2008.

BRASIL. Tribunal de Contas da União. Acórdão ${ }^{0}$ 1232, de 25 de junho de 2008. Plenário. Representação acerca de irregularidades em contratos de repasse celebrados pelo Ministério do Turismo. Transferência de recursos a entidades privadas para a realização de obras em imóveis de propriedade dessas entidades, contrariando a LDO. Repasses de recursos com objetivos predominantemente privados e sem relação direta com a área de turismo. Transferências de recursos para entidades situadas fora das regiões previstas no programa de regionalização do turismo. Preponderância desses repasses para um único estado. Ausência de pareceres técnicos nos processos de formulação dos contratos de repasse. Audiência dos responsáveis. Determinações. Relator: Ubiratan Aguiar. Diário Oficial da União, Brasília-DF, 30 jun. 2008. Disponível em: <http://www.tcu.gov.br>. Acesso em: jul. 2009.

BRASIL. Tribunal de Contas da União. Acórdão n ${ }^{\circ} 1305,15$ de maio de 2007. Primeira Câmara. Embargos de declaração. Inexistência da omissão alegada. Não-provimento. Relator: Aroldo Cedraz. Diário Oficial da União, Brasília-DF, 18 mai. 2007. Disponível em: <http://www.tcu.gov.br>. Acesso em: out. 2008.

BRASIL. Tribunal de Contas da União. Acórdão n 1331, de 09 de julho de 2008. Plenário. Auditoria em ONGS e OSCIPS, no âmbito de Fiscalização de Orientação Centralizada - FOC. Verificação de irregularidades. Existência de outros processos no âmbito de unidades técnicas nos estados que tratam dessas irregularidades. Recomendações. Arquivamento do feito. Relator: Benjamin Zymler. Diário Oficial da União, Brasília-DF, 11 jul. 2008. Disponível em: <http://www.tcu.gov.br>. Acesso em: out. 2008.

BRASIL. Tribunal de Contas da União. Acórdão no 1372, de 29 de abril de 2008. Primeira Câmara. Prestação de contas. Organização social. Contratação de servidores públicos para prestar serviços de consultoria. Vedação da lei de diretrizes orçamentárias. Determinação. Recurso de reconsideração. Argumentos incapazes de afastar a determinação. Conhecimento. Provimento negado. Relator: Aroldo Cedraz. Diário Oficial da União, Brasília-DF, 05 mai. 2008. Disponível em: $<$ http://www.tcu.gov.br>. Acesso em: out. 2008.

BRASIL. Tribunal de Contas da União. Acórdão $n^{\circ}$ 1386, de 24 de junho de 2009. Plenário. Representação de unidade técnica. Termo de parceria celebrado com organização da sociedade civil de interesse público. Suspensão cautelar da execução do ajuste. Oitivas. Acatamento parcial das justificativas apresentadas. Glosa de despesas. Revogação da medida cautelar. Determinações e recomendações. Monitoramento. Relator: André Luís de Carvalho. Diário Oficial da União, BrasíliaDF, 25 jun. 2009. Disponível em: <http://www.tcu.gov.br>. Acesso em: out. 2009.

BRASIL. Tribunal de Contas da União. Acórdão no 1403, de 23 de julho de 2008. Plenário. Auditoria realizada no Instituto Treinar de Educação e Tecnologia, no âmbito de Fiscalização de orientação Centralizada (FOC - ONGs). Irregularidades. Determinação de instauração de tomadas de contas especiais. Citações. Oitivas de empresas. Audiências. Remessa de documentos a diversas pessoas. Arquivamento do feito. Relator: Benjamin Zymler. Diário Oficial da União, Brasília-DF, 25 jul. 2008. Disponível em: <http://www.tcu.gov.br>. Acesso em: out. 2008. 
BRASIL. Tribunal de Contas da União. Acórdão n ${ }^{\circ}$ 141, de 12 de fevereiro de 2008. Segunda Câmara. Tomada de contas especial. Inexecução parcial do objeto de convênios. Pagamento antecipado pelo valor total das obras. Contas irregulares. Relator: Ubiratan Aguiar. Diário Oficial da União, BrasíliaDF, 15 fev. 2008. Disponível em: <http://www.tcu.gov.br>. Acesso em: out. 2008.

BRASIL. Tribunal de Contas da União. Acórdão no 1562, 15 de julho de 2009. Plenário. Auditoria de conformidade. Verificação da estrutura do órgão e das ações internas voltadas para o controle dos recursos repassados por meio de transferências voluntárias. Constatação da existência de desconformidades. Determinações. Relator: Augusto Sherman Cavalcanti. Diário Oficial da União, Brasília-DF, 17 jul. 2009. Disponível em: <http://www.tcu.gov.br>. Acesso em: out. 2009.

BRASIL. Tribunal de Contas da União. Acórdão $\mathrm{n}^{0}$ 1564, de 15 de julho de 2009. Plenário. Levantamento de auditoria. Fiscobras 2009. Obras de modernização da malha viária do distrito industrial de Manaus. Indícios de irregularidades graves que recomendam a manutenção da paralisação do empreendimento. Determinações. audiências. Oitiva da contratada. Ciência ao Congresso Nacional. Apensamento a outro processo. Relator: André Luís de Carvalho. Diário Oficial da União, BrasíliaDF, 25 jun. 2009. Disponível em: <http://www.tcu.gov.br>. Acesso em: out. 2009.

BRASIL. Tribunal de Contas da União. Acórdão n 1684, de 26 de junho de 2007. Segunda Câmara. Recurso de reconsideração em tomada de contas especial. Conhecimento. Alegações insuficientes para comprovar a regularidade das contas. Negado provimento. Relator: Benjamin Zymler. Diário Oficial da União, Brasília-DF, 28 jun. 2007. Disponível em: <http://www.tcu.gov.br>. Acesso em: out. 2008.

BRASIL. Tribunal de Contas da União. Acórdão no 1752, de 17 de junho de 2008. Segunda Câmara. Representação. Convênio. Fundo Nacional de Saúde. Irregularidades praticadas na contratação de organização social. Audiência. Não-acolhimento das razões de justificativa. Multa. Ciência ao Governo do Estado do Pará e ao Tribunal de Contas do Estado do Pará. Relator: Aroldo Cedraz. Diário Oficial da União, Brasília-DF, 19 jun. 2008. Disponível em: $<$ http://www.tcu.gov.br $>$. Acesso em: out. 2008.

BRASIL. Tribunal de Contas da União. Acórdão $n^{0}$ 1777, de 09 de novembro de 2005 . Plenário. Relatório de Auditoria. Lei n. ${ }^{\circ}$ 9.790/99. Organizações da Sociedade Civil de Interesse Público. Termo de Parceria. Terceiro Setor. Atuação do Tribunal. Limite de remuneração da administração pública. Inaplicabilidade da Lei n..$^{\circ}$ 8.666/93 às OSCIPs. Regularidade previdenciária, fiscal e perante o FGTS. Submissão às vedações estipuladas nas Leis de Diretrizes Orçamentárias. Prévia comprovação de capacidade operacional. Hipóteses de perda de qualificação como OSCIP. Escolha do parceiro privado. Natureza jurídica do Termo de Parceria. Considerações. Melhorias em procedimentos de auditoria. Organizações Não-Governamentais. Parcerias público-privadas. Considerações. Recomendações. Determinação. Envio de cópia do Relatório, Voto e Acórdão ao Ministério do Planejamento, Orçamento e Gestão, ao Ministério da Justiça, à Comissão de Fiscalização e Controle do Senado Federal e à Comissão de Fiscalização Financeira e Controle da Câmara dos Deputados. Arquivamento. Relator: Marcos Vinicios Vilaça. Diário Oficial da União, Brasília-DF, 22 nov. 2005. Disponível em: <http://www.tcu.gov.br>. Acesso em: out. 2008.

BRASIL. Tribunal de Contas da União. Acórdão $n^{\circ} 1836$, de 05 de setembro de 2007. Plenário. Representação. Aceitação das razões de justificativa dos responsáveis pelas falhas na celebração/utilização do contrato de gestão $n^{0}$ 63/99. Exclusão da responsabilidade dos gestores, no caso da ausência do dever de supervisão do contrato de gestão $n^{\circ}$ 63/99. Rejeição das razões de justificativa dos responsáveis pela contratação sem concurso público de pessoal para a execução de programas de saúde sem aplicação de sanção. Para a admissão de Agente Comunitário de Saúde e demais profissionais das Equipes de Saúde da Família, é necessária a realização de processo seletivo público de provas ou provas e títulos, na forma do art. 37, inciso II, da Constituição Federal. Relator: Marcos Vinicios Vilaça. Diário Oficial da União, Brasília-DF, 10 jul. 2007. Disponível em: $<$ http://www.tcu.gov.br>. Acesso em: out. 2008.

BRASIL. Tribunal de Contas da União. Acórdão no 1840, de 16 de agosto de 2005. Primeira Câmara. Representação formulada pelo Juízo da Vara do Trabalho de Ubá - MG. Supostas irregularidades na contratação de profissionais de saúde para atender ao Programa Saúde da Família, no âmbito do Município de Ubá - MG. Comprovação de que a referida contratação encontra respaldo legal, 
porquanto efetuada por intermédio de uma Organização Social da Sociedade Civil de Interesse Público (OSCIP). Conhecimento. Improcedência. Ciência ao Juízo Trabalhista de Ubá-MG. Relator: Guilherme Palmeira. Diário Oficial da União, Brasília-DF, 30 ago. 2005. Disponível em: $<$ http://www.tcu.gov.br>. Acesso em: out. 2008.

BRASIL. Tribunal de Contas da União. Acórdão no 1933, de 19 de setembro de 2007. Plenário. Relatório de Auditoria de conformidade realizada com o objetivo verificar a regularidade dos instrumentos de transferência de recursos. Consolidação dos relatórios referentes ao tema Inclusão Digital. Determinação. Comunicações. Relator: Valmir Campelo. Diário Oficial da União, BrasíliaDF, 21 set. 2007. Disponível em: <http://www.tcu.gov.br>. Acesso em: out. 2008.

BRASIL. Tribunal de Contas da União. Acórdão no 1936, de 10 de dezembro de 2003. Plenário. Representação formulada por unidade técnica do TCU. Possíveis irregularidades praticadas por prefeituras do Estado de Minas Gerais. Execução e prestação de contas de convênios firmados com órgãos da administração pública. Desvio de recursos públicos. Fraude envolvendo prefeito, comissão de licitação, empresas e seus sócios. Existência de débitos de municípios com o FGTS. Plano de trabalho sem projeto adequado. Pagamento indevido. Situação irregular de empresas contratadas, Conhecimento. Procedência. Determinação. Conversão de processos em tomada de contas especial. Recomendação à STN. Remessa de cópia aos órgãos interessados. Arquivamento. Relator: Augusto Sherman Cavalcanti. Diário Oficial da União, Brasília-DF, 23 dez. 2003. Disponível em: $<$ http://www.tcu.gov.br>. Acesso em: out. 2008.

BRASIL. Tribunal de Contas da União. Acórdão n 1952, de 19 de setembro de 2007. Plenário. Projeto de decisão normativa anual que define, para 2008, as unidades jurisdicionadas cujos responsáveis devem apresentar contas ao Tribunal relativas ao exercício de 2007, com a composição das suas peças e forma de organização, consoante dispõe o art. $4^{\circ}$ da IN TCU n ${ }^{\circ} 47 / 2004$. Projeto de instrução normativa para alteração de alguns dispositivos da IN TCU $n^{\circ} 47 / 2004$. Transcurso do prazo fixado pelo plenário sem apresentação de emendas ou sugestões. parecer pela aprovação dos projetos. Relator: Ubiratan Aguiar. Diário Oficial da União, Brasília-DF, 21 set. 2007. Disponível em: $<$ http://www.tcu.gov.br>. Acesso em: out. 2008.

BRASIL. Tribunal de Contas da União. Acórdão no 2044, de 08 de novembro de 2006. Plenário. Tomada de contas especial. Convênio. Omissão no dever de prestar contas. Recurso de revisão. Apresentação e aprovação das contas no órgão repassador. Documento novo. Conhecimento. Inconsistências entre os saques e os pagamentos. Inexistência de menção ao convênio nos comprovantes das despesas. Indícios de fraude. Gastos fora do objeto. Negado provimento. Relator: Marcos Vinicios Vilaça. Diário Oficial da União, Brasília-DF, 13 nov. 2006. Disponível em: < http://www.tcu.gov.br>. Acesso em: out. 2008.

BRASIL. Tribunal de Contas da União. Acórdão no 2066, de 08 de novembro de 2006. Plenário. Relatório Consolidado das Auditorias realizadas com o objetivo de verificar a regularidade da aplicação de recursos federais repassados pela União ou entidades da Administração Indireta a Organizações Não-Governamentais, por meio de convênios, contratos de repasse e instrumentos similares. Determinações. Recomendações. Relator: Marcos Bemquerer Costa. Diário Oficial da União, Brasília-DF, 13 nov. 2006. Disponível em: <http://www.tcu.gov.br>. Acesso em: out. 2008.

BRASIL. Tribunal de Contas da União. Acórdão no 2101, de 18 de outubro de 2005. Segunda Câmara. Tomada de contas especial. Omissão no dever de prestar contas. Contas irregulares. A omissão no dever de prestar contas impõe o julgamento pela irregularidade das contas e a condenação em débito do responsável, com aplicação de multa, não sendo acolhida defesa desacompanhada de elementos comprobatórios. Relator: Lincoln Magalhães da Rocha. Diário Oficial da União, Brasília-DF, 20 out. 2005. Disponível em: <http://www.tcu.gov.br>. Acesso em: out. 2008.

BRASIL. Tribunal de Contas da União. Acórdão $\mathrm{n}^{\circ}$ 2261, 13 de dezembro de 2005. Plenário. Consolidação das auditorias realizadas nos convênios celebrados entre a União e as entidades em epígrafe. Atendimento à Solicitação oriunda do Senado Federal. Situações de desvio dos recursos conveniados. Deficiência nas análises das proposições iniciais, nas prestações de contas e na fiscalização. Fragilidade nos procedimentos de controle. Formação de apartados de tomadas de contas especiais. Conversão de um processo em tomada de contas especial. Determinações. Envio de cópia da 
deliberação às autoridades e órgãos/entidades envolvidos. Relator: Guilherme Palmeira. Diário Oficial da União, Brasília-DF, 03 jan. 2006. Disponível em: <http://www.tcu.gov.br>. Acesso em: out. 2008.

BRASIL. Tribunal de Contas da União. Acórdão n ${ }^{\circ} 2261$, de 13 de dezembro de 2005. Plenário. Consolidação das auditorias realizadas nos convênios celebrados entre a União e as entidades em epígrafe. Atendimento à Solicitação oriunda do Senado Federal. Situações de desvio dos recursos conveniados. Deficiência nas análises das proposições iniciais, nas prestações de contas e na fiscalização. Fragilidade nos procedimentos de controle. Formação de apartados de tomadas de contas especiais. Conversão de um processo em tomada de contas especial. Determinações. Envio de cópia da deliberação às autoridades e órgãos/entidades envolvidos. Relator: Guilherme Palmeira. Diário Oficial da União, Brasília-DF, 03 jan. 2006. Disponível em: <http://www.tcu.gov.br>. Acesso em: out. 2008.

BRASIL. Tribunal de Contas da União. Acórdão n ${ }^{\circ}$ 2578, 05 de outubro de 2004. Primeira Câmara. Representação formulada pelo Tribunal de Contas do Estado do Rio de Janeiro. Supostas irregularidades praticadas pela Prefeitura Municipal de Nilópolis RJ. Programas Saúde da Família e Agentes Comunitários de Saúde. Contratação indireta de pessoal por intermédio de cooperativas. Terceirização de funções típicas da área de saúde. Conhecimento. Procedência. Determinação. Remessa de cópia do Departamento Nacional de Auditoria do SUS do Ministério da Saúde. Relator: Marcos Vinicios Vilaça. Diário Oficial da União, Brasília-DF, 19 out. 2004. Disponível em: $<$ http://www.tcu.gov.br>. Acesso em: out. 2008.

BRASIL. Tribunal de Contas da União. Acórdão no 2619, de 05 de dezembro de 2007. Plenário. Solicitação do Congresso Nacional. CPI das ONGs. Informações sobre transferências de recursos federais a organizações não-governamentais e para Organizações da Sociedade Civil de Interesse Público. Conhecimento. Informação provisória. Relator: Guilherme Palmeira. Diário Oficial da União, Brasília-DF, 11 dez. 2007. Disponível em: <http://www.tcu.gov.br>. Acesso em: out. 2008.

BRASIL. Tribunal de Contas da União. Acórdão n ${ }^{0}$ 2680, de 05 de dezembro de 2007. Plenário. Denúncia. Adoção de medida cautelar em razão de indícios de irregularidades na celebração e execução de convênio celebrado com OSCIP. Oitiva. Acolhimento das justificativas. Revogação da cautelar. Determinações. Relator: Guilherme Palmeira. Diário Oficial da União, Brasília-DF, 11 dez. 2007. Disponível em: <http://www.tcu.gov.br>. Acesso em: out. 2009.

BRASIL. Tribunal de Contas da União. Acórdão no 2697, 26 de novembro de 2008. Plenário. Auditoria de Conformidade. Fiscalização de Orientação Centralizada (FOC). Aplicação de Recursos Federais transferidos mediante convênios. Constatação de irregularidades. Audiência dos responsáveis. Acolhimento das razões de justificativa oferecidas por alguns e acolhimento parcial das alegações trazidas por outros. Recomendações e determinações. Relator: Valmir Campelo. Diário Oficial da União, Brasília-DF, 01 dez. 2008. Disponível em: <http://www.tcu.gov.br>. Acesso em: out. 2008.

BRASIL. Tribunal de Contas da União. Acórdão no 277, 07 de março de 2007. Plenário. Solicitação. CPMI "das ambulâncias". Informações sobre os procedimentos utilizados na fiscalização de convênios. Relator: Marcos Vinicios Vilaça. Diário Oficial da União, Brasília-DF, 09 março. 2007. Disponível em: <http://www.tcu.gov.br>. Acesso em: out. 2008.

BRASIL. Tribunal de Contas da União. Acórdão no 402, de 11 de março de 2009. Plenário. Auditoria Operacional. Funasa. Verificação da efetividade na aplicação de recursos federais em ações assistências e de saúde aos povos indígenas nos Distritos Sanitários Especiais Indígenas. Relator: José Jorge. Diário Oficial da União, Brasília-DF, 13 mar. 2009. Disponível em: <http://www.tcu.gov.br>. Acesso em: jul. 2009.

BRASIL. Tribunal de Contas da União. Acórdão ${ }^{\circ}$ 421, de 14 de abril de 2004. Plenário. Consulta formulada pela Câmara dos Deputados. Contratação, por parte da administração pública direta, de bens ou serviços das entidades dos serviços sociais autônomos com dispensa de licitação. Prerrogativa dada às organizações sociais. Requisitos para contratação com dispensa de licitação. Conhecimento. 
Orientação. Arquivamento. Relator: Augusto Sherman Cavalcanti. Diário Oficial da União, BrasíliaDF, 29 abr. 2004. Disponível em: <http://www.tcu.gov.br>. Acesso em: out. 2008.

BRASIL. Tribunal de Contas da União. Acórdão $\mathrm{n}^{\circ}$ 4522, de 19 de novembro de 2008. Primeira Câmara. Embargos de declaração em sede de recurso de reconsideração. Constatação de obscuridade. Esclarecimentos acerca da fundamentação do voto condutor do acórdão recorrido. Mérito da deliberação não afetado. Relator: Aroldo Cedraz. Diário Oficial da União, Brasília-DF, 21 nov. 2008. Disponível em: <http://www.tcu.gov.br>. Acesso em: out. 2008.

BRASIL. Tribunal de Contas da União. Acórdão n 535, de 02 de abril de 2008. Plenário. Solicitação do Congresso Nacional. CPI das ONGs. Informações complementares sobre transferências de recursos federais a organizações não-governamentais e para organizações da sociedade civil de interesse público. Encaminhamento de cópia do presente acórdão, bem como do relatório e do voto que o fundamentam a referida CPI. Arquivamento. Relator: Guilherme Palmeira. Diário Oficial da União, Brasília-DF, 04 abr. 2008. Disponível em: <http://www.tcu.gov.br>. Acesso em: out. 2008.

BRASIL. Tribunal de Contas da União. Acórdão no 544, de 02 de abril de 2008. Plenário. Relatório de auditoria de natureza operacional. Baixo grau de consistência na elaboração de políticas públicas para o setor de telecomunicações. Ausência de metas para a utilização dos recursos do fundo. Carência de controles de arrecadação. Irregularidades na elaboração e execução de convênios, contratos de repasses e congêneres. Determinações. Envio de cópias. Relator: Raimundo Carreiro. Diário Oficial da União, Brasília-DF, 04 abr. 2008. Disponível em: <http://www.tcu.gov.br>. Acesso em: out. 2008.

BRASIL. Tribunal de Contas da União. Acórdão $n^{\circ}$ 601, de 20 de março de 2007. Primeira Câmara. Recurso de reconsideração. Organização social. Sujeição a normas gerais de licitação e de administração financeira do poder público. Obrigatoriedade de utilização de pregão. Não provimento. Relator: Aroldo Cedraz. Diário Oficial da União, Brasília-DF, 26 mar. 2007. Disponível em: $<$ http://www.tcu.gov.br>. Acesso em: out. 2008.

BRASIL. Tribunal de Contas da União. Acórdão nº 613, de 09 de abril de 2008. Plenário. Solicitação. Prestação de contas anuais pela Associação de Comunicação Educativa Roquete Pinto - ACERP e pela Empresa Brasil de Comunicação - EBC. A ACERP está dispensada de prestar contas anuais ao TCU. Autorização para a EBC prestar contas relativas ao exercício de 2007 juntamente com as contas do exercício de 2008. Relator: Raimundo Carreiro. Diário Oficial da União, Brasília-DF, 14 abr. 2008. Disponível em: <http://www.tcu.gov.br>. Acesso em: out. 2008.

BRASIL. Tribunal de Contas da União. Acórdão no 668, de 16 de abril de 2008. Plenário. Auditoria operacional. Funasa. Avaliação da adequação da estrutura e dos meios da entidade perante seus objetivos institucionais. Ineficácia dos controles internos nas áreas de administração de pessoal e de formalização de convênios. Gastos excessivos na área administrativa em detrimento da atividade-fim. Utilização do instituto denominado sobrestamento quando da não-aprovação das prestações de contas parciais de convênios, visando possibilitar o repasse de recursos. Determinações. Recomendações. Juntada às contas. Relator: Guilherme Palmeira. Diário Oficial da União, Brasília-DF, 18 abr. 2008. Disponível em: <http://www.tcu.gov.br>. Acesso em: out. 2008.

BRASIL. Tribunal de Contas da União. Acórdão n ${ }^{\circ}$ 705, de 25 de abril de 2007. Plenário. Solicitação formulada pelo grupo especial de trabalho em execução penal do Ministério Público do Estado do Espírito Santo. Fiscalização em termo de parceria firmado pelo Governo do Estado do Espírito Santo e entidade do Terceiro setor. Solicitante não incluso entre aqueles legitimados para requerer trabalhos da espécie. Ausência de indícios de irregularidades. Negado conhecimento. Relator: Benjamin Zymler. Diário Oficial da União, Brasília-DF, 27 abr. 2007. Disponível em: $<$ http://www.tcu.gov.br $>$. Acesso em: out. 2008.

BRASIL. Tribunal de Contas da União. Acórdão n ${ }^{0}$ 707, 23 de abril de 2008. Plenário. Solicitação do Congresso Nacional para realização de auditoria em convênios celebrados pela Superintendência Regional do Instituto Nacional de Colonização e Reforma Agrária no Maranhão. Conhecimento. Trabalhos já efetuados por esta Corte. Comunicação. Relator: André Luís de Carvalho. Diário Oficial da União, Brasília-DF, 25 abr. 2008. Disponível em: <http://www.tcu.gov.br>. Acesso em: out. 2008. 
BRASIL. Tribunal de Contas da União. Acórdão n ${ }^{\circ}$ 713, de 23 de abril de 2008. Plenário. Tomada de contas especial. Pagamento de diárias e passagens para exercício de cargos em caráter permanente. Boa-fé. Abertura de prazo para recolhimento do débito. Novos elementos de defesa apresentados por um dos responsáveis. Quitação para um dos responsáveis. Relator: Ubiratan Aguiar. Diário Oficial da União, Brasília-DF, 25 abr. 2008. Disponível em: <http://www.tcu.gov.br>. Acesso em: out. 2008.

BRASIL. Tribunal de Contas da União. Acórdão $n^{0} 715,11$ de março de 2008. Primeira Câmara. Representação. Município de Itacuruba-PE. Não comprovação da boa e regular aplicação de recursos federais repassados. Débito. Conversão em Tomada de Contas Especial. Citação. Identificação de Indícios de Irregularidades que ensejam a audiência dos responsáveis. Relator: Valmir Campelo. Diário Oficial da União, Brasília-DF, 14 mar. 2008. Disponível em: <http://www.tcu.gov.br>. Acesso em: out. 2008.

BRASIL. Tribunal de Contas da União. Acórdão $\mathrm{n}^{\circ}$ 788, de 24 de maio de 2006. Plenário. Representação de unidade técnica. Fiscalização de orientação centralizada em órgãos e entidades federais repassadores de recursos mediante transferências voluntárias. Consolidação dos resultados. Deteç̧ão de fragilidades de controle. Determinação. Identificadas fragilidades nas sistemáticas de controle dos recursos federais repassados mediante transferências voluntárias, impõe-se o estabelecimento de determinações com vistas a buscar-se a sua correção. Relator: Augusto Sherman Cavalcanti. Diário Oficial da União, Brasília-DF, 26 mai. 2006. Disponível em: $<$ http://www.tcu.gov.br>. Acesso em: out. 2008.

BRASIL. Tribunal de Contas da União. Acórdão n 936, de 23 de maio de 2007. Plenário. Auditoria. Verificação de impropriedade e irregularidades em convênios. Audiência. Acolhimento das razões de justificativa de uma Responsável, rejeição das de outro. Aplicação de multa neste. Determinações. Arquivamento. Relator: Benjamin Zymler. Diário Oficial da União, Brasília-DF, 28 mai. 2007. Disponível em: $<$ http://www.tcu.gov.br>. Acesso em: out. 2008.

BRASIL. Tribunal de Contas da União. Acórdão $n^{0}$ 2067, de 18 de novembro de 2008. Plenário. Auditoria Operacional. Auditoria de natureza operacional. Programa resíduos sólidos urbanos. Deteç̧ão de falhas. Determinações e recomendações. Relator: Ubiratan Aguiar. Diário Oficial da União, Brasília-DF, 19 set. 2008. Disponível em: <http://www.tcu.gov.br>. Acesso em: nov. 2008.

BRASIL. Tribunal de Contas da União. Convênios e outros repasses. 2.ed. Brasília : Secretaria-Geral de Controle Externo, 2008. Disponível em: $<$ http://portal2.tcu.gov.br/portal/page/portal/TCU/comunidades/biblioteca_tcu/biblioteca_digital/Conv enios_e_outros_repasses_2a_Edicao.pdf $>$. Acesso em: out. 2008.

BRASIL. Tribunal de Contas da União. Decisão $n^{0}$ 592, de 02 de setembro de 1998. Administrativo. Projeto de Instrução Normativa. Acréscimo de dispositivo à Instrução Normativa TCU n ${ }^{0} 12 / 96$, que estabelece normas de organização e apresentação de tomadas e prestações de contas e rol de responsáveis. Aprovação. Conhecimento. Arquivamento. -Entendimento de que as contas anuais das Organizações Sociais são submetidas a julgamento pelo Tribunal. -Organizações Sociais. Contrato de Gestão. Competência do TCU. Considerações. Relator: Benjamin Zymler. Boletim do TCU, n. 63, Brasília-DF, 1998. Disponível em: <http://www.tcu.gov.br>. Acesso em: out. 2008.

BRASIL. Tribunal de Contas da União. Decisão no 649, de 19 de junho de 2002. Plenário. Auditoria de natureza operacional. Recomendações. Determinação. Juntada de cópia do relatório de auditoria ao processo que trata da Política Nacional de Medicamentos e remessa aos órgãos e entidades competentes. Conversão dos autos em acompanhamento para que a $4^{\text {a }}$ Secex monitore a implementação das recomendações. Relator: Marcos Vinicios Vilaça. Diário Oficial da União, Brasília-DF, 08 jul. 2002. Disponível em: <http://www.tcu.gov.br>. Acesso em: out. 2008.

BRASIL. Tribunal de Contas da União. Decisão no 931, de 15 de dezembro de 1999. Administrativo. Estudos realizados por Grupo de Trabalho com a finalidade de examinar o alcance das disposições da Lei das Organizações da Sociedade Civil de Interesse Público - Lei $n^{\circ}$ 9.790/99 - nas atividades de controle a cargo do TCU. Projeto de Instrução Normativa. Alteração de dispositivos da Instrução Normativa $\mathrm{n}^{\circ}$ 12/96. Aprovação. Determinação. Encaminhamento do estudo ao Conselho da Comunidade Solidária para o aperfeiçoamento do Decreto $\mathrm{n}^{\circ} 3.100 / 99$. Relator: Marcos Vilaça. 
Boletim do TCU, n. 78, Brasília-DF, 1999. Disponível em: <http://www.tcu.gov.br>. Acesso em: out. 2008.

BRASIL. Tribunal de Contas da União. Decisão Normativa $n^{0}$ 85, de 19 de setembro de 2007. Define, para 2008, as unidades jurisdicionadas cujos responsáveis devem apresentar contas relativas ao exercício de 2007, especificando as organizadas de forma consolidada e agregada; os critérios de risco, materialidade e relevância para organização dos processos de forma simplificada; o escalonamento dos prazos de apresentação; o detalhamento do conteúdo das peças que compõem os processos de contas; e critérios de aplicabilidade e orientações para a remessa de contas por meio informatizado; na forma estabelecida pelos artigos $4^{\circ}, 7^{\circ}, 8^{\circ}, 14,15$ e 19 da Instrução Normativa TCU 47, de 27 de outubro de 2004. Diário Oficial da União, Brasília-DF, 24 set. 2007. Disponível em: <http://www.tcu.gov.br>. Acesso em: out. 2008.

BRASIL. Tribunal de Contas da União. Decisão Normativa $n^{\circ}$ 94, 03 de dezembro de 2008. Define, para 2009, as unidades jurisdicionadas cujos responsáveis devem apresentar processos de contas relativas ao exercício de 2008, especificando a forma, os prazos e os conteúdos dos demonstrativos que os comporão, nos termos dos artigos $4^{\circ}, 6^{\circ}, 13$ e 14 da Instrução Normativa TCU n n 57, de 27 de agosto de 2008. Diário Oficial da União, Brasília-DF, 03 dez. 2008. Disponível em: $<$ http://www.cgu.gov.br/Legislacao/Arquivos/DecisoesNormativas/DN_TCU_94_08.pdf $>$. Acesso em: out. 2008.

BRASIL. Tribunal de Contas da União. Instrução Normativa $n^{\circ}$ 57, 27 de agosto de 2008. Estabelece normas de organização e apresentação dos relatórios de gestão e dos processos de contas da administração pública federal. Diário Oficial da União, Brasília-DF, 27 ago. 2008. Disponível em: $<$ http://www.cgu.gov.br/Legislacao/Arquivos/InstrucoesNormativas/IN_TCU_57_2008.pdf $>$. Acesso em: out. 2008.

BRASIL. Tribunal de Contas da União. Manual de auditoria de natureza operacional. Brasília: TCU, Coordenadoria de Fiscalização e Controle, 2000. Disponível em: $<$ http://www.control.rn.gov.br/pdf/trabalhos\%20e\%20artigos/manual\%20de\%20auditoria.pdf $>$. Acesso em: out. 2008.

BRASIL. Tribunal de Contas da União. Regimento Interno no Tribunal de Contas da União RITCU. Boletim do Tribunal de Contas da União, Brasília, ano 40, n. 1, fev. 2007. Disponível em: $<$ http://portal2.tcu.gov.br/portal/page/portal/TCU/normativos/BTCU_ESPECIAL_01_DE_13_02_200 7.pdf $>$. Acesso em: out. 2008.

BRASIL. Tribunal de Contas da União. Relatório e pareceres prévios sobre as contas do Governo da República: exercício de 2006. Brasília-DF: TCU, 2007. Disponível em: $<$ http://portal2.tcu.gov.br/portal/page/portal/TCU/comunidades/contas/contas_governo/CONTAS_AR QUIVOS_2006/Textos/CG_2006_Relatorio.pdf>. Acesso em: out. 2009.

BRASIL. Tribunal de Contas da União. Revista do Tribunal de Contas da União, Brasília, n. 50, p. 51-78, 1991.

BRASIL. Tribunal de Contas da União. Súmula nº 088, de 16 de dezembro de 1976. Diário Oficial da União, Brasília-DF, 16 dez. 1976. Disponível em: <http://www.tcu.gov.br>. Acesso em: out. 2008.

BRASIL. Tribunal de Contas do Estado de Pernambuco. Resolução ${ }^{\circ}$ 0020, de 21 de setembro de 2005. Dispõe sobre os institutos da Organização Social - OS e da Organização da Sociedade Civil de Interesse Público - OSCIP, regulamenta a prestação de contas dessas entidades ao Poder Público e dá outras providências. Relator: Carlos Porto. Diário Oficial do Estado, $n^{\circ} 109$, p. 2, Recife, 28 set. 2005. Disponível em: <http://www.tce.pe.gov.br/resolucao-virtual/2005/r202005.htm>. Acesso em: set. 2008.

BRASIL. Tribunal de Contas do Estado de São Paulo. Instrução Normativa no 01/2008 - área estadual. Disponível em: $<\mathrm{http}: / /$ www.tce.sp.gov.br/legislacao/instrucoes/instrucoes_n_1_2008_area_estadual.pdf $>$. Acesso em: set. 2008. 
BRASIL. Tribunal de Contas do Estado de São Paulo. Instrução Normativa no 01/2008 - área estadual. Disponível em: $<$ http://www.tce.sp.gov.br/legislacao/instrucoes/instrucoes_n_1_2008_area_estadual.pdf $>$. Acesso em: set. 2008.

BRASIL. Tribunal de Contas do Estado de São Paulo. Instrução Normativa $n^{0}$ 02/2008 - área municipal. Disponível em: $<$ http://www.tce.sp.gov.br/legislacao/instrucoes/instrucoes_n_2_2008_area_municipal.pdf $>$. Acesso em: set. 2008.

BRASIL. Tribunal de Contas do Estado de São Paulo. Legislação. Deliberação. Processo TCA 29.268/026/05. Disponível em: <http://www.tce.sp.gov.br/legislacao/sumulas/delibera-2005-12-15sumulas.shtm>. Acesso em: set. 2008.

BRASIL. Tribunal de Contas do Estado de São Paulo. Lei Complementar $n^{\circ} 709$, de 14 de janeiro de 1993. Dispõe sobre a Lei Orgânica do Tribunal de Contas do Estado. Diário Oficial do Estado, São Paulo, 15 jan. 1993. Disponível em: <http://www.tce.sp.gov.br/legislacao/lei-organica/lc709.pdf>. Acesso em: set. 2008.

BRASIL. Tribunal de Contas do Estado de São Paulo. Manual básico: repasses públicos ao Terceiro setor. 2007. Disponível em: <http://www.tce.sp.gov.br/arquivos/manuaisbasicos/2007_repasses_terceiro_setor.pdf $>$. Acesso em: set. 2008.

BRASIL. Tribunal de Contas do Município de São Paulo. Instrução nº 01, de 16 de outubro de 1985. Diário Oficial do Estado, p. 57, São Paulo, 26 out. 1985. Disponível em: $<$ http://www.tcm.sp.gov.br/legislacao/resol/IN_0185.HTM>. Acesso em: set. 2008.

BRASIL. Tribunal de Justiça do Estado de São Paulo. Apelação cível com revisão no 8573295400-SP. Exibição de livros e documentos - Organização da sociedade civil de interesse público - OSCIP - Lei Federal 9790/99 e CF art. 70 § único - Prestação de contas - Norma municipal de igual previsão em sua esfera - Legitimidade - Recurso provido. Relator: Magalhães Coelho. São Paulo, 10 de fevereiro de 2009. Lex: jurisprudência do TJE-SP, São Paulo, 13 mar. 2009.

BRITTO, Carlos A. O regime constitucional dos Tribunais de Contas. Revista Diálogo Jurídico, Salvador, v. 1, n. 9, dez. 2001. 12 p. Disponível em: <http://www.direitopublico.com.br $>$. Acesso em: out. 2008.

BRUNET, Karina. Crise do Estado: participação e solidariedade. Revista de Informação Legislativa, Brasília, ano 38, n. 152, p. 205-214, out./dez. 2001.

BULOS, Uadi L. Constituição Federal anotada. 7. ed. São Paulo: Saraiva, 2007.

CANOTILHO, Jose J. G. Brancosos e interconstitucionalidade: itinerários dos discursos sobre a historicidade constitucional. Coimbra: Almedina, 2006.

CARVALHO, Carlos E. V. Os novos caminhos do Direito administrativo no contexto evolutivo do Estado de Direito. In: PEREIRA, Cláudia F. O. (Org.); et al. O Novo Direito Administrativo Brasileiro: o Estado, as Agências e o Terceiro setor. Belo Horizonte: Fórum, 2003.

CASSESE, Sabino. La arena pública: nuevos paradigmas para el Estado. In: La crisis del Estado. Buenos Aires: Abeledo-Perrot, 2003. p. 101-160.

CASTRO, Rodrigo P. A. Sistema de controle interno: uma perspectiva do modelo de gestão pública gerencial. Belo Horizonte: Fórum, 2007.

CASTRO, Rodrigo P. A. O sistema de controle interno e as entidades do Terceiro setor: perspectiva gerencial e o princípio da eficiência. In: OLIVEIRA, Gustavo H. J. (Coord.); et al. Direito do Terceiro Setor. Belo Horizonte: Fórum, 2008.

CHAVES, Francisco E. C. Controle externo da gestão pública: a fiscalização pelo legislativo e pelos Tribunais de Contas: teoria e jurisprudência. Rio de Janeiro: Impetus, 2007.

CHEVALLIER, Jacques. L'État de droit. Paris: Montchrestien, 2003. 
CHEVALLIER, Jacques. L'État post-moderne. 2.ed. Paris: LGDJ, 2004.

CICONELLO, Alexandre. O conceito legal de público no Terceiro setor. In: SZAZI, Eduardo (Org.); et al. Terceiro setor: temas polêmicos 1. São Paulo: Peirópolis, 2004.

CITADINI, Antonio R. O Controle Externo da Administração Pública. São Paulo: Max Limonad, 1995.

COELHO, Simone C. T. Terceiro setor: um estudo comparado entre Brasil e Estados Unidos. São Paulo: SENAC, 2000.

CONTI, José M. Direito financeiro na Constituição de 1988. São Paulo: Oliveira Mendes, 1998.

COSTALDELLO, Ângela C. Entidades privadas que recebem recursos públicos: necessidade de licitar. Boletim Informativo de Licitações e Contratos, Doutrina/Parecer, Curitiba, n. 82, dez. 2000.

CRETELLA JÚNIOR, José. Comentários à Constituição brasileira de 1988. Rio de Janeiro: Forense Universitária, 1997.

DECOMAIN, Pedro R. Tribunais de Contas no Brasil. São Paulo: Dialética, 2006.

DECOMAIN, Pedro R. Improbidade administrativa. São Paulo: Dialética, 2007.

DI PIETRO, Maria S. Z. (Coord.); et al. Temas polêmicos sobre licitações e contratos. 5.ed. São Paulo: Malheiros, 2006.

DI PIETRO, Maria S. Z. Parcerias na Administração pública: concessão, permissão, franquia, terceirização, parceria público-privada e outras formas. 6.ed. São Paulo: Atlas, 2008.

DIAS, Maria Tereza F. Direito administrativo pós-moderno. Belo Horizonte: Mandamentos, 2003.

DIAS, Maria Tereza F. Terceiro setor e Estado: legitimidade e regulação: por um novo marco jurídico. Belo Horizonte: Fórum, 2008a.

DIAS, Maria Tereza F. O exercício do papel regulador do Tribunal de Contas da União sobre as parcerias da Administração pública com as entidades do Terceiro setor na execução de Políticas públicas. In: CONGRESSO NACIONAL DO CONPEDI, 17., Brasília, DF, 2008. Anais eletrônicos. Brasília, DF, 2008b. p. 3456-3486. Disponível em: $<$ http://www.conpedi.org/manaus/arquivos/anais/brasilia/10_598.pdf >. Acesso em: 28 jul. 2009.

DINIZ, Gustavo S. Direito das fundações privadas. 2.ed. Porto Alegre: Síntese, 2003.

DIREITO, Carlos Alberto M. Reforma administrativa: a emenda n. 19/98. Revista de Direito Administrativo, Rio de Janeiro, n. 213, p. 133-139, jul./set. 1998.

DOMINGUES, Carlos V. O controle externo e novos modelos de gestão de serviços públicos: as organizações sociais. Salvador: TCE-BA, 2000. Disponível em: <http://www.tce.ba.gov.br $>$. Acesso em: 22 maio 2009.

DROMI, Roberto. Derecho administrativo. 5.ed. Buenos Aires: Ciudad Argentina, 1996.

DROMI, Roberto. Modernización del control público. Madrid: Hispania Libros, 2005.

ESTORNINHO, Maria J. A fuga para o Direito privado: contributo para o estudo da actividade de Direito privado da Administração pública. Coimbra: Almedina,1996.

FALCÃO, Joaquim. Democracia, Direito e Terceiro setor. Rio de Janeiro: Fundação Getúlio Vargas, 2004.

FERNANDES, Jorge U. J. Tomada de contas especial: processos e procedimento nos Tribunais de Contas e na Administração Pública. 3.ed. Belo Horizonte: Fórum, 2005a.

FERNANDES, Jorge U. J. Tribunais de Contas do Brasil: jurisdição e competência. 2.ed. Belo Horizonte: Fórum, 2005 b.

FERRARI, Paola N.; FERRARI, Regina M. M. N. Controle das Organizações Sociais. Belo Horizonte: Fórum, 2007. 
FERREIRA, Pinto. Comentários à Constituição brasileira. Arts. 54 a 91. 3.vol. São Paulo: Saraiva, 1992.

FERREIRA, Sérgio A. Uma visão crítica das organizações sociais. Revista Trimestral de Direito Público, n. 25, p. 33-42., 1999.

FREITAS, Juarez. Regime peculiar das organizações sociais e o indispensável aperfeiçoamento do modelo federal. Revista de Direito Administrativo, Rio de Janeiro, n. 214, p. 99-106, out./dez. 1998.

FREITAS, Juarez. O controle dos atos administrativos e os princípios fundamentais. 3.ed., rev. ampl. São Paulo: Malheiros, 2004.

FURTADO, Lucas R. Curso de Direito Administrativo. Belo Horizonte: Fórum, 2007.

GABARDO, Emerson. Princípio constitucional da eficiência administrativa. São Paulo: Dialética, 2002.

GAETANI, Francisco. O recorrente apelo das reformas gerenciais: uma breve comparação. Revista do Serviço Público, Brasília, ano 54, n. 4, p. 21-39, Out./Dez. 2003. Disponível em: $<$ http://www.enap.gov.br/index.php?option=com_docman\&task $=$ doc_view\&gid=2617 $>$. Acesso em: jul. 2009.

GASPARINI, Diógenes. Direito administrativo. 7.ed. São Paulo: Saraiva, 2002.

GAUDIN, Jean-Pierre. Gouverner par contrat: l'action publique em question. Paris: Presses de Sciences Politiques, 1999.

GIACOMONI, James. Orçamento público. 13.ed. rev. ampl. São Paulo: Atlas, 2005.

GIANNINI, Massimo S. Diritto amministrativo. 3.ed. Milão: Giuffre, 1993. vol. I.

GONÇALVES, Pedro. Entidades privadas com poderes públicos: o exercício de poderes públicos de autoridade por entidades privadas com funções administrativas. Coimbra: Almedina, 2005.

GOUlART, Karine B. As organizações sociais. Revista da Procuradoria Geral do INSS, Brasília, vol. 8, n. 4, p. 17-36, jan./mar. 2002.

GUERRA, Evandro M. Os controles externo e interno da Administração pública. 2.ed. rev. e ampl. Belo Horizonte: Fórum, 2005.

GUERRA, Luiz A.; MONTANHEIRO, Carmen D.; TAVOLARO, Luiz A.;. Limites à atuação do Tribunal de Contas da União - convênio - repasse de recursos da União - inconstitucionalidade do § $1^{\circ}$, do art. 254, do RITCU - risco de decisões díspares e inexequíveis - questionamento Judicial da decisão. In: ALVIM, Arruda; ALVIM, Eduardo Arruda; TAVOLARO, Luiz A. (Coord.); et al. Licitações e contratos administrativos: uma visão atual à luz dos Tribunais de Contas. Curitiba: Juruá, 2006. p. 327-340.

IBGE. As fundações privadas e associações sem fins lucrativos no Brasil 2005. Rio de Janeiro: IBGE, 2008. (Coleção Estudos e pesquisas. Informação econômica, n. 8). Disponível em: $<$ http://www.ibge.gov.br/home/estatistica/economia/fasfil/2005/>. Acesso em: jul. 2009.

JUSTEN FILHO, Marçal. Curso de Direito administrativo. 3.ed. rev. atual. São Paulo: Saraiva, 2008.

LENZA, Pedro. Direito Constitucional Esquematizado. 10.ed. rev. atual. ampl. São Paulo: Método, 2006.

MACHADO, Regina Helena. Reforma do Estado ou reforma da Constituição? Rio de Janeiro: Lumens Júris, 2001.

MAGAlHÃES, Antonio Silvio. O controle externo da Administração pública pelo Tribunal de Contas. 2005. 279 f. Tese (Doutorado em Direito do Estado) - Faculdade de Direito, Universidade de São Paulo, São Paulo, 2005.

MÂNICA, Fernando B. Terceiro setor e imunidade tributária: teoria e prática. Belo Horizonte: 
Fórum, 2005.

MÂNICA, Fernando B. Panorama histórico-legislativo do Terceiro setor no Brasil: do conceito de Terceiro setor à lei das OSCIP. In: OLIVEIRA, Gustavo H. J. (Coord.); et al. Terceiro setor, empresas e Estado: novas fronteiras entre o público e o privado. Belo Horizonte: Fórum, 2007.

MÂNICA, Fernando B. Participação privada na prestação de serviços públicos de saúde. 2009. 306 f. Tese (Doutorado em Direito Administrativo) - Faculdade de Direito, Universidade de São Paulo, São Paulo, 2009.

MARQUES NETO, Floriano P. A. Público e privado no setor de saúde. Revista de Direito Público da Economia, Belo Horizonte, ano 3, n. 9, p. 105-154, jan./mar. 2005.

MEDAUAR, Odete. Controle da Administração Pública pelo Tribunal de Contas. Revista de Informação Legislativa, Brasília, ano 27, n. 108, p. 101-126, out./dez. 1990.

MEDAUAR, Odete. Controle da Administração Pública. São Paulo: Revista dos Tribunais, 1993.

MEDAUAR, Odete. Convênios e consórcios administrativos. Boletim de Direito Administrativo, n. 8, p. 451-461, 1995.

MEDAUAR, Odete. Regulação e autoregulação. Revista de Direito Administrativo, Rio de Janeiro, n. 228, p. 123-128, abr./jun. 2002.

MEDAUAR, Odete. O Direito Administrativo em Evolução. 2.ed. rev. atual. e ampl. São Paulo: Revista dos Tribunais, 2003.

MEDAUAR, Odete. Direito Administrativo Moderno. 11.ed. São Paulo: Revista dos Tribunais, 2007a.

MEDAUAR, Odete. Prefácio. In: OLIVEIRA, Gustavo H. J. (Coord.); et al. Terceiro setor, empresas e Estado: novas fronteiras entre o público e o privado. Belo Horizonte: Fórum, 2007b.

MEDAUAR, Odete. Constituição de 1988: catalisadora da evolução do Direito Administrativo? Revista do Advogado, ano 27, n. 99, p. 100-107, set. 2008.

MELLO, Célia C. O fomento da Administração pública. Belo Horizonte: Del Rey, 2003.

MELLO, Celso A. B. Curso de Direito administrativo. 25.ed. rev. atual. São Paulo: Malheiros, 2008.

MILESKI, Helio S. O controle da gestão pública. São Paulo: Revista dos Tribunais, 2003.

MODESTO, Paulo. Reforma do marco legal do Terceiro setor no Brasil. Revista de Direito Administrativo, Rio de Janeiro, n. 214, p. 55-68, out./dez. 1998. Disponível em: $<$ http://www.bresserpereira.org.br/Terceiros/Autores/Modesto,Paulo/terceirosetorreforma.PDF>.

Acesso em: set. 2009.

MODESTO, Paulo. Reforma administrativa e marco legal das organizações sociais no Brasil. Jus Navigandi, Teresina, ano 3, n. 30, abr. 1999. Disponível em: $<$ http://jus2.uol.com.br/doutrina/texto.asp?id=473>. Acesso em: mar. 2008.

MONTEIRO, Vera C. C. A caracterização do contrato de concessão após a edição da Lei 11.079/2004. 2009. 226 f. Tese (Doutorado em Direito Administrativo) - Faculdade de Direito, Universidade de São Paulo, São Paulo, 2009.

MORAES, Sílvio F. Controle externo: estudos e casos concretos. Belo Horizonte: Fórum, 2005.

MOREIRA NETO, Diogo F. Coordenação gerencial na Administração pública: Administração pública e autonomia gerencial. Contrato de gestão. Organizações sociais. A gestão associada de serviços públicos: consórcios e convênios de cooperação. Revista de Direito Administrativo, Rio de Janeiro, n. 214, p. 35-53, out./dez. 1998.

MOREIRA NETO, Diogo F. Mutações do Direito Administrativo. 2.ed. Rio de Janeiro: Renovar, 2001.

MOREIRA NETO, Diogo F. Novos institutos consensuais da ação administrativa. Revista de Direito 
Administrativo, Rio de Janeiro, n. 231, p. 129-156, jan.-mar. 2003.

MOREIRA, Egon B. Terceiro setor da Administração pública. Organizações sociais. Contrato de gestão. Revista de Direito Administrativo, Rio de Janeiro, n. 227, p. 309-320, jan./mar. 2002.

MOREIRA, Egon B. Organizações sociais, organizações da sociedade civil de interesse público e seus "vínculos contratuais" com o Estado. Fórum Administrativo - Direito Público - FA, Belo Horizonte, ano 6, n. 62, p. 7085-7092, abr. 2006.

MOREIRA, Vital. Auto-regulação profissional e Administração pública. Coimbra: Almedina, 1997.

NUNES, Andréa. Terceiro setor: controle e fiscalização. 2.ed. São Paulo: Método, 2006.

OLIVEIRA, Gustavo H. J. Estado contratual, direito ao desenvolvimento e parceria público-privada. In: TALAMINI, Eduardo (Coord.); et al. Parceria público-privada: uma abordagem multidisciplinar. São Paulo: RT, 2005a. p. 83-119.

OLIVEIRA, Gustavo H. J. Parceria público-privada e Direito ao desenvolvimento: uma abordagem necessária. Revista Eletrônica de Direito Administrativo Econômico, Salvador, n. 3, p. 1-28, ago./out. 2005b. Disponível em: <http://www.direitodoestado.com/revista/REDAE-3-AGOSTO-2005GUSTAVO\%20JUSTINO.pdf>. Acesso em: 28 jul. 2009.

OLIVEIRA, Gustavo H. J. Direito do Terceiro Setor. Revista de Direito do Terceiro Setor, Belo Horizonte, ano 1, n. 1, p. 11-38, jan./jun. 2007a.

OLIVEIRA, Gustavo H. J. (Coord.); et al. Terceiro setor, empresas e Estado: novas fronteiras entre o público e o privado. Belo Horizonte: Fórum, 2007b.

OLIVEIRA, Gustavo H. J. Constitucionalidade da Lei Federal n 9.637/98, das Organizações Sociais: comentários à medida cautelar da Adin n. 1.923-DF, do Supremo Tribunal Federal. Revista de Direito do Terceiro Setor, Belo Horizonte, ano 1, n. 2, p. 177-210, jul./dez. 2007c.

OLIVEIRA, Gustavo H. J. Estatuto jurídico do Terceiro setor e desenvolvimento: conectividade essencial ao fortalecimento da cidadania à luz dos 20 anos da constituição de 1988. In: CONGRESSO NACIONAL DO CONPEDI, 17., Brasília, DF, 2008a. Anais eletrônicos. Brasília, DF, 2008a. p. 1084-1109. Disponível em: <http://www.conpedi.org/manaus/arquivos/anais/brasilia/10_169.pdf $>$. Acesso em: 28 jul. 2009.

OLIVEIRA, Gustavo H. J. Governança pública e parcerias do Estado: a relevância dos acordos administrativos para a nova gestão pública. Revista Âmbito Jurídico, Rio Grande, n. 58, out. 2008b. Disponível em: $\quad<$ http://www.ambitojuridico.com.br/site/index.php?_link=revista_artigos_leitura\&artigo_id=5177>. Acesso em: 28 jul. 2009.

OLIVEIRA, Gustavo H. J. Contrato de Gestão. São Paulo: Revista dos Tribunais, 2008c.

OLIVEIRA, Gustavo H. J. OSCIPS e licitação: ilegalidade do Decreto n. 5.504, de 05.08.05 - Parecer. Revista Eletrônica sobre a Reforma do Estado, Salvador, Instituto Brasileiro de Direito Público, n. 12, dez./fev. 2008d. Disponível em: <http://www.direitodoestado.com/revista/RERE-12-DEZEMBRO2007-GUSTAVO\%20JUSTINO.pdf> Acesso em: 10 out. 2008.

OLIVEIRA, Gustavo H. J. (Coord.); et al. Direito do Terceiro Setor. Belo Horizonte: Fórum, 2008e.

OLIVEIRA, José R. P. Improbidade administrativa e Terceiro setor. In: ADRI, Renata P.; PIRES, Luis M. F.; ZOCKUN, Maurício (Coords.); et al. Corrupção, ética e moralidade administrativa. Belo Horizonte: Fórum, 2008. p. 161-192.

OLIVEIRA, Regis F. Curso de Direito financeiro. 2.ed. São Paulo: Revista dos Tribunais, 2008.

PAES, José E. S. Fundações, associações e entidades de interesse social: aspectos jurídicos, administrativos, contábeis, trabalhistas e tributários. 6.ed. Brasília: Brasília Jurídica, 2006.

PELEGRINI, Márcia. Terceiro setor: gestão privada de recursos públicos. Revista de Direito do Terceiro Setor, Belo Horizonte, ano 1, n. 2, p. 51-71, jul./dez. 2008. 
PELEGRINI, Márcia. A competência sancionatória do Tribunal de Contas no exercício da função controladora: contornos constitucionais. 2008. 331 f. Tese (Doutorado em Direito do Estado) Departamento de Pós-Graduação em Direito, Pontifícia Universidade Católica de São Paulo, São Paulo, 2008. Disponível em: $<$ http://www.sapientia.pucsp.br//tde_busca/arquivo.php?codArquivo=7957>. Acesso em: mar. 2009.

PEREIRA, Luiz C. B.; et al. (Orgs.); et al. Sociedade e Estado em transformação. São Paulo: UNESP, 1999.

PEREIRA, Cláudia F. O. Os Tribunais de Contas e o Terceiro setor: aspectos polêmicos do controle. In: OLIVEIRA, Gustavo H. J. (Coord.); et al. Terceiro setor, empresas e Estado: novas fronteiras entre o público e o privado. Belo Horizonte: Fórum, 2007.

PIRES, Maria C. S. Terceiro setor e organizações sociais. Boletim de Direito Administrativo, ano 15, n. 4, p. 245-255, abr. 1999.

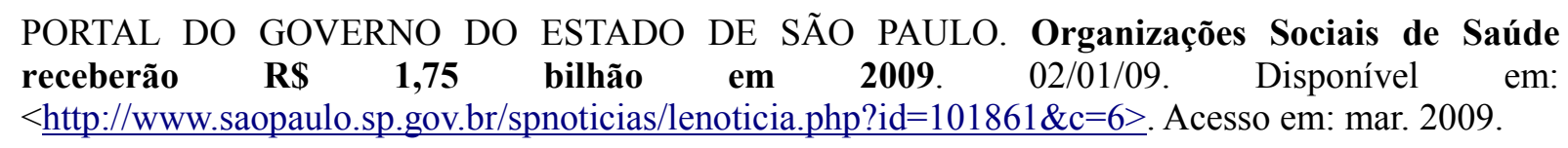

PRATS I CATALÀ, Joan. La construcción social de la gobernanza. In: ; VIDAL BELTRÁN, José María (Coords.); et al. Gobernanza: diálogo europeu-iberoamericano sobre el buen gobierno. Madrid: Editorial Constitución y Leyes; Colex, 2005. p. 21-78.

QUIRÓS, Mario M. Responsabilização pelo controle de resultados. In: BRESSER-PEREIRA, Luiz C. B.; GRAU, Nuria C. (Coords); et al. Responsabilização na Administração pública: coletânea. São Paulo: CLAD/Fundap, 2006. p. 165-216.

REGULES, Luis E. P. Terceiro setor: regime jurídico das OSCIPs. São Paulo: Método, 2006.

REGULES, Luis E. P. Notas sobre os princípios constitucionais da Administração pública e as organizações do Terceiro setor. In: BARROSO, Darlan; et al. Direito Constitucional: temas atuais. São Paulo: Método, 2007.

RIBEIRO, Rochelle P. O Terceiro setor no contexto da democracia e da reforma Administrativa do aparelho do Estado. In PEREIRA, Cláudia F. O. (Org.); et al. O Novo Direito Administrativo Brasileiro: o Estado, as Agências e o Terceiro setor. Belo Horizonte: Fórum, 2003.

ROCHA, Sílvio L. F. Terceiro Setor. São Paulo: Malheiros, 2003. (Coleção Temas de Direito administrativo, n. 7.)

ROSANVALLON, Pierre. La crise de l'État-providence. 2.ed. Paris: Du Seuil, 1981.

SALINAS, Natasha S. C. Avaliação legislativa no Brasil: um estudo de caso sobre as normas de controle das transferências voluntárias de recursos públicos para entidades do terceiro setor. 2008. 256 f. Dissertação (Mestrado em Direito) - Faculdade de Direito, Universidade de São Paulo, São Paulo, 2008.

SAMARCO, Christiane; OTTA, Lu Aiko. Portal fiscalizará R\$ 35 bi em convênios. O Estado de São Paulo, São Paulo, 20 out. 2008. Nacional, p. A4. Disponível em: $<$ http://www.serpro.gov.br/serpronamidia/2008/outubro/portal-fiscalizara-r-35-bi-em-convenios $>$.

Acesso em: set. 2009).

SAMPAIO, José A. L. As organizações sociais. Revista de Direito do Estado, ano 2, n. 7, p. 273 287, jul./set. 2007.

SANTO, Ataliba P. E. As organizações sociais e a Reforma administrativa. Revista de Direito Administrativo, Rio de Janeiro, vol. 230, out./dez. 2002.

SANTOS, Jair L. Tribunal de Contas da União \& controles estatal e social da Administração pública. Curitiba: Juruá, 2003. 
SEMER, Márcia M. B. F. Competências constitucionais do Tribunal de Contas. 2000. 147 f. Dissertação (Mestrado em Direito Administrativo) - Faculdade de Direito, Universidade de São Paulo, São Paulo, 2000.

SILVA, José A. Comentário contextual à Constituição. 5.ed. São Paulo: Malheiros, 2008.

SOUSA, Luciano Brandão Alves de. Apreciações sobre o controle externo. Revista de Informação Legislativa, Brasília, ano 43, n. 171, p. 259-264, jul./set. 2006.

SOUZA, Leandro M. Tributação do Terceiro setor no Brasil. São Paulo: Dialética, 2004.

SOUZA, Patrícia C. R. Controle da Administração Pública. In: MOTTA, Carlos P. C. (Coord); et al. Curso prático de Direito administrativo. 2.ed. Belo Horizonte: Del Rey. 2004.

SOUZA, Rodrigo P. Convênios administrativos de delegação de Serviço público de saneamento básico: regime jurídico. 2006. 210 f. Dissertação (Mestrado em Direito do Estado) - Faculdade de Direito, Universidade de São Paulo, São Paulo, 2006.

SUNDFELD, Carlos A. A Administração pública na Era do Direito global. Revista Diálogo Jurídico, Salvador, ano 1, vol. 1, n. 2, maio 2001. Disponível em: $<$ http://www.buscalegis.ufsc.br/revistas/index.php/buscalegis/article/viewFile/31987/31228 $\geq$. Acesso em: 06 de março de 2008.

SCARPINELLA, Vera; SUNDFELD, Carlos Ari. Fundações educacionais e licitação. In: PANTALEÃO, Leonardo (Coord.); et al. Fundações educacionais. São Paulo: Atlas, 2003.

TÁCITO, Caio. O retorno do pêndulo: serviço público e empresa privada: o exemplo brasileiro. Revista Forense, Rio de Janeiro, ano 92, n. 334, p. 11-18, abr./jun. 1996.

TÁCITO, Caio. Transformações do Direito administrativo. Revista de Direito Administrativo, Rio de Janeiro, n. 214, p. 27-34, out./dez. 1998.

TÁCITO, Caio. A reforma do Estado e a modernidade administrativa. Revista de Direito Administrativo, Rio de Janeiro, n. 215, p. 1-7, jan./mar. 1999.

TAVEIRA NETO, Francisco. A evolução da Administração pública e de seus mecanismos de controle na Constituição federal. Revista Zênite de Direito Administrativo e LRF - IDAF, Belo Horizonte, n. 57, p. 791-796, abr. 2006.

TOBA, Marcos M. Novos parâmetros de atuação da Administração pública. 2003. $184 \mathrm{f}$. Tese (Doutorado em Direito Administrativo) - Faculdade de Direito, Universidade de São Paulo, São Paulo, 2003.

TODERO, Domingos R. Dos convênios da Administração pública. 2006. 627 f. Dissertação (Mestrado em Direito) - Faculdade de Direito, Pontifícia Universidade Católica do Rio Grande do Sul, Porto Alegre, $2006 . \quad$ Disponível em: $<$ http://bdjur.stj.gov.br/xmlui/bitstream/handle/2011/9693/Dos_Conv\%c3\%aanios_da_Administra\%c3 \%a7\%c3\%a3o_P\%c3\%bablica.pdf?sequence=1>. Acesso em: jul. 2009.

TORRES, Ricardo L. A legitimidade democrática e o Tribunal de Contas. Cadernos de Direito Constitucional e Ciência Política, São Paulo, v. 1, n. 4, p. 185-198, jul./set. 1993.

TORRES, Silvia F. O princípio da subsidiariedade no Direito público contemporâneo. Rio de Janeiro: Renovar, 2001.

TREZZA, Valéria M. O termo da parceria como instrumento de relação público/privado sem fins lucrativos: o difícil equilíbrio entre flexibilidade e controle. 2007. 198 f. Dissertação (Mestrado em Administração Pública e Governo) - Escola de Administração de Empresas de São Paulo, Fundação Getúlio Vargas, São Paulo, 2007. Disponível em: <http://virtualbib.fgv.br/dspace/handle/10438/2406>. Acesso em: jul. 2009.

VALADÃO, Perpétua I.; CARVALHO, Paulo M. Organizações sociais: processo seletivo para firmar contrato de gestão. In: FIGUEIREDO, Guilherme J. P.; NUZZI NETO, José. Temas de Direito 
Constitucional: estudos em homenagem ao advogado público André Franco Montoro. Rio de Janeiro: Esplanada-IBAP, 2000.

VALLE, Vanice L. Terceiro setor e parcerias com a Administração pública: desafios ao controle das OS e OSCIPs. Revista de Direito do Terceiro Setor, Belo Horizonte, ano 2, n. 4, p. 47-64, jul./dez. 2008.

VIOLIN, Tarso C. Terceiro setor e as parcerias com a Administração pública: uma análise crítica. Belo Horizonte: Fórum, 2006.

WALD, Arnoldo. As novas tendências do Direito administrativo. Revista do Ministério Público, Rio de Janeiro, n. 17, p. 89-103, jan/jun 2003.

ZYMLER, Benjamin. Processo administrativo no Tribunal de Contas da União. In: BRASIL. Tribunal de Contas da União. Prêmio Serzedello Corrêa 1996: monografias vencedoras. Brasília: Instituto Serzedello Corrêa, Serviço de Editoração e Publicações, 1997. p. 139-220. Disponível em: $<$ http://portal2.tcu.gov.br/portal/page/portal/TCU/concursos/premio_serzedello/concursos_anteriores/ monografias_1996.pdf>. Acesso em: jul. 2009.

ZYMLER, Benjamin. Direito Administrativo e Controle. Belo Horizonte: Fórum, 2005. 